\title{
Satellite cells in skeletal muscle atrophy and hypertrophy
}

Citation for published version (APA):

Snijders, T. (2014). Satellite cells in skeletal muscle atrophy and hypertrophy. [Doctoral Thesis, Maastricht University]. Datawyse / Universitaire Pers Maastricht. https://doi.org/10.26481/dis.20141218ts

Document status and date:

Published: 01/01/2014

DOI:

$10.26481 /$ dis.20141218ts

Document Version:

Publisher's PDF, also known as Version of record

\section{Please check the document version of this publication:}

- A submitted manuscript is the version of the article upon submission and before peer-review. There can be important differences between the submitted version and the official published version of record.

People interested in the research are advised to contact the author for the final version of the publication, or visit the DOI to the publisher's website.

- The final author version and the galley proof are versions of the publication after peer review.

- The final published version features the final layout of the paper including the volume, issue and page numbers.

Link to publication

\footnotetext{
General rights rights.

- You may freely distribute the URL identifying the publication in the public portal. please follow below link for the End User Agreement:

www.umlib.nl/taverne-license

Take down policy

If you believe that this document breaches copyright please contact us at:

repository@maastrichtuniversity.nl

providing details and we will investigate your claim.
}

Copyright and moral rights for the publications made accessible in the public portal are retained by the authors and/or other copyright owners and it is a condition of accessing publications that users recognise and abide by the legal requirements associated with these

- Users may download and print one copy of any publication from the public portal for the purpose of private study or research.

- You may not further distribute the material or use it for any profit-making activity or commercial gain

If the publication is distributed under the terms of Article $25 \mathrm{fa}$ of the Dutch Copyright Act, indicated by the "Taverne" license above, 
Satellite cells in skeletal muscle atrophy and hypertrophy

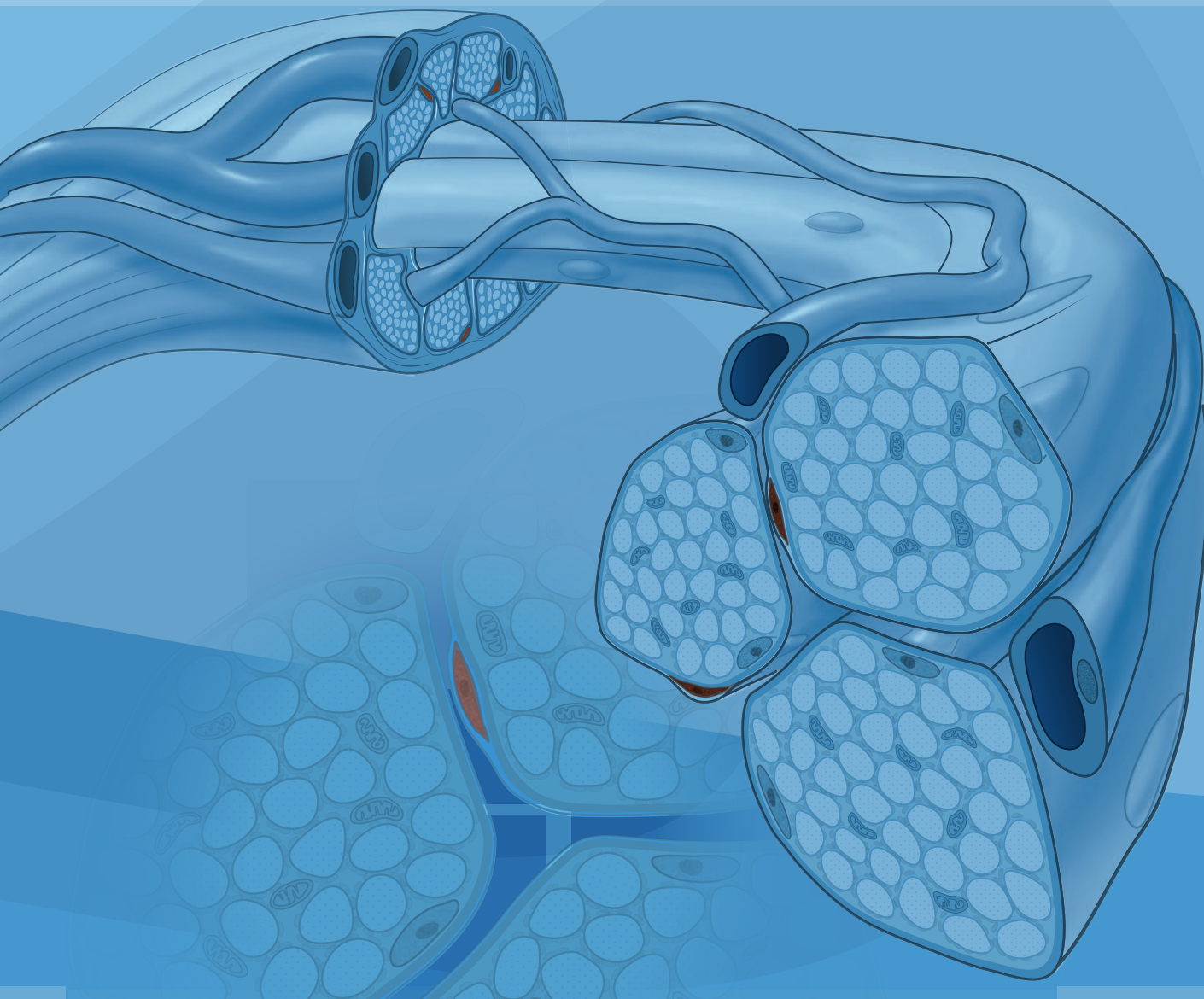

Tim Snijders 


\section{itution}

The work presented in this thesis was performed within NUTRIM, School for Nutrition, Toxicology and Metabolism, which participates in the Graduate School VLAG (Food Technology, Agrobiotechnology, Nutrition and Health Sciences), accredited by the Royal Netherlands Academy of Arts and Sciences.

Cover design: Remko van Deijk

Printed by: Datawyse, Universitaire Pers Maastricht

ISBN 9789461593757

(C) Copyright Tim Snijders, Maastricht 2014

All rights reserved. No part of this thesis may be reproduced or transmitted in any form or by any means, electronic, or mechanical, including photocopying, recording or any information storage or retrieval system, without permission from the author in writing, or when appropriate, from the publishers of the publications. 


\title{
Satellite cells in skeletal muscle atrophy and hypertrophy
}

\author{
DISSERTATION \\ to obtain the degree of Doctor at Maastricht University, \\ on the authority of the Rector Magnificus Prof. dr. L.L.G. Soete \\ in accordance with the decision of the Board of Deans, \\ to be defended in public on Thursday $18^{\text {th }}$ December 2014 , at 12:00 hours
}

by

\section{Tim Snijders}

born in Eindhoven, The Netherlands, 15 April 1983

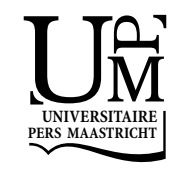




\section{Promotor}

Prof. dr. L.J.C. van Loon

\section{Copromotor}

Dr. L.B. Verdijk

\section{Assessment Committee}

Prof. dr. ir. A.M.W.J. Schols (chair)

Prof. dr. M.A. Bamman (University of Alabama, Birmingham, USA)

Prof. dr. ir. C.P.G.M. de Groot (WUR, Wageningen)

Prof. dr. C.H.C. Dejong

Prof. dr. G.J. van der Vusse 


\section{CONTENTS}

Chapter 1 Introduction: The impact of sarcopenia and exercise training on skeletal muscle satellite cells

Chapter 2 Satellite cells in human skeletal muscle; from birth to old age 25

Chapter 3 Muscle disuse atrophy is not accompanied by changes in skeletal muscle satellite cell content

Chapter 4 A single bout of exercise activates skeletal muscle satellite cells during subsequent overnight recovery

Chapter $5 \quad$ Eccentric exercise increases satellite cell content in type II muscle fibers

Chapter 6 The skeletal muscle satellite cell response to a single bout of resistance type exercise is delayed with aging in men

Chapter 7 Acute dietary protein intake restriction modulates muscle myostatin expression after a single bout of resistance exercise in healthy young men

Chapter 8 Protein ingestion prior to sleep increases muscle mass gain during prolonged resistance type exercise training in young men

Chapter 9 Changes in myonuclear domain size do not precede muscle fiber hypertrophy during prolonged resistance type exercise training in healthy young men

Chapter 10 General discussion

Summary

Samenvatting

Valorization

Dankwoord

Curriculum Vitae 



\section{CHAPTER 1}

\section{General introduction: The impact of sarcopenia and exercise training on skeletal muscle satellite cells}


The primary function of skeletal muscle is to establish locomotion, postural behavior and breathing. In addition, as skeletal muscle comprises $\sim 70 \%$ of the body cell mass, it plays a vital role in glucose, fat, and protein metabolism. Muscle strength and muscle power are largely dependent on muscle mass and, as such, skeletal muscle mass represents a major determinant of functional performance in daily life. However, in clinical conditions rapid skeletal muscle mass loss has been observed as a consequence of neurological dysfunction (e.g. spinal cord injury, multiple scleroses), genetic defects (e.g. Duchene muscular dystrophy, Pompe disease, myotonic muscular dystrophy) or other non-communicable diseases (e.g. cancer cachexia, stroke, chronic obstructive pulmonary disease (COPD)). If left untreated, the loss of muscle mass will result in reduced muscle strength and physical performance, increased fall risk, and in the worst case scenario it can even lead to death.

With aging, there is a more gradual but progressive loss of skeletal muscle mass and function, also referred to as sarcopenia. The loss of muscle mass with aging is unrelated to any disease state, and therefore distinct from cachexia and other muscle wasting conditions associated with diseases like HIV, COPD and stroke. The term sarcopenia was introduced by Rosenberg (40) in an attempt to emphasize the clinical importance of the progressive decline in skeletal muscle tissue as a cause of reduced functional performance in the elderly. The word "sarcopenia" stems from the Greek language and literally translates to poverty (penia) of flesh (sarco). Given the global changes in population demographics and increased life expectancy, sarcopenia is becoming a major health care and socio-economic problem. The detrimental consequences of sarcopenia, i.e., impaired functional performance and physical disability, underline the importance of designing strategies that can effectively delay and/or reverse the loss of skeletal muscle mass with aging. However, before such potential intervention strategies can be defined, the mechanisms underlying age-related muscle atrophy need to be further identified.

Maintenance of skeletal muscle mass is regulated by the balance between muscle protein synthesis and muscle protein breakdown. Although muscle tissue is known to have a relatively slow turnover rate (1-2\% synthesis and breakdown per day), the regenerative capacity of muscle fibers is remarkably high. Beside the balance between muscle protein synthesis and breakdown, long-term muscle mass maintenance depends on a pool of undifferentiated skeletal muscle stem cells, also known as satellite cells. As myonuclei are post-mitotic, satellite cells are the only source to provide new myonuclei. Therefore they are essential for muscle tissue development in early life. In adult muscle, satellite cells are crucial for muscle regeneration, maintenance, and fiber growth. However, the effectiveness through which skeletal muscle regenerates itself appears to reduce with normal aging. It has been hypothesized that a decline in the number of satellite cells or in their ability to properly respond to stimuli may be important in the impaired regenerative and hypertrophic potential typically observed in senescent muscle. As such, loss of satellite cell number and/or function could play a key 
factor in the age-related loss of muscle mass and function. Resistance type exercise represents the most effective intervention strategy to increase skeletal muscle mass and strength, even in the oldest old. However, the exact pathways by which satellite cells facilitate the skeletal muscle adaptive response during post-exercise recovery and with training remain to be elucidated.

In this thesis, the role of skeletal muscle satellite cells is studied in relation to both muscle fiber atrophy and hypertrophy in in vivo human muscle. Specific attention is given to the potential role of satellite cells in the age-related loss of skeletal muscle mass and its relationship to exercise induced muscle fiber hypertrophy, including the role of nutritional intake following exercise in healthy young and elderly individuals.

\section{AGING AND SARCOPENIA}

Population demographics show that the world population aged 60 years and over will triple within 50 years, from 600 million in the year 2000 to more than 2 billion in 2050 (75). Likewise, Dutch population demographics show that by the year 2040 an estimated $26 \%$ of the population will be aged 65 years or older, with one-third being older than 80 years of age (1). This global aging will have a major impact on our healthcare system due to increased morbidity and greater need for hospitalization and/or institutionalization. Good health is essential for elderly people to remain independent and to actively continue to take part in family and community life. One of the factors that play an important role in the ability to maintain a healthy active lifestyle is the preservation of skeletal muscle mass. However, from approximately the fourth decade of life, whole body and regional skeletal muscle mass progressively decline with increasing age, also known as sarcopenia. The decline in muscle mass is most notable in the lower limb muscle groups $(30,41)$, which may explain the apparent loss of mobility with aging. The cross-sectional area of the vastus lateralis muscle has been observed to reduce as much as $40 \%$ between the age of 20 and 80 years (59). Beside the decrease in whole body and regional muscle tissue mass, muscle function is further hampered due to an increase in connective tissue content and fat infiltration $(33,76,84)$.

Skeletal muscle mass is dependent on muscle fiber number and size. Subsequently, the decline in muscle mass with aging can be characterized by a decrease in total fiber number, average fiber size, or both. Only limited data exist on the change in muscle fiber number during healthy aging in human skeletal muscle. Lexell et al. $(58,59)$ were the first to count the number of fibers in human vastus lateralis muscle in healthy young and elderly men. This study reported a $40 \%$ lower number of muscle fibers in healthy elderly compared with healthy young men, suggesting that there is a substantial loss of muscle fibers during normal aging. However, a more recent study by Nilwik et al. (69) calculated that a typical age-related reduction in whole-muscle CSA of 20$25 \%$ can be fully explained by a reduction of muscle fiber size, leaving little to no room for the loss of muscle fibers during aging. Hence, this study concluded that the age- 
related reduction in muscle mass can mainly be attributed to type II muscle fiber atrophy, without a substantial decline in muscle fiber number. In agreement with the data from Nilwik et al (69), the most consistent observation in skeletal muscle tissue of elderly has been the specific atrophy of type II muscle fibers with increasing age $(12,23$, $29,49,50,52,54,56,59,77,93,107)$. In contrast to type I muscle fibers, type II muscle fiber size has been reported to be $10-50 \%$ smaller in healthy elderly compared with healthy young individuals $(12,23,29,49,50,52,54,56,59,77,93,107)$. However, it is worth noting that in most of these studies muscle biopsies were taken from the vastus lateralis muscle. Changes in muscle fiber size with aging most likely depend on the location and the functional demands of a muscle. Age-related type II muscle fiber atrophy has been reported for the gastrocnemius (12), vastus lateralis $(23,29,49,50,52$, $54,56,59,77,107)$, biceps brachii (52), masseter (50), and pectoralis minor (93) muscle. However, generalization of these findings to other muscle groups in the human body should be performed with caution.

The process of sarcopenia is progressive in nature and occurs over a prolonged period of time during life. In addition, it is generally acknowledged that sarcopenia is a complex and multi-factorial process. Though the precise mechanisms underlying sarcopenia are still under debate, a number of possible explanations have been suggested. In principle, any loss of skeletal muscle mass originates from a structural imbalance between muscle protein synthesis and protein breakdown. As basal muscle protein synthesis and/or whole body breakdown rates do not appear to differ between healthy young and old people (110), it is now hypothesized that the loss of muscle mass with aging is, at least partly, attributed to a blunted protein synthetic response to the main anabolic stimuli, i.e. protein intake and physical activity $(21,35)$. However, the underlying mechanisms of the impaired protein synthetic response to food intake and/or physical activity remain to be elucidated. Other major factors considered to be involved in the agerelated loss of skeletal muscle mass include increased subclinical levels of inflammation (i.e. IL6, TNF- $\alpha$ and CRP) $(37,94,95,109)$, decreased anabolic hormone concentrations (i.e. IGF-1, testosterone, GH) $(32,101)$, neurological factors (i.e. motor unit loss, fiber type grouping) (105), mal-nutrition (i.e. insufficient dietary protein intake) $(65,66,103)$, and physical inactivity $(27,28,55)$. Beside these "external" factors, it has been suggested that certain intrinsic changes within the muscle may contribute to the decline in muscle mass with aging. More specifically a decline in the number and/or function of skeletal muscle stem cells, also known as satellite cells, has been suggested to occur with increasing age. These satellite cells are found to be essential in muscle fiber maintenance, growth and regeneration. As such, satellite cells may be an important contributing factor in the loss of skeletal muscle mass observed during normal aging. 


\section{SKELETAL MUSCLE SATELLITE CELLS}

Since their discovery by Mauro in 1961 (61), satellite cells have been identified as the main (or only) source of new myonuclei in postnatal skeletal muscle $(67,68)$. Muscle satellite cells owe their name to their localization under the basement membrane, but outside the plasma membrane of their associated muscle fiber. In adult skeletal muscle, satellite cells are normally in a quiescent state, residing in a niche, not exhibiting gene expression and/or protein synthesis. The satellite cell niche represents a dynamic unit changing between a quiescent and activated niche in response to external stimuli (e.g. exercise, injury, myotoxins and/or disease). To elucidate the behavior of satellite cells in skeletal muscle atrophy and/or hypertrophy we first need to consider the role of myonuclei in these processes.

\section{MYONUCLEI}

Muscle fibers contain hundreds of myonuclei and it is generally believed that each myonucleus controls the gene expression over a certain amount of cytoplasm, which is referred to as the myonuclear domain (11). It has been hypothesized that changes in muscle fiber size, i.e. muscle atrophy or hypertrophy, are achieved by the regulation of three important factors: 1 ) the number of nuclei in a single muscle fiber; 2 ) the rate of muscle protein synthesis per myonucleus; and 3) the rate of muscle protein breakdown (10). In accordance, the myonuclear domain theory stipulates that changes in muscle fiber size (e.g. hypertrophy or atrophy) are accompanied by a change in myonuclear content, myonuclear domain size or both (Figure 1). In line with this reasoning, muscle fiber atrophy has been associated with a decline in myonuclear number $(3,4,24-26$, $102)$ and/or a decline in myonuclear domain size $(5,10,111)$. Likewise, muscle fiber hypertrophy is associated with an increase in myonuclear number $(47,60,77)$ and myonuclear domain size $(46,77)$. Interestingly, more recent studies suggest that an increase in myonuclear number will only occur when muscle fiber size increases substantially (77). It has been hypothesized that the myonuclear domain size can increase to a certain extent (i.e. $\pm 2250 \mu^{2}$ ) by the upregulation of muscle protein synthesis (78). Thereafter, the incorporation of new myonuclei seems to be required to allow further muscle fiber hypertrophy. This "ceiling theory" implies that the myonuclear domain size has a threshold, beyond which additional myonuclei are prerequisite $(77,78)$. This is consistent with the idea that myonuclei support gene expression for a finite volume of cytoplasm. As myonuclei are post-mitotic, skeletal muscle satellite cells are required to provide additional myonuclei when needed. 

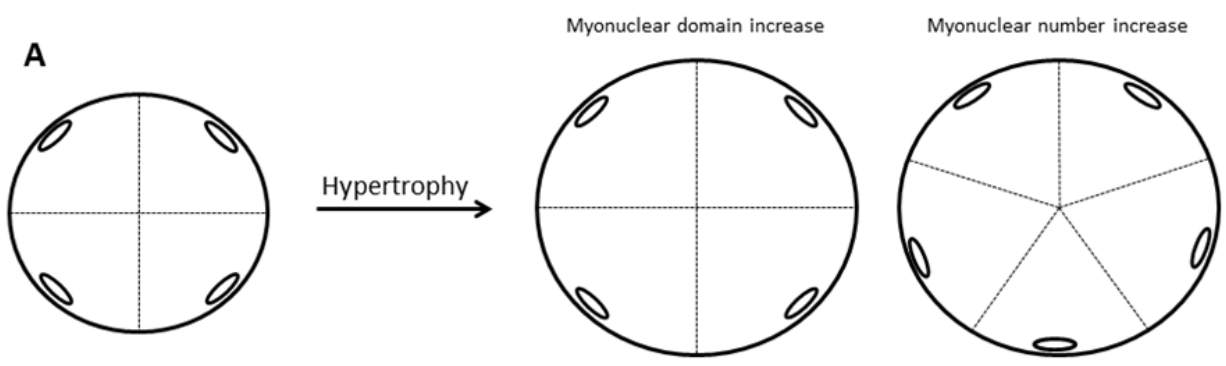

B

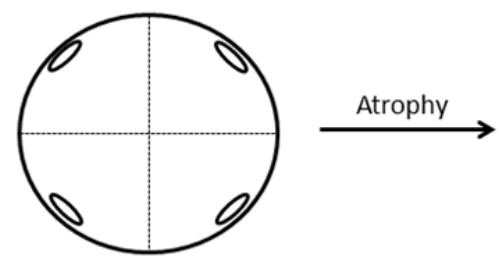

Myonuclear domain decrease

Myonuclear number decrease
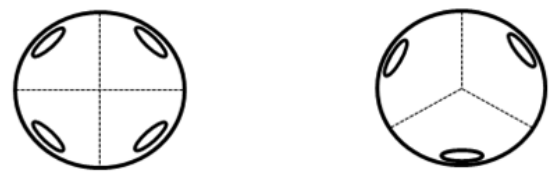

Figure 1 Schematic representation of the myonuclear domain theory during skeletal muscle fiber hypertrophy and atrophy. (A) Muscle fiber hypertrophy is associated with an increase in myonuclear domain size (due to increased protein synthesis induced by the existing myonuclei) and/or an increase in myonuclear number. (B) Muscle fiber atrophy is associated with a reduction in myonuclear domain size and/or number.

\section{SATELLITE CELL ACTIVATION, PROLIFERATION AND DIFFERENTIATION}

The first step in the process of supplying new myonuclei is the activation of satellite cells. Upon exposure to signals induced by a mechanical stimulus and/or damaged environment, satellite cells exit their quiescent state and start to proliferate. Proliferating satellite cells and their progeny are also known as myogenic precursor cells (MPC) or adult myoblasts. The activation of satellite cells is not only limited to the site of the muscle fiber damage. Previous studies have shown that localized damage on one end of the muscle fiber can lead to activation of all satellite cells along the entire myofiber and migration of active satellite cells to the regenerating site (98). Moreover, satellite cells have even been shown to migrate between muscle fibers, across barriers of basal lamina and/or connective tissue during muscle fiber regeneration and/or growth $(38,42$, 112). In adult muscle, the extent to which satellite cells respond to damage and/or exercise stimuli, relies on the expression of Pax7 and the myogenic regulatory factors (MRFs) comprising Myf5, MyoD, myogenin, and MRF4 (Figure 2). Sequential suppression and/or upregulation of Pax7 and MRFs are necessary for the progression of satellite cells through the different stages of the cell cycle. In contrast to quiescent satellite cells, active satellite cells are characterized by the rapid upregulation of myogenic transcription factor MyoD $(15-17,34,100)$ and Myf5 $(15,17)$. The increase in MyoD expression in satellite cells has been shown to occur as early as $12 \mathrm{~h}$ after injury and/or a single 
bout of exercise $(81,100)$. It has been hypothesized that satellite cells are able to enter different myogenic programs depending on whether Myf5 or MyoD expression predominates (90).

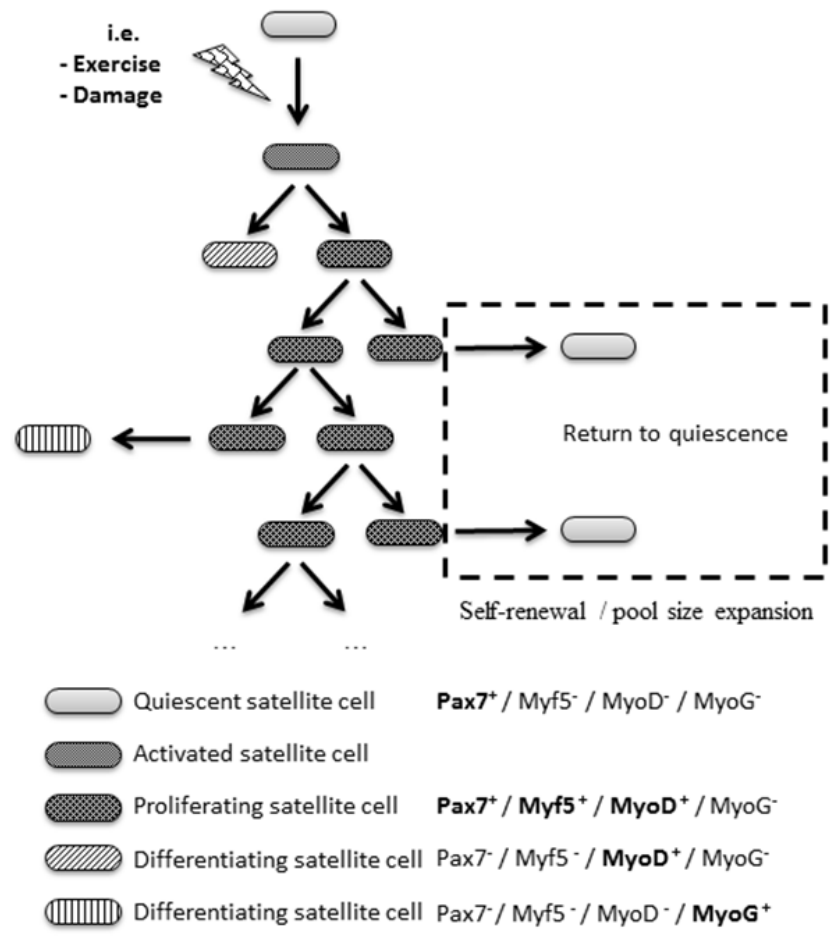

Figure 2 schematic representation of suggested routes for satellite cell activation, proliferation and differentiation/ self-renewal. The progression of satellite cells through the myogenic program is orchestrated by a group of transcription factors that dictate the progression from quiescence to activation, proliferation, differentiation and/or self-renewal. Originally quiescent satellite cells are characterized by the expression of Pax7 and not Myf5, MyoD or Myogenin. Upon stimulation (i.e. exercise, damage) satellite cells exit their quiescent state (satellite cell activation). Following activation, satellite cells can directly differentiate due to the upregulation of MyoD and down-regulation of Pax7. Alternatively, satellite cells start to proliferate, which can be characterized by the expression of Pax7 and the myogenic transcription factors Myf5 and MyoD. After proliferation, satellite cells begin differentiation by down-regulating Pax7 and up-regulating myogenin. Alternatively, activated satellite cells are also able to return to quiescence to maintain or expand the satellite cell pool size.

A predominant upregulation of MyoD has been suggested to be associated with a subpopulation of committed satellite cells, which are ready for immediate differentiation without preceding cell division (64). In contrast, predominance of Myf5 expression would direct satellite cells towards proliferation and delayed differentiation (91). Finally, satellite cells co-expressing both MyoD and Myf5 would exhibit intermediate prolif- 
eration and differentiation properties and is observed in most active satellite cells during normal myogenesis (Figure 2) (51).

After a limited number of proliferation rounds, the majority of satellite cells differentiate and fuse with damaged myofibers. Alternatively, newly formed myonuclei may fuse to each other to form new myofibers or allow extensive hypertrophy of existing muscle fibers. Terminal differentiation of the satellite cell is initiated by the expression of MRF4, myogenin $(16,17,34,100,113)$, and a decrease in Pax7 expression $(72,73)$. Importantly, when Pax7 expression remains high following the proliferation phase, satellite cells are able to escape the route of terminal differentiation and return back to a quiescent state, thereby promoting self-renewal (Figure 2) $(72,73)$. This mechanism of satellite cell self-renewal is important to maintain the satellite cell pool size (for future rounds of proliferation). A reduction in such capacity for self-renewal has been suggested to play a significant role in the age-related loss of muscle fiber size.

\section{SATELLITE CELLS IN AGING MUSCLE}

At birth, satellite cells account for $\sim 15 \%$ of all myonuclei (97), however, this proportion declines over time and by adulthood, only $1-4 \%$ of all myonuclei belong to satellite cells $(23,47,83)$. In adult muscle satellite cells are found to be crucial in muscle maintenance, growth and regeneration. However, at more advanced age a decline in the number of satellite cells and/or in their ability to become activated and proliferate upon stimuli may contribute to muscle fiber atrophy typically observed in elderly people. In the past, mixed results have been reported on whether satellite cell numbers decline with a more advancing age. Some reports have shown an age-related decline in satellite cell content in rat tibialis anterior muscle $(9,22)$ and in extensor digitorum longus muscle of mice (31), while others did not observe any decline in satellite cell number in rat levator (70) or mice soleus muscle with increasing age (96). Similar to the rodent studies, no conclusive evidence has been generated from human studies. Some report a reduction in skeletal muscle satellite cell content in the vastus lateralis (92, 107), biceps brachii (83), tibialis anterior (43), and masseter (83) muscle in the elderly, whereas others show no age-related differences $(23,36,77,88)$. As the age-related loss of muscle mass is generally associated with type II muscle fiber type specific atrophy, more recent studies have determined satellite cell numbers in type I and type II muscle fibers separately. Since the study by Verdijk et al. (107), several studies by different groups $(57,63,108)$ have now consistently shown that type II muscle fiber atrophy in the elderly is accompanied by a type II muscle fiber type specific reduction in satellite cell content. Whether a fiber type specific decline is satellite cell content is a cause or merely a consequence of muscle fiber atrophy remains to be established.

Apart from the age-related decline in satellite cell content, satellite cell dysfunction has been suggested to contribute to the loss of skeletal muscle fiber size with aging. An 
inability to properly activate, proliferate and/or differentiate satellite cells in response to anabolic stimuli might be an important contributing factor to a reduction in the regenerative potential of skeletal muscle tissue which can contribute to the age-related loss of muscle mass. In senescent muscle, it has previously been demonstrated that satellite cell activation is impaired in in vitro single fiber preparations $(7,99)$ and in vivo animal tissue (13). In addition, it has been suggested that the age-related reduction in regenerative potential is due to impaired Notch signaling, which has been suggested to be necessary for satellite cell proliferation and differentiation. Interestingly, Conboy et al. (14) have shown that satellite cell activation can be normalized by exposing aged muscle to a young systemic environment. These findings suggest that the intrinsic ability for satellite cells to activate and/or proliferate is retained even in very old muscle. Age-related changes in or interaction between the systemic environment and/or satellite cell niche are more likely to play a key role in the impaired satellite cell activation response with aging.

\section{SATelLite Cells AND EXeRCISE}

Exercise training, both resistance as well as endurance, has been show to improve muscle mass and strength, and increase performance capacity in both young and elderly people. However, the mechanism(s) by which exercise induces skeletal muscle hypertrophy remain poorly understood. Kadi et al. $(44,45)$ were the first to show an association between exercise induced muscle fiber hypertrophy and the increase in both myonuclei number and satellite cell content in human skeletal muscle, suggesting a key role for satellite cells in the skeletal muscle adaptive response to exercise.

The assumption that satellite cells are crucial during muscle fiber hypertrophy originates from the early $\gamma$-irradiation studies in which satellite cells from mice were ablated from the muscle. These studies demonstrated that following satellite cell ablation the muscle hypertrophic response to overload is blunted or even non-existent $(2,79,85$ 87). In human muscle, satellite cell content has been shown to increase significantly within 24 to $192 \mathrm{~h}$ after a single bout of exercise $(19,20,23,71)$. This would imply that satellite cell activation and proliferation occur within a short time period after an anabolic stimulus. The progression of satellite cells through the various stages of activation, proliferation and/or differentiation is mediated by the expression of Pax7 and different MRF's (i.e. MyoD, Myf-5, Myogenin and Mrf4). In response to a single bout of exercise MRF mRNA expression has been reported to increase substantially in healthy young subjects $(18,39,48,62,80,82,114)$. However, this exercise induced increase in MRF mRNA expression was shown to be attenuated in the elderly $(18,39,48,82)$. In addition, Dreyer et al. (23) showed that $24 \mathrm{~h}$ following a single bout of eccentric exercise, the increase in satellite cell content was greater in young $(+141 \%)$ when compared with elderly (+51\%) men. Together, these results may be indicative of impairments in satellite cell function in response to exercise in senescent muscle. Yet, a precise timeline for 
the changes in satellite cell content, activation status and associated signaling proteins remains to be elucidated in both healthy young and elderly men and women. In addition, as satellite cell content has been shown to differ between type I and II muscle fibers in the elderly, it could be hypothesized that satellite cell activation, proliferation and differentiation after an anabolic stimulus also occur in a fiber type specific manner, especially in older adults. However, it remains unknown whether a single bout of exercise induces a muscle fiber type specific change in satellite cell content and/or activation status.

Studies investigating the long-term adaptive response to exercise intervention have reported less consistent results in terms of muscle fiber hypertrophy, myonuclear and satellite cell content. In healthy young men, resistance type exercise training has been shown to increase muscle fiber size with a concomitant increase in both myonuclear and satellite cell content, suggesting successful incorporation of differentiated satellite cells $(44,46,74,77)$. In contrast, other studies show that resistance type exercise training induced muscle fiber hypertrophy is accompanied by an increase in satellite cell content without an increase in myonuclear content $(36,46,74)$. The discrepancy might be attributed to the fact that pre-existing myonuclei are able to increase their protein synthesis and support exercise induced increases in cytoplasmic volume, as proclaimed in the "ceiling theory". In accordance, it has been reported that muscle fiber hypertrophy in response to resistance type exercise training can be accompanied by an increase in myonuclear domain size, while myonuclear number remains equal throughout the training period.

Similar results have been reported when satellite cell content was studied in response to resistance type exercise training in healthy elderly individuals. Most studies show a substantial increase in both muscle fiber size and satellite cell content after 9-16 weeks of resistance type exercise training in older adults $(46,47,74,106,108)$. In contrast, muscle fiber hypertrophy has also been reported to occur without an increase in satellite cell content in response to 16 weeks of resistance type exercise training in health elderly men $(36,77)$. In addition, others have shown a significant increase in satellite cell content in the absence of muscle fiber hypertrophy after resistance type exercise training $(60,89)$. The apparent discrepancies might, in part, be explained by the lack of fiber type specific data on the changes in muscle fiber size and/or satellite cell content in response to prolonged resistance type exercise training. Whereas most studies assessed satellite cell content in mixed muscle tissue, more recent work has shown that in the vastus lateralis and deltoideus muscle, muscle fiber size and satellite cell content increase specifically in type II muscle fibers after long-term resistance type exercise training in healthy elderly men $(106,108)$. More research is warranted to elucidate these inconsistent findings on the proposed role of satellite cells and muscle fiber hypertrophy in response to prolonged resistance type exercise training in both young and elderly men and women.

In summary, both a decline in satellite cell number and/or changed function might be 
of key importance in understanding the molecular mechanisms responsible for the skeletal muscle mass loss during healthy aging. However, to provide more insight in the underlying mechanism it seems imperative to evaluate the acute and long-term changes in skeletal muscle satellite cell number and function associated with muscle fiber atrophy and exercise induced muscle fiber hypertrophy in both type I and type II muscle fibers separately. Furthermore, specific in vivo human studies are required to explore the potential difference in fiber type specific changes in satellite cell content and activation status between healthy young and elderly individuals during post-exercise recovery. Furthermore, nutrient intake is a decisive determinant of the muscle adaptive response during post-exercise recovery in terms of protein synthesis and breakdown, and net muscle protein accretion $(6,8,53,104)$. New studies are warranted to also elucidate the potential importance of dietary protein intake on satellite cell function and associated muscle fiber hypertrophy after an acute bout or prolonged resistance type exercise training. Together these results could reveal important mechanistic concepts of sarcopenia and may provide new leads in the development of effective intervention strategies to prevent and/or reverse the loss of skeletal muscle mass and function with aging. Therefore, in the present work we aimed to investigate the potential importance of satellite cells in age- (long-term) and disuse- (short-term) related muscle fiber atrophy, as well as the role of satellite cells in the muscle fiber type specific adaptive response to exercise training in both healthy young and elderly people and the influence of dietary protein intake herein.

\section{THESIS OUTLINE}

This thesis describes a series of studies in which we assessed the role of skeletal muscle satellite cells in the process of muscle fiber atrophy and/or hypertrophy in both healthy young and elderly men. In Chapter 2, we present age-related changes in muscle fiber size and satellite cell content over the entire human lifespan, and report a clear association between resistance type exercise training induced increases in satellite cell content and the extent of muscle fiber hypertrophy in elderly men. In Chapter 3, we assess in a longitudinal study whether short-term muscle fiber disuse atrophy is accompanied by a change in skeletal muscle satellite cell content and/or associated signaling pathways. In Chapter 4, we determined the impact of a single bout of exercise on satellite cell activation status during subsequent overnight recovery in healthy young men. In Chapter 5 , we show that satellite cell number and activation status respond in a fiber type specific manner 24 hours after a single bout of eccentric exercise. In chapter 6 , we extend on these findings by comparing the satellite cell adaptive response up to 72 hours after a single bout of resistance type exercise between healthy young and elderly men. In Chapter 7, we evaluate the role of dietary protein intake on the satellite cell adaptive response after a single bout of resistance type exercise in healthy young men. In Chapter 8 , we test the hypothesis that muscle fiber hypertrophy following 12 wks of re- 
sistance type exercise training can be augmented by protein supplementation prior to sleep. In Chapter 9 we assess whether a change in myonuclear domain size is required to elicit myonuclear accretion to support subsequent muscle hypertrophy during prolonged resistance type exercise training in healthy young men. In Chapter 10, we finally discuss the outcomes described in chapters 2-8 and provide a general conclusion. In addition, the implications of this thesis will be discussed and future research aims will be formulated targeting to extend current knowledge regarding the proposed role of satellite cells in skeletal muscle plasticity and the associated signaling pathways in both healthy and more compromised young and elderly people. 


\section{REFERENCES}

1. (CBS) CBvdS. Bevolkingsprognose 2012-2060: Langer leven, Langer werken. http://wwwcbsnl/NR/rdonlyres/DB34C87D-823D-49B4-AE3A3DE66CDCB1A/0/2012bevolkingprognoselangerlevenlanger werken. pdf 11-09-2013: 2012.

2. Adams G, Caiozzo V, Haddad F, and Baldwin K. Cellular and molecular responses to increased skeletal muscle loading after irradiation. American journal of physiology Cell physiology 283: 95, 2002.

3. Allen D, Linderman J, and Roy... R. Growth hormone/IGF-I and/or resistive exercise maintains myonuclear number in hindlimb unweighted muscles. Journal of Applied ... 1997.

4. Allen D, Roy R, and Edgerton V. Myonuclear domains in muscle adaptation and disease. Muscle Nerve 22: 1350-1360, 1999.

5. Aravamudan B, Mantilla C, Zhan W-Z, and Sieck G. Denervation effects on myonuclear domain size of rat diaphragm fibers. Journal of applied physiology 100: 1617-1622, 2006.

6. Biolo G, Tipton K, Klein S, and Wolfe R. An abundant supply of amino acids enhances the metabolic effect of exercise on muscle protein. Am J Physiol 273: 122-129, 1997.

7. Bockhold K, Rosenblatt J, and Partridge T. Aging normal and dystrophic mouse muscle: analysis of myogenicity in cultures of living single fibers. Muscle Nerve 21: 173-183, 1998.

8. Børsheim E, Tipton K, Wolf $S$, and Wolfe R. Essential amino acids and muscle protein recovery from resistance exercise. Am J Physiol 283: 648-657, 2002.

9. Brack A, Bildsoe $H$, and Hughes S. Evidence that satellite cell decrement contributes to preferential decline in nuclear number from large fibres during murine age-related muscle atrophy. Journal of cell science 118: 4813-4821, 2005.

10. Bruusgaard J, Egner I, Larsen T, Dupre-Aucouturier S, Desplanches D, and Gundersen K. No change in myonuclear number during muscle unloading and reloading. Journal of applied physiology 113: 290-296, 2012.

11. Cheek D. The control of cell mass and replication. The DNA unit--a personal 20-year study. Early human development 12: 211-239, 1985.

12. Coggan A, Spina R, and King... D. Histochemical and enzymatic comparison of the gastrocnemius muscle of young and elderly men and women. Journal of ... 1992.

13. Conboy I, Conboy M, Smythe G, and Rando T. Notch-mediated restoration of regenerative potential to aged muscle. Science (New York, NY) 302: 1575-1577, 2003.

14. Conboy I, and Rando T. Aging, stem cells and tissue regeneration: lessons from muscle. Cell cycle (Georgetown, Tex) 4: 407-410, 2005.

15. Cooper R, Tajbakhsh S, Mouly V, Cossu G, Buckingham M, and Butler-Browne G. In vivo satellite cell activation via Myf5 and MyoD in regenerating mouse skeletal muscle. Journal of cell science 112 ( $P t$ 17): 2895-2901, 1999.

16. Cornelison D, Olwin B, Rudnicki M, and Wold B. MyoD(-/-) satellite cells in single-fiber culture are differentiation defective and MRF4 deficient. Developmental biology 224: 122-137, 2000.

17. Cornelison D, and Wold B. Single-cell analysis of regulatory gene expression in quiescent and activated mouse skeletal muscle satellite cells. Developmental biology 191: 270-283, 1997.

18. Costa A, Dalloul H, Hegyesi H, Apor P, Csende Z, Racz L, Vaczi M, et al. Impact of repeated bouts of eccentric exercise on myogenic gene expression. European journal of applied physiology 101: 427-436, 2007.

19. Crameri R, Aagaard P, Qvortrup K, Langberg H, Olesen J, and Kjaer M. Myofibre damage in human skeletal muscle: effects of electrical stimulation versus voluntary contraction. The Journal of physiology 583: 365-380, 2007.

20. Crameri R, Langberg H, Magnusson P, Jensen C, Schrøder H, Olesen J, Suetta C, et al. Changes in satellite cells in human skeletal muscle after a single bout of high intensity exercise. The Journal of physiology 558: 333-340, 2004. 
21. Cuthbertson D, Smith K, Babraj J, Leese G, Waddell T, Atherton P, Wackerhage H, et al. Anabolic signaling deficits underlie amino acid resistance of wasting, aging muscle. FASEB journal : official publication of the Federation of American Societies for Experimental Biology 19: 422-424, 2005.

22. Dedkov E, Borisov A, and Wernig... A. Aging of skeletal muscle does not affect the response of satellite cells to denervation. ... of Histochemistry \& ... 2003.

23. Dreyer H, Blanco C, Sattler F, Schroeder E, and Wiswell R. Satellite cell numbers in young and older men 24 hours after eccentric exercise. Muscle Nerve 33: 242-253, 2006.

24. Dupont-Versteegden E, Murphy R, Houlé J, Gurley C, and Peterson C. Activated satellite cells fail to restore myonuclear number in spinal cord transected and exercised rats. The American journal of physiology 277: 97, 1999.

25. Dupont-Versteegden E, Murphy R, Houlé J, Gurley C, and Peterson C. Mechanisms leading to restoration of muscle size with exercise and transplantation after spinal cord injury. American journal of physiology Cell physiology 279: 84, 2000.

26. Dupont-Versteegden E, Strotman B, Gurley C, Gaddy D, Knox M, Fluckey J, and Peterson C. Nuclear translocation of EndoG at the initiation of disuse muscle atrophy and apoptosis is specific to myonuclei. American journal of physiology Regulatory, integrative and comparative physiology 291: 40, 2006.

27. Evans W. Skeletal muscle loss: cachexia, sarcopenia, and inactivity. Am J Clin Nutr 91: 2010.

28. Freiberger E, Sieber C, and Pfeifer K. Physical activity, exercise, and sarcopenia - future challenges. Wiener medizinische Wochenschrift (1946) 161: 416-425, 2011.

29. Frontera W, Reid K, Phillips E, Krivickas L, Hughes V, Roubenoff R, and Fielding R. Muscle fiber size and function in elderly humans: a longitudinal study. Journal of applied physiology 105: 637-642, 2008.

30. Gallagher D, Ruts E, Visser M, Heshka S, Baumgartner R, Wang J, Pierson R, et al. Weight stability masks sarcopenia in elderly men and women. American journal of physiology Endocrinology and metabolism 279: 75, 2000.

31. Gibson M, and Schultz E. Age-related differences in absolute numbers of skeletal muscle satellite cells. Muscle Nerve 6: 574-580, 1983.

32. Giovannini S, Marzetti E, Borst S, and Leeuwenburgh C. Modulation of GH/IGF-1 axis: potential strategies to counteract sarcopenia in older adults. Mech Ageing Dev 129: 593-601, 2008.

33. Goodpaster B, Carlson C, Visser M, Kelley D, Scherzinger A, Harris T, Stamm E, et al. Attenuation of skeletal muscle and strength in the elderly: The Health $A B C$ Study. Journal of applied physiology 90 : 2157-2165, 2001.

34. Grounds M, Garrett K, Lai M, Wright W, and Beilharz M. Identification of skeletal muscle precursor cells in vivo by use of MyoD1 and myogenin probes. Cell and tissue research 267: 99-104, 1992.

35. Guillet C, Prod'homme M, Balage M, Gachon P, Giraudet C, Morin L, Grizard J, et al. Impaired anabolic response of muscle protein synthesis is associated with S6K1 dysregulation in elderly humans. FASEB journal : official publication of the Federation of American Societies for Experimental Biology 18: 15861587, 2004.

36. Hikida R, Walsh S, Barylski N, Campo G, Hagerman F.Staron R. Is hypertrophy limited in elderly muscle fibers? A comparison of elderly and young strength-trained men. Basic Appl Myol 8: 419-427, 1998.

37. Hubbard R, O'Mahony M, Savva G, Calver B, and Woodhouse K. Inflammation and frailty measures in older people. Journal of cellular and molecular medicine 13: 3103-3109, 2009.

38. Hughes $\mathrm{S}$, and Blau $\mathrm{H}$. Migration of myoblasts across basal lamina during skeletal muscle development. Nature 345: 350-353, 1990.

39. Hulmi J, Kovanen V, Selänne H, Kraemer W, Häkkinen K, and Mero A. Acute and long-term effects of resistance exercise with or without protein ingestion on muscle hypertrophy and gene expression. Amino acids 37: 297-308, 2009.

40. I.H. R. Summary Comments. Am J Clin Nutr 50: 1231-1233, 1989.

41. Janssen I, Heymsfield S, Wang Z, and Ross R. Skeletal muscle mass and distribution in 468 men and women aged 18-88 yr. Journal of applied physiology 89: 81-88, 2000.

42. Jockusch $\mathrm{H}$, and Voigt $\mathrm{S}$. Migration of adult myogenic precursor cells as revealed by GFP/nLacZ labelling of mouse transplantation chimeras. Journal of cell science 116: 1611-1616, 2003. 
43. Kadi F, Charifi N, Denis C, and Lexell J. Satellite cells and myonuclei in young and elderly women and men. Muscle Nerve 29: 120-127, 2004.

44. Kadi F, Eriksson A, Holmner S, Butler-Browne G, and Thornell L. Cellular adaptation of the trapezius muscle in strength-trained athletes. Histochemistry and cell biology 111: 189-195, 1999.

45. Kadi F, Eriksson A, Holmner S, and Thornell L. Effects of anabolic steroids on the muscle cells of strengthtrained athletes. Med Sci Sports Exerc 31: 1528-1534, 1999.

46. Kadi F, Schjerling P, Andersen L, Charifi N, Madsen J, Christensen L, and Andersen J. The effects of heavy resistance training and detraining on satellite cells in human skeletal muscles. The Journal of physiology 558: 1005-1012, 2004.

47. Kadi F, and Thornell L. Concomitant increases in myonuclear and satellite cell content in female trapezius muscle following strength training. Histochemistry and cell biology 113: 99-103, 2000.

48. Kim J-s, Cross J, and Bamman M. Impact of resistance loading on myostatin expression and cell cycle regulation in young and older men and women. American journal of physiology Endocrinology and metabolism 288: 9, 2005.

49. Kim J-s, Kosek D, Petrella J, Cross J, and Bamman M. Resting and load-induced levels of myogenic gene transcripts differ between older adults with demonstrable sarcopenia and young men and women. Journal of applied physiology 99: 2149-2158, 2005.

50. Kirkeby S, and Garbarsch C. Aging affects different human muscles in various ways. An image analysis of the histomorphometric characteristics of fiber types in human masseter and vastus lateralis muscles from young adults and the very old. Histology and histopathology 15: 61-71, 2000.

51. Kitzmann M, Carnac G, Vandromme M, Primig M, Lamb N, and Fernandez A. The muscle regulatory factors MyoD and myf-5 undergo distinct cell cycle-specific expression in muscle cells. The Journal of cell biology 142: 1447-1459, 1998.

52. Klitgaard H, Mantoni M, Schiaffino S, Ausoni S, Gorza L, Laurent-Winter C, Schnohr P, et al. Function, morphology and protein expression of ageing skeletal muscle: a cross-sectional study of elderly men with different training backgrounds. Acta physiologica Scandinavica 140: 41-54, 1990.

53. Koopman R, Walrand S, Beelen M, Gijsen A, Kies A, Boirie Y, Saris W, et al. Dietary protein digestion and absorption rates and the subsequent postprandial muscle protein synthetic response do not differ between young and elderly men. The Journal of nutrition 139: 1707-1713, 2009.

54. Kosek D, Kim J-S, Petrella J, Cross J, and Bamman M. Efficacy of 3 days/wk resistance training on myofiber hypertrophy and myogenic mechanisms in young vs. older adults. Journal of applied physiology 101: 531-544, 2006.

55. Landi F, Abbatecola A, Provinciali M, Corsonello A, Bustacchini S, Manigrasso L, Cherubini A, et al. Moving against frailty: does physical activity matter? Biogerontology 11: 537-545, 2010.

56. Larsson L, Sjödin B, and Karlsson J. Histochemical and biochemical changes in human skeletal muscle with age in sedentary males, age 22--65 years. Acta physiologica Scandinavica 103: 31-39, 1978.

57. Leenders M, Verdijk L, van der Hoeven L, van Kranenburg J, Nilwik R, and van Loon L. Elderly men and women benefit equally from prolonged resistance-type exercise training. J Gerontol A Biol Sci Med Sci 68: 769-779, 2013.

58. Lexell J, and Downham D. What is the effect of ageing on type 2 muscle fibres? Journal of the neurological sciences 107: 250-251, 1992.

59. Lexell J, Taylor C, and Sjöström M. What is the cause of the ageing atrophy? Total number, size and proportion of different fiber types studied in whole vastus lateralis muscle from 15- to 83-year-old men. Journal of the neurological sciences 84: 275-294, 1988.

60. Mackey A, Esmarck B, Kadi F, Koskinen S, Kongsgaard M, Sylvestersen A, Hansen J, et al. Enhanced satellite cell proliferation with resistance training in elderly men and women. Scandinavian journal of medicine \& science in sports 17: 34-42, 2007.

61. Mauro A. Satellite cell of skeletal muscle fibers. The Journal of biophysical and biochemical cytology 9 : 493-495, 1961. 
62. McKay B, O'Reilly C, Phillips S, Tarnopolsky M, and Parise G. Co-expression of IGF-1 family members with myogenic regulatory factors following acute damaging muscle-lengthening contractions in humans. The Journal of physiology 586: 5549-5560, 2008.

63. McKay B, Ogborn D, Bellamy L, Tarnopolsky M, and Parise G. Myostatin is associated with age-related human muscle stem cell dysfunction. FASEB journal : official publication of the Federation of American Societies for Experimental Biology 26: 2509-2521, 2012.

64. Montarras D, Lindon C, Pinset C, and Domeyne P. Cultured myf5 null and myoD null muscle precursor cells display distinct growth defects. Biology of the cell / under the auspices of the European Cell Biology Organization 92: 565-572, 2000.

65. Morley J. Anorexia of aging: physiologic and pathologic. Am J Clin Nutr 66: 760-773, 1997.

66. Morley JE. Pathophysiology of the anorexia of aging. Current opinion in clinical nutrition and metabolic care 16: 27-32, 2013.

67. Moss F, and Leblond C. Nature of dividing nuclei in skeletal muscle of growing rats. The Journal of cell biology 44: 459-462, 1970.

68. Moss F, and Leblond C. Satellite cells as the source of nuclei in muscles of growing rats. The Anatomical record 170: 421-435, 1971.

69. Nilwik R, Snijders T, Leenders M, Groen BB, van Kranenburg J, Verdijk LB, and van Loon LJ. The decline in skeletal muscle mass with aging is mainly attributed to a reduction in type II muscle fiber size. Exp Gerontol 48: 492-498, 2013.

70. Nnodim J. Satellite cell numbers in senile rat levator ani muscle. Mech Ageing Dev 112: 99-111, 2000.

71. O'Reilly C, McKay B, Phillips S, Tarnopolsky M, and Parise G. Hepatocyte growth factor (HGF) and the satellite cell response following muscle lengthening contractions in humans. Muscle Nerve 38: 14341442, 2008.

72. Olguin $H$, and Olwin B. Pax-7 up-regulation inhibits myogenesis and cell cycle progression in satellite cells: a potential mechanism for self-renewal. Developmental biology 275: 375-388, 2004.

73. Olguin H, Yang Z, Tapscott S, and Olwin B. Reciprocal inhibition between Pax7 and muscle regulatory factors modulates myogenic cell fate determination. The Journal of cell biology 177: 769-779, 2007.

74. Olsen S, Aagaard P, Kadi F, Tufekovic G, Verney J, Olesen J, Suetta C, et al. Creatine supplementation augments the increase in satellite cell and myonuclei number in human skeletal muscle induced by strength training. The Journal of physiology 573: 525-534, 2006.

75. Organization WH. What are the public health implications of global ageing? http://wwwwhoint/features/qa/42/en/indexhtml 11-09-2013: 2012.

76. Overend T, Cunningham D, Paterson D, and Lefcoe M. Thigh composition in young and elderly men determined by computed tomography. Clinical physiology (Oxford, England) 12: 629-640, 1992.

77. Petrella J, Kim J-s, Cross J, Kosek D, and Bamman M. Efficacy of myonuclear addition may explain differential myofiber growth among resistance-trained young and older men and women. American journal of physiology Endocrinology and metabolism 291: 46, 2006.

78. Petrella J, Kim J-S, Mayhew D, Cross J, and Bamman M. Potent myofiber hypertrophy during resistance training in humans is associated with satellite cell-mediated myonuclear addition: a cluster analysis. Journal of applied physiology 104: 1736-1742, 2008.

79. Phelan J, and Gonyea W. Effect of radiation on satellite cell activity and protein expression in overloaded mammalian skeletal muscle. The Anatomical record 247: 179-188, 1997.

80. Psilander N, Damsgaard R, and Pilegaard H. Resistance exercise alters MRF and IGF-I mRNA content in human skeletal muscle. Journal of applied physiology 95: 1038-1044, 2003.

81. Rantanen J, Hurme T, Lukka R, Heino J, and Kalimo H. Satellite cell proliferation and the expression of myogenin and desmin in regenerating skeletal muscle: evidence for two different populations of satellite cells. Laboratory investigation; a journal of technical methods and pathology 72: 341-347, 1995.

82. Raue U, Slivka D, Jemiolo B, Hollon C, and Trappe S. Myogenic gene expression at rest and after a bout of resistance exercise in young (18-30 yr) and old (80-89 yr) women. Journal of applied physiology 101: 53-59, 2006. 
83. Renault V, Thornell L-E, Eriksson P-O, Butler-Browne G, Mouly V, and Thorne L-E. Regenerative potential of human skeletal muscle during aging. Aging cell 1: 132-139, 2002.

84. Rice C, Cunningham D, Paterson D, and Lefcoe M. Arm and leg composition determined by computed tomography in young and elderly men. Clinical physiology (Oxford, England) 9: 207-220, 1989.

85. Rosenblatt J, and Parry D. Adaptation of rat extensor digitorum longus muscle to gamma irradiation and overload. Pflügers Archiv : European journal of physiology 423: 255-264, 1993.

86. Rosenblatt J, and Parry D. Gamma irradiation prevents compensatory hypertrophy of overloaded mouse extensor digitorum longus muscle. Journal of applied physiology 73: 2538-2543, 1992.

87. Rosenblatt J, Yong D, and Parry D. Satellite cell activity is required for hypertrophy of overloaded adult rat muscle. Muscle Nerve 17: 608-613, 1994.

88. Roth S, Martel G, Ivey F, Lemmer J, Metter E, Hurley B, and Rogers M. Skeletal muscle satellite cell populations in healthy young and older men and women. The Anatomical record 260: 351-358, 2000.

89. Roth S, Martel G, Ivey F, Lemmer J, Tracy B, Metter E, Hurley B, et al. Skeletal muscle satellite cell characteristics in young and older men and women after heavy resistance strength training. J Gerontol $A$ Biol Sci Med Sci 56: 7, 2001.

90. Rudnicki M, Le Grand F, McKinnell I, and Kuang S. The molecular regulation of muscle stem cell function. Cold Spring Harbor symposia on quantitative biology 73: 323-331, 2008.

91. Sabourin L, Girgis-Gabardo A, Seale P, Asakura A, and Rudnicki M. Reduced differentiation potential of primary MyoD-/- myogenic cells derived from adult skeletal muscle. The Journal of cell biology 144: 631$643,1999$.

92. Sajko S, Kubínová L, Cvetko E, Kreft M, Wernig A, and Erzen I. Frequency of M-cadherin-stained satellite cells declines in human muscles during aging. The journal of histochemistry and cytochemistry : official journal of the Histochemistry Society 52: 179-185, 2004.

93. Sato $\mathrm{T}$, Akatsuka H, Kito K, Tokoro $\mathrm{Y}$, and Tauchi... H. Age changes in size and number of muscle fibers in human minor pectoral muscle. Mechanisms of ageing ... 1984.

94. Schaap L, Pluijm S, Deeg D, Harris T, Kritchevsky S, Newman A, Colbert L, et al. Higher inflammatory marker levels in older persons: associations with 5-year change in muscle mass and muscle strength. J Gerontol A Biol Sci Med Sci 64: 1183-1189, 2009.

95. Schaap L, Pluijm S, Deeg D, and Visser M. Inflammatory markers and loss of muscle mass (sarcopenia) and strength. The American journal of medicine 119: 2013989888-2013989817, 2006.

96. Schäfer R, Zweyer M, Knauf $U$, Mundegar R, and Wernig A. The ontogeny of soleus muscles in $m d x$ and wild type mice. Neuromuscular disorders 15: 57-64, 2005.

97. Schmalbruch $\mathrm{H}$, and Hellhammer $\mathrm{U}$. The number of satellite cells in normal human muscle. The Anatomical record 185: 279-287, 1976.

98. Schultz $E$, Jaryszak $D$, and Valliere $C$. Response of satellite cells to focal skeletal muscle injury. Muscle Nerve 8: 217-222, 1985.

99. Schultz E, and Lipton B. Skeletal muscle satellite cells: changes in proliferation potential as a function of age. Mech Ageing Dev 20: 377-383, 1982.

100. Smith C, Janney M, and Allen R. Temporal expression of myogenic regulatory genes during activation, proliferation, and differentiation of rat skeletal muscle satellite cells. Journal of cellular physiology 159 : 379-385, 1994.

101. Szulc P, Duboeuf F, Marchand F, and Delmas P. Hormonal and lifestyle determinants of appendicular skeletal muscle mass in men: the MINOS study. Am J Clin Nutr 80: 496-503, 2004.

102. Tang $\mathrm{H}$, Cheung $\mathrm{W}, \mathrm{Ip} \mathrm{F}$, and Ip N. Identification and characterization of differentially expressed genes in denervated muscle. Molecular and cellular neurosciences 16: 127-140, 2000.

103. Tieland M, Borgonjen-Van den Berg K, van Loon L, and de Groot L. Dietary protein intake in communitydwelling, frail, and institutionalized elderly people: scope for improvement. European journal of nutrition 51: 173-179, 2012.

104. Tipton K, Ferrando A, and Phillip S. Postexercise net protein synthesis in human muscle from orally administered amino acids. Amerc J Physiol 276:E628-634,1999.

105. Vandervoort A. Aging of the human neuromuscular system. Muscle Nerve 25: 17-25, 2002. 
106. Verdijk L, Gleeson B, Jonkers R, Meijer K, Savelberg H, Dendale P, and van Loon L. Skeletal muscle hypertrophy following resistance training is accompanied by a fiber type-specific increase in satellite cell content in elderly men. J Gerontol A Biol Sci Med Sci 64: 332-339, 2009.

107. Verdijk L, Koopman R, Schaart G, Meijer K, Savelberg H, and van Loon L. Satellite cell content is specifically reduced in type II skeletal muscle fibers in the elderly. American journal of physiology Endocrinology and metabolism 292: 7, 2007.

108. Verney J, Kadi F, Charifi N, Féasson L, Saafi M, Castells J, Piehl-Aulin K, et al. Effects of combined lower body endurance and upper body resistance training on the satellite cell pool in elderly subjects. Muscle Nerve 38: 1147-1154, 2008.

109. Visser M, Pahor M, Taaffe D, Goodpaster B, Simonsick E, Newman A, Nevitt M, et al. Relationship of interleukin- 6 and tumor necrosis factor-alpha with muscle mass and muscle strength in elderly men and women: the Health ABC Study. J Gerontol A Biol Sci Med Sci 57: 32, 2002.

110. Volpi E, Sheffield-Moore M, Rasmussen B, and Wolfe R. Basal muscle amino acid kinetics and protein synthesis in healthy young and older men. JAMA : the journal of the American Medical Association 286: 1206-1212, 2001.

111. Wada KI, Takahashi H, Katsuta S, and Soya $\mathrm{H}$. No decrease in myonuclear number after long-term denervation in mature mice. American journal of physiology Cell physiology 283: 8, 2002.

112. Watt D, Morgan J, Clifford M, and Partridge T. The movement of muscle precursor cells between adjacent regenerating muscles in the mouse. Anatomy and embryology 175: 527-536, 1987.

113. Yablonka-Reuveni Z, and Rivera A. Temporal expression of regulatory and structural muscle proteins during myogenesis of satellite cells on isolated adult rat fibers. Developmental biology 164: 588-603, 1994.

114. Yang Y, Creer A, Jemiolo B, and Trappe S. Time course of myogenic and metabolic gene expression in response to acute exercise in human skeletal muscle. Journal of applied physiology 98: 1745-1752, 2005. 


\title{
CHAPTER 2
}

\section{Satellite cells in human skeletal muscle: from birth to old age}

\author{
Lex B. Verdijk \\ Tim Snijders \\ Maarten Drost \\ Tammo Delhaas \\ Fawzi Kadi \\ Luc J.C. van Loon
}




\section{ABStract}

Introduction: Changes in satellite cell content play a key role in regulating skeletal muscle growth and atrophy. Yet, there is little information on changes in satellite cell content from birth to old age in humans. The present study defines muscle fiber typespecific satellite cell content in human skeletal muscle tissue over the entire lifespan.

Methods: Muscle biopsies were collected in 165 subjects, from different muscles of children undergoing surgery $(<18 \mathrm{y} ; \mathrm{n}=13)$, and from the vastus lateralis muscle of young adult (18-49y; $n=50)$, older $(50-69 y ; n=53)$, and senescent subjects (70-86y; $n=49)$. In a subgroup of 51 aged subjects $(71 \pm 6 y)$, additional biopsies were collected after 12 weeks of supervised resistance type exercise training. Immunohistochemistry was applied to assess skeletal muscle fiber type-specific composition, size, and satellite cell content

Results: From birth to adulthood, muscle fiber size increased tremendously with no major changes in muscle fiber satellite cell content, and no differences between type I and II muscle fibers. In contrast to type I muscle fibers, type II muscle fiber size was substantially smaller with increasing age in adults $(r=-0.56 ; P<0.001)$. This was accompanied by an age-related reduction in type II muscle fiber satellite cell content $(r=-0.57$; $P<0.001)$. Twelve weeks of resistance type exercise training significantly increased type II muscle fiber size and satellite cell content.

Conclusion: We conclude that type II muscle fiber atrophy with aging is accompanied by a specific decline in type II muscle fiber satellite cell content. Resistance type exercise training represents an effective strategy to increase satellite cell content and reverse type II muscle fiber atrophy. 


\section{INTRODUCTION}

It has been over 50 years since the discovery of satellite cells as the stem cells of skeletal muscle tissue (27). In adult skeletal muscle, satellite cells normally reside in a quiescent state in their niche below the basement membrane. Upon appropriate stimuli, satellite cells become activated and will start to proliferate $(10,15)$. Subsequently, they can either differentiate to form new myonuclei, or return to quiescence. The latter will replenish the resident satellite cell pool through self-renewal $(10,15,18,49)$.

Normal myogenesis, as in childhood growth, is established by extensive hypertrophy of the muscle fibers, which is accompanied by a concomitant increase in nuclear number $(31,43)$. As such, childhood development requires the continuous activation, proliferation and differentiation of satellite cells into new myonuclei, likely resulting in a relative decline of the satellite cell pool size. In adulthood, satellite cells are essential for maintenance, repair, and hypertrophy of skeletal muscle tissue. After the third decade of life skeletal muscle mass and strength start to decline, with a more progressive decline after the fifth decade $(16,22)$. The loss of skeletal muscle mass results in functional impairments and an increased risk of developing chronic metabolic disease at an advanced age (12). At the myocellular level, the age-related loss of muscle tissue is characterized by specific type II muscle fiber atrophy $(20,21)$. Since satellite cells represent the stem cells responsible for muscle fiber maintenance, a decline in satellite cell content and/or function would likely contribute to the loss of muscle mass with aging. Whereas some studies have reported an age-related decline in satellite cell content (17, $35)$, others failed to confirm these findings $(11,36)$. Previous work from our laboratory suggests that this inconsistency may be explained by the lack of muscle fiber typespecific data (46). However, it remains to be determined how satellite cell content changes over the lifespan. We hypothesize that throughout childhood, both type I and II muscle fiber size will increase without major changes in the absolute number of satellite cells. Furthermore, we hypothesize that throughout adulthood type II muscle fiber satellite cell content declines with an increasing age, with the greater differences observed in senescence.

Resistance type exercise training represents an effective interventional strategy to increase muscle mass and function in the elderly $(13,14)$. Prolonged resistance type exercise training has been shown to result in both type I and/or type II muscle fiber hypertrophy in elderly subjects $(26,40)$. Since satellite cells are the only known source to provide additional myonuclei to muscle fibers, an increase in satellite cell content is required to allow substantial muscle fiber hypertrophy. Though an increase in satellite cell content in response to prolonged resistance training has been reported by some $(24,37)$, others have failed to confirm those findings (33). This discrepancy is, at least partly, explained by the lack of muscle fiber-type specific data $(41,44,47)$. We hypothesize that prolonged resistance type exercise training in the elderly increases satellite cell content in the type II muscle fibers, thereby allowing type II muscle fiber hypertro- 
phy. Therefore, we examined whether the resistance type exercise training-induced increase in type II muscle fiber size can be predicted by the concomitant increase in satellite cell content.

The primary objective of the present study was to define muscle fiber type-specific satellite cell content in skeletal muscle tissue derived from human subjects over the entire lifespan. Our second objective was to determine whether age-related changes in muscle fiber satellite cell content can be reversed following prolonged resistance type exercise training. Therefore, muscle biopsies were collected in a large group of subjects ( $n=165$, age: 0-86 y) after which samples were analyzed for muscle fiber type-specific size, composition, and myonuclear and satellite cell content. Furthermore, 51 of the older individuals were subjected to 12 weeks of resistance type exercise training to assess the impact on muscle fiber size and satellite cell content.

\section{MethodS}

\section{Subjects}

A total of 13 children under the age of $18 \mathrm{y}$ and 152 healthy male adult subjects (age: $18-86$ y) were included in the present study. Skeletal muscle biopsy samples from all subjects under the age of 18 y were collected during cardiothoracic surgery not related to any pathology directly affecting skeletal muscle tissue morphology and/or function (i.e. none of the children underwent surgery for cardiac failure) (9). Adult subjects from various studies that were performed within our laboratory over the past 5 years were selected based on the availability of a skeletal muscle biopsy sample, taken in the morning following an overnight fast, with no intense physical activity or exercise for at least 3 days prior to biopsy collection. All subjects were healthy, independently living volunteers without any major comorbidities and had not participated in any structured exercise training program for at least 3 years. Biopsies from subjects with orthopedic and/or cardiovascular abnormalities or type 2 diabetes were excluded from analyses. Adult subjects were equally divided over 3 groups based on age: young adult (18-49 y; $n=50$ ), older (50-69y; $n=53$ ), and senescent ( $\geq 70 y ; n=49$ ). All subjects had been informed on the nature and possible risks of the experimental procedures, before written informed consent was obtained from the subjects, or their legal representatives in the case of children. All procedures were performed in compliance with the Declaration of Helsinki and approved by the Medical Ethics Committees of the Maastricht University Medical Centre+ and the University of Leuven.

\section{Muscle biopsies}

Muscle biopsies from all subjects under the age of 18 y $(n=13)$ were taken during nonmuscle related cardiothoracic surgery, from various muscle groups, i.e. rectus abdominis, pectoralis major, or sartorius. Muscle biopsies from healthy adults were taken in 
the morning, after an overnight fast and following 30 min of supine rest; using the percutaneous needle biopsy technique, biopsies were taken from the vastus lateralis muscle, $15 \mathrm{~cm}$ above the patella, after local anesthesia (3). Any visible non-muscle tissue was removed from the biopsy samples, which were then embedded in Tissue-Tek (Sakura Finetek, Zoeterwoude, The Netherlands), immediately frozen in liquid nitrogencooled isopentane, and stored at $-80^{\circ} \mathrm{C}$ until further analyses.

\section{Resistance type exercise training}

To determine the impact of prolonged resistance type exercise training on satellite cell content in older individuals, a subset of 51 aged subjects (71 56 y) participated in a 12 wk progressive resistance type exercise training program. Details of the exercise program have been reported previously (45). In short, supervised resistance-type exercise training was performed $3 \mathrm{x} / \mathrm{wk}$ for a 12 -wk period. Training consisted of a 5-min warmup on a cycle ergometer, followed by 4 sets on both the leg press and leg-extension machines, followed by a 5 -min cooling down period on the cycle ergometer. The postintervention muscle biopsy sample was taken from the same leg 4 days after performing the last exercise session.

\section{Immunohistochemistry}

From all muscle biopsies, $5-\mu \mathrm{m}$ thick cryosections were cut at $-20^{\circ} \mathrm{C}$, and samples were mounted on pre-cleaned uncoated glass slides. Care was taken to properly align the samples for cross-sectional fiber analyses. Serial cross-sections were stained for muscle fiber typing and myocellular satellite cell content as described previously (44). In short, staining procedures were as follows. After fixation ( $5 \mathrm{~min}$ acetone), slides were airdried and incubated for $60 \mathrm{~min}$ at room temperature with primary antibodies directed against laminin and either myosin heavy chain (MHC)-I or CD56, to stain type I muscle fibers and satellite cells, respectively. CD56 was chosen as it has been validly used to identify satellite cells in the majority of human studies (e.g. (11, 17, 24, 33, 34, 44, 47). After incubation with primary antibodies, slides were washed ( $3 * 5 \mathrm{~min}$ PBS). Appropriate secondary antibodies were applied, diluted together with DAPI to stain myonuclei. After a final washing step, all slides were mounted with cover glasses. Antibodies for immunohistochemical analyses were purchased from DSHB (lowa City, IA: A4.951 for MHC-I), Sigma (Zwijndrecht, the Netherlands: laminin), BD Biosciences (San Jose, CA: CD56), and Molecular Probes (Invitrogen, Breda, the Netherlands: DAPI, and secondary antibodies). To control for any potential effects of the underlying pathology (e.g. cyanotic heart disease) on skeletal muscle characteristics in children, a staining for carbonic anhydrase IX was performed to detect hypoxia-affected muscle fibers (9). Muscle biopsies that showed signs of hypoxia were excluded from the analyses. 

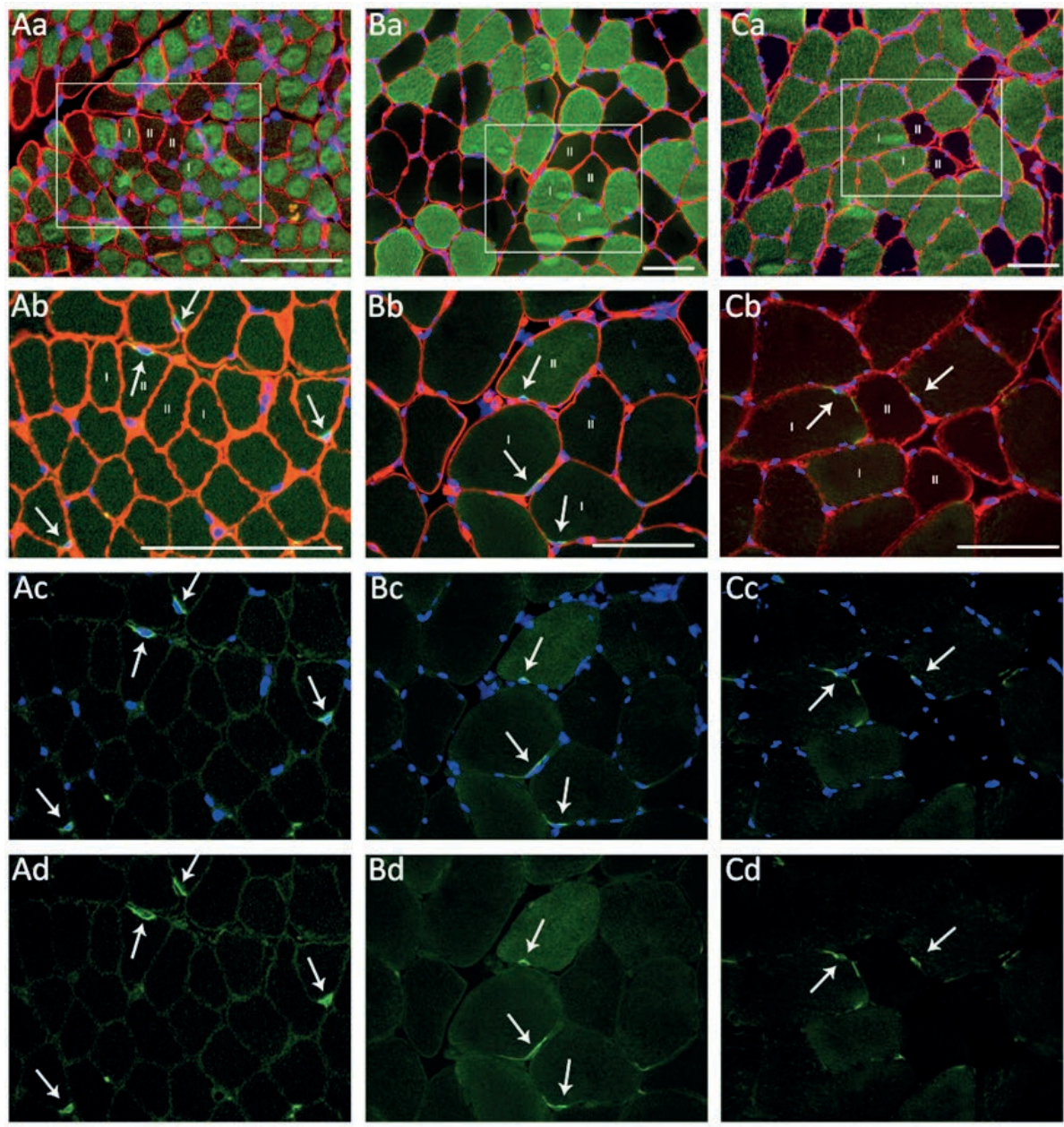

Figure 1 Muscle fiber type-specific analyses for muscle fiber size and satellite cell content in muscle tissue obtained from a child ( 8 $\mathrm{mth}$, or $0.7 \mathrm{y} ; \mathrm{A})$, a young adult $(20 \mathrm{y} ; \mathrm{B})$, and an older adult (71 y; C). a: myosin heavy chain-I (green) + laminin (red) + 4,6-diamidino-2-phenylindole (DAPI; blue) staining from serial crosssection of images (b-d); the marked area represents the same area as shown in frames b-d; b: CD56 (green) + laminin (red) + DAPI staining (blue); c: CD56 + DAPI staining; d: CD56 staining. Arrows indicate the satellite cells. Numbers indicate type I and II muscle fibers. Scale bars $=100 \mu \mathrm{m}$

After staining, digital images were captured using fluorescence microscopy (44). All image recordings and analyses were performed by an investigator blinded to subject coding. For the fiber typing slides, the number of muscle fibers, the mean fiber crosssectional area (CSA), the number of myonuclei, and the myonuclear domain (i.e. fiber $\mathrm{CSA} /$ number of myonuclei) were measured for type I and type II muscle fibers separately. For the satellite cell slides, fiber type was determined based on the serial fiber typing slides. Satellite cells were determined at the periphery of the muscle fiber and stained 
positive for both CD56 and DAPI (Fig. 1). The number of satellite cells per muscle fiber, the number of satellite cells per $\mathrm{mm}^{2}$ of muscle fiber, and the number of satellite cells relative to the total number of myonuclei (number of satellite cells / [number of myonuclei + number of satellite cells] ${ }^{*} 100 \%$ ) were determined for type I and type II muscle fibers separately. On average, $240 \pm 23$ type I and $182 \pm 11$ type II muscle fibers were analyzed for each subject, with a minimum of 100 fibers to determine satellite cell content in type I and II muscle fibers separately (25).

\section{Statistics}

All data are expressed as means \pm SD. To distinguish between changes occurring during normal childhood growth up to adulthood, and changes occurring throughout adulthood, separate analyses were performed on all muscle samples obtained from subjects aged 0-18y, and subjects aged $18 \mathrm{y}$ and over. Since the data were not normally distributed in the group 0-18 y, Spearman's rho $(\rho)$ was determined to assess the relationship between age and muscle fiber size and satellite cell content. To determine the relationship between age and muscle fiber size and satellite cell content in the adult cohort, Pearson correlation coefficients ( $r$ ) were calculated. Furthermore, differences between groups (i.e. young adult, older, and senescent subjects) were analyzed by one-way ANOVA. In case of significant differences, Tukey post hoc tests were performed to locate between-group differences. In addition, differences between type I and II muscle fibers (i.e. muscle fiber CSA, myonuclear content, and satellite cell content) were analyzed by paired samples t-tests in the young adult, older, and senescent groups separately. For the subset of subjects enrolled in the resistance type exercise training program, repeated measures ANOVA with 'time $x$ fiber type' interaction was performed. In case of significant interaction, paired samples t-tests were performed to assess changes over time and/or between type I and II muscle fibers. In addition, linear regression was performed to predict the changes in muscle fiber size. Age, baseline muscle fiber size, baseline satellite cell content, baseline myonuclear content, and the change in satellite cell content and myonuclear content were included as potential predictors. All analyses were performed using SPSS version 19.0 (Chicago, IL). An $\alpha$-level of 0.05 was used to determine statistical significance.

\section{RESULTS}

\section{Muscle fiber characteristics in children}

Type I muscle fiber percentage averaged $64 \pm 15 \%$ in muscle tissue obtained from children aged 0-18 y, and no change was observed with increasing age. Type I and II muscle fiber size increased substantially with age from 164 and $131 \mu \mathrm{m}^{2}$ at 1 week after birth, to 762 and $1001 \mu \mathrm{m}^{2}$ on average at age $1 \mathrm{y}$, to 6513 and $8659 \mu \mathrm{m}^{2}$ on average at age 18 $y$, respectively. In accordance, a positive correlation was observed between age and 
muscle fiber size for both type I $(\rho=0.96, P<0.001$ ), and type II muscle fibers $(\rho=0.91$, $P<0.001$; Fig. 2A). In line with the greater muscle fiber size, myonuclear content increased with age in both type I and type II muscle fibers during the first 18 years of life ( $\rho=0.89$ and $\rho=0.85$, respectively; $P<0.001$ ). The number of satellite cells per muscle fiber averaged $0.076 \pm 0.015$ (type I) and $0.076 \pm 0.023$ (type II) in the first year of life, and modestly increased from 0-18 y (type I: $\rho=0.62, P=0.014$; type II: $\rho=0.51, P=0.052$; Fig. $2 B)$. During the first year of life, the number of satellite cells relative to the total number of myonuclei averaged $12.3 \%$ (range: 9.4-20.9\%) and the number of satellite cells per $\mathrm{mm}^{2}$ of muscle fiber averaged 199 (range: 92-396). Interestingly, with increasing age in children, there was a substantial decline in the number of satellite cells relative to the total number of myonuclei both in type I ( $\rho=-0.84 ; P<0.001)$ and type II muscle fibers $(\rho=-0.88 ; P<0.001)$. In accordance, the number of satellite cells per $\mathrm{mm}^{2}$ of muscle fiber area showed an extensive reduction with increasing age in children (type I: $\rho=-$ 0.95; type II: $\rho=-0.95 ; P<0.001$; Fig. 2 C). Importantly, no differences were observed between type I and type II muscle fibers for muscle fiber size, myonuclear content, or satellite cell content in children aged 0-18 y.
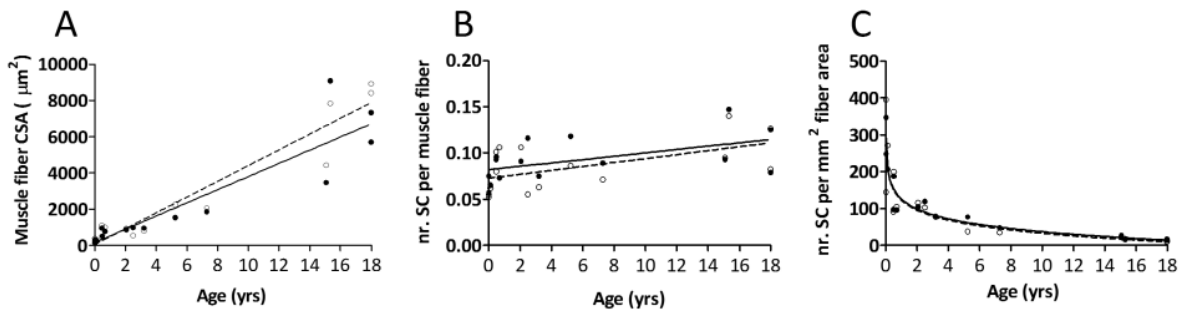

Figure 2 Scatter plots for children aged 0-18 y $(n=15)$, showing the correlation between age and (A) muscle fiber cross-sectional area (CSA); (B) the number of satellite cells (SC) per muscle fiber; and (C) the number of satellite cells per $\mathrm{mm}^{2}$ muscle fiber area. Type I: filled circles/solid line. Type II: open circles/dashed line. Lines represent the fitted regression (linear in A-B, logarithmic in C). Spearman rank correlation coefficients: A: $\rho$ $=0.96$ (type I; $P<0.001$ ) and $\rho=0.91$ (type II; $P<0.001$ ); $B: \rho=0.62$ (type I; $P=0.011$ ) and $\rho=0.51$ (type II; $P=0.052$ ); C: $\rho=-0.95$ (type I; $P<0.001$ ) and $\rho=-0.95$ (type II; $P<0.001$ )

\section{Muscle fiber type distribution and muscle fiber size in adult muscle}

Muscle fiber type composition was not different for older and senescent subjects when compared with the young adults ( $47 \pm 15$ and $48 \pm 11$ vs. $52 \pm 15 \%$ type II muscle fibers, respectively). However, the area percentage occupied by type II muscle fibers was significantly lower in older and senescent subjects when compared with the young adults ( $44 \pm 16$ and $43 \pm 13$ vs. $54 \pm 16 \%$, respectively; $P=0.001$ ).

Correlation analysis showed that type II muscle fiber size substantially declined with an increase in age $(r=-0.56, P<0.001$; Fig. $3 A)$. No such relationship was apparent for the type I muscle fibers. In the young adult subjects, muscle fiber size was significantly greater in type II vs. type I muscle fibers ( $P<0.001$; Fig. $4 \mathrm{~A})$. In contrast, in both the older 
and senescent subjects, muscle fiber size was significantly smaller in type II vs. type I muscle fibers ( $P<0.001$; Fig. 4A).
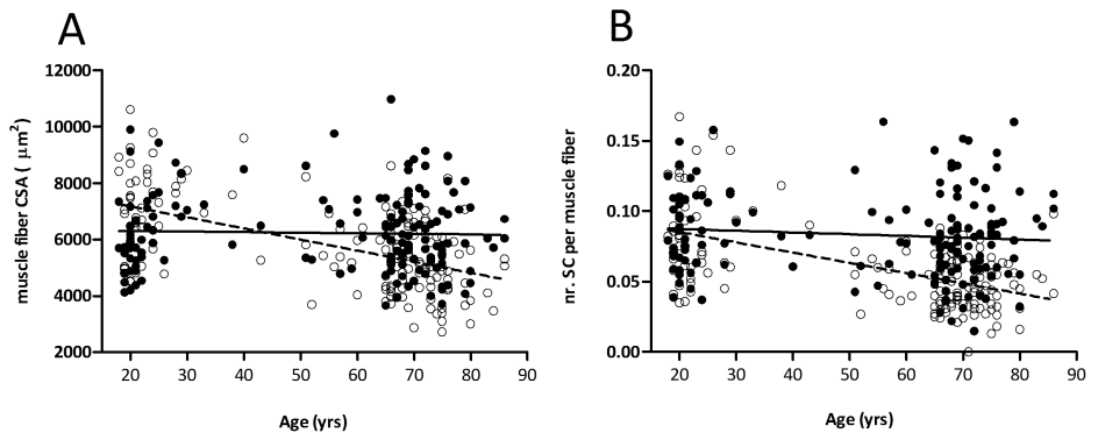

Figure 3 Scatter plots for adults aged 18-86 y $(n=152)$, showing the correlation between age and (A) muscle fiber cross-sectional area (CSA); and (B) the number of satellite cells (SC) per muscle fiber. Type I: filled circles/solid line. Type II: open circles/dashed line. Lines represent the fitted linear regression. Pearson correlation coefficients: A: $r=-0.033$ (type I; $P=0.682$ ) and $r=-0.56$ (type II; $P<0.001$ ); $\mathrm{B}: \mathrm{r}=-0.109$ (type I; $P=0.184$ ) and $r=-0.57$ (type II; $P<0.001$ )

\section{Myonuclear and satellite cell content in adult muscle}

In the young adult subjects, no differences were observed between type I and type II muscle fiber myonuclear content (Table 1). In the older and senescent subjects, muscle fiber myonuclear content was significantly lower in type II vs. type I muscle fibers $(P<0.001$; Table 1$)$. In addition, type II muscle fiber myonuclear content was lower in the senescent subjects when compared with the young adult $(P<0.001)$ and older subjects ( $P=0.002$; Table 1$)$. Whereas type I muscle fiber myonuclear domain did not differ between groups, type II muscle fiber myonuclear domain was smaller in the older subjects when compared with the young adults $(P<0.001$; Table 1$)$.

The correlation analysis revealed that an increase in age was associated with a reduction in type II muscle fiber satellite cell content ( $r=-0.57 ; P<0.001$; Fig. 3B). No such correlation was observed for the type I muscle fibers. In line with these data, type II muscle fiber satellite cell content expressed relative to the total number of myonuclei and per $\mathrm{mm}^{2}$ of muscle fiber area was substantially lower with an increase in age $(P<0.01 ;$ Table 1$)$. In the young adults, satellite cell content did not differ between type I and type II muscle fibers $(0.089 \pm 0.028$ vs. $0.085 \pm 0.033$ satellite cells per muscle fiber, respectively; Fig. 4B). However, in the older and senescent subjects muscle fiber satellite cell content was significantly lower in type II $(0.051 \pm 0.018$ and $0.045 \pm 0.019$, respectively) than in type I muscle fibers $(0.080 \pm 0.030$ and $0.081 \pm 0.032$, respectively; $P<0.001$; Fig. 4B). The latter was also apparent when satellite cell content was expressed relative to the total number of myonuclei and per $\mathrm{mm}^{2}$ of muscle fiber area $(P<0.05 ;$ Table 1$)$. 

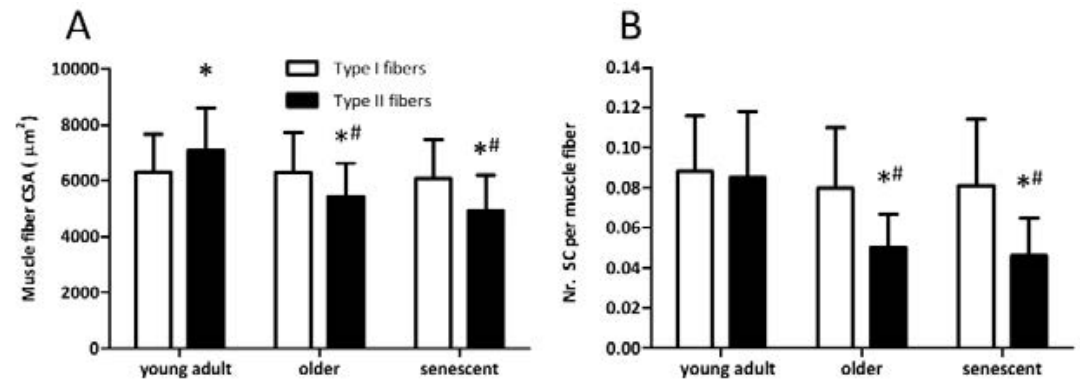

Figure 4 Skeletal muscle fiber (A) cross-sectional area (CSA), and (B) satellite cell (SC) content in young adult (18-49 y; $n=50)$, older (50-69 y; $n=53)$, and senescent subjects (70-86y; $n=49)$. Data represent means $\pm S D$. *: significantly different when compared with type I muscle fibers. \#: significantly different when compared with young adult subjects.

Table 1 Muscle fiber characteristics in adults

\begin{tabular}{ccccc}
\hline & $\begin{array}{c}\text { Fiber } \\
\text { type }\end{array}$ & $\begin{array}{c}\text { Young adult } \\
\mathrm{n}=50\end{array}$ & $\begin{array}{c}\text { Older } \\
\mathrm{n}=53\end{array}$ & $\begin{array}{c}\text { Senescent } \\
\mathrm{n}=49\end{array}$ \\
\hline Nuclei/fiber & I & $3.8 \pm 1.1$ & $4.0 \pm 1.0$ & $3.4 \pm 0.8^{\#}$ \\
& II & $3.7 \pm 1.1$ & $3.5 \pm 1.0+$ & $2.8 \pm 0.7^{* \#+}$ \\
Nuclear domain $\left(\mu \mathrm{m}^{2}\right)$ & I & $1775 \pm 465$ & $1655 \pm 488$ & $1824 \pm 397$ \\
& II & $2002 \pm 425$ & $1655 \pm 475^{*}$ & $1822 \pm 415$ \\
$\mathrm{SC} / \mathrm{mm}^{2}$ & I & $2.5 \pm 1.2$ & $2.1 \pm 1.0$ & $2.5 \pm 1.0$ \\
& II & $2.4 \pm 1.0$ & $1.5 \pm 0.6 *+$ & $1.6 \pm 0.7^{*+}$ \\
& I & $14.3 \pm 4.8$ & $12.7 \pm 3.9$ & $13.5 \pm 5.3$ \\
\hline
\end{tabular}

Data represent means \pm SD. SC: satellite cell. SC\%: the number of satellite cells as a percentage of the total number of myonuclei. *significantly different compared with young adults. " significantly different compared with older. †significantly different compared with Type I (within groups)

\section{Resistance type exercise training}

In response to 12 weeks of resistance type exercise training, type II muscle fiber size had increased by $20 \pm 21 \%$ (Fig. $5 A$ ). The latter was significantly greater than the $9 \pm 22 \%$ increase in type I muscle fiber size ( $P<0.001$ for 'time $x$ fiber type' interaction). A significant 'time $x$ fiber type' interaction $(P<0.001)$ showed that the increase in type II muscle fiber size was accompanied by an increase in type II muscle fiber myonuclear content (from $3.0 \pm 0.9$ to $3.5 \pm 1.1 ; P=0.002$ ), whereas no such change was observed in type I muscle fiber myonuclear content $(P=0.216)$. No changes were observed in myonuclear domain size in either type I or type II muscle fibers following resistance type exercise training (data not shown). 

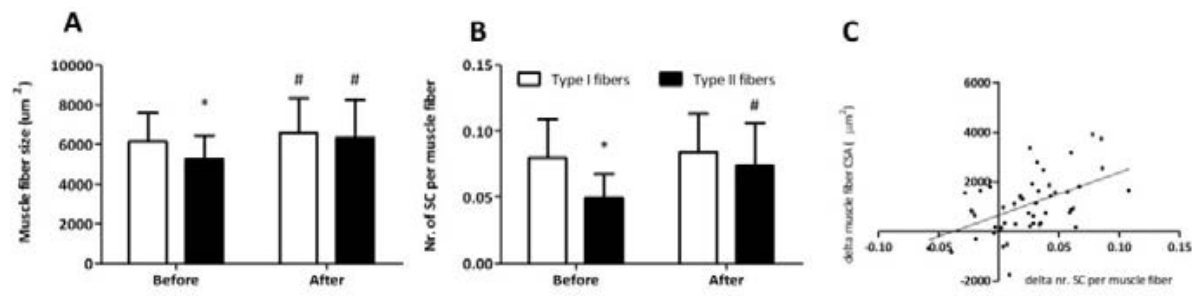

Figure 5 Skeletal muscle fiber (A) cross-sectional area (CSA), and (B) satellite cell (SC) content before and after 12 weeks of resistance type exercise training in 51 older $(71 \pm 6$ y) subjects. C: linear regression showing the relation between the change in type II muscle fiber SC content and the change in muscle fiber CSA following the $12 \mathrm{wk}$ training program. Data represent means $\pm S D$. * : significantly different when compared with type I muscle fibers $(P<0.001)$. \#: significantly different when compared with values before training $(P<0.05)$.

For all satellite cell variables, a significant 'time $\mathrm{x}$ fiber type' interaction was observed. In contrast to the type I muscle fibers, type II muscle fibers showed a substantial increase in satellite cell content from $0.049 \pm 0.018$ satellite cells per fiber at baseline to $0.074 \pm 0.032$ satellite cells per fiber following 12 weeks of resistance type exercise training $(P<0.001 ;$ Fig. 5B). In accordance, type II muscle fiber satellite cell content significantly increased when expressed as the number of satellite cells relative to the total number of myonuclei (from $1.7 \pm 0.8$ to $2.2 \pm 1.0 \%$; $P=0.001$ ), as well as the number of satellite cells per $\mathrm{mm}^{2}$ of muscle fiber area (from 9.6 \pm 3.9 to $12.0 \pm 5.3$ satellite cells per $\left.\mathrm{mm}^{2} ; \mathrm{P}=0.003\right)$. No such changes were observed in type I muscle fibers. Whereas at baseline, both muscle fiber size and muscle fiber satellite cell content were significantly lower in type II vs. type I muscle fibers, these differences were no longer apparent after 3 months of supervised resistance type exercise training (Fig. 5).

Interestingly, linear regression analysis showed that a greater increase in both type II muscle fiber satellite cell content and myonuclear content were strongly associated with a greater increase in type II muscle fiber size in response to training. In order of the strength of the relations, the following parameters were shown to significantly predict the increase in type II muscle fiber size (total $\mathrm{R}=0.73$ ): 1 ) change in type II muscle fiber satellite cell content (standardized $B=0.44 ; P=0.001 ;$ Fig. $5 C$ ); 2 ) change in type II muscle fiber myonuclear content (standardized $B=0.44 ; P=0.004$ ); and 3 ) baseline myonuclear content (standardized $B=0.30 ; P=0.030$ ). See Online Resource 1 for regression plots of all 3 predictors.

\section{Discussion}

In the present study, we assessed type I and type II muscle fiber size and satellite cell content in humans aged 1 week through 86 years. We show that during childhood, both type I and II muscle fiber size increase with a concomitant increase in myonuclear content. Throughout adulthood, there is a specific decline in type II muscle fiber size in the 
vastus lateralis muscle with increasing age. In this large cohort with ages ranging over the adult human lifespan, we report that type II muscle fiber atrophy with aging is accompanied by a muscle fiber type-specific decline in satellite cell content. Furthermore, we show that prolonged resistance type exercise training can fully reverse the agerelated reduction in type II muscle fiber size and satellite cell content.

By virtue of their stem cell properties, satellite cells are essential for skeletal muscle fiber growth, repair and regeneration throughout human life (15). In the present study, we obtained muscle tissue from subjects aged 0-86 y, allowing us to assess differences in muscle fiber type-specific satellite cell content throughout the entire human lifespan. In muscle tissue samples obtained from children aged 0-18 y, we observed that muscle fiber satellite cell content remains fairly constant from birth towards adulthood (Fig. 2B). However, when expressed relative to muscle fiber area, satellite cell content shows an almost 30 -fold decline in subjects aged 0 through 18 years (Fig. $2 \mathrm{C}$ ). Of course, there is not much data on muscle fiber characteristics in such young children. Previous work in both animals $(5,7)$ and humans $(38,42)$ merely assessed satellite cell content as a percentage of the total number of myonuclei, and reported a decline in satellite cell content from birth towards adulthood. We now extend on these findings by showing that such a decline is only observed when satellite cell content is expressed relative to muscle fiber size and/or myonuclear content. Furthermore, we report that during normal childhood growth, no major differences are apparent between type I and II muscle fibers for muscle fiber size and satellite cell content. The greater satellite cell content in very young children (i.e. expressed relative to muscle fiber size and/or myonuclear content) is likely essential to provide new myonuclei to allow substantial muscle hypertrophy during childhood growth $(31,43)$. In support, we report a 30 to 40 fold increase in type I and type II muscle fiber size during the first 18 years of life (Figure 2A), with a concomitant increase in the number of myonuclei per muscle fiber.

Over the adult lifespan, there is a gradual loss of skeletal muscle mass with increasing age (16). With large differences existing in the function and morphology of different muscles, age-related changes in muscle fiber characteristics have also been shown to be markedly different between, for example, limb and jaw muscles $(30,35,42)$. In the present study, we show that between the 3rd and 9th decade of life, there is an approximate $30-35 \%$ reduction in type II muscle fiber size in the vastus lateralis muscle (Fig. 3A). Strikingly, from the current cross-sectional analysis there is absolutely no indication of any decline in type I muscle fiber size with increasing age. Whereas type II muscle fiber size in vastus lateralis generally exceeds type I muscle fiber size in a young adult population, the opposite holds true at a more advanced age (Fig. 4A). These data confirm previous suggestions reporting specific type II muscle fiber atrophy with aging $(20,21)$. This underlines the importance of muscle fiber type-specific characterization of skeletal muscle tissue, as type-specific alterations may remain undetected when using mixed muscle fiber analyses. Apart from type-specific modifications in muscle fiber size, changes in MHC composition have been reported throughout life. Previous 
work has shown substantial MHC-coexpression in old vastus lateralis muscle (1), old masseter muscle (30), and young masseter but not biceps brachii muscle (32). Furthermore, a shift towards a fast and fetal phenotype was observed in old masseter muscle (30), and a shift towards a slower phenotype in the old biceps brachii. $(19,30)$, and vastus lateralis muscle (19). These previous studies have shown that muscle phenotypic modifications throughout life are both muscle and region specific, and different findings may be observed when using e.g. immunohistochemistry vs. gel electrophoresis $(19,30)$. Using immunohistochemistry with a single MHC antibody in the present study, we were unable to detect any changes in MHC composition throughout life. It remains to be established to what extent age-related transitions in MHC composition and/or coexpression are associated with changes in muscle fiber size and/or satellite cell content.

To investigate the proposed relationship between age-related muscle atrophy and satellite cell content, we previously compared muscle fiber characteristics between a small group of healthy young $(n=8)$ and elderly men $(n=8)$. That study was the first to report that senescent muscle is characterized by a selective type II muscle fiber specific decline in satellite cell content (46). To further investigate these proposed fiber typespecific changes in satellite cell content with aging, we obtained muscle biopsy samples from 152 adults with ages ranging from 18 through 86 years. The present work extends on our previous observations by showing that increasing age is associated with a type II muscle fiber type-specific decline in satellite cell content, whereas no such correlation is observed for the type I fibers (Fig. 3B). In the past, small differences have been reported for satellite cell numbers assessed by $\operatorname{CD} 56$ compared with Pax-7 $(23,25,29)$. This discrepancy is likely attributed to differences in staining profile of these markers and/or their differential expression throughout the cell cycle (related to biopsy sampling time points). Therefore, it is essential to explicitly describe the procedures for muscle biopsy collection and satellite cell determination. In doing so, we (46) and others $(23,29)$ have shown that the majority of satellite cells (i.e. $>95 \%$ ) are both Pax-7 and CD56-positive, with no differences between young and elderly. As such, the decline in satellite cell content appears a genuine hallmark of aging and is unlikely affected by the specific marker chosen to identify satellite cells. Given the cross-sectional nature of our data, we are unable to determine whether the observed decline in satellite cell content may represent either a cause or simply a consequence of muscle fiber atrophy. However, previous studies have suggested that satellite cell pool size may play an important role in skeletal muscle maintenance and growth $(34,39)$. As such, the current findings strongly support our beliefs that the decline in satellite cell content represents a key factor in the etiology of muscle atrophy with aging.

Interestingly, we also observed a significant decline in myonuclear content and myonuclear domain size with aging, specifically in the type II muscle fibers (Table 1). Whereas recent studies have questioned a role for myonuclear loss in skeletal muscle atrophy, a reduction in myonuclear domain size with aging has been reported more consistently 
$(8,17)$. This finding may be associated with a reduced capacity of each myonucleus to sustain cellular processes for a certain volume of cytoplasm. However, the exact relations between changes in satellite cell pool size, changes in myonuclear content and domain size, and their contribution to type II muscle fiber atrophy with aging remain to be fully established.

To further study the proposed relation between changes in muscle fiber satellite cell content and muscle fiber size, a subset of 51 elderly subjects ( $71 \pm 6$ y) were subjected to a supervised resistance type exercise training program. After 12 weeks of resistance type exercise training, we observed a type II muscle fiber specific increase in satellite cell content and myonuclear content (Fig. 5). Even at a more advanced age, skeletal muscle tissue can still induce satellite cell proliferation and allows the subsequent incorporation of their differentiated progeny as newly formed myonuclei. This likely allowed the substantial $20 \%$ increase in type II muscle fiber size following 12 weeks of training. Interestingly, a modest $9 \%$ increase in type I muscle fiber size was also reported. The latter, however, was not associated with an increase in satellite cell content. Previous studies have indicated that resistance type exercise training can reverse the age-related decline in type II muscle fiber size $(26,40,44,47)$. Furthermore, it has been suggested that the incorporation of newly derived myonuclei is necessary to subsequently allow substantial muscle fiber hypertrophy $(6,34)$. Therefore, we hypothesized that resistance type exercise training would increase type II muscle fiber satellite cell content, thereby facilitating the incorporation of newly formed myonuclei and, subsequently, allowing type II muscle fibers to hypertrophy. By subjecting a large number of elderly men to 12 weeks of training, we were able to assess which factors would predict the extent of muscle fiber hypertrophy. We observed that elderly subjects that showed a greater increase in type II muscle fiber satellite cell content also showed a greater increase in type II muscle fiber size. In addition to the increase in satellite cell content, both the increase in myonuclear content, as well as myonuclear content at baseline were shown to be predictive of the increase in type II muscle fiber size. In contrast with the earlier work by Petrella et al. (34), we did not observe an association between baseline satellite cell content and the potential for hypertrophy. It remains to be determined to what extent this could be explained by differences in study design (i.e. age and gender of subjects, and mixed vs. muscle fiber type-specific analyses). Nonetheless, in agreement with Petrella et al. (34), we provide further support for the idea that an increase in satellite cell and myonuclear content play a key role in determining an individual's potential for skeletal muscle fiber hypertrophy $(41,50)$. It was recently shown that under experimental conditions, muscle hypertrophy can occur without a satellite cell-induced increase in myonuclear content (28). Interestingly though, the same authors provide evidence to support that in normal, non-satellite cell depleted muscle, overload induced hypertrophy is associated with fusion of satellite cell-derived myonuclei (28). We argue that in a normal, physiological situation, the induction of satellite 
cells and the subsequent incorporation of new myonuclei are prerequisite for substantial muscle hypertrophy.

In the present study, muscle tissue collected from different muscles in children undergoing surgery was only included in the analysis when no sign of hypoxia was detected. In support of this strategy, our data on muscle fiber growth and distribution patterns in children are in line with previous findings $(4,31)$. Nonetheless, caution should be taken when interpreting and translating the children's data toward other muscle (groups), as large heterogeneity in muscle fiber characteristics exists between different muscles (32). The latter includes the vastus lateralis muscle, from which biopsies were collected in all adult subjects. This muscle is easily accessible and, more importantly, plays a major role with regard to age-related functional impairments $(13,48)$. Therefore, the substantial reduction in type II muscle fiber satellite cell content and muscle fiber size with increasing age is of great clinical importance. Yet, with different muscles aging differently $(30,35,42)$, fiber type-specific changes in muscle fiber size and satellite cell content remain to be examined throughout the human body. Furthermore, Figure 3 clearly shows that age alone does not fully explain the large variability in muscle fiber size and satellite cell content between individuals. Habitual physical activity level has been identified as a strong predictor of muscle mass and strength, independent of age (2). Differences in physical activity level likely contribute to the large inter-subject variability in muscle fiber size and satellite cell content. The latter is supported by the observation that resistance type exercise training can fully reverse the age-associated reduction in type II muscle fiber size and satellite cell content. Clearly, skeletal muscle tissue retains a remarkable degree of plasticity even at a more advanced age. Consequently, there is ample opportunity for future exercise, nutritional, and pharmacological interventions to prevent or attenuate age-related muscle loss. Given the fiber type-specific changes in muscle tissue characteristics with aging, it is evident that effective interventions should specifically target type II muscle fiber atrophy.

We conclude that from birth to adulthood in humans, muscle fiber size increases tremendously with no major changes in the number of satellite cells per muscle fiber, and no differences between type I and II muscle fibers. Throughout the adult lifespan, aging is accompanied by a specific decline in type II muscle fiber satellite cell content. The specific reduction in type II muscle fiber satellite cell content likely represents a key factor responsible for specific type II muscle fiber atrophy with aging. This age-related muscle atrophy can be effectively reversed by prolonged resistance type exercise training. Resistance type exercise training increases type II muscle fiber satellite cell content, facilitating the incorporation of new myonuclei, thus allowing type II muscle fiber hypertrophy. 


\section{REFERENCES}

1. Andersen JL, Terzis G, and Kryger A. Increase in the degree of coexpression of myosin heavy chain isoforms in skeletal muscle fibers of the very old. Muscle Nerve 22: 449-454, 1999.

2. Baumgartner RN, Waters DL, Gallagher D, Morley JE, and Garry PJ. Predictors of skeletal muscle mass in elderly men and women. Mech Ageing Dev 107: 123-136, 1999.

3. Bergstrom J. Percutaneous needle biopsy of skeletal muscle in physiological and clinical research. Scand J Clin Lab Invest 35: 609-616, 1975.

4. Brooke $\mathrm{MH}$, and Engel WK. The histographic analysis of human muscle biopsies with regard to fiber types. 4. Children's biopsies. Neurology 19: 591-605, 1969.

5. Brown SC, and Stickland NC. Satellite cell content in muscles of large and small mice. J Anat 183 (Pt 1): 91-96, 1993.

6. Bruusgaard JC, Johansen IB, Egner IM, Rana ZA, and Gundersen K. Myonuclei acquired by overload exercise precede hypertrophy and are not lost on detraining. Proc Natl Acad Sci U S A 107: 15111-15116, 2010.

7. Cardasis CA, and Cooper GW. An analysis of nuclear numbers in individual muscle fibers during differentiation and growth: a satellite cell-muscle fiber growth unit. J Exp Zool 191: 347-358, 1975.

8. Cristea A, Qaisar R, Edlund PK, Lindblad J, Bengtsson E, and Larsson L. Effects of aging and gender on the spatial organization of nuclei in single human skeletal muscle cells. Aging Cell 9: 685-697, 2010.

9. Delhaas T, Van der Meer SF, Schaart G, Degens H, and Drost MR. Steep increase in myonuclear domain size during infancy. Anat Rec (Hoboken) 296: 192-197, 2013.

10. Dhawan J, and Rando TA. Stem cells in postnatal myogenesis: molecular mechanisms of satellite cell quiescence, activation and replenishment. Trends Cell Biol 15: 666-673, 2005.

11. Dreyer HC, Blanco CE, Sattler FR, Schroeder ET, and Wiswell RA. Satellite cell numbers in young and older men 24 hours after eccentric exercise. Muscle Nerve 33: 242-253, 2006.

12. Evans W. Functional and metabolic consequences of sarcopenia. J Nutr 127: 998S-1003S, 1997.

13. Fiatarone MA, Marks EC, Ryan ND, Meredith CN, Lipsitz LA, and Evans WJ. High-intensity strength training in nonagenarians. Effects on skeletal muscle. Jama 263: 3029-3034, 1990.

14. Frontera WR, Meredith CN, O'Reilly KP, Knuttgen HG, and Evans WJ. Strength conditioning in older men: skeletal muscle hypertrophy and improved function. J Appl Physiol 64: 1038-1044, 1988.

15. Hawke TJ, and Garry DJ. Myogenic satellite cells: physiology to molecular biology. J Appl Physiol 91: $534-$ $551,2001$.

16. Janssen I, Heymsfield SB, Wang ZM, and Ross R. Skeletal muscle mass and distribution in 468 men and women aged 18-88 yr. J Appl Physiol 89: 81-88, 2000.

17. Kadi F, Charifi N, Denis C, and Lexell J. Satellite cells and myonuclei in young and elderly women and men. Muscle Nerve 29: 120-127, 2004.

18. Kadi F, Charifi N, Denis C, Lexell J, Andersen JL, Schjerling P, Olsen S, et al. The behaviour of satellite cells in response to exercise: what have we learned from human studies? Pflugers Arch 451: 319-327, 2005.

19. Klitgaard H, Zhou M, Schiaffino S, Betto R, Salviati G, and Saltin B. Ageing alters the myosin heavy chain composition of single fibres from human skeletal muscle. Acta Physiol Scand 140: 55-62, 1990

20. Larsson L, Sjodin B, and Karlsson J. Histochemical and biochemical changes in human skeletal muscle with age in sedentary males, age 22--65 years. Acta Physiol Scand 103: 31-39, 1978.

21. Lexell J, Taylor CC, and Sjostrom M. What is the cause of the ageing atrophy? Total number, size and proportion of different fiber types studied in whole vastus lateralis muscle from 15- to 83-year-old men. J Neurol Sci 84: 275-294, 1988.

22. Lindle RS, Metter EJ, Lynch NA, Fleg JL, Fozard JL, Tobin J, Roy TA, et al. Age and gender comparisons of muscle strength in 654 women and men aged 20-93 yr. J Appl Physiol 83: 1581-1587, 1997.

23. Lindstrom $M$, and Thornell LE. New multiple labelling method for improved satellite cell identification in human muscle: application to a cohort of power-lifters and sedentary men. Histochem Cell Biol 132: 141-157, 2009. 
24. Mackey AL, Esmarck B, Kadi F, Koskinen SO, Kongsgaard M, Sylvestersen A, Hansen JJ, et al. Enhanced satellite cell proliferation with resistance training in elderly men and women. Scand J Med Sci Sports 17: 34-42, 2007.

25. Mackey AL, Kjaer M, Charifi N, Henriksson J, Bojsen-Moller J, Holm L, and Kadi F. Assessment of satellite cell number and activity status in human skeletal muscle biopsies. Muscle Nerve 40: 455-465, 2009.

26. Martel GF, Roth SM, Ivey FM, Lemmer JT, Tracy BL, Hurlbut DE, Metter EJ, et al. Age and sex affect human muscle fibre adaptations to heavy-resistance strength training. Exp Physiol 91: 457-464, 2006.

27. Mauro A. Satellite cell of skeletal muscle fibers. J Biophys Biochem Cytol 9: 493-495, 1961.

28. McCarthy JJ, Mula J, Miyazaki M, Erfani R, Garrison K, Farooqui AB, Srikuea R, et al. Effective fiber hypertrophy in satellite cell-depleted skeletal muscle. Development 138: 3657-3666, 2011.

29. McKay BR, Toth KG, Tarnopolsky MA, and Parise G. Satellite cell number and cell cycle kinetics in response to acute myotrauma in humans: immunohistochemistry versus flow cytometry. J Physiol 588: 3307-3320, 2010.

30. Monemi M, Kadi F, Liu JX, Thornell LE, and Eriksson PO. Adverse changes in fibre type and myosin heavy chain compositions of human jaw muscle vs. limb muscle during ageing. Acta Physiol Scand 167: 339345, 1999.

31. Oertel G. Morphometric analysis of normal skeletal muscles in infancy, childhood and adolescence. An autopsy study. J Neurol Sci 88: 303-313, 1988.

32. Osterlund C, Lindstrom M, Thornell LE, and Eriksson PO. Remarkable heterogeneity in myosin heavychain composition of the human young masseter compared with young biceps brachii. Histochem Cell Biol 138: 669-682, 2012.

33. Petrella JK, Kim JS, Cross JM, Kosek DJ, and Bamman MM. Efficacy of myonuclear addition may explain differential myofiber growth among resistance-trained young and older men and women. Am J Physiol Endocrinol Metab 291: E937-946, 2006.

34. Petrella JK, Kim JS, Mayhew DL, Cross JM, and Bamman MM. Potent myofiber hypertrophy during resistance training in humans is associated with satellite cell-mediated myonuclear addition: a cluster analysis. J Appl Physiol 104: 1736-1742, 2008.

35. Renault V, Thornell LE, Eriksson PO, Butler-Browne G, and Mouly V. Regenerative potential of human skeletal muscle during aging. Aging Cell 1: 132-139, 2002.

36. Roth SM, Martel GF, Ivey FM, Lemmer JT, Metter EJ, Hurley BF, and Rogers MA. Skeletal muscle satellite cell populations in healthy young and older men and women. Anat Rec 260: 351-358, 2000.

37. Roth SM, Martel GF, Ivey FM, Lemmer JT, Tracy BL, Metter EJ, Hurley BF, et al. Skeletal muscle satellite cell characteristics in young and older men and women after heavy resistance strength training. J Gerontol A Biol Sci Med Sci 56: B240-247, 2001.

38. Schmalbruch $\mathrm{H}$, and Hellhammer $\mathrm{U}$. The number of satellite cells in normal human muscle. Anat Rec 185: 279-287, 1976.

39. Shefer G, Van de Mark DP, Richardson JB, and Yablonka-Reuveni Z. Satellite-cell pool size does matter: Defining the myogenic potency of aging skeletal muscle. Dev Biol 294: 50-66, 2006.

40. Singh MA, Ding W, Manfredi TJ, Solares GS, O'Neill EF, Clements KM, Ryan ND, et al. Insulin-like growth factor I in skeletal muscle after weight-lifting exercise in frail elders. Am J Physiol 277: E135-143, 1999.

41. Snijders T, Verdijk LB, and van Loon LJ. The impact of sarcopenia and exercise training on skeletal muscle satellite cells. Ageing Res Rev 8: 328-338, 2009.

42. Thornell LE, Lindstrom M, Renault V, Mouly V, and Butler-Browne GS. Satellite cells and training in the elderly. Scand J Med Sci Sports 13: 48-55, 2003.

43. Vassilopoulos D, Lumb EM, and Emery AE. Karyometric changes in human muscle with age. Eur Neurol 16: 31-34, 1977.

44. Verdijk LB, Gleeson BG, Jonkers RA, Meijer K, Savelberg HH, Dendale P, and van Loon LJ. Skeletal muscle hypertrophy following resistance training is accompanied by a fiber type-specific increase in satellite cell content in elderly men. J Gerontol A Biol Sci Med Sci 64: 332-339, 2009. 
45. Verdijk LB, Jonkers RA, Gleeson BG, Beelen M, Meijer K, Savelberg HH, Wodzig WK, et al. Protein supplementation before and after exercise does not further augment skeletal muscle hypertrophy after resistance training in elderly men. Am J Clin Nutr 89: 608-616, 2009.

46. Verdijk LB, Koopman R, Schaart G, Meijer K, Savelberg HH, and van Loon L. Satellite cell content is specifically reduced in type II skeletal muscle fibers in the elderly. Am J Physiol Endocrinol Metab 292: E151-157, 2007.

47. Verney J, Kadi F, Charifi N, Feasson L, Saafi MA, Castells J, Piehl-Aulin K, et al. Effects of combined lower body endurance and upper body resistance training on the satellite cell pool in elderly subjects. Muscle Nerve 38: 1147-1154, 2008.

48. Visser M, Kritchevsky SB, Goodpaster BH, Newman AB, Nevitt M, Stamm E, and Harris TB. Leg muscle mass and composition in relation to lower extremity performance in men and women aged 70 to 79 : the health, aging and body composition study. J Am Geriatr Soc 50: 897-904, 2002.

49. Zammit PS, Golding JP, Nagata Y, Hudon V, Partridge TA, and Beauchamp JR. Muscle satellite cells adopt divergent fates: a mechanism for self-renewal? J Cell Biol 166: 347-357, 2004.

50. Zammit PS, Partridge TA, and Yablonka-Reuveni Z. The skeletal muscle satellite cell: the stem cell that came in from the cold. J Histochem Cytochem 54: 1177-1191, 2006. 


\section{CHAPTER 3}

\section{Muscle disuse atrophy is not accompanied by changes in skeletal muscle satellite cell content}

Tim Snijders

Benjamin T. Wall

Marlou L Dirks Joan M.G. Senden

Fred Hartgens

John Dolmans

Mario Losen

Lex B. Verdijk

Luc J.C. van Loon 


\section{ABSTRACT}

Introduction: Muscle disuse leads to a considerable loss of skeletal muscle mass and strength. However, the cellular mechanisms underlying disuse-induced muscle fiber atrophy remain to be elucidated. Therefore, we assessed the impact of muscle disuse on quadriceps muscle cross-sectional area (CSA), muscle fiber size and satellite cell content, and associated myocellular signaling pathways.

Methods: Twelve healthy, young ( $24 \pm 1$ y) men were subjected to 2 wks of one-legged knee immobilization via a full leg cast. Before and immediately after the immobilization period and after six weeks of natural rehabilitation, muscle strength (one-repetition maximum), muscle cross-sectional area (single slice CT-scan), and muscle fiber type characteristics (muscle biopsies) were assessed. Protein and/or mRNA expression of key genes (i.e. MyoD, myogenin and myostatin) in the satellite cell regulatory pathways were determined using Western blotting and RT-PCR (real time-PCR analyses, respectively.

Results: Quadriceps CSA declined following immobilization by $8 \pm 2 \%(P<0.05)$. In line, both type I and type II muscle fiber size decreased by $7 \pm 3 \%$ and $13 \pm 4 \%$, respectively $(P<0.05)$. No changes were observed in satellite cell content following immobilization in either type I or type II muscle fibers. Muscle myogenin mRNA expression had doubled $(P<0.05)$ while myostatin protein expression had decreased by $30 \pm 9 \%(P<0.05)$ following immobilization. Muscle mass and strength returned to baseline values within six weeks of recovery without any specific rehabilitative program.

Conclusion: Two weeks of muscle disuse leads to considerable loss of skeletal muscle mass and strength. The loss of muscle mass is attributed to both type I and type II muscle fiber atrophy, and is not accompanied by a decline in satellite cell content. 


\section{INTRODUCTION}

Sarcopenia is defined as the gradual loss of skeletal muscle mass with aging. On the muscle fiber level, this age-related loss of muscle mass is characterized by type II muscle fiber specific atrophy $(32,38,48)$. In addition, we $(47-49)$, as well as others $(26,50)$, have shown that type II muscle fiber atrophy in senescent muscle is accompanied by a type II muscle fiber type specific decline in the number of skeletal muscle stem cells, also known as satellite cells. Satellite cells represent the sole source for the formation of new myonuclei (30). Accordingly, these stem cells are thought to play a key role in skeletal muscle growth and regeneration and, as such, have been implicated as a key regulator of skeletal muscle mass maintenance $(14,38)$.

In line with the age-related changes in muscle fiber type specific satellite cell content, we have recently shown in a long-term model of skeletal muscle disuse (spinal cord injury), that severe atrophy of both type I and II muscle fibers is also associated with a substantially lower number of satellite cells in both fiber types (46). Yet, given the cross-sectional nature of these data, it remains unknown whether a decline in the number of skeletal muscle satellite cells could be a cause or simply a consequence of muscle fiber atrophy. Alternative models that have regularly been used to study the underlying mechanisms of skeletal muscle disuse atrophy are short-term lower or upper limb immobilization $(10,12,17,19,40,41,53)$. These models allow the assessment of skeletal muscle atrophy in a longitudinal study design. However, the rate of muscle mass loss has been show to differ between lower and upper limb immobilization. As reviewed by Wall et al. (52), the rate of muscle mass loss is found to be much slower during upper limb or hand immobilization compared with the lower limb immobilization. As such, lower limb immobilization would be a more feasible model to study the impact of disuse atrophy on muscle fiber characteristics (52). Lower limb immobilization can be achieved by a number of methods i.e. unilateral lower limb suspension (ULLS) $(6,12,42)$, plastic knee brace $(5,11)$, or full leg cast $(18,40,41,45)$. In contrast to unilateral lower limb suspension (ULLS) and brace immobilization, a plaster cast will result in the most severe local physical inactivity, and as such will yield the most robust physical inactivity induced reduction of muscle mass within a short time period. Muscle quadriceps cross-sectional area (CSA) has been reported to decrease up to $20 \%$ in response to 10-28 days of lower limb immobilization $(11,15,43,45)$. In agreement, a reduction in muscle fiber size has been detected in type $\mathrm{I}$, type $\mathrm{II}$, or mixed muscle fiber types in healthy young men after 10-42 days of limb immobilization $(4,15,16,45,55)$. However, it remains unknown whether disuse atrophy is also associated with changes in satellite cell content and/or associated molecular signaling. Such information may reveal further insight into the potential role of satellite cells in disuse induced skeletal muscle fiber atrophy. Therefore, in the present study we subjected 12 healthy, young males to a 2 week period of one-legged knee immobilization by means of a full leg cast, and collected muscle biopsies before and immediately after the immobilization period, 
as well as a final biopsy 6 weeks after immobilization to determine the course of natural recovery. We hypothesized that skeletal muscle disuse would lead to muscle fiber type specific atrophy that is associated with a fiber type specific decline in satellite cell content.

\section{Methods}

\section{Subjects}

Twelve, healthy young men ( $24 \pm 1 \mathrm{y} ; 83 \pm 3 \mathrm{~kg} ; 1.82 \pm 0.02 \mathrm{~m}$ ) were recruited to participate in the present study. Subjects were informed about the nature and risks of the experimental procedures before their written consent was obtained. The study was approved by the Medical Ethical Committee of the Maastricht University Medical Centre+, and complied with the guidelines set out in the Declaration of Helsinki. The current study was part of a larger project studying the impact of disuse atrophy on muscle metabolism (51). Subjects were screened to exclude any person with lower limb or back injuries sustained within a year prior to beginning the study, a (family) history of thrombosis, cardiovascular disease, or hemostatic disorders. In addition, subjects with musculoskeletal and/or orthopedic disorders which may compromise the subjects' ability to walk with crutches were excluded. After inclusion, subjects performed a familiarization trial to become experienced with the strength testing equipment. Proper lifting technique was demonstrated and then practiced by the subjects for the lowerlimb single-leg leg-extension exercises. Subsequently, maximal strength (one-repetition maximum, or $1 \mathrm{RM}$ ) was estimated by using the multiple repetitions testing procedure during two separate visits (25).

\section{Protocol}

All subjects participated in two pre-immobilization test days, separated by at least 7 days. During the first visit, body weight was measured with a digital balance with an accuracy of $0.1 \mathrm{~kg}$ (SECA GmbH, Hamburg, Germany) and body composition (fat and fat-free mass) was determined by Dual Energy X-Ray Absorptiometry scan (DEXA; Hologic Inc., Bedford, USA). Lean mass and percentage body fat were determined on a whole body level and for specific regions (e.g. trunk and legs). Single slice CT-scans (IDT 8000; Phillips Medical Systems, the Netherlands) at the level of mid-thigh were performed to determine (anatomical) CSA of the whole limb muscle and quadriceps femoris muscle of both legs, as described previously (23). On the second pre-immobilization test day, a muscle biopsy was taken from the vastus lateralis muscle. Next, subjects' 1RM was determined (25) for each leg separately. After warming up, the load was set at $95 \%$ of the estimated 1 RM from the screening visit, and increased after each successful lift until failure. Five min rest periods were allowed between lifts. A repetition was 
considered valid when the subject used proper form and was able to complete the entire lift in a controlled manner without assistance.

At least four days after the muscle biopsy sampling, one leg was immobilized by means of a plaster cast. After the $14 \mathrm{~d}$ immobilization period subjects reported back to the university and the plaster cast was removed. Immediately after removal of the cast, and 6 weeks after natural recovery, a second and third muscle biopsy were taken from the (previously) immobilized leg, respectively. In addition, all measurements (i.e. body weight, DEXA-scan, CT-scan, leg volume, and 1RM strength test) were repeated one day and 6 weeks after cast removal.

\section{Muscle biopsy}

Muscle biopsies were obtained from the middle region of the vastus lateralis muscle 15 $\mathrm{cm}$ above the patella and approximately $2 \mathrm{~cm}$ away from the fascia by means of the percutaneous needle biopsy technique described by Bergström et al. (3). All muscle biopsies were taken from the same leg. Each subsequent biopsy was spaced by $1-2 \mathrm{~cm}$, and the order of distal, middle and proximal incision was randomized to minimize any bias of the previous biopsy. Muscle biopsies were carefully freed from any visible fat and blood, embedded in Tissue-Tek (Sakura Finetek Europe B.V., Zoeterwoude, the Netherlands), and rapidly frozen in liquid nitrogen cooled isopentane and stored at 80 ㄷ $\mathrm{C}$ for subsequent biochemical and histochemical analysis.

\section{Leg immobilization}

One leg was immobilized by means of a full leg plaster cast. The cast was applied on the same leg from which the muscle biopsies were taken. The circular cast reached from 10 $\mathrm{cm}$ above the ankle to half way up the upper leg, thereby immobilizing the knee joint. The knee joint was casted in a 30 degrees angle, making weight bearing on the casted leg impossible. Subjects received instructions on the use of elbow crutches and were informed not to bear any weight on their casted limb. All subjects were instructed to perform a series of simple ankle exercise (i.e. plantar and dorsal flexion, and circular movements of the entire foot) to keep the calf muscle pump activated in the immobilized leg, thereby minimizing the risk of developing deep vein thrombosis.

\section{Diet and physical activity}

All subjects received the same standardized meal $\left(33 \pm 2 \mathrm{~kJ}^{\mathrm{kg}}{ }^{-1}\right.$ body weight, providing 44 energy\% (En\%) carbohydrate, 22 En\% protein, and 34 En\% fat) the evening prior to the muscle biopsy sampling. In addition, all volunteers were instructed to refrain from strenuous physical activity and to keep their diet as consistent as possible for 2 days prior to the muscle biopsy sampling. 


\section{Immunohistochemistry}

Frozen muscle biopsies were cut into $5 \mu \mathrm{m}$ thick cryosections using a cryostat at $-20^{\circ} \mathrm{C}$, and thaw mounted on uncoated pre-cleaned glass slides. Samples from pre and, post immobilization and 6 weeks of natural recovery were mounted together on the same glass slide. Care was taken to properly align the samples for cross-sectional muscle fiber analyses. Muscle biopsies were stained for muscle fiber typing (FT) and myocellular satellite cell content. First antibodies were directed against laminin (polyclonal rabbit anti-laminin, dilution 1:50; Sigma, Zwijndrecht, the Netherlands), myosin heavy chain (MHC)-I (A4.840, dilution 1:25; Developmental Studies Hybridoma Bank, lowa City, IA), and CD56 (dilution 1:40, BD Biosciences, San Jose, CA). CD56 has been extensively used in determination of satellite cell content in human skeletal muscle tissue $(20,33,37,46$, $48,50)$. Appropriate secondary antibodies were applied: goat anti-rabbit IgG Alexa647, goat anti-mouse IgM Alexa 555, and Streptavidin Alexa 488 (dilution 1:400, 1:500, and 1:200, respectively; Molecular Probes, Invitrogen, Breda, the Netherlands). Nuclei were stained with 4,6-diamidino-2-phenylindole (DAPI, $0.238 \mu \mathrm{M}$; Molecular Probes). All primary and secondary antibodies were diluted in $0.1 \%$ bovine serum albumin (BSA) in $0.1 \%$ Tween-phosphate-buffered saline (PBS). All incubations took place at room temperature, unless otherwise stated. Staining procedures were as follows. After fixation ( 5 min acetone), slides were air dried and incubated at room temperature for 30 min with $3 \%$ BSA in $0.1 \%$ Tween-PBS. Slides were then washed (5 min PBS), before they were incubated with CD56 in $0.1 \%$ BSA in $0.1 \%$ Tween-PBS for $2 \mathrm{~h}$. Afterwards slides were washed (standard washing protocol: 5 min 0.1\% Tween-PBS, $2 \times 5$ min PBS) and incubated with goat anti-mouse biotin (dilution 1:133, Vector Laboratories, Inc., Burlingame, CA) for $60 \mathrm{~min}$, to optimize the staining result. After washing, slides were incubated with streptavidin for $60 \mathrm{~min}$. After another washing step, primary antibodies against laminin and MHC-I were applied for $45 \mathrm{~min}$. Slides were then washed and incubated with the appropriate secondary antibodies, diluted together with DAPI. After a final washing step, all slides were mounted with cover glasses using Mowiol (Calbiochem, Amsterdam, the Netherlands). Staining procedures resulted in nuclei stained in blue, CD56 in green, MHC-I in red, and laminin in far-red (visualized in white/grey) (Figure 1). Images were visualized and automatically captured at 10x magnification with a fluorescent microscope equipped with an automatic stage (IX81 motorized inverted microscope, Olympus, Hamburg, Germany), a EXi Aqua CCD camera (QImaging). Micromanager 1.4 software was used for image acquisition (7). Quantitative analyses were done using ImageJ version $1.46 \mathrm{~d}$ software package (version $1.46 \mathrm{~d}$, National Institute of Health, MD (39)).All image recordings and analyses were performed by an investigator blinded to subject coding. Muscle fiber type (fiber\%), and fiber CSA were measured for each separate muscle fiber. As such, mean muscle fiber size was calculated for the type I and type II muscle fibers separately. As a measure of fiber circularity, form factors were calculated by using the following formula: $(4 \pi \cdot \operatorname{CSA}) /(\text { perimeter })^{2}$. No differences in fiber circularity were observed over time or between groups. The number of satellite 
cells per muscle fiber, the proportion of satellite cells [\#satellite cells/(\#satellite cells + \#myonuclei)*100], and the number of satellite cells per fiber area (in $\mathrm{mm}^{2}$ ) were calculated for the type I and type II muscle fibers separately. In addition, within each image the number of myonuclei and central myonuclei per muscle fiber and the mean fiber area per myonucleus (fiber CSA/\#myonuclei) were assessed for the type I and type II muscle fibers. Mean numbers of $569 \pm 81,520 \pm 67$, and $668 \pm 93$ muscle fibers were analyzed in the biopsy samples collected prior to and after 2 wks of immobilization and after 6 wks of natural recovery, respectively.
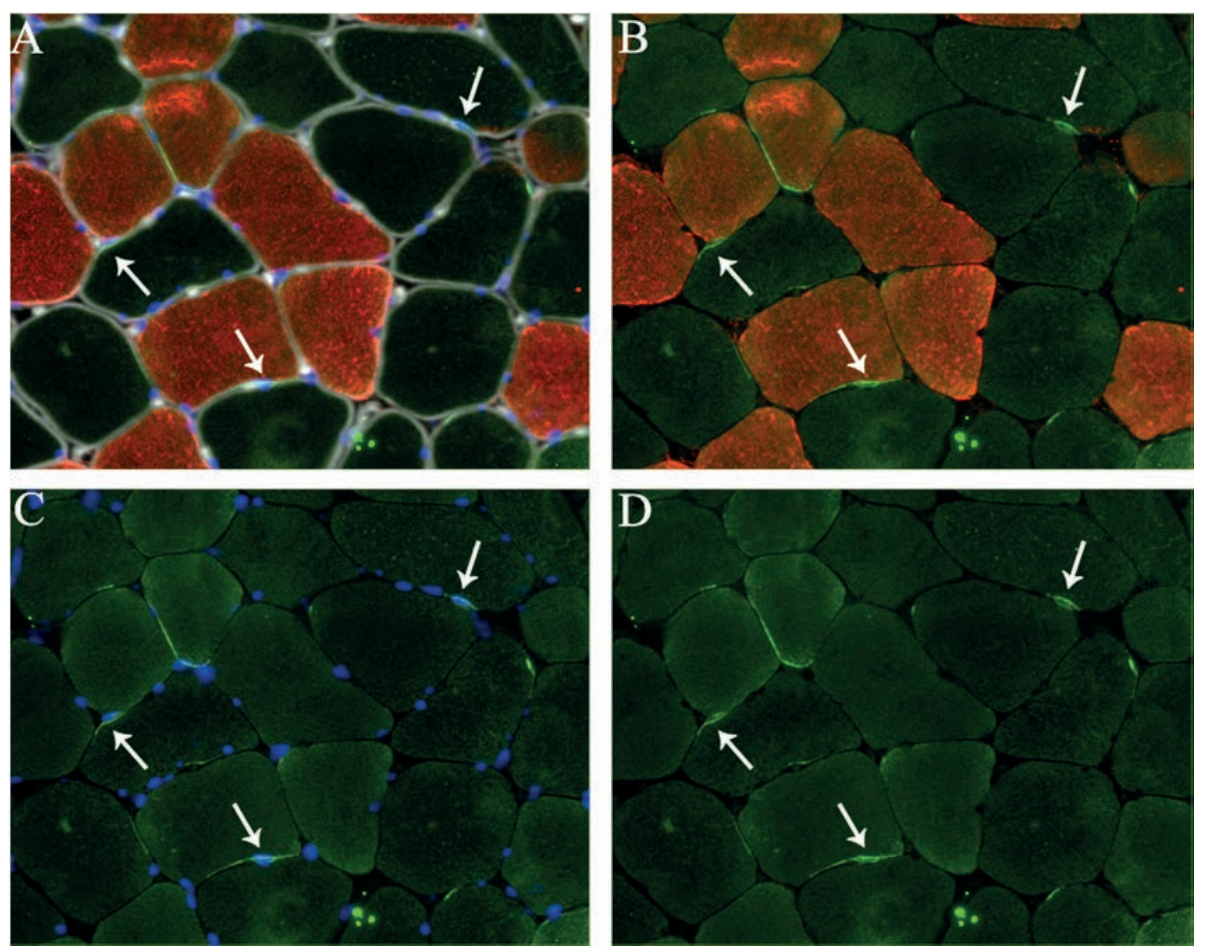

Figure 1 Representation of fiber type-specific analyses of satellite cell (SC) content. A: $\mathrm{MHCl}+$ laminin+Dapi+CD56. B: $\mathrm{MHCl}+\mathrm{CD} 56$. C: CD56+Dapi. D: CD56 only. Arrows indicate the location of the SCs

\section{rtPCR}

Total RNA was isolated from 10-20 mg of frozen muscle tissue using Tri Reagent (SigmaAldrich), according to the manufacturer's protocol. Total RNA quantification was carried out spectrophotometrically at $260 \mathrm{~nm}$ (NanoDrop ND-1000 Spectrophotometer, Thermo Fisher Scientific, USA), and RNA purity was determined as the ratio of readings at 260/280 nm. Thereafter, first strand cDNA was synthesized from $1 \mu \mathrm{g}$ RNA sample using random primers (Promega) and PowerScript Reverse Transcriptase (AppliedBiosystems, USA). Taqman PCR was carried out using an ABI Prism 7000 sequence detector (Ap- 
pliedBiosystems), with $2 \mu \mathrm{L}$ of cDNA, $18 \mu \mathrm{l} . \mathrm{L}-1$ of each primer, $5 \mu \mathrm{l} . \mathrm{L}-1$ probe, and Universal Taqman $2 \times$ PCR mastermix (Eurogentec) in a $25 \mu \mathrm{L}$ final volume. Each sample was run in duplicate, in duplex reactions. The housekeeping genes $18 \mathrm{~S}$ and $\beta 2$-subunit were used and the geometric mean was taken as an internal control as both of these genes were unaffected by immobilization (mean $\mathrm{Ct}$ values were unaffected over time; data not shown). Taqman primer/probe sets for myogenin, MyoD, and myostatin were obtained from Applied Biosystems (Foster City, USA). All genes of interest were labelled with the fluorescent reporter FAM. The thermal cycling conditions used were: $2 \mathrm{~min}$ at $50 \mathrm{oC}, 10 \mathrm{~min}$ at $950 \mathrm{C}$, followed by 40 cycles at $950 \mathrm{C}$ for $15 \mathrm{~s}$ and $60 \mathrm{oC}$ for $1 \mathrm{~min}$. Ct values of the target genes were normalized to $\mathrm{Ct}$ values of the internal control (i.e. geometric mean of $18 \mathrm{~S}$ and $\mathrm{B} 2$-subunit), and final results were calculated according to the $2^{-\Delta \Delta C t}$ method. The baseline muscle biopsy of the subject who showed the median response with respect to immobilization induced changes in muscle mass was used to normalize the data. Relative expression rates were subsequently calculated for all other samples.

\section{Western blotting}

Each muscle sample frozen for biochemical analyses was homogenized in 14 volumes Tris buffer (20 mM Tris-HCL, 5 mM EDTA, 10 mM Na-pyrosphospate, $100 \mathrm{mM} \mathrm{NaF,} 2$ $\mathrm{mM}$ Na3VO4, 1\% Nonidet P-40; pH 7.4) supplemented with the following protease and phosphatase inhibitors: Aprotinin $10 \mu \mathrm{g} / \mathrm{mL}$, leupeptin $10 \mu \mathrm{g} / \mathrm{mL}$, benzamidin $3 \mathrm{mM}$ and PMSF $1 \mathrm{mM}$. After homogenization, each muscle extract was centrifuged for $5 \mathrm{~min}$ at 10,000 $\mathrm{g}(4 \stackrel{\circ}{ } \mathrm{C})$ and sample buffer (final concentration: $60 \mathrm{mM}$ Tris, 5\% glycerol, 20 $\mathrm{mg} / \mathrm{mL}$ SDS, $0.1 \mathrm{mM}$ DTT, $20 \mu \mathrm{g} / \mathrm{mL}$ bromophenolblue) was added to the supernatant. The supernatant was extracted and boiled for $5 \mathrm{~min}$ at $100^{\circ} \mathrm{C}$ and put on ice after sample buffer was added to the sample. Immediately prior to analysis, the muscle extraction sample was warmed to $50{ }^{\circ} \mathrm{C}$ and centrifuged for $1 \mathrm{~min}$ at 3,000 $\mathrm{g}$ (RT).

Total amount of sample loaded on the gel was based on weight ( $1.0 \mathrm{mg}$ muscle per lane). Protein samples were run on a Criterion "any kDa' gel (Biorad Order No. 5671124 ) for $10 \mathrm{~min}$ at $50 \mathrm{~V}$ (constant voltage) and subsequently $\pm 90 \mathrm{~min}$ at $150 \mathrm{~V}$ (constant voltage) and transferred onto a Trans-blot Turbo $0.2 \mu \mathrm{m}$ nitrocellulose membrane (Biorad Order No. 170-4159) in $7 \mathrm{~min}$ at $2.5 \mathrm{~A}$ and $25 \mathrm{~V}$. Specific proteins were detected by overnight incubation at 4 으 on a shaker with specific antibodies in $50 \%$ PBS Odyssey blocking buffer (Li-Cor Biosciences Part No. 927-40000) after blocking for 60 min at RT in 50\% PBS Odyssey blocking buffer. The antibodies used in this study were antimyostatin (52 and $26 \mathrm{kDa}$; dilution 1:500; rabbit polyclonal IgG; Santa Cruz sc-6885-R) and anti $\alpha$-actin (42 kDa; dilution 1:160,000, mouse monoclonal IgM; Sigma A2172). Following incubation membranes were washed 3 times $10 \mathrm{~min}$ in $0.1 \%$ PBS-Tween 20 and once for $10 \mathrm{~min}$ in PBS. Next, samples were incubated ( $1 \mathrm{~h}$ at RT) with secondary antibodies, donkey anti-rabbit IRDYE 680 (Li-Cor, Cat. No. 926-32223, dilution 1:10,000) and donkey anti-mouse IRDYE 800CW (Li-Cor, Cat. No. 926-32212, dilution 1:10,000) 
dissolved in 50\% PBS Odyssey blocking buffer. After a final wash step ( $3 \times 5 \mathrm{~min}$ ) in $0.1 \%$ Tween 20-PBS and once $10 \mathrm{~min}$ in PBS, protein quantification was performed by scanning on an Odyssey Infrared Imaging System (LI-COR Biotechnology, Lincoln, NE).

\section{Statistics}

All data are expressed as means \pm SEM. Data were analyzed using a repeated measures ANOVA with leg (immobilized vs non-immobilized) and time (pre, post, and after 6wks of natural recovery) as within subject factors. For the muscle biopsy results, data were analyzed using a repeated measure ANOVA with time (pre, post, and after 6 weeks of natural recovery) and, when appropriate, fiber type (type I vs II) as within subject factors. Tukey post-hoc tests were performed in case of significant main effects of time. Separate analyses were performed in case of significant 'time $\mathrm{x}$ leg' or 'time $\mathrm{x}$ fiber type' interactions (i.e. only time as within subjects factor). Statistical significance was set at $\mathrm{P}<0.05$. All calculations were performed using SPSS 19.0 (Chicago, IL).

\section{Results}

\section{Muscle mass and strength}

Before the immobilization period no significant differences were observed in thigh or quadriceps muscle CSA between the two legs (Table 1). Following immobilization both thigh and quadriceps muscle CSA of the immobilized leg decreased significantly by $3 \pm 2$ and $8 \pm 2 \%$, respectively $(P<0.05)$, with no changes observed in the non-immobilized leg. In line, a significant decrease in leg lean mass of the immobilized of $\sim 350 \mathrm{~g}(3 \pm 1 \%)$ was observed following the $2 \mathrm{wk}$ immobilization period (Table $1 ; P<0.05$ ).

No significant changes in leg lean mass over time were observed in the control leg. Whole body and regional fat mass and/or fat percentage did not change significantly over time (data not shown).

In accordance with the decline in skeletal muscle mass in the immobilized leg, muscle strength was reduced following immobilization (Table 1). At baseline, no differences in muscle strength were observed between legs $(74 \pm 4$ and $74 \pm 4 \mathrm{~kg})$. In contrast, after immobilization, strength was significantly reduced by $23 \pm 3 \%$ in the immobilized leg (from $74 \pm 4$ to $56 \pm 4 \mathrm{~kg} ; P<0.05$ ) with no changes observed in the non-immobilized leg. Following 6 wks of natural rehabilitation thigh and quadriceps muscle CSA, leg lean mass and muscle strength had returned to baseline values in the (previously) immobilized leg. 
Table 1 Leg muscle strength, leg lean mass and leg muscle cross-sectional area

\begin{tabular}{|c|c|c|c|c|c|c|}
\hline & Before & $\begin{array}{c}\Delta \text { change } \\
\text { (after - } \\
\text { before) }\end{array}$ & $\begin{array}{c}\Delta \text { change } \\
\text { (6 wks - } \\
\text { before) }\end{array}$ & $\begin{array}{c}\text { Effect of } \\
\text { leg }\end{array}$ & $\begin{array}{l}\text { Effect of } \\
\text { time }\end{array}$ & $\begin{array}{l}\text { Leg } x \text { time } \\
\text { interaction }\end{array}$ \\
\hline Leg muscle strength (kg) & & & & $P<0.01$ & $P=0.02$ & $P<0.01^{*}$ \\
\hline Immob & $73.8 \pm 4.2$ & $-16.6 \pm 2.2$ & $0.2 \pm 1.5$ & & & \\
\hline Non-immob & $74.2 \pm 4.3$ & $2.0 \pm 1.7$ & $4.1 \pm 1.6$ & & & \\
\hline Leg lean mass (kg) & & & & $P=0.02$ & $P=0.05$ & $P<0.01^{*}$ \\
\hline Immob & $11.2 \pm 0.5$ & $-0.3 \pm 0.1$ & $-0.2 \pm 0.1$ & & & \\
\hline Non-immob & $11.1 \pm 0.5$ & $0.0 \pm 0.1$ & $0.1 \pm 0.1$ & & & \\
\hline Thigh muscle CSA $\left(\mathrm{cm}^{2}\right)$ & & & & $P<0.01$ & $P<0.01$ & $P<0.01 *$ \\
\hline Immob & $139.0 \pm 6.7$ & $-7.5 \pm 1.3$ & $0.0 \pm 1.2$ & & & \\
\hline Non-immob & $141.8 \pm 6.9$ & $0.0 \pm 1.0$ & $3.5 \pm 1.0$ & & & \\
\hline Quad CSA $\left(\mathrm{cm}^{2}\right)$ & & & & $P<0.01$ & $P<0.01$ & $P<0.01^{*}$ \\
\hline Immob & $76.7 \pm 3.8$ & $-6.4 \pm 1.5$ & $0.8 \pm 2$ & & & \\
\hline Non-immob & $77.1 \pm 3.7$ & $1.1 \pm 1.7$ & $2.8 \pm 1.6$ & & & \\
\hline
\end{tabular}

Values represent means \pm SEM; CSA: cross-sectional area. Immob: immobilized leg. Non-immob: nonimmobilized leg. Quad: Quadriceps muscle. * Significance values obtained from post-hoc analyses indicate that the effect of time is observed in the immobilized leg only, $P<0.01$.

\section{Muscle fiber type distribution and fiber size}

Muscle biopsies were collected from the immobilized leg only. At baseline, the proportion of type I and type II muscle fibers was $31 \pm 2 \%$ and $69 \pm 2 \%$, respectively. Though an overall significant effect over time was observed for the proportion of type II muscle fibers $(P=0.040)$, Tukey post-hoc analyses showed that the proportion of type II muscle fibers only tended to decrease from $69 \pm 3 \%$ to $58 \pm 4 \%$ following immobilization $(P=0.107)$, and then remained similar $(58 \pm 5 \%)$ after 6 weeks of natural rehabilitation. The proportion of muscle area occupied by type I and II fibers was $28 \pm 3 \%$ and $72 \pm 3 \%$, respectively, and did not change over time.

At baseline, there were no differences between type I and II muscle fiber size (7107 \pm 537 vs $7735 \pm 534 \mu \mathrm{m}^{2}$, respectively; Table 2 ). Immobilization led to a decrease in both type I and II muscle fiber size by $7 \pm 3(P<0.05)$ and $13 \pm 4 \%(P<0.05)$, respectively (Table 2). After six weeks of natural rehabilitation both type I and II muscle fiber size were no longer significantly different compared with baseline values (Table 2). 
Table 2 Muscle fiber size and myonuclear content

\begin{tabular}{|c|c|c|c|c|c|c|}
\hline & Before & $\begin{array}{c}\Delta \text { change } \\
\text { (after - } \\
\text { before) }\end{array}$ & $\begin{array}{c}\Delta \text { change } \\
\text { (6 wks - } \\
\text { before) }\end{array}$ & $\begin{array}{l}\text { Effect of } \\
\text { fiber } \\
\text { type }\end{array}$ & $\begin{array}{l}\text { Effect of } \\
\text { time }\end{array}$ & $\begin{array}{c}\text { Fiber type } x \\
\text { time interac- } \\
\text { tion }\end{array}$ \\
\hline Muscle fiber size $\left(\mu \mathrm{m}^{2}\right)$ & & & & $P=0.38$ & $P<0.01^{*}$ & $P=0.14$ \\
\hline Type I & $7107 \pm 537$ & $-569 \pm 287$ & $-744 \pm 372$ & & & \\
\hline Type II & $7735 \pm 534$ & $-1116 \pm 343$ & $-764 \pm 450$ & & & \\
\hline Myonuclei per fiber & & & & $P=0.31$ & $P=0.459$ & $P<0.05$ \\
\hline Type I & $4.4 \pm 0.3$ & $0.2 \pm 0.2$ & $0.0 \pm 0.2$ & & & \\
\hline Type II & $4.2 \pm 0.3$ & $-0.2 \pm 0.2$ & $-0.1 \pm 0.2$ & & & \\
\hline Myonuclear domain $\left(\mu \mathrm{m}^{2}\right)$ & & & & $P<0.01$ & $P=0.09$ & $P=0.58$ \\
\hline Type I & $1633 \pm 124$ & $-153 \pm 87$ & $-176 \pm 86$ & & & \\
\hline Type II & $1845 \pm 123$ & $-165 \pm 124$ & $-173 \pm 90$ & & & \\
\hline Central myonuclei per fiber & & & & $P=0.042$ & $P=0.93$ & $P=0.64$ \\
\hline Type I & $0.023 \pm 0.007$ & $0.003 \pm 0.009$ & $0.005 \pm 0.018$ & & & \\
\hline Type II & $0.042 \pm 0.010$ & $-0.021 \pm 0.012$ & $0.015 \pm 0.024$ & & & \\
\hline
\end{tabular}

Values represent means $\pm S E M$; * Significance values obtained from post-hoc analyses indicate the effect of time was only observed immediately after immobilization [ $\Delta$ change (After - before)], $P<0.01$.

\section{Myonuclear and satellite cell content}

Myonuclear and satellite cell content before and after immobilization, and after 6 weeks of natural recovery are displayed in Table 2 and 3, respectively. At baseline, the number of myonuclei per muscle fiber did not differ between type I and type II muscle fibers. In contrast, the myonuclear domain size was greater $(P<0.05)$ and the number of central myonuclei per muscle fiber was significantly higher $(P<0.05)$ in the type II compared with the type I muscle fibers (Table 2). Following immobilization a significant time $x$ fiber type interaction was observed for the number of myonuclei per muscle fiber $(P=0.012)$. However, post-hoc testing revealed no statistically significant differences between the 3 time points. In addition, no significant changes over time were observed in myonuclear domain size and/or the percentage of central myonuclei present. 
Table 3 Satellite cell content

\begin{tabular}{|c|c|c|c|c|c|c|}
\hline & Before & $\begin{array}{c}\Delta \text { change } \\
\text { (after - } \\
\text { before) }\end{array}$ & $\begin{array}{c}\Delta \text { change } \\
\text { (6 wks - } \\
\text { before) }\end{array}$ & $\begin{array}{l}\text { Effect of } \\
\text { fiber type }\end{array}$ & $\begin{array}{l}\text { Effect of } \\
\text { time }\end{array}$ & $\begin{array}{c}\text { Fiber type } x \\
\text { time interac- } \\
\text { tion }\end{array}$ \\
\hline SC per fiber & & & & $P=0.08$ & $P=0.16$ & $P=0.29$ \\
\hline Type I & $0.079 \pm 0.009$ & $0.018 \pm 0.008$ & $0.027 \pm 0.013$ & & & \\
\hline Type II & $0.069 \pm 0.009$ & $-0.003 \pm 0.011$ & $0.007 \pm 0.008$ & & & \\
\hline SC/myonuclei (\%) & & & & $P=0.08$ & $P=0.10$ & $P=0.31$ \\
\hline Type I & $1.78 \pm 0.17$ & $0.47 \pm 0.24$ & $0.65 \pm 0.32$ & & & \\
\hline Type II & $1.63 \pm 0.19$ & $0.05 \pm 0.28$ & $0.18 \pm 0.20$ & & & \\
\hline $\mathrm{SC} / \mathrm{mm}^{2}$ & & & & $P<0.01$ & $P<0.05^{*}$ & $P=0.32$ \\
\hline Type I & $11.2 \pm 1.1$ & $3.8 \pm 1.3$ & $5.7 \pm 1.7$ & & & \\
\hline Type II & $8.9 \pm 1.2$ & $0.8 \pm 1.5$ & $2.4 \pm 1.4$ & & & \\
\hline
\end{tabular}

Values represent means \pm SEM; * Significance values obtained from post-hoc analyses indicate the effect of time is only observed when the baseline was compared with the value after 6 weeks of natural rehabilitation [ $\Delta$ change (6 wks - before)], $P<0.01$.

At baseline, the number of satellite cells expressed per muscle fiber and as a proportion of total myonuclei did not differ between the type I and II muscle fibers. Furthermore, the number of satellite cells per muscle fiber did not change significantly over time in either the type I or type II muscle fibers (Table 3). In contrast, when satellite cell content was expressed per millimeter squared, a significantly greater number of satellite cells was observed in type I compared with type II muscle fibers at baseline. In addition, the number of satellite cells per millimeter squared in both muscle fiber types was significantly higher 6 weeks after immobilization when compared with baseline values (from $10.8 \pm 1.6$ and $8.7 \pm 0.8$ to $16.8 \pm 2.3$ and $9.5 \pm 1.2$ number of satellite cells per millimeter squared, in type I and type II muscle fibers, respectively; $P<0.05$ )

\section{Muscle mRNA expression}

Skeletal muscle mRNA expression is displayed in Figure 2. Following immobilization, the myogenin mRNA expression had increased 2.0 \pm 0.4 fold ( $P<0.05$; Figure $2 \mathrm{~B})$, after which levels returned to baseline following 6 weeks of natural rehabilitation. Though comparable changes over time were observed in MyoD and myostatin mRNA expression, these results did not reach statistical significance (Figure $2 \mathrm{~A}$ and $2 \mathrm{C}$ ). 

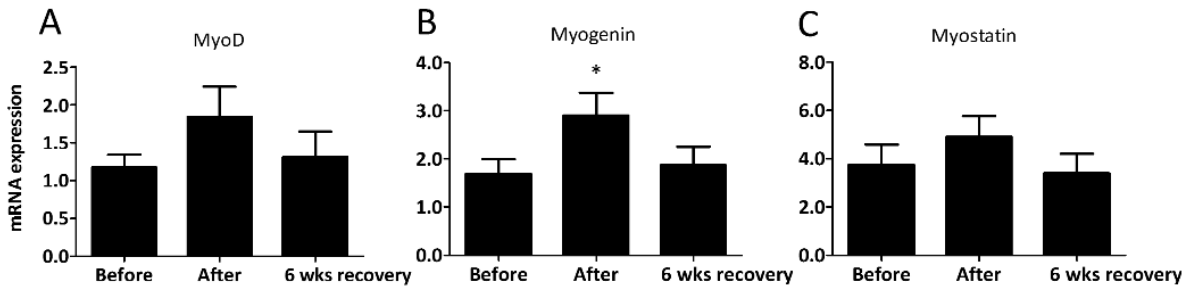

Figure 2 Mean $( \pm S E M)$ relative mRNA expression for MyoD $(A)$, myogenin $(B)$ and myostatin $(C)$ prior to, after 2 weeks of single leg knee immobilization, and following 6 weeks of subsequent natural rehabilitation. * Significantly different from before values $(P<0.05)$.
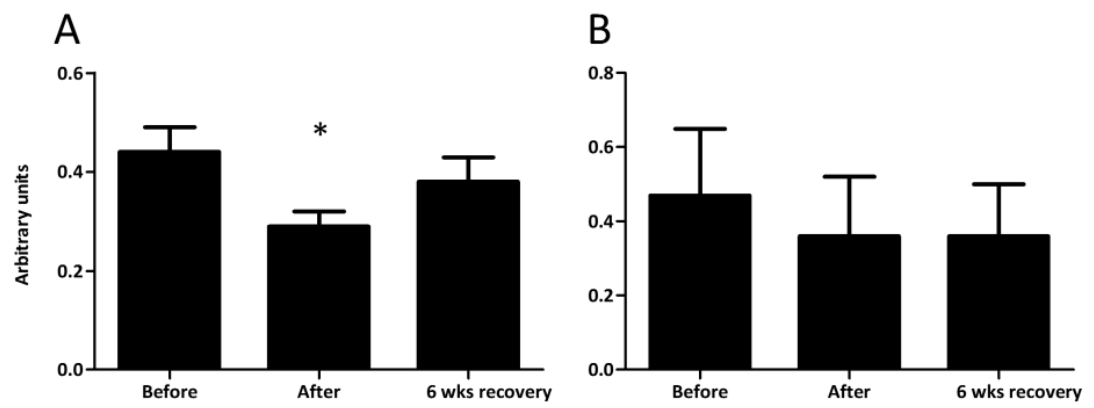

Figure 3 Mean ( \pm SEM) relative protein expression for Myostatin 52kDa (A) and 26kDa (B) prior to, after 2 wks of single leg knee immobilization and following 6 weeks of subsequent natural rehabilitation. Protein expression is expressed in arbitrary units per $\mathrm{mg}$ protein. ${ }^{*}$ significantly different from baseline values $(P<0.05)$.

\section{Muscle protein expression}

Skeletal muscle protein expression of the larger myostatin propeptide, detected at the $52 \mathrm{kDa}$ band, was significantly reduced $(30 \pm 9 \%)$ following immobilization $(P<0.05$; Figure $3 \mathrm{~A})$ before returning to baseline levels after 6 weeks of natural rehabilitation. No significant changes in muscle protein expression of the myostatin C-terminal (active) dimer, detected at $26 \mathrm{kDa}$, occurred over time (Figure 3B).

\section{Discussion}

The present study shows that two weeks of one-legged knee immobilization results in a considerable loss of skeletal muscle mass and strength. On a myocellular level, we observed a decrease in both type I and II muscle fiber cross sectional area (CSA) without parallel changes in muscle fiber type specific myonuclear or satellite cell content. Additionally, following 6 weeks of natural rehabilitation, muscle mass, strength and muscle 
fiber size had returned to baseline levels.

Skeletal muscle disuse following limb immobilization has repeatedly been shown to lead to extensive loss of skeletal muscle mass and strength in vivo in humans. In line, we report that 2 weeks of single leg immobilization leads to a $350 \mathrm{~g}$ loss of leg lean mass in healthy young men (Table 1 ). In accordance, we also observed a $9 \pm 2 \%$ decrease in quadriceps CSA with immobilization. Furthermore, this disuse atrophy was accompanied by a $22 \pm 3 \%$ decline in leg strength. On a muscle fiber level, previous studies have shown that in response to 3-21 days of limb immobilization muscle fiber size declines by $10-20 \%(16,24,45,55)$. Whereas some studies suggest that muscle disuse atrophy occurs predominantly in type I muscle fibers $(9,13,24)$, others have reported a reduction in both type I and type II muscle fiber size $(18,45,55)$. In the present study, we report that immobilization leads to both type I and type II muscle fiber atrophy (from $7107 \pm 537$ to $6326 \pm 359 \mu \mathrm{m}^{2}$ and from $7735 \pm 534$ to $6696 \pm 457 \mu \mathrm{m}^{2}$, respectively; Table 2).

Skeletal muscle satellite cells are known to play a significant role in skeletal muscle growth and regeneration and, as such, have been implicated as important regulators of muscle mass maintenance $(14,38)$. In previous studies using different models of muscle fiber atrophy, it has been demonstrated that a decline in muscle fiber size is often accompanied by a reduction in the number of skeletal muscle satellite cells $(26,47,48)$. It has been hypothesized that a decline in satellite cell content may precede the observed changes in muscle fiber size (38), and therefore be causative rather than simply a consequence. Thus, in the present study we assessed muscle fiber type dependent changes in the satellite cell pool size in response to 2 weeks of immobilization. In contrast to studies that applied models of prolonged muscle disuse $(46,48)$, the present study shows that type I and II muscle fiber atrophy following short-term muscle disuse is not accompanied by any measurable changes in satellite cell content (Table 3; effect of time $\mathrm{P}=0.162$ ). This infers that, in healthy young individuals a decline in satellite cell content is not a mechanistic prerequisite for subsequent muscle atrophy induced by short-term muscle disuse.

Aside from quantitative changes in satellite cell content, we also wanted to provide more insight into the molecular myogenic response to limb immobilization. We determined the changes in the mRNA expression of two important myogenic regulatory factors; MyoD and myogenin. The progression of satellite cells through the various stages of the myogenic program is known to be mediated by the expression of these factors and it has been suggested that the expression of MyoD is required to directly activate satellite cells through proliferation and differentiation (28). Further, under the action of myogenin satellite cells are committed to the process of terminal differentiation (54). Though no significant changes in MyoD gene expression were observed, we did observe a significant increase in myogenin mRNA expression in response to immobilization. This may indicate that after the 2 week immobilization period the satellite cell pool becomes more active. We speculate that an increase in myogenin expression fol- 
lowing immobilization may be representative of a counter-regulatory response aiming to attenuate muscle loss during short-term muscle disuse.

As a member of the transforming growth factor $\beta$ (TGF- $\beta$ ) family of proteins, myostatin is known to be a strong negative regulator of skeletal muscle mass in animals $(27,29)$ and humans (36). Mechanistically, myostatin has been suggested to regulate muscle mass by negatively influencing satellite cell differentiation via the myogenic regulatory factors, in particular MyoD and myogenin $(2,22,31,34)$ and/or via inhibition of muscle protein synthetic pathways $(1,35,44)$. While myostatin has been shown to be of key importance in the restoration of muscle mass following a period of disuse (19), its role in muscle disuse atrophy per se has not been assessed in humans. In the present study, we show a $30 \pm 9 \%$ decline in myostatin protein ( $52 \mathrm{kDa}$; larger myostatin propeptide) expression with a non-significant increase myostatin mRNA expression in response to immobilization (Figure $3 \mathrm{~A}$ and $2 \mathrm{C}$, respectively). The dis-connect between myostatin protein and mRNA expression is in line with previous work in the field $(8,21)$ and is attributed to a smad-7 dependent negative feedback loop through which increased myostatin protein expression is associated with decreased myostatin mRNA expression (8). We speculate that the observed reduction in whole muscle myostatin protein expression following immobilization is likely instrumental in the counter regulatory response to attenuate further muscle loss.

Despite the substantial loss of skeletal muscle mass following immobilization, we show that leg lean mass, Quadriceps muscle CSA and muscle strength returned to baseline values within six weeks of recovery without any specific rehabilitative program. In accordance, myostatin protein expression had increased back to pre-immobilization levels (Figure 3). Also, the repeated measures ANOVA does not reveal a significant difference in muscle fiber size between pre-immobilization and 6 weeks after natural rehabilitation (post-hoc analyses, $P=0.115$ ). However, numerically, muscle fiber size does not appear to have fully recovered 6 weeks after the immobilization period, especially in type I muscle fibers (Table 2). It could be suggested that muscle fiber size is still returning back to baseline, which would be in line with the non-significantly higher number of type I muscle fiber satellite cells after 6 weeks of natural rehabilitation. Overall though, it appears that in these healthy young subjects no specific intervention is necessary to regain the lost muscle mass and function following two weeks of one-legged knee immobilization. However, recent studies suggest that more clinically compromised elderly people have a reduced ability to regain skeletal muscle mass after a period of muscle disuse $(18,41)$. Future research should aim to provide insight into the cellular mechanisms responsible for a potentially attenuated muscle fiber growth after period of muscle disuse in more compromised populations.

In the present study, muscle disuse atrophy was induced by means of single leg cast immobilization. In contrast to ULLS and brace immobilization, a plaster cast will result in the most severe local physical inactivity. Consequently, the single leg cast immobilization model will yield the most robust reduction of muscle mass within a short time 
period. Hence, the results of the present study do not necessarily translate to other models of muscle disuse atrophy e.g. ULLS, brace immobilization and/or bed rest, as in these models (limited) weight bearing activities and/or joint movement can still be performed. In addition, caution should be taken in translating these results to more clinical conditions in which muscle fiber atrophy progresses over a much longer time period like in sarcopenia, cachexia and/or spinal cord injury.

We conclude that 2 weeks of muscle disuse leads to considerable loss of skeletal muscle mass and strength. The loss of muscle mass is attributed to both type I and type II muscle fiber atrophy, and is not accompanied by a decline in satellite cell content in either fiber type. These data provide compelling evidence that a decline in satellite cell content is not a mechanistic prerequisite for immobilization induced muscle atrophy. 


\section{References}

1. Amirouche A, Durieux AC, Banzet S, Koulmann N, Bonnefoy R, Mouret C, Bigard X, et al. Down-regulation of $\mathrm{Akt} / \mathrm{mammalian}$ target of rapamycin signaling pathway in response to myostatin overexpression in skeletal muscle. Endocrinology 150: 286-294, 2009.

2. Amthor H, Huang R, McKinnell I, Christ B, Kambadur R, Sharma M, and Patel K. The regulation and action of myostatin as a negative regulator of muscle development during avian embryogenesis. Dev Biol 251: 241-257, 2002.

3. Bergstrom J. Percutaneous needle biopsy of skeletal muscle in physiological and clinical research. Scand J Clin Lab Invest 35: 609-616, 1975.

4. Blakemore SJ, Rickhuss PK, Watt PW, Rennie MJ, and Hundal HS. Effects of limb immobilization on cytochrome c oxidase activity and GLUT4 and GLUT5 protein expression in human skeletal muscle. Clin Sci (Lond) 91: 591-599, 1996.

5. Deschenes M, Giles J, McCoy R, Volek J, Gomez A, and Kraemer W. Neural factors account for strength decrements observed after short-term muscle unloading. Am J Physiol Regul Integr Comp Physiol 282: 83, 2002.

6. Dudley G, Duvoisin M, Adams G, Meyer R, Belew A, and Buchanan P. Adaptations to unilateral lower limb suspension in humans. Aviation, space, and environmental medicine 63: 678-683, 1992.

7. Edelstein A, Amodaj N, Hoover K, Vale R, and Stuurman N. Computer control of microscopes using microManager. Curr Protoc Mol Biol Chapter 14: Unit14 20, 2010.

8. Forbes D, Jackman M, Bishop A, Thomas M, Kambadur R, and Sharma M. Myostatin auto-regulates its expression by feedback loop through Smad7 dependent mechanism. J of Cell Physiol 206: 264-272, 2006.

9. Gibson JN, Halliday D, Morrison WL, Stoward PJ, Hornsby GA, Watt PW, Murdoch G, et al. Decrease in human quadriceps muscle protein turnover consequent upon leg immobilization. Clin Sci (Lond) 72: $503-$ 509, 1987.

10. Glover E, Phillips S, Oates B, Tang J, Tarnopolsky M, Selby A, Smith K, et al. Immobilization induces anabolic resistance in human myofibrillar protein synthesis with low and high dose amino acid infusion. J Physiol 586: 6049-6061, 2008.

11. Glover El, Phillips SM, Oates BR, Tang JE, Tarnopolsky MA, Selby A, Smith K, et al. Immobilization induces anabolic resistance in human myofibrillar protein synthesis with low and high dose amino acid infusion. J Physiol 586: 6049-6061, 2008.

12. Hackney K, and Ploutz-Snyder L. Unilateral lower limb suspension: integrative physiological knowledge from the past 20 years (1991-2011). Eur J of Appl Physiol 112: 9-22, 2012.

13. Haggmark T, Jansson E, and Eriksson E. Fiber type area and metabolic potential of the thigh muscle in man after knee surgery and immobilization. Int J Sports Med 2: 12-17, 1981.

14. Hawke TJ, and Garry DJ. Myogenic satellite cells: physiology to molecular biology. J Appl Physiol 91: 534551, 2001.

15. Hespel P, Op't Eijnde B, Van Leemputte M, Urso B, Greenhaff PL, Labarque V, Dymarkowski S, et al. Oral creatine supplementation facilitates the rehabilitation of disuse atrophy and alters the expression of muscle myogenic factors in humans. J Physiol 536: 625-633, 2001.

16. Hortobagyi T, Dempsey L, Fraser D, Zheng D, Hamilton G, Lambert J, and Dohm L. Changes in muscle strength, muscle fibre size and myofibrillar gene expression after immobilization and retraining in humans. J Physiol 524 Pt 1: 293-304, 2000.

17. Hvid L, Aagaard P, Justesen L, Bayer M, Andersen J, Ørtenblad N, Kjaer M, et al. Effects of aging on muscle mechanical function and muscle fiber morphology during short-term immobilization and subsequent retraining. Journal of applied physiology (Bethesda, Md : 1985) 109: 1628-1634, 2010.

18. Hvid L, Aagaard P, Justesen L, Bayer ML, Andersen JL, Ortenblad N, Kjaer M, et al. Effects of aging on muscle mechanical function and muscle fiber morphology during short-term immobilization and subsequent retraining. In: J Appl Physiol2010, p. 1628-1634. 
19. Jones SW, Hill RJ, Krasney PA, O'Conner B, Peirce N, and Greenhaff PL. Disuse atrophy and exercise rehabilitation in humans profoundly affects the expression of genes associated with the regulation of skeletal muscle mass. FASEB J 18: 1025-1027, 2004.

20. Kadi F, Schjerling P, Andersen LL, Charifi N, Madsen JL, Christensen LR, and Andersen JL. The effects of heavy resistance training and detraining on satellite cells in human skeletal muscles. J Physiol 558: 10051012, 2004.

21. Kim J-s, Cross J, and Bamman M. Impact of resistance loading on myostatin expression and cell cycle regulation in young and older men and women. Am J Physiol Endocrinol Metab 288: 9, 2005.

22. Langley B, Thomas M, Bishop A, Sharma M, Gilmour S, and Kambadur R. Myostatin inhibits myoblast differentiation by down-regulating MyoD expression. J Biol Chem 277: 49831-49840, 2002.

23. Leenders M, Verdijk LB, van der Hoeven L, van Kranenburg J, Nilwik R, and van Loon LJ. Elderly Men and Women Benefit Equally From Prolonged Resistance-Type Exercise Training. J Gerontol A Biol Sci Med Sci 68:769-779, 2013.

24. Lindboe CF, and Platou CS. Effect of immobilization of short duration on the muscle fibre size. Clin Physiol 4: 183-188, 1984.

25. Mayhew JL, Prinster JL, Ware JS, Zimmer DL, Arabas JR, and Bemben MG. Muscular endurance repetitions to predict bench press strength in men of different training levels. J Sports Med Phys Fitness 35: 108-113, 1995.

26. McKay BR, Ogborn DI, Bellamy LM, Tarnopolsky MA, and Parise G. Myostatin is associated with agerelated human muscle stem cell dysfunction. FASEB J 26: 2509-2521, 2012.

27. McPherron AC, and Lee SJ. Double muscling in cattle due to mutations in the myostatin gene. Proc Natl Acad Sci USA 94: 12457-12461, 1997.

28. Megeney LA, Kablar B, Garrett K, Anderson JE, and Rudnicki MA. MyoD is required for myogenic stem cell function in adult skeletal muscle. Genes Dev 10: 1173-1183, 1996.

29. Mosher DS, Quignon P, Bustamante CD, Sutter NB, Mellersh CS, Parker HG, and Ostrander EA. A mutation in the myostatin gene increases muscle mass and enhances racing performance in heterozygote dogs. PLoS Genet 3: e79, 2007.

30. Moss FP, and Leblond CP. Satellite cells as the source of nuclei in muscles of growing rats. Anat Rec 170 : 421-435, 1971.

31. Muroya S, Watanabe K, Hayashi S, Miyake M, Konashi S, Sato Y, Takahashi M, et al. Muscle type-specific effect of myostatin deficiency on myogenic regulatory factor expression in adult double-muscled Japanese Shorthorn cattle. Anim Sci J 80: 678-685, 2009.

32. Nilwik R, Snijders T, Leenders M, Groen BB, van Kranenburg J, Verdijk LB, and van Loon LJ. The decline in skeletal muscle mass with aging is mainly attributed to a reduction in type II muscle fiber size. Exp Gerontol 48: 492-498, 2013.

33. Olsen S, Aagaard P, Kadi F, Tufekovic G, Verney J, Olesen JL, Suetta C, et al. Creatine supplementation augments the increase in satellite cell and myonuclei number in human skeletal muscle induced by strength training. J Physiol 573: 525-534, 2006.

34. Rios R, Carneiro I, Arce VM, and Devesa J. Myostatin is an inhibitor of myogenic differentiation. Am J Physiol Cell Physiol 282: C993-999, 2002.

35. Rodriguez J, Vernus B, Toubiana M, Jublanc E, Tintignac L, Leibovitch S, and Bonnieu A. Myostatin inactivation increases myotube size through regulation of translational initiation machinery. J Cell Biochem 112: 3531-3542, 2011.

36. Schuelke M, Wagner KR, Stolz LE, Hubner C, Riebel T, Komen W, Braun T, et al. Myostatin mutation associated with gross muscle hypertrophy in a child. N Engl J Med 350: 2682-2688, 2004.

37. Snijders T, Verdijk LB, Beelen M, McKay BR, Parise G, Kadi F, and van Loon L. A single bout of exercise activates skeletal muscle satellite cells during subsequent overnight recovery. Exp Physiol 97: 762-773, 2012.

38. Snijders T, Verdijk LB, and van Loon LJ. The impact of sarcopenia and exercise training on skeletal muscle satellite cells. Ageing Res Rev 8: 328-338, 2009. 
39. Strandberg S, Wretling ML, Wredmark T, and Shalabi A. Reliability of computed tomography measurements in assessment of thigh muscle cross-sectional area and attenuation. BMC Med Imaging 10: 18, 2010.

40. Suetta C, Frandsen U, Mackey A, Jensen L, Hvid L, Bayer M, Petersson S, et al. Ageing is associated with diminished muscle re-growth and myogenic precursor cell expansion early after immobility-induced atrophy in human skeletal muscle. J Physiol 591: 3789-3804, 2013.

41. Suetta C, Hvid LG, Justesen L, Christensen U, Neergaard K, Simonsen L, Ortenblad N, et al. Effects of aging on human skeletal muscle after immobilization and retraining. J Appl Physiol 107: 1172-1180, 2009.

42. Tesch PA, Trieschmann JT, and Ekberg A. Hypertrophy of chronically unloaded muscle subjected to resistance exercise. J Appl Physiol 96: 1451-1458, 2004.

43. Thom JM, Thompson MW, Ruell PA, Bryant GJ, Fonda JS, Harmer AR, De Jonge XA, et al. Effect of 10-day cast immobilization on sarcoplasmic reticulum calcium regulation in humans. Acta Physiol Scand 172: 141-147, 2001.

44. Trendelenburg AU, Meyer A, Rohner D, Boyle J, Hatakeyama S, and Glass DJ. Myostatin reduces Akt/TORC1/p70S6K signaling, inhibiting myoblast differentiation and myotube size. Am J Physiol Cell Physiol 296: C1258-1270, 2009.

45. Veldhuizen JW, Verstappen FT, Vroemen JP, Kuipers H, and Greep JM. Functional and morphological adaptations following four weeks of knee immobilization. Int J Sports Med 14: 283-287, 1993.

46. Verdijk LB, Dirks ML, Snijders T, Prompers JJ, Beelen M, Jonkers RA, Thijssen DH, et al. Reduced satellite cell numbers with spinal cord injury and aging in humans. Med Sci Sports Exerc 44: 2322-2330, 2012.

47. Verdijk LB, Gleeson BG, Jonkers RA, Meijer K, Savelberg HH, Dendale P, and van Loon LJ. Skeletal muscle hypertrophy following resistance training is accompanied by a fiber type-specific increase in satellite cell content in elderly men. J Gerontol A Biol Sci Med Sci 64: 332-339, 2009.

48. Verdijk LB, Koopman R, Schaart G, Meijer K, Savelberg HH, and van Loon L. Satellite cell content is specifically reduced in type II skeletal muscle fibers in the elderly. Am J Physiol Endocrinol Metab 292: E151-157, 2007.

49. Verdijk LB, Snijders T, Beelen M, Savelberg HH, Meijer K, Kuipers H, and Van Loon LJ. Characteristics of muscle fiber type are predictive of skeletal muscle mass and strength in elderly men. J Am Geriatr Soc 58: 2069-2075, 2010.

50. Verney J, Kadi F, Charifi N, Feasson L, Saafi MA, Castells J, Piehl-Aulin K, et al. Effects of combined lower body endurance and upper body resistance training on the satellite cell pool in elderly subjects. Muscle Nerve 38: 1147-1154, 2008.

51. Wall B, Snijders T, Senden J, Ottenbros C, Gijsen A, Verdijk L, and van Loon L. Disuse impairs the muscle protein synthetic response to protein ingestion in healthy men. J Clin Endocrinol Metab DOI: 10.1210/jc.2013-2098, 2013.

52. Wall B, and van Loon L. Nutritional strategies to attenuate muscle disuse atrophy. Nutrition reviews 71 : 195-208, 2013.

53. White $M$, Davies $C$, and Brooksby $P$. The effects of short-term voluntary immobilization on the contractile properties of the human triceps surae. Q J Exp Physiol 69: 685-691, 1984.

54. Yablonka-Reuveni Z, and Rivera AJ. Temporal expression of regulatory and structural muscle proteins during myogenesis of satellite cells on isolated adult rat fibers. Dev Biol 164: 588-603, 1994.

55. Yasuda N, Glover El, Phillips SM, Isfort RJ, and Tarnopolsky MA. Sex-based differences in skeletal muscle function and morphology with short-term limb immobilization. J Appl Physiol 99: 1085-1092, 2005. 



\title{
CHAPTER 4
}

\section{A single bout of exercise activates skeletal muscle satellite cells during subsequent overnight recovery}

\author{
Tim Snijders \\ Lex B. Verdijk \\ Milou Beelen \\ Bryon R. McKay \\ Gianni Parise \\ Fawzi Kadi \\ Luc J.C. van Loon
}




\section{ABStract}

Introduction: Skeletal muscle satellite cell content has been reported to increase following a single bout of exercise. Data on muscle fiber type-specific satellite cell (SC) content and/or SC activation status are presently lacking. The objective of this study was to determine the impact of a single bout of exercise on muscle fiber type-specific SC content and activation status following subsequent overnight recovery.

Methods: Eight healthy males (age: $20 \pm 1$ yrs) performed a single bout of combined endurance and resistance type exercise. Muscle biopsies were collected before and immediately after exercise, and following $9 \mathrm{~h}$ of post-exercise, overnight recovery. Muscle fiber type-specific SC and myonuclear content, and SC activation status were determined by immunohistochemical analyses. SC activation status was assessed by immunohistochemical staining for both DLK1 and Ki-67.

Results: Muscle fiber size and fiber area per nucleus were greater in type II compared with type I muscle fibers $(P<0.05)$. At baseline, no differences were observed in the percentage of SC staining positive for DLK1 and/or Ki67 between fiber types. No significant changes were observed in SC content following $9 \mathrm{~h}$ of post-exercise, overnight recovery. However, the percentage of DLK1 positive SC had increased significantly during overnight recovery, from $22 \pm 5$ to $41 \pm 5 \%$ and from $24 \pm 6$ to $51 \pm 9 \%$ in the type I and II muscle fibers, respectively. No changes were observed in the percentage of Ki-67 positive SC.

Conclusion: A single bout of exercise activates both type I and II skeletal muscle fiber SC within a single night of post-exercise recovery, preceding the subsequent increase in SC content. 


\section{INTRODUCTION}

Skeletal muscle fibers contain hundreds of myonuclei and according to the myonuclear domain theory every nucleus can only control the required gene expression over a finite amount of cytoplasm, referred to as the myonuclear domain $(2,7)$. Hence, changes in muscle fiber size should be accompanied by changes in myonuclear domain and/or changes in the number of myonuclei per fiber $(23,24)$. However, as myonuclei are post-mitotic they are unable to generate new myonuclei. Consequently, the ability for more extensive muscle fiber hypertrophy depends on a small pool of myogenic precursors, termed satellite cells (SC) (18). In adult muscle tissue, SC are typically quiescent but can become activated in response to various stimuli, such as exercise. After proliferation, SC either differentiate to form new myonuclei or return to quiescence, thereby replenishing the resident pool of SC through self-renewal $(12,18,53)$. In accordance, myonuclear and SC content have been shown to increase in response to more prolonged exercise training, with concomitant increases in muscle fiber size (19, $23,29,36-38,42,46,50)$.

The activation, proliferation, and differentiation processes of the SC represent important regulatory steps for the SC pool to expand, allowing muscle hypertrophy to occur during more prolonged resistance type exercise intervention. Several studies have demonstrated an increase in mixed muscle SC content following merely 1 to up to as much as 8 days after performing a single bout of exercise $(10,11,13,32,34,35)$. Some studies even reported an increase in SC content within $24 \mathrm{~h}$ after performing a bout of exercise $(13,32,35)$. Clearly, the activation process of the SC must take place well within $24 \mathrm{~h}$ of post-exercise recovery. So far, data on SC activation following exercise in human skeletal muscle tissue are scarce $(40,52)$. A few markers have been suggested to be indicative of SC activation status, including Delta-like 1 homolog (DLK1) $(11,15,29,51)$ and Ki-67 $(28,34)$. In mice skeletal muscle, DLK1 depletion has been shown to result in defective muscle development and a delayed regenerative response (51). From both cell culture and in vivo animal data using knockout and over-expression models, Waddell et al. (51) suggested that DLK1 might act to inhibit SC proliferation and self-renewal and promote SC differentiation. Studies in human skeletal muscle support the notion that DLK1 is crucial during muscle development (3). Furthermore, DLK1 has been shown to co-localize with SC in vivo in human skeletal muscle $(3,26,28)$. However, the precise role of DLK1 in adult myogenesis and the SC adaptive response following a single bout of exercise remains to be established.

The Ki-67 antigen is regarded a marker for proliferating cells and has been reported to be expressed during the mid-G1-phase, with increased expression during the $\mathrm{S}$ and $\mathrm{G} 2$ phase and peaking in the $M$ phase of the cell cycle (16). The number of Ki67 positive SC has been shown to increase $48 \mathrm{~h}$ after an anabolic stimulus in vivo in human skeletal muscle (28). In this study the authors speculate that the number of SC expressing Ki-67 may already increase within the first $12 \mathrm{~h}$ of post-exercise recovery (28). So far no stud- 
ies have assessed both DLK1 and Ki-67 during recovery from a single bout of exercise. Moreover, no studies have aimed to assess SC activation status in a muscle fiber typespecific manner, which has recently been reported to be of particular relevance $(45$, 46). Consequently, the present study determines the impact of a single bout of combined resistance and endurance type exercise on skeletal muscle SC content and activation status in a muscle fiber type-specific manner in vivo in humans.

Most studies assess the impact of a single bout of exercise in the morning following an overnight fast. However, in daily practice exercise is generally performed in the evening with post-exercise recovery during subsequent overnight sleep (4). We hypothesize that SC activation status and/or SC content will increase during overnight recovery following a single bout of exercise. Therefore, we measured muscle fiber type-specific SC content and SC activation status in muscle tissue collected before and immediately after exercise and following subsequent overnight recovery. This study provides more insight in the timeline and regulation of the SC as myogenic precursors that allow the skeletal muscle adaptive response to exercise to occur.

\section{Method}

\section{Subjects}

Eight healthy, male volunteers (age: $20 \pm 1 \mathrm{yrs}$; height $1.77 \pm 0.03 \mathrm{~m}$; weight: $65 \pm 2 \mathrm{~kg}$ ) participated in this study (see Table 1). All participants were recreationally active, which was defined as participating in sports activities less than 3 times per week, but not on a regular and/or competitive basis. Subjects were informed about the nature and risks of the experimental procedures before written consent was obtained. The study was approved by the Medical Ethical Committee of the Maastricht University Medical Centre+, The Netherlands, and complied with the guidelines set out in the Declaration of Helsinki. This study is part of a greater project on the impact of exercise on skeletal muscle adaptation.

\section{Screening}

All subjects participated in 2 screening sessions separated by at least 5 days. In the morning, after an overnight fast, body composition was determined by the hydrostatic weighing method. Body fat percentage was calculated using Siri's equation (44) and leg volume was measured by anthropometry (20). Thereafter, subjects were familiarized with the exercise equipment and exercise procedures. Proper lifting technique was demonstrated and practiced for each of the upper-body exercises (chest-press, shoulder press and lat pull-down) and the 2 lower limb exercises (leg press and leg extension). Thereafter, maximum strength for the 2 leg exercises was estimated using the multiple repetition testing procedure (30). In the 2nd screening session, subjects' one repetition maximum (1-RM) was determined for the 2 leg exercises (49). In addition, 
subjects performed an incremental exhaustive exercise test on an electronically braked cycle ergometer (Lode Excalibur, Groningen, The Netherlands) to measure maximal oxygen uptake (VO2max) and workload capacity (Wmax) (25).

Table 1 Subjects' characteristics

\begin{tabular}{lc}
\hline Age $(\mathrm{yr})$ & $20 \pm 1$ \\
Height $(\mathrm{m})$ & $1.77 \pm 0.03$ \\
Weight $(\mathrm{kg})$ & $65.3 \pm 1.5$ \\
BMI $\left(\mathrm{kg} / \mathrm{m}^{2}\right)$ & $20.9 \pm 0.6$ \\
Body fat\% (Siri) & $10.9 \pm 1.6$ \\
$1 \mathrm{RM}$ leg press $(\mathrm{kg})$ & $203 \pm 9$ \\
1RM leg extension $(\mathrm{kg})$ & $116 \pm 4$ \\
Wmax $(\mathrm{W})$ & $285 \pm 14$ \\
VO2max $\left(\mathrm{mL} \cdot \mathrm{min}^{-1}\right)$ & $3306 \pm 221$ \\
\hline
\end{tabular}

Values are means $\pm S E M ; n=8$. BMI, body mass index; $1 \mathrm{RM}$, subject's one repetition maximum; Wmax, maximal oxygen uptake; VO2max, and workload capacity.

\section{Diet and activity prior to and during the experiments}

All subjects received a standardized diet the evening prior to the experimental day (3.7 MJ, consisting of 62 Energy\% (En\%) carbohydrate, 16 En\% protein, and $22 \mathrm{En} \%$ fat) and during the entire experimental day $\left(0.17 \pm 0.01 \mathrm{MJ} \cdot \mathrm{kg} \mathrm{bw}^{-1} \cdot \mathrm{d}^{-1}\right.$, consisting of $61 \pm 0.6 \mathrm{En} \%$ carbohydrate, $13 \pm 0.2 \mathrm{En} \%$ protein and $26 \pm 0.7 \mathrm{En} \%$ fat). Subjects' energy requirements were calculated using the Harris and Benedict equations (17) with a physical activity index of 1.7 (39). The investigators provided the subjects with measured amounts of all food products and subjects ingested all meals and snacks at predetermined time intervals. All participants were instructed to refrain from any sort of exhaustive physical labor and to keep their diet as constant as possible 2 days prior to the experimental day.

\section{Exercise protocol}

After 10 min of warming-up on the cycle ergometer $(50 \% \mathrm{Wmax})$, subjects cycled 4 times 5 min at $65 \%$ Wmax, alternated by 4 times 2.5 min at $45 \%$ Wmax. After a 5 min resting period, participants started with the resistance type exercise protocol, consisting of an upper- and lower-body workout. The upper-body workout was performed with a workload set at $40 \%$ of the total body-weight in which subjects completed 5 sets of 10 repetitions on 3 upper-body machines (chest-press, shoulder press and lat pulldown). A resting period of 1 min between sets was allowed. This was followed by a lower-limb workout, which consisted of 9 sets of 10 repetitions on the leg press machine (Technogym BV, Rotterdam, The Netherlands) and 9 sets of 10 repetitions on the 
horizontal leg press machine (Technogym). On both machines, 3 sets were completed at $55 \%$ of $1-\mathrm{RM}, 3$ at $65 \% 1-\mathrm{RM}$ and 3 at 75\% 1-RM, with 2 min rest periods between sets. Finally, participants performed 2 sets of 30 abdominal crunches. All subjects were verbally encouraged during the exercise program to complete the entire protocol within $120 \mathrm{~min}$.

\section{Muscle biopsy}

Muscle biopsies were obtained from the middle region of the vastus lateralis muscle 15 $\mathrm{cm}$ above the patella and approximately $2 \mathrm{~cm}$ away from the fascia by means of the percutaneous needle biopsy technique described by Bergström et al. (5). Muscle biopsies were taken before and immediately after cessation of exercise, and following $9 \mathrm{~h}$ of post-exercise, overnight recovery. The pre- and post-exercise muscle biopsies were taken through the same incision, with the needle pointed in distal and proximal direction, respectively. The biopsy at $9 \mathrm{~h}$ of post-exercise, overnight recovery was taken from the contralateral leg. Muscle biopsies were carefully freed from any visible fat and blood. Thereafter $20 \mathrm{mg}$ tissue was rapidly frozen in liquid nitrogen cooled isopentane and embedded in Tissue-Tek (Sakura Finetek Europe BV, The Netherlands), with another $\sim 25 \mathrm{mg}$ directly frozen in liquid nitrogen. Muscle biopsies were stored at -80 oC for subsequent histochemical analysis to determine myocellular characteristics and qualitative real-time qRT-PCR analyses to assess the changes in mRNA expression of several myogenic regulators.

\section{Immunohistochemical analysis}

From all muscle biopsy samples, $5 \mu \mathrm{m}$ thick cross-sections were cut at $-20 \stackrel{\circ}{ } \mathrm{C}$ using a cryostat. Muscle samples collected before and immediately after exercise and after following post-exercise recovery from each individual subject were mounted together on uncoated glass slides, and air-dried for $30 \mathrm{~min}$ at room temperature before being stored at $-20^{\circ} \mathrm{C}$ for subsequent analyses. Serial cross-sections were stained for muscle fiber typing and muscle fiber SC content. First antibodies used were directed against MHC-I (A4.951, Developmental Studies Hybridoma Bank [DSHB], lowa City, IA; dilution 1:20), laminin (polyclonal rabbit anti-laminin; Sigma, Zwijndrecht, The Netherlands; dilution 1:50), DLK1 (monoclonal Anti-human Pref-1/DLK1/FA1 antibody; R\&D systems, Minneapolis, U.S.; dilution 1:50), Ki-67 (Monoclonal Ki-67; Biocare Medical, Concord, CA, U.S.; dilution 1:200 ), and CD56 (BD biosciences, San Jose, CA; dilution 1:40). CD56 has been extensively used in various studies for the identification of SC $(6,13,14,22$, $23,46,48,50)$. DLK1 has been suggested to mark activated SCs. In addition, DLK1 has been shown to be colocalized with CD56 in human skeletal muscle $(26,29)$. The Ki-67 protein has been suggested to be associated with cell proliferation (43). The latter has already been used in previous studies to identify proliferating SC $(28,33,34)$. Appropriate secondary antibodies were applied: goat anti-mouse IgG1 (Alexa488), goat antimouse IgG2b (Alexa555), goat anti-rabbit IgG (Alexa555), goat anti-rabbit IgG 
(Alexa350), and goat anti-rat IgG (Alexa350). Nuclei were stained with 4,6-diamidino-2phenylindole (DAPI; Molecular Probes; $0.238 \mu \mathrm{M}$ ). Staining procedures for muscle fiber typing have been described previously (46-48). In short, muscle cross-sections were airdried for $30 \mathrm{~min}$ at room temperature, before being fixated (5 min acetone). Again slides were air-dried and incubated at room temperature with primary antibodies directed against laminin and MHC-I (dilution 1:50 and 1:25, respectively) diluted in $0.05 \%$ Tween-PBS, for $60 \mathrm{~min}$. Slides were then washed ( $3 * 5 \mathrm{~min}$ PBS). Thereafter, slides were incubated for $30 \mathrm{~min}$ at room temperature with the appropriate secondary anti-body diluted together with DAPI $(0.283 \mu \mathrm{M})$ in $0.05 \%$ Tween-PBS. After a final wash, slides were mounted with cover glasses using Mowiol (Calbiochem, Amsterdam, The Netherlands). The latter resulted in laminin stained in red, nuclei in blue, and MHC-I green (Figure 1).

For the identification and co-localization of SC with DLK1 or Ki-67, muscle cross-sections were air-dried for $30 \mathrm{~min}$ at room temperature, before being fixated ( $5 \mathrm{~min}$ acetone). Again slides were air-dried and incubated at $4{ }^{\circ} \mathrm{C}$ with primary antibodies directed against CD56 (dilution 1:40) and DLK1 (dilution 1:50) or only CD56 diluted in $0.05 \%$ Tween-PBS for $24 \mathrm{~h}$. The next day slides were washed ( $3 * 5 \mathrm{~min}$ PBS). Subsequently, slides were incubated for $30 \mathrm{~min}$ with the appropriate secondary anti-body diluted in $0.05 \%$ Tween-PBS. Slides were then washed ( $3 * 5$ min PBS). Slides were incubated at room temperature with antibodies against laminin (dilution 1:25) or laminin with Ki-67 (dilution 1:200) diluted in 0.05\% Tween-PBS, for respectively 60 and $120 \mathrm{~min}$. Again, slides were washed $(3 * 5$ min PBS). Thereafter, slides were incubated for 30 min with appropriate secondary anti-body, diluted together with DAPI $(0.283 \mu \mathrm{M})$ in $0.05 \%$ Tween-PBS. After a final wash, slides were mounted with cover glasses using Mowiol. This staining procedure resulted in laminin stained in blue, nuclei in blue, CD56 in green and DLK1 or Ki-67 in red (Figure 1).

\section{Data analyses}

From the biopsy slides, all images were captured using fluorescence microscopy with a Nikon E800 fluorescence microscope (Nikon Instruments Europe) coupled to a Basler A113 C progressive scan color CCD camera with a Bayer color filter. Epifluorescence signal was recorded using a Texas Red excitation filter (540-580 nm) for laminin, DLK1 or Ki-67, a DAPI UV excitation filter (340-380 nm) for the nuclei and laminin, and a FITC excitation filter (465-495 $\mathrm{nm}$ ) for either MHC-I or CD56. Image processing and quantitative analyses were done using Lucia 4.81 software package, as described previously $(46,48)$. All image recordings and analyses were performed by an investigator blinded to subject coding and/or study design.

From the fiber type stained muscle cross-sections, images were captured at a $120 \mathrm{x}$ magnification. Laminin was used to determine cell borders, and all fibers within each image were identified as either type I or type II muscle fibers. Within each image, the 
number of fibers, the mean fiber cross-sectional area (csa), the number of myonuclei per fiber, and the mean fiber area per nucleus (fiber csa/\#myonuclei) were assessed for the type I and II muscle fibers. Fiber circularity was calculated as $(4 \pi \cdot c s a) /(\text { perimeter })^{2}$. No differences in fiber circularity were observed over time or between fiber types. All images from the fiber type analyses were printed and a poster of the entire muscle section was prepared to identify type I and type II muscle fibers on serial muscle crosssections (i.e. sections stained for SC analyses).
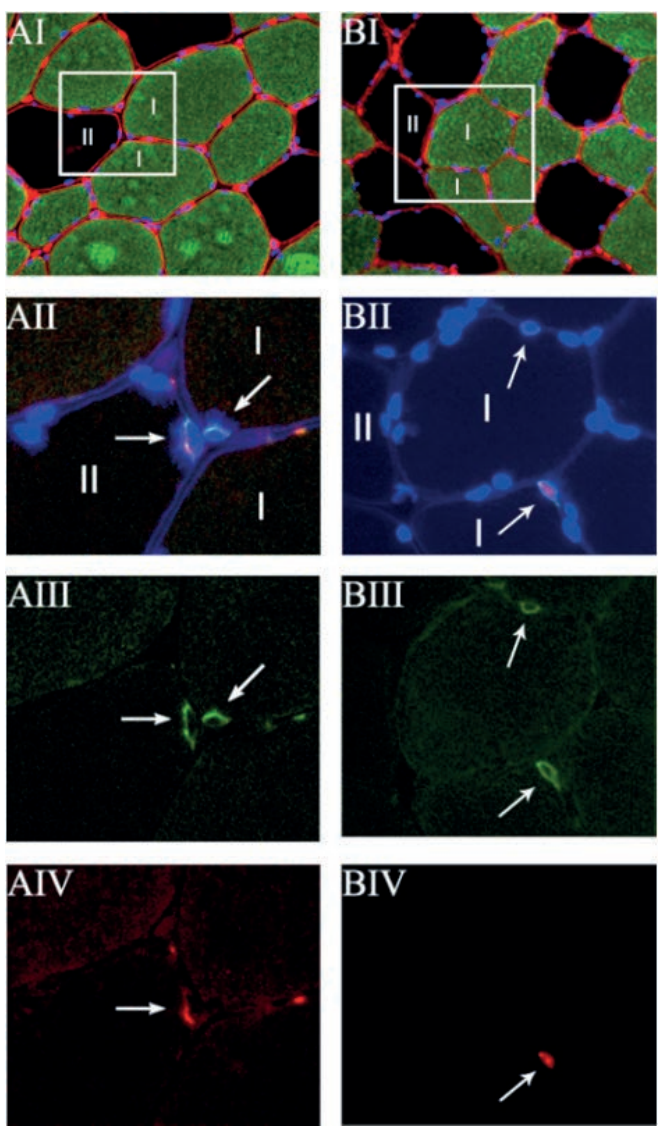

Figure 1 Representation of fiber type-specific analyses of skeletal muscle satellite cell content and activation status. (A/B-I) $\mathrm{MHC}$ I+Laminin+Dapi staining from serial section of $A / B-I I-A / B-I V$; the marked area represents the same area as presented in frames $A / B-I I-$ A/B-IV. (A-II) CD56+Dapi+laminin+DLK1. (B-II) CD56+Dapi+laminin+Ki67. (A/B-III). CD56 staining only. (A-IV) DLK1 staining only. (B-IV) Ki-67 staining only. Numbers indicate the type I and II muscle fibers. Arrows point at the satellite cell in quiescent, activated or proliferating state. 
From the SC stained muscle cross-sections, images were captured at a 240x magnification to allow clear SC localization. Laminin was used to visualize cell borders. Fiber typing was determined by matching the serial muscle fiber type slides. SC were determined at the periphery of each fiber and stained positive for both DNA (DAPI) and CD56. The number of SC per muscle fiber, the proportion of SC [\#SC/(\#SC + \#myonuclei)], and the number of SC per fiber area (in $\mathrm{mm}^{2}$ ) were calculated for the type I and II muscle fibers separately. To determine the activation status, co-localization of SC with DLK1 or Ki-67 was assessed in all muscle samples. Both markers were assessed on serial muscle sections with at least $30 \mu \mathrm{m}$ between the different sections to ascertain the uniqueness of the myonuclei/SC counted. The number of FA1+ or $\mathrm{Ki}-67+\mathrm{SC}$ per muscle fiber, the proportion of DLK1+ or Ki-67+ SC, and the number of FA1+ or Ki-67+ SC per fiber area (in $\mathrm{mm}^{2}$ ) were calculated for the type I and II muscle fibers separately. In addition, the proportion of SC staining positive for DLK1+ or Ki-67+ [\#SC staining positive for DLK1 or Ki67/ \#SC], were calculated for the type I and type II muscle fibers. A total of $721 \pm 48,689 \pm 28$ and $694 \pm 59$ muscle fibers were analyzed for each muscle biopsy sample collected before $(t=-2 h)$, immediately after $(t=0 h)$ exercise and following $9 \mathrm{~h}$ of overnight, post-exercise recovery.

\section{RNA isolation}

To provide more insight in the SC adaptive response following a single bout of exercise, gene expression analyses was performed for several key proteins implicated in SC activation, proliferation and/or differentiation. RNA was isolated from homogenized muscle samples using the TRIzol/RNeasy method. Briefly, approximately $25 \mathrm{mg}$ of each muscle sample was homogenized in a total of $1.0 \mathrm{~mL}$ TRIzol Reagent (Invitrogen Corporation, Canada) using a glass homogenizer ( $2 \mathrm{~mL}$ Kontes, Kimble Kontes, Germany). After the addition of chloroform, RNA was isolated as the liquid phase supernatant. 700 $\mu \mathrm{L}$ of the liquid phase was transferred into a Qiagen RNeasy mini spin column and RNA was purified by using the RNeasy mini kit (Cat. \# 74106), following the manufacturer's instructions (Qiagen Sciences, USA). The RNA was quantified using a spectrophotometer (NanoDrop 1000, Thermo Scientific, USA) and RNA integrity was assessed using a bioanalyzer (Agilent 2100, Agilent Technologies Canada Inc.). Average RIN values were $7.5 \pm 0.5$. 
Table 2 qRT-PCR Primer Sequences

\begin{tabular}{cccc}
\hline Gene Name & Forward Sequence & Reverse Sequence & $\begin{array}{c}\text { NCBI Gene } \\
\text { ID Number }\end{array}$ \\
\hline Myostatin & 5'-TGGTCATGATCTTGCTGTAAC-3' & 5'-TGTCTGTTACCTTGACCTCTA-3' & 2660 \\
Follistatin & 5'-AGTCCAGTACCAAGGCAGATG-3' & 5'-GGTCACACAGTAGGCATTATT-3' & 10468 \\
DLK1 & 5'-CTGCCTGCCTGGATGTGAT-3' & 5'-AGACAGCCTGGATAGCGGATA-3' & 28514 \\
MyoD & 5'-GGTCCCTCGCGCCCAAAAGAT-3' & 5'-CAGTTCTCCCGCCTCTCCTAC-3' & 4654 \\
Myf5 & 5'-ATGGACGTGATGGATGGCTG-3' & 5'-GCGGCACAAACTCGTCCCCAA-3' & 4617 \\
Myogenin & 5'-CAGTGCACTGGAGTTCAGCG-3' & 5'-TTCATCTGGGAAGGCCACAGA-3' & 4656 \\
MRF4 & 5'-CCCCTTCAGCTACAGACCCAA-3' & 5'-CCCCCTGGAATGATCGGAAAC-3' & 4618 \\
GAPDH & 5'-CCTCCTGCACCACCAACTGCTT-3' & 5'-GAGGGGCCATCCACAGTCTTCT-3' & 2597 \\
\hline
\end{tabular}

DLK1, Delta like-1; Myf5, myogenic factor 5; MRF4, muscle-specific regulatory factor 4 (Myf6); MyoD, myogenic determination factor; GAPDH, glyceraldehyde 3-phosphate dehydrogenase

\section{Reverse Transcription (RT)}

Individual samples were reverse transcribed in $20 \mu \mathrm{L}$ reactions using a commercially available kit (High Capacity cDNA Reverse Transcription Kit; Applied Biosystems, USA) according to the manufacturer's instructions. The cDNA synthesis reaction was carried out on an Eppendorf Mastercycle epgradient thermal cycler (Eppendorf, Canada).

\section{Quantitative Real-Time Polymerase Chain-Reaction (qRT-PCR)}

Individual $25 \mu \mathrm{L}$ reactions were prepared in $0.2 \mathrm{~mL}$ Eppendorf twin.tec PCR plates (Eppendorf, Canada) and run in duplicate for each time-point. Primers are listed in Table 2 and were re-suspended in $1 \mathrm{X}$ TE buffer (10 mM Tris- $\mathrm{HCl}, 0.11 \mathrm{mM}$ EDTA) and stored at $20^{\circ} \mathrm{C}$ prior to use. In each reaction tube, $1.0 \mu \mathrm{L}$ of CDNA and $7.5 \mu \mathrm{L}$ of ddH2O were added to $16.5 \mu \mathrm{L}$ of a master mix containing $12.5 \mu \mathrm{L}$ of RT2 Real-Time SYBR Green/Rox PCR master mix (SuperArray Bioscience Corp., USA) along with $2 \mu \mathrm{L}$ of the specific forward and reverse primers. qRT-PCR reactions were carried out using a Eppendorf Mastercycler ep realplex2 real-time PCR System (Eppendorf, Canada). mRNA expression was calculated using the delta $\mathrm{Ct}$ method $\left(2^{-\Delta c t}\right)$ and fold changes from baseline were calculated using the delta-delta $\mathrm{Ct}$ method (27). Gene expression was normalized to the housekeeping gene glyceraldehyde 3-phosphate dehydrogenase (GAPDH). GAPDH expression did not differ between time-points.

\section{Statistics}

All data are expressed as means \pm SEM. Data were analyzed using a two-way repeated measures ANOVA with time (before exercise, after exercise and following overnight recovery) and fiber type (type I vs II) as within subject factors. In case of a significant interaction, separate analyses were performed for time effects in the type I and II muscle fibers. Next, post-hoc tests were performed to locate significant differences; Bonferroni correction was applied to adjust for multiple testing. For analysis of the mRNA 
expression a one-way repeated measures ANOVA was performed with time as within subject factor, using the $2^{-\Delta C t}$ method (arbitrary units). Statistical significance was set at $P<0.05$. All calculations were performed using SPSS 15.0 (Chicago, IL).

\section{RESULTS}

\section{Muscle fiber type distribution and fiber area}

Muscle fiber type composition showed $57 \pm 5 \%$ type I and $43 \pm 5 \%$ type II muscle fibers. The proportion of muscle fiber area occupied by type I and type II muscle fibers was $55 \pm 6$ and $45 \pm 6 \%$, respectively. Muscle fiber area was significantly greater in type II compared with type I fibers $\left(6513 \pm 392\right.$ vs $5986 \pm 347 \mu^{2}$, respectively; $\left.P<0.05\right)$. No changes were observed in fiber type distribution and/or muscle fiber size after $9 \mathrm{~h}$ of post-exercise recovery (Table 2 ).

Table 3 Muscle fiber area and myonuclear content

\begin{tabular}{lcccc}
\hline & $\begin{array}{c}\text { Fiber } \\
\text { type }\end{array}$ & $\begin{array}{c}\text { Before } \\
\text { exercise }\end{array}$ & $\begin{array}{c}\text { After } \\
\text { exercise }\end{array}$ & $\begin{array}{c}\text { Overnight } \\
\text { recovery }\end{array}$ \\
\hline Muscle fiber CSA $\left(\mu \mathrm{m}^{2}\right)$ & I & $5943 \pm 401$ & $5797 \pm 322$ & $5421 \pm 239$ \\
Nuclei/fiber & II & $6580 \pm 442^{*}$ & $6235 \pm 515^{*}$ & $6295 \pm 444^{*}$ \\
Fiber area/nucleus $\left(\mu \mathrm{m}^{2}\right)$ & I & $4.0 \pm 0.5$ & $3.3 \pm 0.2$ & $3.2 \pm 0.2$ \\
& II & $3.8 \pm 0.4$ & $3.1 \pm 0.3$ & $3.2 \pm 0.2$ \\
& I & $1574 \pm 136$ & $1796 \pm 117$ & $1723 \pm 111$ \\
\hline
\end{tabular}

Data represent means \pm SEM. CSA: fiber cross-sectional area; *: significantly different compared with type I muscle fibers $(\mathrm{P}<0.05)$. No significant changes over time in either type I or type II muscle fibers.

\section{Myonuclear number and satellite cell number}

The number of myonuclei did not differ between type I and II muscle fibers (Table 3). Yet, fiber area per nucleus was significantly larger in type II compared with type I muscle fibers $\left(1835 \pm 182\right.$ vs $1574 \pm 136 \mu \mathrm{m}^{2}$, respectively; $\left.P<0.05\right)$. SC content was significantly higher in type I compared with type II muscle fibers $(0.08 \pm 0.01$ vs $0.07 \pm 0.01$, respectively; $P<0.05)$. In accordance, the number of SC per $\mathrm{mm}^{2}$ fiber area was significantly higher in type I compared with the type II muscle fibers $(13.7 \pm 1.4$ vs $10.2 \pm 1.0$, respectively; $P<0.05$; Table 4). However, no significant differences were observed in the number of SC relative to the number of nuclei between fiber types. The number of myonuclei and/or fiber area per nucleus did not change over time. Though no significant changes were found in SC number per muscle fiber and per $\mathrm{mm}^{2}$ fiber area over time, we did observe a significant increase in the number of SC when expressed relative to the number of nuclei in both type I and type II muscle fibers (Table 4). 
Table 4 Muscle fiber type-specific satellite cell content

\begin{tabular}{lcccc}
\hline & Fiber type & $\begin{array}{c}\text { Before } \\
\text { exercise }\end{array}$ & $\begin{array}{c}\text { After } \\
\text { exercise }\end{array}$ & $\begin{array}{c}\text { Overnight } \\
\text { recovery }\end{array}$ \\
\hline Number of SC/fibers & I & $0.08 \pm 0.01^{*}$ & $0.08 \pm 0.01^{*}$ & $0.10 \pm 0.01^{*}$ \\
Number of SC/mm ${ }^{2}$ & II & $0.07 \pm 0.01$ & $0.07 \pm 0.01$ & $0.08 \pm 0.01$ \\
Number of SC/myonuclei (\%) & I & $13.7 \pm 1.4^{*}$ & $14.4 \pm 1.7^{*}$ & $18.8 \pm 2.2^{*}$ \\
& II & $10.2 \pm 1.0$ & $11.8 \pm 1.5$ & $13.3 \pm 1.5$ \\
& I & $2.1 \pm 0.3$ & $2.6 \pm 0.3$ & $3.2 \pm 0.4^{* *}$ \\
\hline
\end{tabular}

Data represent means \pm SEM. SC: satellite cell; $\mathrm{SC} / \mathrm{mm}^{2}$ : the number of $\mathrm{SC}$ per millimeter squared; $\mathrm{SC} /$ myonuclei (\%): the number of SCs as a percentage of the total number of myonuclei (ie, number of myonuclei + number of SCs); I: type I muscle; II: type II muscle.*: Significantly different compared with type II muscle fibers $(P<0.05)$. ${ }^{* *}$ : Significantly different compared with pre-exercise $(P<0.05)$.
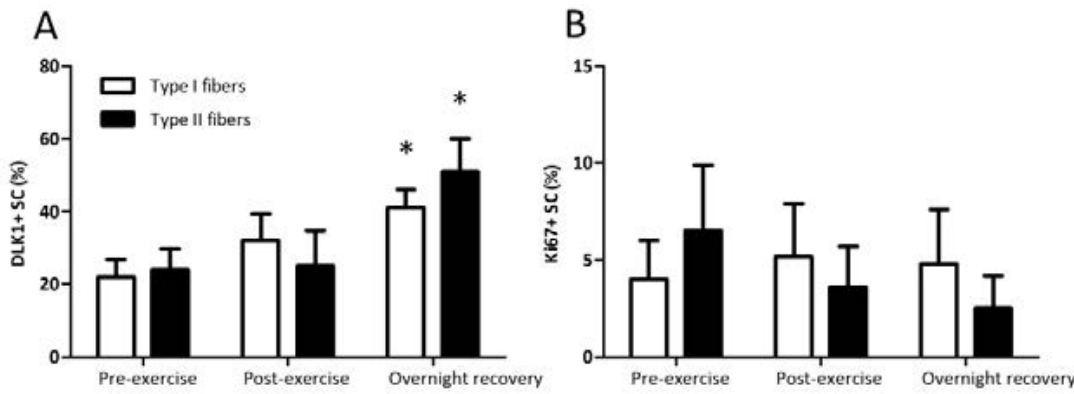

Figure 2 The percentage of satellite cells staining positive for Delta like homolog 1 (DLK1) (A) and Ki-67 (B) before and after a single exercise bout of exercise and following subsequent overnight recovery in type I and II muscle fibers. *: Significant time-effect. No significant differences were observed between type I and type II muscle fibers.

\section{Satellite cell activation status}

DLK1: Baseline DLK1 expression was observed in $22 \pm 5$ and $24 \pm 6 \%$ of the SC present in the type I and II muscle fibers, respectively (Figure 2A). The percentage of SC stained positive for DLK1 per muscle fiber did not differ between fiber types. Over time a significant increase was observed in the percentage of SC expressing DLK1 (from $22 \pm 5$ to $41 \pm 5 \%$ and from $24 \pm 6$ to $51 \pm 9 \%$ in the type I and II muscle fibers, respectively; Figure 2A). In accordance, the number of SC stained positive for DLK1 expressed per muscle fiber, per $\mathrm{mm}^{2}$ fiber area, or as a percentage of the total number of myonuclei all showed a significant increase over time (Table 5). Ki-67: In all muscle samples, the number of SC stained for Ki-67 were quite low. At baseline, only $4 \pm 2$ and $7 \pm 3 \%$ of the $\mathrm{SC}$ expressed $\mathrm{Ki}-67$ in the type I and II muscle fibers, respectively (Figure 2B). The percentage of SC expressing Ki-67 did not differ between fiber types. In addition, there 
were no significant changes in the percentage and/or number of SC expressing Ki-67 following exercise.

Table 5 Satellite cell activation status

\begin{tabular}{lcccc}
\hline & $\begin{array}{c}\text { Fiber } \\
\text { type }\end{array}$ & $\begin{array}{c}\text { Before exer- } \\
\text { cise }\end{array}$ & $\begin{array}{c}\text { After } \\
\text { exercise }\end{array}$ & $\begin{array}{c}\text { Overnight } \\
\text { recovery }\end{array}$ \\
\hline Number of SC DLK1+ cells/fiber & I & $0.02 \pm 0.01$ & $0.03 \pm 0.01$ & $0.04 \pm 0.01^{*}$ \\
Number of SC DLK1+ cells/mm & II & $0.01 \pm 0.01$ & $0.02 \pm 0.01$ & $0.04 \pm 0.01^{*}$ \\
Number of SC DLK1+ cells/myonuclei (\%) & I & $4.3 \pm 1.4$ & $4.1 \pm 1.2$ & $8.2 \pm 1.9^{*}$ \\
& II & $2.7 \pm 0.7$ & $2.3 \pm 0.9$ & $7.2 \pm 1.6^{*}$ \\
& I & $0.5 \pm 0.1$ & $0.9 \pm 0.3$ & $1.4 \pm 0.4^{*}$ \\
\hline
\end{tabular}

Data represent means \pm SEM. SC: Satellite cell. SC DLK1+ cells $/ \mathrm{mm}^{2}$ : the number of SC staining positive for DLK1 per millimeter squared; SC DLK1+ cells/myonuclei (\%): the number of SCs staining positive for DLK1 as a percentage of the total number of myonuclei (ie. Number of myonuclei + number of SCs); I: type I muscle; II: type II muscle.*: Significant time-effect $(P<0.05)$. No differences between muscle fiber types.
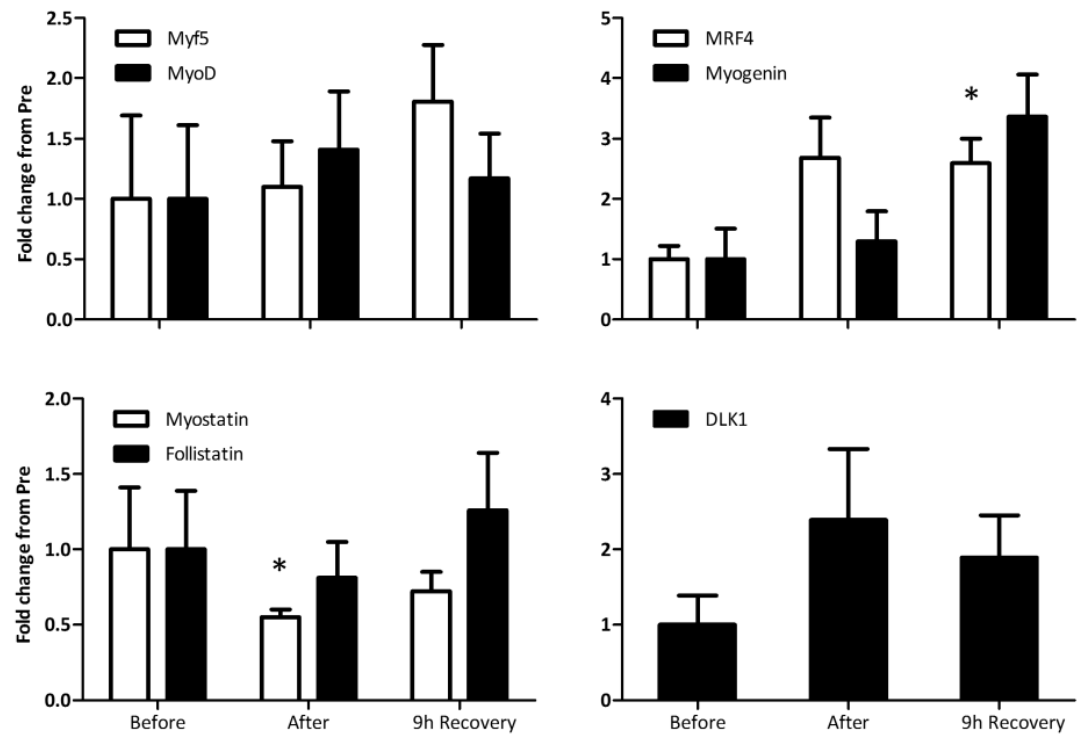

Figure 3 Changes in mRNA expression following a single bout of exercise and after subsequent overnight recovery. Fold changes were calculated using $2-{ }^{\Delta \Delta} \mathrm{Ct}$ method with genes of interest normalized to GAPDH. Values represent means \pm SEM. *: Significantly different compared with preexercise values. 


\section{mRNA expression}

Whereas MyoD mRNA expression did not change following the single bout of exercise, Myf5 mRNA expression tended $(P=0.088)$ to increase over time. Both MRF4 and myogenin $\mathrm{mRNA}$ expression showed a significant time-effect during post-exercise overnight recovery. MRF4 mRNA expression increased 2.6 fold $(P<0.05)$ during the $9 \mathrm{~h}$ recovery phase (Figure 3). Furthermore, post-hoc analyses of myogenin mRNA expression revealed a tendency for an overnight increase $(P=0.06$ versus pre-exercise and $P=0.08$ versus post-exercise values). Though no changes were observed in follistatin mRNA expression, a significant decrease in myostatin mRNA expression was observed immediately after exercise (Figure 3). DLK1 mRNA expression did not change over time (Figure 3).

\section{Discussion}

The present study shows that a single bout of combined resistance and endurance type exercise activates skeletal muscle SC in both type I and II muscle fibers during subsequent overnight recovery in healthy, young men. The latter precedes measurable increases in type I or II muscle fiber SC content.

SC activation, proliferation, and differentiation following an acute bout of exercise is generally believed to be essential to allow skeletal muscle hypertrophy following successive bouts of exercise in humans. The latter is supported by previous work in rodents that failed to show muscle hypertrophy in response to overloading in SC ablated muscle $(1,41)$. However, more recent work in mice (31) suggests that SC hold a more direct role in muscle fiber repair and/or generation of new muscle fibers and not muscle fiber hypertrophy per se. Whether the apparent discrepancy in the literature is attributed to differences between species remains a topic of debate. Despite this controversy, substantial increases in mixed muscle fiber SC content have been observed well within $24 \mathrm{~h}$ of recovery from a single bout of exercise in vivo in humans $(13,32$, $35)$. In the present study, we assessed muscle fiber type-specific SC content immediately after and following $9 \mathrm{~h}$ of post-exercise overnight recovery. A second muscle biopsy was collected immediately after exercise to assess a possible acute SC response to exercise. Even though we did not expect to detect any measurable increases in SC content within a $9 \mathrm{~h}$ timeframe, we already observed a tendency for SC number to increase $(P=0.10$ and 0.08 with $S C$ numbers expressed per muscle fiber or per muscle fiber area, respectively; Table 4). When SC number was expressed as a percentage of the total number of myonuclei, SC content was already significantly increased following the $9 \mathrm{~h}$ of post-exercise recovery. Although this finding may to some extent be attributed to a non-significant lower number of myonuclei at $9 \mathrm{~h}$ post exercise, we clearly observed an overall tendency for SC content to increase, which agrees with previous work reporting a significant increase in SC content $24 \mathrm{~h}$ after a single bout of eccentric exercise $(13,32$, 35). This tendency for an increase in SC content following overnight recovery implies 
that SC activation, and/or proliferation must occur well within $9 \mathrm{~h}$ of post-exercise recovery. Therefore, in the present study we aimed to assess SC activation status during these early stages of post-exercise recovery, i.e. immediately after and following $9 \mathrm{~h}$ of overnight recovery.

To identify the activation status of SC using immunohistological analyses of human skeletal muscle tissue, various markers have been suggested (21). As a member of the epidermal growth factor superfamily, DLK1 has been shown to play an important role in skeletal muscle development. Recent in vitro and animal studies suggest that DLK1 affects the SC fate choice between self-renewal and differentiation (51), with a peak expression observed at the stage of differentiation (3). However, human data are currently lacking. In resting human skeletal muscle, reports on SCs expressing DLK1 have been rather inconsistent. Whereas some studies report that DLK1 is expressed in up to $80 \%$ of the SCs (29), others show it is virtually absent in basal resting conditions (3). The latter would be in line with the suggestion that DLK1 expression peaks during the active stages of the cell cycle and is closely associated with differentiation (51). In the present study, $23 \%$ of the SC pool expressed DLK1 at baseline, with no difference between fiber types. It seems unlikely that in the resting condition such a large proportion of SC is activated, nor does this finding likely represent differentiating SC as (massive) differentiation would not be expected to occur within $9 \mathrm{~h}$ of post-exercise recovery. In a recent study by Lindstrom et al. (2010), it has been suggested that training status affects DLK1 expression in SCs during resting conditions. Subsequently, it could be speculated that in the present study habitual physical activity prior to the exercise bout might account for some degree of DLK1 expression in the baseline muscle biopsy samples. Besides resting conditions, little is also known about the change in DLK1 expression after a single bout of exercise in vivo in human skeletal muscle tissue. A single bout of eccentric exercise has been shown to increase the number of DLK1 mononuclear cells/myonuclei in healthy young men (11). However, no changes in the number of SC expressing DLK1 were observed in response to a 36-km run (29). Here, we show that the proportion of SC expressing DLK1 increased from $22 \pm 5 \%$ to $41 \pm 5 \%$ in type I and from $24 \pm 6 \%$ to $51 \pm 9 \%$ in type II muscle fibers, during post-exercise overnight recovery (Figure 2A). The progression of SC through the stage of proliferation and/or differentiation is known to be mediated by the expression of different myogenic regulatory factors (MyoD, Myf-5, Myogenin and MRF4) and negatively regulated by myostatin. In line with the greater DLK1 expression in the SC, the present study shows that $9 \mathrm{~h}$ following a single bout of exercise, both myogenin (3.4 fold) and MRF4 (2.6 fold) expression are upregulated. In addition, myostatin mRNA expression was reduced immediately following cessation of exercise (Figure 3). The changes in post-exercise mRNA expression of these key regulatory proteins are in line with previous reports $(40)$ and suggest that SC can change from a quiescent to a more active state within a few hours of post-exercise recovery. In accordance, we suggest that DLK1+ SC represent the progenitor cells that have been activated and, as such, are progressing through the cell cycle stages of pro- 
liferation, differentiation and/or self-renewal.

To further characterize SC activity in response to exercise, we assessed the presence of $\mathrm{Ki}-67$ in the SC in our tissue samples. Ki-67 is selectively expressed in cells during the active stages of the cell cycle (16) and has been applied successfully in previous studies to assess SC proliferation status in skeletal muscle tissue $(8,28,33,34)$. These studies have shown that during resting conditions the number of proliferating SC is quite low $(28,34)$. In agreement, we observed a percentage of merely $5 \pm 2 \%$ of proliferating (Ki$67+$ ) SC in mixed muscle tissue at baseline (Figure 2B). No significant differences in the percentage of proliferating SC was observed between muscle fiber types $(4 \pm 2 \%$ and $7 \pm 3 \%$ in the type I and II muscle fibers, respectively). So far, only few studies have looked at the number of proliferating SC using Ki-67 during recovery from a muscleloading stimulus (34). Data on the impact of exercise on SC proliferation during the early stages (0-24 h) of post-exercise recovery, preceding an increase in SC content, are entirely lacking. In this study, we observed no significant changes in the proportion of proliferating SC $9 \mathrm{~h}$ after cessation of exercise (Figure $2 \mathrm{~B}$ ). It could be suggested that SC are not yet proliferating within the first $9 \mathrm{~h}$ of post-exercise recovery. However, the latter is unlikely as the substantial rise in DLK1 positive cells and the observed tendency for SC content to increase should require an increased proliferative drive of the SC pool. The fact that we were unable to detect a measurable increase in Ki-67 positive SC could be attributed to numerous factors, which include a minimal amount of Ki-67 protein that is being expressed during proliferation, a high turnover rate of the protein, and/or simply a low affinity of the applied Ki-67 antibody. Overall, the present study is the first to show that the proportion of SC expressing DLK1 increases substantially in both type I and type II muscle fibers during $9 \mathrm{~h}$ of post-exercise overnight recovery, without an apparent increase in Ki-67 expression. Although the mechanism by which DLK1 controls the SC adaptive response following a single bout of exercise remains largely unknown, the mRNA expression provides further evidence that the number of active SCs is increased well within $9 \mathrm{~h}$ following a single bout of exercise. Further characterization of the DLK1 protein is required to reveal its significance in SC commitment during postexercise recovery.

In this study we assessed skeletal muscle fiber SC content as well as the activation status in a fiber type dependent manner. The latter has become more relevant since fiber type-specific changes in SC content have been observed in the elderly $(48,50)$. Moreover, SC content has been reported to increase in a fiber type-specific manner following subsequent resistance type exercise training $(46,50)$. In the present study we implemented both resistance and endurance type exercise to allow both type I and type II muscle fiber recruitment and, as such, to define potential differences in SC activation and subsequent proliferation during overnight recovery from a single bout of exercise. No difference in SC activation status was observed between the type I and II muscle fibers following overnight recovery from exercise (Figure 2). Clearly, muscle fiber recruitment leads to an early SC activation pattern that seems independent of fiber type. 
The early stages of post-exercise recovery set the stage for the subsequent increase in SC content, allowing skeletal muscle to remodel $(21,45)$. As such, the signaling processes leading to SC activation, proliferation, and differentiation are likely instrumental to the skeletal muscle adaptive response. Changes in the initial response and associated timeline of SC lineage determination may be responsible for the blunted skeletal muscle adaptive response to resistance type exercise training in the elderly $(9,13)$. Obtaining more insight in the initial stages of SC signaling in response to various anabolic stimuli may be of important clinical relevance to develop more effective exercise, nutrition, and/or pharmaceutical intervention strategies to increase muscle mass and function in both health and disease.

We conclude that a single bout of combined resistance and endurance type exercise activates both type I and II muscle fiber SC during subsequent overnight recovery. The latter occurs well before measurable increases in SC content. 


\section{ReferenCES}

1. Adams GR, Caiozzo VJ, Haddad F, and Baldwin KM. Cellular and molecular responses to increased skeletal muscle loading after irradiation. Am J Physiol Cell Physiol 283: C1182-1195, 2002.

2. Allen DL, Roy RR, and Edgerton VR. Myonuclear domains in muscle adaptation and disease. Muscle Nerve 22: 1350-1360, 1999.

3. Andersen DC, Petersson SJ, Jorgensen LH, Bollen P, Jensen PB, Teisner B, Schroeder HD, et al. Characterization of DLK1+ cells emerging during skeletal muscle remodeling in response to myositis, myopathies, and acute injury. Stem Cells 27: 898-908, 2009.

4. Beelen M, Koopman R, Gijsen AP, Vandereyt $H$, Kies AK, Kuipers $H$, Saris WH, et al. Protein coingestion stimulates muscle protein synthesis during resistance-type exercise. Am J Physiol Endocrinol Metab 295: E70-77, 2008.

5. Bergstrom J. Percutaneous needle biopsy of skeletal muscle in physiological and clinical research. Scand J Clin Lab Invest 35: 609-616, 1975.

6. Charifi N, Kadi F, Feasson L, and Denis C. Effects of endurance training on satellite cell frequency in skeletal muscle of old men. Muscle Nerve 28: 87-92, 2003.

7. Cheek DB. The control of cell mass and replication. The DNA unit--a personal 20-year study. Early human development 12: 211-239, 1985.

8. Christov C, Chretien F, Abou-Khalil R, Bassez G, Vallet G, Authier FJ, Bassaglia Y, et al. Muscle satellite cells and endothelial cells: close neighbors and privileged partners. Mol Biol Cell 18: 1397-1409, 2007.

9. Conboy IM, Conboy MJ, Smythe GM, and Rando TA. Notch-mediated restoration of regenerative potential to aged muscle. Science (New York, NY 302: 1575-1577, 2003.

10. Crameri RM, Aagaard P, Qvortrup K, Langberg H, Olesen J, and Kjaer M. Myofibre damage in human skeletal muscle: effects of electrical stimulation versus voluntary contraction. J Physiol 583: 365-380, 2007.

11. Crameri RM, Langberg $H$, Magnusson $P$, Jensen $\mathrm{CH}$, Schroder HD, Olesen JL, Suetta $C$, et al. Changes in satellite cells in human skeletal muscle after a single bout of high intensity exercise. J Physiol 558: 333 340, 2004.

12. Dhawan J, and Rando TA. Stem cells in postnatal myogenesis: molecular mechanisms of satellite cell quiescence, activation and replenishment. Trends Cell Biol 15: 666-673, 2005.

13. Dreyer HC, Blanco CE, Sattler FR, Schroeder ET, and Wiswell RA. Satellite cell numbers in young and older men 24 hours after eccentric exercise. Muscle Nerve 33: 242-253, 2006.

14. Edgerton VR, and Roy RR. Regulation of skeletal muscle fiber size, shape and function. J Biomech 24 Suppl 1: 123-133, 1991.

15. Floridon C, Jensen CH, Thorsen P, Nielsen O, Sunde L, Westergaard JG, Thomsen SG, et al. Does fetal antigen 1 (FA1) identify cells with regenerative, endocrine and neuroendocrine potentials? A study of FA1 in embryonic, fetal, and placental tissue and in maternal circulation. Differentiation 66: 49-59, 2000.

16. Gerdes J, Lemke $H$, Baisch $H$, Wacker $H H$, Schwab $U$, and Stein $H$. Cell cycle analysis of a cell proliferation-associated human nuclear antigen defined by the monoclonal antibody Ki-67. J Immunol 133: 1710-1715, 1984.

17. Harris JA, and Benedict FG. A Biometric Study of Human Basal Metabolism. Proc Natl Acad Sci U S A 4: 370-373, 1918.

18. Hawke TJ, and Garry DJ. Myogenic satellite cells: physiology to molecular biology. J Appl Physiol 91: $534-$ 551, 2001.

19. Hikida RS, Staron RS, Hagerman FC, Walsh S, Kaiser E, Shell S, and Hervey S. Effects of high-intensity resistance training on untrained older men. II. Muscle fiber characteristics and nucleo-cytoplasmic relationships. J Gerontol A Biol Sci Med Sci 55: B347-354, 2000.

20. Jones PR, and Pearson J. Anthropometric determination of leg fat and muscle plus bone volumes in young male and female adults. J Physiol 204: 63P-66P, 1969.

21. Kadi F, Charifi N, Denis C, Lexell J, Andersen JL, Schjerling P, Olsen S, et al. The behaviour of satellite cells in response to exercise: what have we learned from human studies? Pflugers Arch 451: 319-327, 2005. 
22. Kadi F, Charifi N, and Henriksson J. The number of satellite cells in slow and fast fibres from human vastus lateralis muscle. Histochem Cell Biol 126: 83-87, 2006.

23. Kadi F, Schjerling P, Andersen LL, Charifi N, Madsen JL, Christensen LR, and Andersen JL. The effects of heavy resistance training and detraining on satellite cells in human skeletal muscles. J Physiol 558: 10051012, 2004.

24. Kadi F, and Thornell LE. Concomitant increases in myonuclear and satellite cell content in female trapezius muscle following strength training. Histochem Cell Biol 113: 99-103, 2000.

25. Kuipers H, Verstappen FT, Keizer HA, Geurten P, and van Kranenburg G. Variability of aerobic performance in the laboratory and its physiologic correlates. Int J Sports Med 6: 197-201, 1985.

26. Lindstrom M, Pedrosa-Domellof $F$, and Thornell LE. Satellite cell heterogeneity with respect to expression of MyoD, myogenin, Dlk1 and c-Met in human skeletal muscle: application to a cohort of power lifters and sedentary men. Histochem Cell Biol 134: 371-385, 2010.

27. Livak KJ, and Schmittgen TD. Analysis of relative gene expression data using real-time quantitative PCR and the 2(-Delta Delta C(T)) Method. Methods 25: 402-408, 2001.

28. Mackey AL, Kjaer M, Charifi N, Henriksson J, Bojsen-Moller J, Holm L, and Kadi F. Assessment of satellite cell number and activity status in human skeletal muscle biopsies. Muscle Nerve 40: 455-465, 2009.

29. Mackey AL, Kjaer M, Dandanell S, Mikkelsen KH, Holm L, Dossing S, Kadi F, et al. The influence of antiinflammatory medication on exercise-induced myogenic precursor cell responses in humans. J Appl Physiol 103: 425-431, 2007.

30. Mayhew JL, Prinster JL, Ware JS, Zimmer DL, Arabas JR, and Bemben MG. Muscular endurance repetitions to predict bench press strength in men of different training levels. J Sports Med Phys Fitness 35: 108-113, 1995.

31. McCarthy JJ, Mula J, Miyazaki M, Erfani R, Garrison K, Farooqui AB, Srikuea R, et al. Effective fiber hypertrophy in satellite cell-depleted skeletal muscle. Development 138: 3657-3666, 2011.

32. McKay BR, De Lisio M, Johnston AP, O'Reilly CE, Phillips SM, Tarnopolsky MA, and Parise G. Association of interleukin-6 signalling with the muscle stem cell response following muscle-lengthening contractions in humans. PLoS One 4: e6027, 2009.

33. McLoon LK, and Wirtschafter J. Activated satellite cells in extraocular muscles of normal adult monkeys and humans. Invest Ophthalmol Vis Sci 44: 1927-1932, 2003.

34. Mikkelsen UR, Langberg H, Helmark IC, Skovgaard D, Andersen LL, Kjaer M, and Mackey AL. Region specific prostaglandin blockade inhibits satellite cell proliferation in human skeletal muscle following eccentric exercise. J Appl Physiol 2009.

35. O'Reilly C, McKay B, Phillips S, Tarnopolsky M, and Parise G. Hepatocyte growth factor (HGF) and the satellite cell response following muscle lengthening contractions in humans. Muscle Nerve 38: 14341442, 2008.

36. Olsen S, Aagaard P, Kadi F, Tufekovic G, Verney J, Olesen JL, Suetta C, et al. Creatine supplementation augments the increase in satellite cell and myonuclei number in human skeletal muscle induced by strength training. J Physiol 573: 525-534, 2006.

37. Petrella JK, Kim JS, Cross JM, Kosek DJ, and Bamman MM. Efficacy of myonuclear addition may explain differential myofiber growth among resistance-trained young and older men and women. Am J Physiol Endocrinol Metab 291: E937-946, 2006.

38. Petrella JK, Kim JS, Mayhew DL, Cross JM, and Bamman MM. Potent myofiber hypertrophy during resistance training in humans is associated with satellite cell-mediated myonuclear addition: a cluster analysis. J Appl Physiol 104: 1736-1742, 2008.

39. Plasqui G, and Westerterp KR. Seasonal variation in total energy expenditure and physical activity in Dutch young adults. Obes Res 12: 688-694, 2004.

40. Psilander N, Damsgaard R, and Pilegaard H. Resistance exercise alters MRF and IGF-I mRNA content in human skeletal muscle. J Appl Physiol 95: 1038-1044, 2003.

41. Rosenblatt JD, Yong D, and Parry DJ. Satellite cell activity is required for hypertrophy of overloaded adult rat muscle. Muscle Nerve 17: 608-613, 1994. 
42. Roth SM, Martel GF, Ivey FM, Lemmer JT, Tracy BL, Metter EJ, Hurley BF, et al. Skeletal muscle satellite cell characteristics in young and older men and women after heavy resistance strength training. J Gerontol A Biol Sci Med Sci 56: B240-247, 2001.

43. Scholzen T, and Gerdes J. The Ki-67 protein: from the known and the unknown. J Cell Physiol 182: 311322, 2000.

44. Siri WE. The gross composition of the body. Adv Biol Med Phys 4: 239-280, 1956.

45. Snijders T, Verdijk LB, and van Loon LJ. The impact of sarcopenia and exercise training on skeletal muscle satellite cells. Ageing Res Rev 8: 328-338, 2009.

46. Verdijk LB, Gleeson BG, Jonkers RA, Meijer K, Savelberg HH, Dendale P, and van Loon LJ. Skeletal muscle hypertrophy following resistance training is accompanied by a fiber type-specific increase in satellite cell content in elderly men. J Gerontol A Biol Sci Med Sci 64: 332-339, 2009.

47. Verdijk LB, Jonkers RA, Gleeson BG, Beelen M, Meijer K, Savelberg HH, Wodzig WK, et al. Protein supplementation before and after exercise does not further augment skeletal muscle hypertrophy after resistance training in elderly men. Am J Clin Nutr 89: 608-616, 2009.

48. Verdijk LB, Koopman R, Schaart G, Meijer K, Savelberg HH, and van Loon L. Satellite cell content is specifically reduced in type II skeletal muscle fibers in the elderly. Am J Physiol Endocrinol Metab 292: E151-157, 2007.

49. Verdijk LB, van Loon L, Meijer K, and Savelberg HH. One-repetition maximum strength test represents a valid means to assess leg strength in vivo in humans. J Sports Sci 27: 59-68, 2009.

50. Verney J, Kadi F, Charifi N, Feasson L, Saafi MA, Castells J, Piehl-Aulin K, et al. Effects of combined lower body endurance and upper body resistance training on the satellite cell pool in elderly subjects. Muscle Nerve 38: 1147-1154, 2008.

51. Waddell JN, Zhang P, Wen Y, Gupta SK, Yevtodiyenko A, Schmidt JV, Bidwell CA, et al. Dlk1 is necessary for proper skeletal muscle development and regeneration. PLoS One 5: e15055, 2010.

52. Yang $Y$, Creer A, Jemiolo B, and Trappe S. Time course of myogenic and metabolic gene expression in response to acute exercise in human skeletal muscle. J Appl Physiol 98: 1745-1752, 2005.

53. Zammit PS, Golding JP, Nagata Y, Hudon V, Partridge TA, and Beauchamp JR. Muscle satellite cells adopt divergent fates: a mechanism for self-renewal? J Cell Biol 166: 347-357, 2004. 


\title{
CHAPTER 5
}

\section{Eccentric exercise increases satellite cell content in type II muscle fibers}

\author{
Naomi M. Cermak \\ Tim Snijders \\ Bryon R. McKay \\ Gianni Parise \\ Lex B. Verdijk \\ Mark A. Tarnopolsky \\ Martin J. Gibala \\ Luc J.C. van Loon
}




\section{ABStract}

Introduction: Satellite cells (SCs) are of key importance in skeletal muscle tissue growth, repair and regeneration. A single bout of high-force eccentric exercise has been demonstrated to increase mixed muscle satellite cell (SC) content following 1-7 d of post-exercise recovery. However, little is known about fiber type specific changes in SC content and their activation status within $24 \mathrm{~h}$ of post-exercise recovery.

Methods: Nine recreationally active young men ( $23 \pm 1$ y) performed 300 eccentric actions of the knee extensors on an isokinetic dynamometer. Skeletal muscle biopsies from the vastus lateralis were collected pre- and $24 \mathrm{~h}$ post-exercise. Muscle fiber type specific SC content and the number of activated SCs were determined by immunohistochemical analyses.

Results: There was no difference between type I and II muscle fiber SC content prior to exercise. SC content significantly increased $24 \mathrm{~h}$ post-exercise in type II muscle fibers (from $0.085 \pm 0.012$ to $0.133 \pm 0.016$ SCs per fiber, respectively; $P<0.05$ ) whereas there was no change in type I fibers. In accordance, activation status increased from pre- to $24 \mathrm{~h}$ post-exercise as demonstrated by the increase in the number of DLK1+ SCs in type II muscle fibers (from $0.027 \pm 0.008$ to $0.070 \pm 0.017$ SCs per muscle fiber $P<0.05$ ). Although no significant changes were observed in the number of Ki-67+ SCs, we did observe an increase in the number of PCNA+ SCs after $24 \mathrm{~h}$ of post-exercise recovery.

Conclusion: A single bout of high-force eccentric exercise increases muscle fiber SC content and activation status in type II but not type I muscle fibers. 


\section{INTRODUCTION}

Satellite cells (SCs) are skeletal muscle precursor cells that reside between the basal lamina and sarcolemmal membrane of their associated muscle fibers. In adult muscle, SCs are normally mitotically and metabolically quiescent (30). However, SCs can become activated in response to various stimuli, including exercise. Following proliferation, SCs either differentiate donating their nuclei to existing myofibers, fuse together to form new myotubes or return to quiescence, thereby maintaining the resident basal pool of SCs through self-renewal $(6,12,40)$. In accordance, myonuclear and satellite cell (SC) content has been shown to increase in response to more prolonged exercise training, with a concomitant increase in muscle fiber size $(15,20,28,29,34,37)$.

During exercise training, SC activation, proliferation, and differentiation are key regulatory steps in the expansion of the $\mathrm{SC}$ pool that is required to allow for skeletal muscle reconditioning. Skeletal muscle SC content has been reported to increase by $30-150 \%$ after $24 \mathrm{~h}$ of recovery from a single bout of high-force eccentric exercise (7, 21, 26). Recent studies indicate that SC activation, proliferation, and differentiation following various stimuli are likely to occur in a fiber type specific manner $(32,34)$. However, it remains unknown whether acute exercise produces muscle fiber type specific changes in SC content.

In advance of proliferation, SCs must become activated from the quiescent state. Recent work has provided several markers to determine the number of active SCs in human skeletal muscle tissue. Markers such as $\operatorname{DLK1}(5,8,20,39), \operatorname{Ki}-67(19,24)$ and PCNA (21) have been applied to evaluate the activation status of the SC pool in vivo in human skeletal muscle. In line with previous comments, no data are presently available regarding potential fiber type specific activation of SCs during recovery from a single bout of high-force eccentric exercise. Moreover, various types of exercise show different fiber type recruitment patterns and, depending on the intensity of the exercise, display large differences in type I or II muscle fiber recruitment (25). High-force eccentric exercise is generally associated with more selective type II muscle fiber recruitment $(25,26)$ and type II muscle fiber damage $(9,10,38)$. Therefore, we tested the hypothesis that a single bout of high-force eccentric exercise would lead to a more specific type II muscle fiber dependent increase in SC activation status and subsequent SC enumeration.

To assess whether SCs are activated in a fiber type specific fashion we enumerated SCS following a high intensity eccentric leg extension protocol known to selectively activate type II fibers to a greater degree. For the first time we demonstrate that high force eccentric exercise activates SCs in a fiber type dependent manner, resulting in a fiber type specific increase in SC content following $24 \mathrm{~h}$ of post-exercise recovery. 


\section{MethodS}

\section{Subjects}

Nine healthy, active men ( $23 \pm 1 \mathrm{y} ; 73 \pm 2 \mathrm{~kg} ; 1.79 \pm 0.01 \mathrm{~m}$ ) were recruited for the study. All subjects were habitually engaged in a variety of recreational exercise pursuits but none were trained in any particular sporting event. Their peak oxygen uptake (VO2peak), determined using on-line gas collection system (Moxus Modular VO2 System, AEI Technologies, Inc., Pittsburgh, PA) during a ramp test to exhaustion on an electronically braked cycle ergometer (Lode BV, Excalibur Sport V2.0, The Netherlands), was $52 \pm 3 \mathrm{~mL} \bullet \mathrm{kg}^{-1} \bullet \mathrm{min}^{-1}$. Subjects were informed about the nature and risks of the experimental procedures before written consent was obtained. The experimental protocol was approved by the Hamilton Health Sciences/Faculty of Health Sciences Research Ethics Board and conformed to all declarations on the use of human subjects as research participants.

\section{Experimental protocol}

Subjects initially reported to the laboratory on several occasions to become familiar with the experimental procedures and measurement devices. At least one wk following familiarization, subjects returned to the laboratory for a needle biopsy sample from the vastus lateralis muscle of a randomized leg. At least one wk following the pre-exercise (baseline) biopsy, subjects performed an acute bout of high-force eccentric exercise using a protocol (2) previously shown to induce ultrastructural muscle damage and reduced volitional force-generating capacity. Twenty-four hours following cessation of exercise, subjects returned to the lab for a post-exercise needle biopsy.

\section{Exercise protocol}

The exercise protocol consisted of 300 high-force eccentric actions of the knee extensors performed on an isokinetic dynamometer (Biodex-System 3, Biodex Medical Systems, Inc., NY, USA). The protocol was based on the work of Beaton and colleagues (2) and was divided into 15 sets of 20 repetitions at a speed of $0.52 \mathrm{rad} / \mathrm{s}$ with $1 \mathrm{~min}$ rest intervals between sets.

\section{Physical activity and nutritional controls}

Subjects maintained their habitual diet over the course of the experiment. Diet was recorded for $24 \mathrm{~h}$ prior to and over the course of the pre-exercise measurements and food intake patterns were replicated prior to and during the post-exercise measurement period. All muscle biopsies were performed in the morning following an overnight fast. Subjects refrained from caffeine ingestion and alcohol for $24 \mathrm{~h}$ prior to the pre and post-exercise measurement periods. Subjects also refrained from using any nonsteroidal anti-inflammatory drugs (NSAID) between the pre and post-exercise measurement periods. Subjects did not perform any exhaustive physical activity for $48 \mathrm{~h}$ 
prior to the pre-exercise measurements and the high-force eccentric exercise trial. Preexercise and $24 \mathrm{~h}$ post-exercise measurements for a given subject were collected at the exact same time of day.

\section{Muscle biopsy sampling}

Muscle biopsies were obtained from the middle region of the vastus lateralis muscle 15 $\mathrm{cm}$ above the patella and approximately $2 \mathrm{~cm}$ deep to the fascia by means of the percutaneous needle biopsy technique described by Tarnopolsky et al (33). Muscle biopsies were taken before and $24 \mathrm{~h}$ following the single bout of high-force eccentric exercise. Muscle biopsies were carefully freed from any visible fat and blood. Thereafter, $\sim 40 \mathrm{mg}$ tissue was embedded in Tissue-Tek (OCT, Tissue-Tek, Sakura Finetek, USA) and rapidly frozen in liquid nitrogen cooled isopentane. Muscle biopsies were stored at -80 o $C$ for subsequent histochemical analysis to determine myocellular characteristics.

\section{Immunohistochemical analysis}

Using a cryostat at $-20^{\circ} \mathrm{C}$, all muscle biopsy samples were oriented in a cross-sectional direction and were cut in $5 \mu \mathrm{m}$ sections. For each subject, muscle samples collected at pre- and $24 \mathrm{~h}$ post-exercise were mounted together on uncoated glass slides, and allowed to air-dry for $30 \mathrm{~min}$ at room temperature before being stored at $-20 \circ \mathrm{C}$ for subsequent analyses. Muscle cross-sections were stained for SC content and activation status using primary antibodies against CD56 (BD biosciences, San Jose, CA; dilution 1:40), Pax7 (neat; Developmental Studies Hybridoma Bank [DSHB], lowa City, IA), DLK1 (monoclonal Anti-human Pref-1/DLK1/FA1 antibody; R\&D systems, Minneapolis, USA; dilution 1:50), Ki-67 (Monoclonal Ki-67; Biocare Medical, Concord, CA, USA; dilution 1:200), and PCNA (ab15497, Abcam Inc., USA; dilution 1:200). In addition, crosssections were stained for muscle fiber typing using primary antibodies against MHC-I (A4.951, [DSHB], lowa City, IA; dilution 1:20) and laminin (polyclonal rabbit anti-laminin; Sigma, Zwijndrecht, The Netherlands; dilution 1:50). Secondary antibodies used were: goat anti-mouse IgG1/IgG (AlexaFluor488, Invitrogen, Molecular Probes Inc., USA, (dilution 1:200), goat anti-mouse IgG2b (Alexa555, dilution 1:500), goat anti-rabbit IgG (Alexa555, dilution 1:500), goat anti-rabbit IgG (Alexa350, dilution 1:133), goat anti-rat IgG (Alexa350, dilution 1:133) and goat anti-rabbit biotinylated IgG (Vector Labs, dilution 1:200) followed by streptavidin conjugated (Alexa594, Invitrogen Canada, dilution 1:200). Nuclei were stained with 4,6-diamidino-2-phenylindole (DAPI; Molecular Probes; $0.238 \mu \mathrm{M})$.Muscle fiber type staining was performed as described previously (34-36). Briefly, after acetone fixation, muscle cross-sections were incubated for $60 \mathrm{~min}$ at room temperature with anti-laminin and anti-MHC-I, diluted in $0.05 \%$ Tween-PBS. Slides were then washed ( $3 \times 5 \mathrm{~min} 1 \times \mathrm{PBS})$ and incubated for $30 \mathrm{~min}$ at room temperature with the appropriate secondary antibodies diluted together with DAPI $(0.238 \mu \mathrm{M})$ in $0.05 \%$ Tween-PBS. 

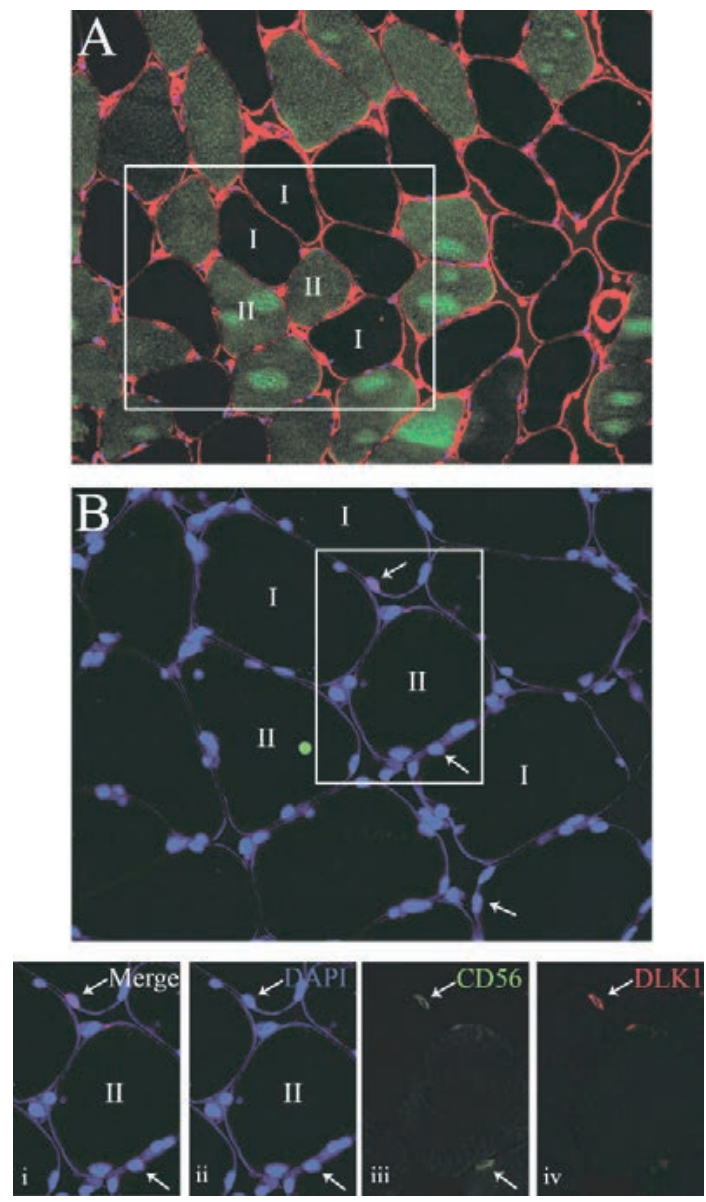

Figure 1 Representation of fiber type-specific analyses of skeletal muscle satellite cell content and activation status. (A) MHC-I+Laminin+Dapi staining from serial section of $B$; the marked area in $A$ represents the same area as presented in frame B. The marked area in B is the same area as in i-iv. (i) Dapi+laminin+CD56+DLK1. (ii) Dapi+laminin. (iii) CD56 only. (iv) DLK1 only. Numbers indicate the type I and II muscle fibers. Image i-iv illustrates a CD56+/DLK1+ nucleus (top arrow) and a CD56+ nucleus (bottom arrow).

After a final wash, slides were mounted with cover-slips using Mowiol (Calbiochem, Amsterdam, The Netherlands). The latter resulted in laminin stained in red, nuclei in blue, and MHC-I in green (Figures 1 and 2).For the muscle fiber type specific identification and co-localization of SCS (CD56) with DLK1 or Ki-67, serial muscle cross-sections of the muscle fiber type slides were fixated in acetone $\left(5 \mathrm{~min}\right.$ ) and then incubated at $4^{\circ} \mathrm{C}$ for $24 \mathrm{~h}$ with anti-CD56 and DLK1 or only anti-CD56 diluted in $0.05 \%$ Tween-PBS. Following incubation, slides were washed ( $3 \times 5$ min 1xPBS) and incubated for 30 min with the 

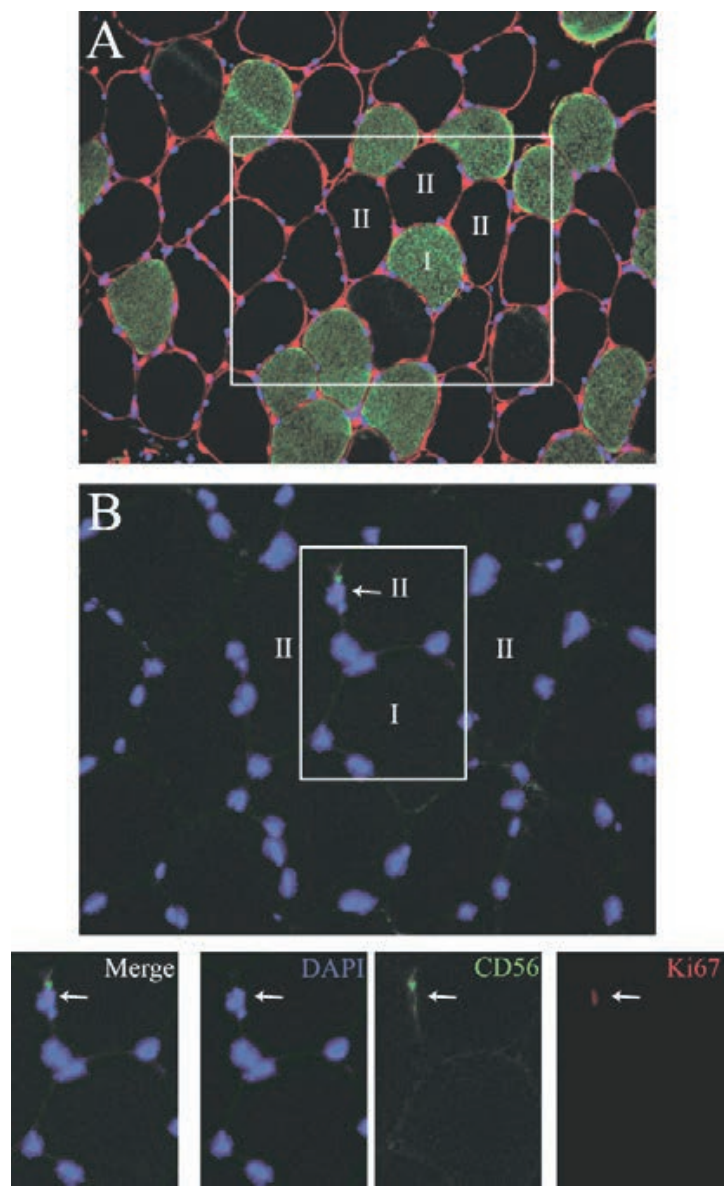

Figure 2 Representative image of a human muscle cross-section stained with CD56, Ki-67 and DAPI. Area inside the box is separated to show (i) Dapi+CD56+Ki67, (ii) Dapi (iii) CD56 only, (iv) Ki-67 only. Image i-iv illustrates a CD56+ nucleus positive for Ki-67. Scale bar $=50 \mu \mathrm{m}$.

appropriate secondary antibodies diluted in 0.05\% Tween-PBS. Slides were then washed and incubated at room temperature with anti-laminin, or anti-laminin with anti-Ki-67 diluted in 0.05\% Tween-PBS, for 60 and 120 min respectively. Following incubation, slides were again washed and incubated for $30 \mathrm{~min}$ with appropriate secondary antibodies, diluted together with DAPI $(0.283 \mu \mathrm{M})$ in $0.05 \%$ Tween-PBS. After a final wash, slides were mounted with cover-slips using Mowiol. This staining procedure resulted in laminin stained in blue, nuclei in blue, CD56 in green, and DLK1 or Ki-67 in red (Figures 1 and 2). For the identification and co-localization of mixed muscle fiber SCs (Pax7) with PCNA, muscle sections were co-stained with cell-cycle marker PCNA. Staining procedures were as described previously (21). Briefly, following blocking (10\% goat 
serum; GS), sections were incubated with anti-Pax7 overnight at $4^{\circ} \mathrm{C}$, washed and then incubated with the appropriate secondary antibody. After re-blocking in 5\% GS, slides were incubated with anti-PCNA overnight. After several washes (1xPBS), sections were incubated in the appropriate secondary antibodies for $2 \mathrm{~h}$. Sections were then washed, incubated with DAPI, and then washed and mounted with a fluorescent mounting medium (Dako, Canada Inc., Canada). This staining procedure resulted in nuclei in blue, Pax7 in green, and PCNA in red (Figure 3).
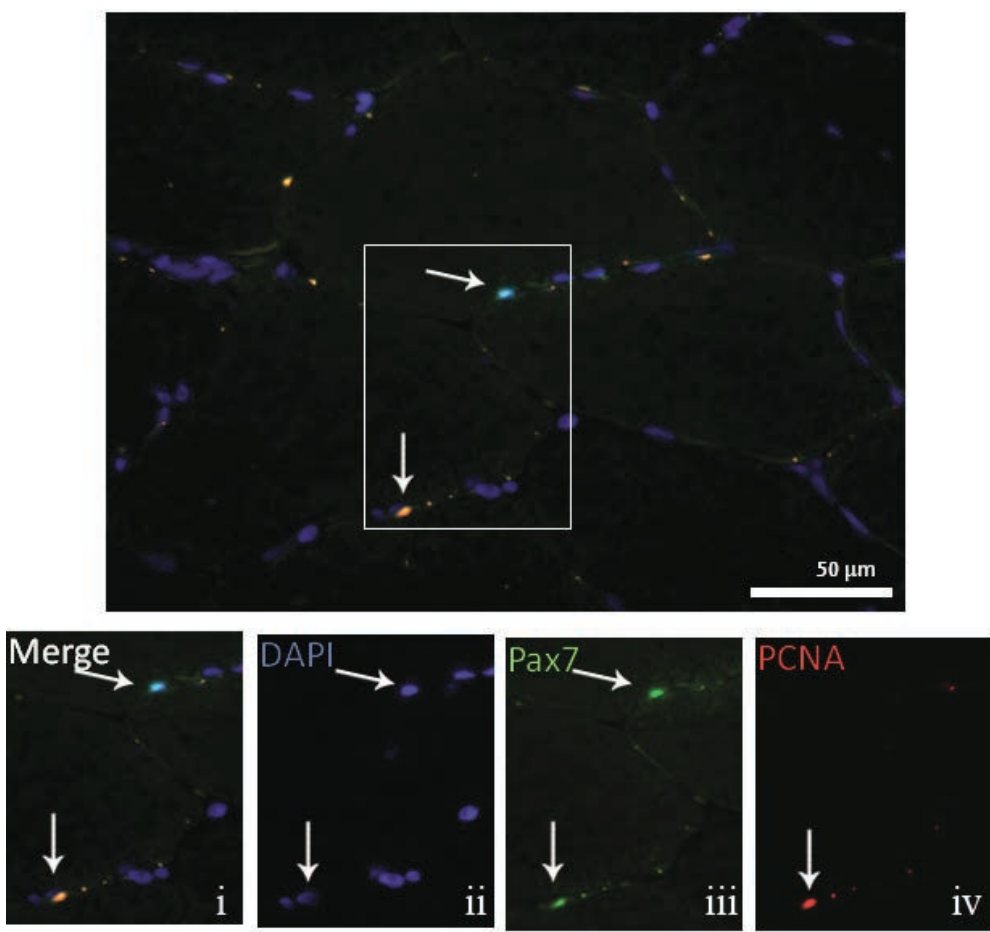

Figure 3 Representative image of a human muscle cross-section stained with Pax7, PCNA and DAPI. Area inside the box is separated to show (i) Dapi+Pax7+PCNA. (ii) Dapi. (iii) only Pax7. (iv) only PCNA. Image i-iv illustrates a Pax7+ nucleus negative for PCNA (top arrow) and a Pax7+/PCNA+ nucleus (bottom arrow). Scale Bar $=50 \mu \mathrm{m}$.

\section{Data analyses}

RGB-images were recorded and processed as described previously using a Nikon E800 fluorescence microscope (Nikon Instruments Inc., Europe) or a Nikon Eclipse 90i Microscope (Nikon Instruments Inc., USA). All image recordings and analyses were performed by an investigator blinded to subject coding and/or study design and staining specificity was determined with the appropriate negative controls for each stain. 
Images from fiber type stained muscle cross-sections were captured at a 20x objective. Within each image, the number of fibers, the mean fiber cross-sectional area (CSA), the number of myonuclei per fiber, and the mean fiber area per nucleus (fiber CSA/\#myonuclei) were assessed for type I and II muscle fibers. Fiber circularity was calculated as $(4 \pi \cdot \mathrm{CSA}) /(\text { perimeter })^{2}$. No differences in fiber circularity were observed over time or between fiber types. For mixed muscle and fiber type specific SC analyses, images were captured at a 40x objective to allow clear SC localization. Laminin was used to visualize the basement membrane. Fiber typing was determined by matching the serial muscle fiber type slides. SCs were determined at the periphery of each fiber and stained positive for both DNA (DAPI) and CD56 or Pax7. The number of SCs per muscle fiber was calculated for mixed muscle and type I and II muscle fibers separately. To determine the activation status, co-localization of SCs with cell-cycle markers DLK1, $\mathrm{Ki}-67$, or PCNA was assessed in all muscle samples. Mixed muscle DLK1+, Ki-67+ and PCNA+ SCs per muscle fiber were calculated. The proportion of SCs staining positive for DLK1, Ki-67 or PCNA [\#SCs staining positive for DLK1, Ki-67, or PCNA/ \#SCs] were then calculated. In addition, the number and proportion of DLK1+ and Ki-67+ SCs were also calculated for type I and type II muscle fibers separately. We were unable to reliably quantify fiber type specific SCs and Ki-67 in 1 subject and DLK1 in 2 subjects. An average of $424 \pm 53$, and $440 \pm 34$ muscle fibers were analyzed for muscle fiber typing and $279 \pm 77$ and $296 \pm 82$ muscle fibers were used to assess SC content and activation status in each muscle biopsy sample collected prior to exercise and after $24 \mathrm{~h}$ of post-exercise recovery.

\section{Statistical analyses}

All mixed muscle fiber data were analyzed using a two-tailed paired t-test (Sigma Stat 3.1, Point Richmond, California). All fiber type specific data were analyzed using a twofactor (fiber type $x$ time) repeated measures analysis of variance (ANOVA). The level of significance for all analyses was set at $P<0.05$ and significant interactions and main effects were subsequently analyzed using a Tukey post hoc test.

\section{RESULTS}

\section{Muscle fiber type distribution and fiber area}

Muscle fiber type composition was $44 \pm 5 \%$ type I and $56 \pm 5 \%$ type II muscle fibers. The proportion of muscle fiber area occupied by type I and type II muscle fibers was $37 \pm 5$ and $63 \pm 5 \%$, respectively. Muscle fiber area was significantly greater in type II compared with type I fibers (6833 \pm 611 vs $6039 \pm 478 \mu \mathrm{m}^{2}$, respectively; $P<0.05$ ). No differences were observed in fiber type distribution and/or muscle fiber size before exercise and after $24 \mathrm{~h}$ of recovery from the single bout of high-force eccentric exercise (Table 1 ). 

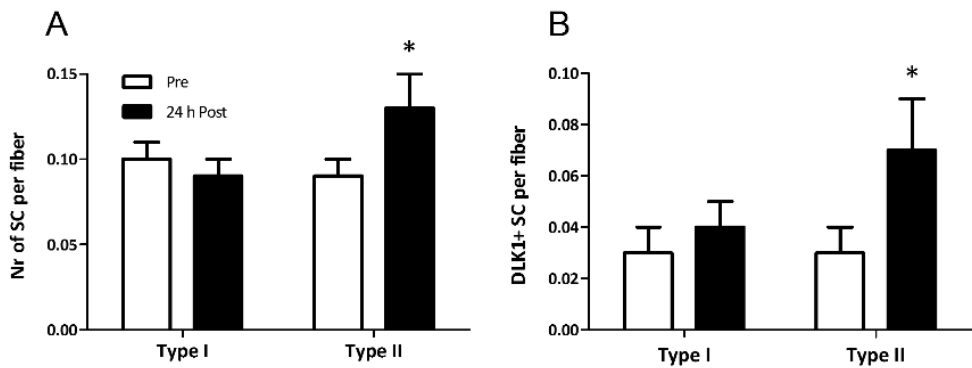

\begin{abstract}
Figure 4 Mean number of satellite cells (SC) in type I and type II muscle fibers before (pre) and 24 $\mathrm{h}$ after (post) 300 high-force eccentric actions of the knee extensors (A). Mean number of satellite cells (SC) in type I and II muscle fibers that stained positive for DLK1 before (pre) and $24 \mathrm{~h}$ after (post) 300 high-force eccentric actions of the knee extensors (B). *Significantly different compared with pre-exercise value $(P<0.05)$; Values are means \pm SEM.
\end{abstract}

\title{
Myonuclear and satellite cell content
}

No changes in mixed muscle myonuclear content and myonuclear domain size were observed between pre and $24 \mathrm{~h}$ post-exercise samples (Table 1). Furthermore, when expressed per fiber type, myonuclear content and myonuclear domain showed no significant changes over time (Table 1). For mixed muscle, the number of SCs per muscle fiber did not change after $24 \mathrm{~h}$ of recovery (from $0.091 \pm 0.009$ to $0.114 \pm 0.011$, respectively; $P=0.15)$. However, when SC content was expressed in a fiber type specific manner the number of SCs per type II muscle fiber increased significantly after $24 \mathrm{~h}$ of recovery (from $0.085 \pm 0.012$ to $0.133 \pm 0.016$, respectively; $P<0.05$; Figure $4 \mathrm{~A}$ ) whereas no changes in type I muscle fiber SC content were observed (Figure 4A).

\section{Satellite cell activation status}

DLK1: Pre-exercise mixed muscle DLK1 expression was observed in $38 \pm 9 \%$ of all SCs. The number of SCs expressing DLK1 per muscle fiber increased significantly over time (from $0.029 \pm 0.006$ to $0.057 \pm 0.011$, respectively $P<0.05$ ). When the number of DLK1+ SCs was expressed per muscle fiber type, no significant differences were observed between type I and type II muscle fibers at baseline $(0.034 \pm 0.007$ and $0.027 \pm 0.008$, respectively). However, $24 \mathrm{~h}$ after exercise, the number of SCs expressing DLK1 had increased in the type II muscle fibers only (from $0.027 \pm 0.008$ to $0.070 \pm 0.017$, respectively; $P<0.01$; Figure 4B).

Ki-67: No Ki-67+ SCs were observed in any of the pre-exercise samples. No significant changes in the percentage of SCs expressing Ki-67 were observed over time. In the muscle biopsy samples obtained after $24 \mathrm{~h}$ of post-exercise recovery, Ki-67 protein expression became apparent in 4 out of 8 subjects. Three out of these 4 subjects showed a 4-20\% increase in Ki-67+ SCs in the type I or II muscle fibers, whereas one subject revealed a $42 \%$ and $78 \%$ increase in the percentage of SCs expressing Ki-67 in 
the type I and type II muscle fibers respectively, following $24 \mathrm{~h}$ of post-exercise recovery.

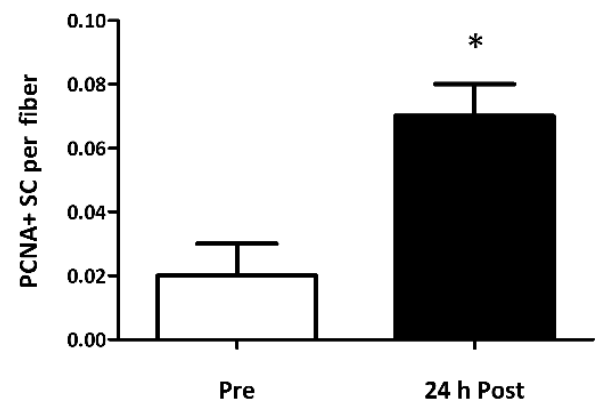

Figure 5 Mean number of satellite cells (SC) in mixed muscle fibers that stained positive for PCNA before (pre) and $24 \mathrm{~h}$ after (post) 300 highforce eccentric actions of the knee extensors. *Significantly different compared with preexercise value $(P<0.01)$. Values are means \pm SEM.

PCNA: In the pre-exercise samples, $13 \pm 3 \%$ of the SCs expressed PCNA. The percentage of SCs stained positive for PCNA increased significantly $24 \mathrm{~h}$ following high-force eccentric exercise (from $13 \pm 3$ to $34 \pm 3 \%$; $P<0.001$ ). In accordance, the number of PCNA+ SCS expressed per muscle fiber increased from pre to $24 \mathrm{~h}$ post-exercise $(0.02 \pm 0.01 \mathrm{vs}$. $0.07 \pm 0.01$, respectively; $P<0.05$; Figure 5).

\section{DISCUSSION}

The present study is the first to demonstrate that a single bout of high-force eccentric exercise activates SCs and augments SC content following $24 \mathrm{~h}$ of post-exercise recovery in a muscle fiber type specific manner. Twenty-four hours following a single session of high-force eccentric exercise, type II muscle fiber SC activation status was increased and accompanied by a $73 \pm 29 \%$ increase in SC number whereas type I muscle fibers showed no changes in SC activation status or content.

In the present study, we assessed the impact of a single session of high-force eccentric exercise on subsequent SC activation and enumeration in a muscle fiber type dependent manner. We particularly selected eccentric exercise, as this has been reported to result in selective recruitment $(25,26)$ and damage of the type II muscle fibers $(9,10$, $38)$. In the present study, mixed muscle SC content tended $(P=0.15)$ to increase following $24 \mathrm{~h}$ of post-exercise recovery. Previous work has either reported a measurable (7, $21,23,27$ ) or no measurable (20) increase in SC content following $24 \mathrm{~h}$ of recovery from a single bout of exercise. The apparent discrepancy in the literature is likely attributed to the lack of fiber type specificity in the assessment of SC content in these studies. Many of the changes in SC content in senescent muscle (36) or following prolonged resistance-type exercise training $(34,37)$ are fiber type specific. Therefore, it is important to consider fiber type specific changes in SC content as demonstrated in the present investigation. Despite the lack of significant changes in mixed muscle SC con- 
tent, we observed a substantial $73 \pm 29 \%$ increase in type II muscle fiber SC content (Figure 4). In contrast, no changes could be observed in type I muscle fiber SC content. These findings imply that previous reported findings on the proposed impact of exercise on subsequent expansion of the SC pool may have been hampered by the lack of fiber type dependent analyses. Clearly, the observation of such a fiber type specific impact of eccentric exercise on the increase in the SC content punctuates the need for the acquisition of fiber type specific data.

Satellite cell activation is a necessary component of the myogenic program in advance of division. Therefore, in the present study we also assessed fiber type specific SC activation status in muscle biopsy samples taken before exercise and after $24 \mathrm{~h}$ of postexercise recovery. Various tissue markers have been suggested to identify the activation status of SCs by immunohistological staining $(14,19-21)$. DLK1 is a member of the epidermal growth factor super-family and is believed to play an important role in skeletal muscle myogenesis (8). Previous in vivo studies in humans have already shown that DLK1 is co-localized within muscle SCs $(1,18,19)$. In addition, we have previously reported that the number of DLK1+ SCs increases within a post-exercise recovery period as short as $9 \mathrm{~h}$ (31). In the present study we observed no baseline differences in the number of DLK1+ SCs between type I and type II muscle fibers. A significant increase in DLK1+ SCs (199 $\pm 88 \%)$ was observed after $24 \mathrm{~h}$ of post-exercise recovery in the type II muscle fibers only. The greater number of SCs expressing DLK1 agrees with the type II muscle fiber type specific increase in SC content.

We further characterized fiber type specific SC activation status using cell markers Ki-67 and PCNA. Ki-67 is selectively expressed in cells during the active stages of the cell cycle (11) and has previously been successfully applied to assess SC activation status in skeletal muscle tissue $(4,19,24)$. These studies have demonstrated that during resting conditions, the number of proliferating SCs is quite low $(19,24)$. In accordance, we did not find any SCs co-expressing Ki-67 in our pre-exercise muscle samples. To date, only a few studies have examined the number of proliferating SCs using Ki-67 following exercise (24) or electrical stimulation (19). In the present study, we observed an increase in the number of Ki-67+ SCs in 4 out of the 8 subjects in both muscle fiber types. Consequently, no significant changes in the proportion of SCs expressing Ki-67 were observed $24 \mathrm{~h}$ after the single bout of eccentric exercise. However, the substantial rise in both SC content and the number of DLK1+ SCs implies that the proliferative drive of the SC pool may be increased. Therefore, we also used PCNA as an alternative marker that has previously been used to identify SCs during the active stages of the cell-cycle (21). To establish whether PCNA would yield different results in the present study we co-stained Pax7 with PCNA. We observed that $13 \pm 3 \%$ of the SCs were PCNA+ at baseline. Moreover, this proportion of PCNA+ SCs had increased significantly to $34 \pm 2 \%$ following $24 \mathrm{~h}$ of recovery. However, the PCNA protein has a relatively long half-life time $( \pm 20 \mathrm{~h})$ compared with the $\mathrm{Ki}-67$ protein $(60-90 \mathrm{~min})(3,13)$, which will likely result in the detection of 'residual' PCNA expression, even when the SCs are exiting the M Phase of the cell 
cycle. The latter may explain the difference between the Ki-67 and PCNA results observed in the current study. It could be speculated that PCNA does not merely represent a marker of SCs that are proliferating, but also detects those SCS that have undergone proliferation within a certain time frame prior to muscle biopsy collection. In fact, those SCs expressing PCNA may have already progressed further through the myogenic program, and thus may include SCs returning to quiescence (i.e. self-renewal) as well as SCs progressing towards terminal differentiation. Unfortunately, as fiber type specific staining for SCs with PCNA has so far proven unsuccessful we did not obtain fiber type specific data.

In the present study, we demonstrate a significant increase in SC number $24 \mathrm{~h}$ after performing an exercise bout composed of 300 eccentric actions. These data seem to be at odds with McKay et al. (22) who did not show a significant increase in the number of $\mathrm{SCS}$ in the $\mathrm{S}$ phase of the cell cycle until $48 \mathrm{~h}$ after performing a bout of resistance-type exercise ( 80 repetitions at $75 \%$ of 1 repetition maximum). In contrast, the presented data are supported by work from others $(7,27)$ as well as earlier studies by McKay and colleagues $(21,23)$, all of whom report significant increases in SC enumeration within $24 \mathrm{~h}$ after high-force eccentric exercise. Clearly, a lower-intensity concentric stimulus (75\% of subject's 1RM $\times 80$ contractions; (22) may not elicit the same level of response compared with higher-intensity eccentric stimuli (100\% MVC x 300 eccentric actions $(21,23)$. Consequently, it is more than likely that the mode of exercise, the contraction type, and the intensity level at which the exercise is performed modulate the level and timeline of post-exercise SC activation and enumeration.

Recent studies clearly indicate that fiber type specific changes in SC content and activation status are of considerable interest $(31,34,37)$. The present study shows that in response to a single bout of high-force eccentric exercise a substantial increase in SC activation status and a concomitant rise in SC content occurs in a type II muscle fiber specific manner. These results support the notion that SCs respond to anabolic stimuli in line with the expected fiber type recruitment pattern (38). The latter may have important clinical relevance to develop more effective nutritional and/or exercise interventions in an effort to modulate muscle structure and function in both health and disease with particular relevance concerning the preferential type II muscle fiber atrophy with aging $(16,17,36)$.

In conclusion, a single bout of high-force eccentric exercise induces a type II muscle fiber specific increase in SC activation and enumeration within $24 \mathrm{~h}$ of post-exercise recovery in young, healthy men. This study stresses the need for more fiber type specific assessment of SC activation, proliferation, and differentiation upon various anabolic stimuli in both health and disease. 


\section{REFERENCES}

1. Andersen D, Petersson S, Jørgensen L, Bollen P, Jensen $P$, Teisner B, Schroeder H, et al. Characterization of DLK1+ cells emerging during skeletal muscle remodeling in response to myositis, myopathies, and acute injury. Stem Cells 27: 898-908, 2009.

2. Beaton L, Allan D, Tarnopolsky M, Tiidus P, and Phillips S. Contraction-induced muscle damage is unaffected by vitamin E supplementation. Medicine and Science in Sports and Exercise 34: 798-805, 2002.

3. Bruno S, Gorczyca W, and Darzynkiewicz Z. Effect of ionic strength in immunocytochemical detection of the proliferation associated nuclear antigens p120, PCNA, and the protein reacting with Ki-67 antibody. Cytometry 13: 496-501, 1992.

4. Christov C, Chretien F, Abou-Khalil R, Bassez G, Vallet G, Authier FJ, Bassaglia Y, et al. Muscle satellite cells and endothelial cells: close neighbors and privileged partners. Mol Biol Cell 18: 1397-1409, 2007.

5. Crameri R, Langberg H, Magnusson P, Jensen C, Schroder H, Olesen J, Suetta C, et al. Changes in satellite cells in human skeletal muscle after a single bout of high intensity exercise. Journal of Physiology 558 : 333-340, 2004.

6. Dhawan J, and Rando T. Stem cells in postnatal myogenesis: molecular mechanisms of satellite cell quiescence, activation and replenishment. Trends in cell biology 15: 666-673, 2005.

7. Dreyer H, Blanco C, Sattler F, Schroeder T, and Wiswell R. Satellite cell numbers in young and older men 24 hours after eccentric exercise. Muscle \& Nerve 33: 242-253, 2006.

8. Floridon C, Jensen C, Thorsen P, Nielsen O, Sunde L, Westergaard J, Thomsen S, et al. Does fetal antigen 1 (FA1) identify cells with regenerative, endocrine and neuroendocrine potentials? A study of FA1 in embryonic, fetal and placental tissue and in maternal circulation. Differentiation 66: 49-59, 2000.

9. Friden J, and Lieber R. Structural and mechanical basis of exercise-induced muscle injury. Medicine and Science in Sports and Exercise 24: 521-530, 1992.

10. Friden J, Sjostrom M, and Ekblom B. Myofibrillar damage following intense eccentric exercise in man. International Journal of Sports Medicine 4: 170-176, 1983.

11. Gerdes J, Lemke H, Baisch H, Wacker H, Schwab $U$, and Stein H. Cell cycle analysis of a cell proliferationassociated human nuclear antigen defined by the monoclonal antibody Ki-67. J Immunol 133: 17101715, 1984.

12. Hawke T, and Garry D. Myogenic satellite cells: physiology to molecular biology. Journal of Applied Physiology 91: 534-551, 2001.

13. Heidebrecht H, Buck F, Haas K, Wacker H, and Parwaresch R. Monoclonal antibodies Ki-S3 and Ki-S5 yield new data on the 'Ki-67' proteins. Cell Proliferation 25: 413-425, 1996.

14. Kadi F, Charifi N, Denis C, Lexell J, Andersen J, Schjerling P, Olsen S, et al. The behaviour of satellite cells in response to exercise: what have we learned from human studies? Pflugers Arch 451: 319-327, 2005.

15. Kadi F, Schjerling P, Andersen L, Charifi N, Madsen J, Christensen L, and Andersen J. The effects of heavy resistance training and detraining on satellite cells in human skeletal muscles. The Journal of Physiology 558: 1005-1012, 2004.

16. Larsson L, Sjödin B, and Karlsson J. Histochemical and biochemical changes in human skeletal muscle with age in sedentary males, age 22--65 years. Acta Physiologica Scandinavica 103: 31-39, 1978.

17. Lexell J, Taylor C, and Sjöström M. What is the cause of the ageing atrophy? Total number, size and proportion of different fiber types studied in whole vastus lateralis muscle from 15- to 83-year-old men. Journal of the Neurological Sciences 84: 275-294, 1988.

18. Lindström M, Pedrosa-Domellöf $F$, and Thornell L. Satellite cell heterogeneity with respect to expression of MyoD, myogenin, Dlk1 and c-Met in human skeletal muscle: application to a cohort of power lifters and sedentary men. Histochemistry and cell biology 134: 371-385, 2010.

19. Mackey A, Kjaer M, Charifi N, Henriksson J, Bojsen-Moller J, Holm L, and Kadi F. Assessment of satellite cell number and activity status in human skeletal muscle biopsies. Muscle Nerve 40: 2009. 
20. Mackey A, Kjaer M, Dandanell S, Mikkelsen K, Holm L, Dossing S, Kadi F, et al. The influence of antiinflammatory medication on exercise-induced myogenic precursor cell responses in humans. Journal of Applied Physiology 103: 425-431, 2007.

21. McKay B, De Lisio M, Johnston A, O'Reilly C, Phillips S, Tarnopolsky M, and Parise G. Association of Interleukin- 6 signalling with the muscle stem cell response following muscle-lengthening contractions in humans. Plos One 4: 1-13, 2009.

22. McKay B, Ogborn D, Bellamy L, Tarnopolsky M, and Parise G. Myostatin is associated with age-related human muscle stem cell dysfunction. FASEB journal 2012.

23. McKay B, Toth K, Tarnopolsky M, and Parise G. Satellite cell number and cell cycle kinetics in response to acute myotrauma in humans: immunohistochemistry versus flow cytometry. Journal of Physiology 588: 3307-3320, 2010.

24. Mikkelsen U, Langberg H, Helmark I, Skovgaard D, Andersen L, Kjaer M, and Mackey A. Local NSAID infusion inhibits satellite cell proliferation in human skeletal muscle after eccentric exercise. Journal of Applied Physiology 107: 1600-1611, 2009.

25. Nardone A, Romanò C, and Schieppati M. Selective recruitment of high-threshold human motor units during voluntary isotonic lengthening of active muscles. Journal of Physiology 409: 451-471, 1989.

26. Nardone A, and Schieppati M. Shift of activity from slow to fast muscle during voluntary lengthening contractions of the triceps surae muscles in humans. Journal of Physiology 395: 363-381, 1988.

27. O'Reilly C, MCKay B, Phillips S, Tarnopolsky M, and Parise G. Hepatocyte growth factor (HGF) and the satellite cell response following muscel lengthening contractions in humans. Muscle Nerve 38: 14341442, 2008.

28. Petrella J, Kim J, Mayhew D, Cross J, and Bamman M. Potent myofiber hypertrophy during resistance training in humans is associated with satellite cell-mediated myonuclear addition: a cluster analysis. Journal of Applied Physiology 104: 1736-1742, 2008.

29. Roth S, Martel G, Ivey F, Lemmer J, Tracy B, Metter E, Hurley B, et al. Skeletal muscle satellite cell characteristics in young and older men and women after heavy resistance strength training. The journals of gerontology Series A, Biological sciences and medical sciences 56: B240-247, 2001.

30. Schultz E, Gibson $M$, and Champion $T$. Satellite cells are mitotically quiescent in mature mouse muscle: an EM and radioautographic study. J Exp Zool 206: 451-456, 1978.

31. Snijders T, Verdijk L, Beelen M, McKay B, Parise G, Kadi F, and van Loon L. A single bout of exercise activates skeletal muscle satellite cells during subsequent overnight recovery. Experimental physiology 97: 762-763, 2012

32. Snijders $T$, Verdijk L, and van Loon L. The impact of sarcopenia and exercise training on skeletal muscle satellite cells. Ageing Research Reviews 8: 328-338, 2009.

33. Tarnopolsky M, Pearce E, Smith K, and Lach B. Suction-modified Bergström muscle biopsy technique: experience with 13,500 procedures. Muscle \& Nerve 43: 717-725, 2011.

34. Verdijk L, Gleeson B, Jonkers R, Meijer K, Savelberg H, Dendale P, and van Loon L. Skeletal muscle hypertrophy following resistance training is accompanied by a fiber type-specific increase in satellite cell content in elderly men. The Journals of Gerontology Series A, Biological Sciences and Medical Sciences 64: 332-339, 2009.

35. Verdijk L, Jonkers R, Gleeson B, Beelen M, Meijer K, Savelberg H, Wodzig W, et al. Protein supplementation before and after exercise does not further augment skeletal muscle hypertrophy after resistance training in elderly men. American Journal of Clinical Nutrition 89: 608-616, 2009.

36. Verdijk L, Koopman R, Schaart G, Meijer K, Savelberg H, and van Loon L. Satellite cell content is specifically reduced in type II skeletal muscle fibers in the elderly. American Journal of Physiology Endocrinology and Metabolism 292: E151-E157, 2007.

37. Verney J, Kadi F, Charifi N, Feasson L, Saafi M, Castells J, Piehl-Aulin K, et al. Effects of combined lower body endurance and upper body resistance training on the satellite cell pool in elderly subjects. Muscle \& Nerve 38: 1147-1154, 2008. 
38. Vijayan K, Thompson J, Norenberg K, Fitts R, and Riley D. Fiber-type susceptibility to eccentric contraction-induced damage of hindlimb-unloaded rat AL muscles. Journal of Applied Physiology 90 : 770-776, 2001.

39. Waddell J, Zhang P, Wen Y, Gupta S, Yevtodiyenko A, Schmidt J, Bidwell C, et al. Dlk1 is necessary for proper skeletal muscle development and regeneration. PLoS One 5: e15055, 2010.

40. Zammit $P$, Partridge $T$, and Yablonka-Reuveni $Z$. The skeletal muscle satellite cell: the stem cell that came in from the cold. J Histochem Cytochem 54: 1177-1191, 2006. 
CHAPTER 6

\title{
The skeletal muscle satellite cell response to a single bout of resistance type exercise is delayed with aging in men
}

\author{
Tim Snijders \\ Lex B. Verdijk \\ Joey S.J. Smeets \\ Bryon R. McKay \\ Joan M.G. Senden \\ Fred Hartgens \\ Gianni Parise \\ Paul Greenhaff \\ Luc J.C. van Loon
}

AGE (Dord.) 2014 36: 9699 


\section{Abstract}

Introduction: Skeletal muscle satellite cells (SCs) have been shown to be instrumental in the muscle adaptive response to exercise. The present study determines age-related differences in SC content and activation status following a single bout of exercise.

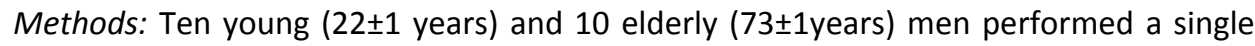
bout of resistance type exercise. Muscle biopsies were collected before and 12, 24, 48 and $72 \mathrm{~h}$ after exercise. SC content and activation status were assessed in type I and type II muscle fibers by immunohistochemistry. Myostatin and MyoD protein and messenger RNA (mRNA) expression were determined by Western blotting and rtPCR, respectively.

Results: In response to exercise, it took $48 \mathrm{~h}$ (young) and $72 \mathrm{~h}$ (elderly) for type II muscle fiber SC content to exceed baseline values $(P<0.01)$. The number of myostatin+ SC in type I and II muscle fibers was significantly reduced after 12,24 , and $48 \mathrm{~h}$ of postexercise recovery in both groups $(P<0.01)$, with a greater reduction observed at 24 and $48 \mathrm{~h}$ in the young compared with that in the elderly men $(P<0.01)$.

Conclusion: The increase in type II muscle fiber SC content during post-exercise recovery is delayed with aging and is accompanied by a blunted SC activation response. 


\section{INTRODUCTION}

The age-related loss of skeletal muscle mass is characterized by a reduction in muscle fiber cross-sectional area and number, and specific type II muscle fiber atrophy $(25,54)$. This decline in type II muscle fiber cross-sectional area is accompanied by a muscle fiber type-specific decline in the number of skeletal muscle satellite cells (SCs) (54). These SCs represent a small pool of myogenic precursor cells, which are essential for muscle fiber maintenance, repair, and growth. Although SCs typically reside in a quiescent state, they can become activated following exercise and/or skeletal muscle fiber damage $(32,37)$. Following activation, SCs can proliferate and subsequently differentiate to form new myonuclei, or return to a quiescent state to replenish the resident pool of SCs.

Physical activity has been shown to stimulate muscle protein synthesis, resulting in net muscle protein accretion $(41,57)$. However, it has been suggested that adequate SC activation, proliferation, and differentiation are required to allow substantial muscle fiber hypertrophy during more prolonged exercise training $(13,40)$. The progression of SCs through the various stages of activation, proliferation, and/or differentiation is mediated by the expression of different myogenic regulatory factors, or MRFs (MyoD, Myf-5, Myogenin, and Mrf4) (60). In addition, myostatin has been suggested to be of key importance in SC function during muscle fiber growth $(20,46)$. As a member of the transforming growth factor- $\beta$ (TGF- $\beta$ ) family, myostatin acts as a strong negative regulator of skeletal myogenesis $(22,35)$. It has been suggested that myostatin may be a crucial mediator in the age-related loss of muscle mass (46). An inability to properly downregulate myostatin may be of significant importance in the reduced myogenic capacity typically observed in aged human skeletal muscle in response to anabolic stimuli $(24,34)$. Likewise, the upregulation and/or downregulation of messenger RNA (mRNA) expression of the MRF proteins in response to a single bout of resistance type exercise has been shown to be altered in elderly $(6,10)$, which might be indicative of impairments in SC function in senescent muscle.

In support of a reduced SC responsiveness with aging, previous studies have indicated that the exercise-induced increase in SC content may be attenuated in the elderly. Dreyer et al. (2006) showed that $24 \mathrm{~h}$ following a single bout of eccentric exercise, the increase in SC content was greater in young $(+141 \%)$ when compared with that in elderly (+51\%) men. In a more recent study, McKay et al. (2012) assessed changes in type I and type II muscle fiber SC content during $48 \mathrm{~h}$ of post-exercise recovery in young and elderly men. This study showed that type II muscle fiber SC content increased in the young but not in the elderly men during the first $48 \mathrm{~h}$ of post-exercise recovery (34). The inability to properly increase the SC pool size in response to exercise might contribute to the reduced skeletal muscle adaptive response to exercise training that has typically been observed in the elderly $(18,39)$ and may predispose to the development of sarcopenia. Even though McKay et al. (2012) did not show any detectable increases 
in type II muscle fiber SC content following a single bout of exercise, it has been well established that in response to prolonged resistance type exercise training, type II muscle fiber hypertrophy is accompanied by a concomitant increase in type II muscle fiber SC content in healthy elderly $(23,52)$. So far, only limited data exist on the timedependent changes in SC content and activation status during post-exercise recovery in human skeletal muscle. A more comprehensive understanding of the timeline of the changes in SC activation, proliferation, and differentiation during post-exercise recovery in both young and elderly adults is required to understand the potential underlying mechanisms responsible for the blunted increase in muscle mass and strength observed in senescent muscle. Therefore, in the present study, we assessed type I and type II muscle fiber SC content and activation status following 12, 24, 48, and $72 \mathrm{~h}$ of recovery from a single bout of resistance type exercise in both young and elderly men. This is the first study to show that the increase in type II muscle fiber SC content is delayed and accompanied by a blunted SC activation response in healthy elderly men.

\section{Methods}

\section{Participants}

Ten healthy young ( $22 \pm 1$ years) and 10 healthy elderly ( $73 \pm 1$ years) men were recruited to participate in this study. Participants were informed about the nature and risks of the experimental procedures before their written consent was obtained. The study was approved by the Medical Ethical Committee of the Maastricht University Medical Centre+, and complied with the guidelines set out in the Declaration of Helsinki. Medical history of all participants was evaluated and a resting electrocardiogram was performed before selection. Exclusion criteria were defined that would preclude successful participation in the exercise session, which included (silent) cardiac or peripheral vascular disease and orthopedic limitations. Body composition (fat and fat-free mass) was determined by Dual Energy X-Ray Absorptiometry scan (DEXA; Hologic Inc., Bedford, USA). Lean mass and percentage body fat were determined on a whole body level and for specific regions (e.g., trunk and legs). Next, all eligible men participated in an orientation trial to become familiarized with the resistance type exercise protocol and the equipment. Proper lifting technique was demonstrated and then practiced by the participants for each of the two lower-limb exercises (leg press and leg extension). Subsequently, maximal strength (one-repetition maximum, or 1-RM) was determined by using the multiple repetitions testing procedure during two separate visits (28).

\section{Protocol}

At 08:00 h, following $24 \mathrm{~h}$ of a controlled diet, participants reported to the lab after an overnight fast. Following $30 \mathrm{~min}$ of supine rest, a muscle biopsy was taken from the $\mathrm{M}$. vastus lateralis. Thereafter, participants were provided with a standardized breakfast. 
After breakfast, participants rested for 30 min after which they performed a single bout of exercise. The single bout of resistance type exercise consisted of two different exercises. Participants performed 6 sets of 10 repetitions at 75\% 1-RM on the horizontal leg press machine (Technogym BV, Rotterdam, The Netherlands) and six sets of 10 repetitions at 75\% 1-RM on the leg extension machine (Technogym BV). A resting period of 2 min between sets was allowed. The entire protocol required approximately $40 \mathrm{~min}$ to complete. All participants were verbally encouraged during the test to complete the whole protocol. Before and after the exercise session, a 5-10 min warm up/cooling down at low intensity was performed on a cycle ergometer. At the end of the exercise protocol, the participants rested for $3 \mathrm{~h}$ in a supine position. At 12:30 h, participants received a standardized lunch, after which participants were provided with a standardized dinner for the same evening. At 20:30 h, participants reported back to the laboratory for collection of a muscle biopsy and blood sample ( $t=12 \mathrm{~h}$ ). Exactly 24,48 , and 72 $\mathrm{h}$ after the start of the exercise, a third, fourth, and fifth muscle biopsy and blood sample were collected.

\section{Diet and physical activity standardization}

During the entire 4-day intervention period, all participants consumed a controlled diet. Participants' energy requirements were calculated using the Harris and Benedict equations with a physical activity index of 1.4 (11). On average, the young men consumed $150 \pm 6 \mathrm{~kJ} \cdot \mathrm{kg} \mathrm{bw}^{-1} \cdot \mathrm{d}^{-1}$, consisting of $70 \pm 1 \mathrm{En} \%$ carbohydrate, $13 \pm 1 \mathrm{En} \%$ protein (equal to $1.16 \pm 0.03 \mathrm{~g}$ protein $\left.\cdot \mathrm{kg} \mathrm{bw}^{-1} \cdot \mathrm{d}^{-1}\right)$ and $20 \pm 1 \mathrm{En} \%$ fat. Elderly men consumed $125 \pm 4 \mathrm{~kJ} \cdot \mathrm{kg}$ $\mathrm{bw}^{-1} \cdot \mathrm{d}^{-1}$, consisting of $65 \pm 1 \mathrm{En} \%$ carbohydrate, $15 \pm 1 \mathrm{En} \%$ protein (equal to $1.11 \pm 0.04 \mathrm{~g}$ protein $\cdot \mathrm{kg} \mathrm{bw}^{-1} \cdot \mathrm{d}^{-1}$ ) and $22 \pm 1 \mathrm{En} \%$ fat. All volunteers were instructed to refrain from any sort of heavy physical exercise $3 \mathrm{~d}$ before the first test day until the day of the last blood and muscle biopsy sampling.

\section{Muscle biopsy}

Muscle biopsies were obtained from the middle region of the vastus lateralis muscle, $\sim 15 \mathrm{~cm}$ above the patella and approximately $2 \mathrm{~cm}$ away from the fascia by means of the percutaneous needle biopsy technique described by Bergström et al. (1975). Muscle biopsies were carefully freed from any visible fat and blood, with one part embedded in Tissue-Tek (Sakura Finetek Europe B.V., Zoeterwoude, Netherlands) and rapidly frozen in liquid nitrogen cooled isopentane, while another part was directly frozen in liquid nitrogen and stored at -80 oc for subsequent histochemical and biochemical analysis, respectively. 

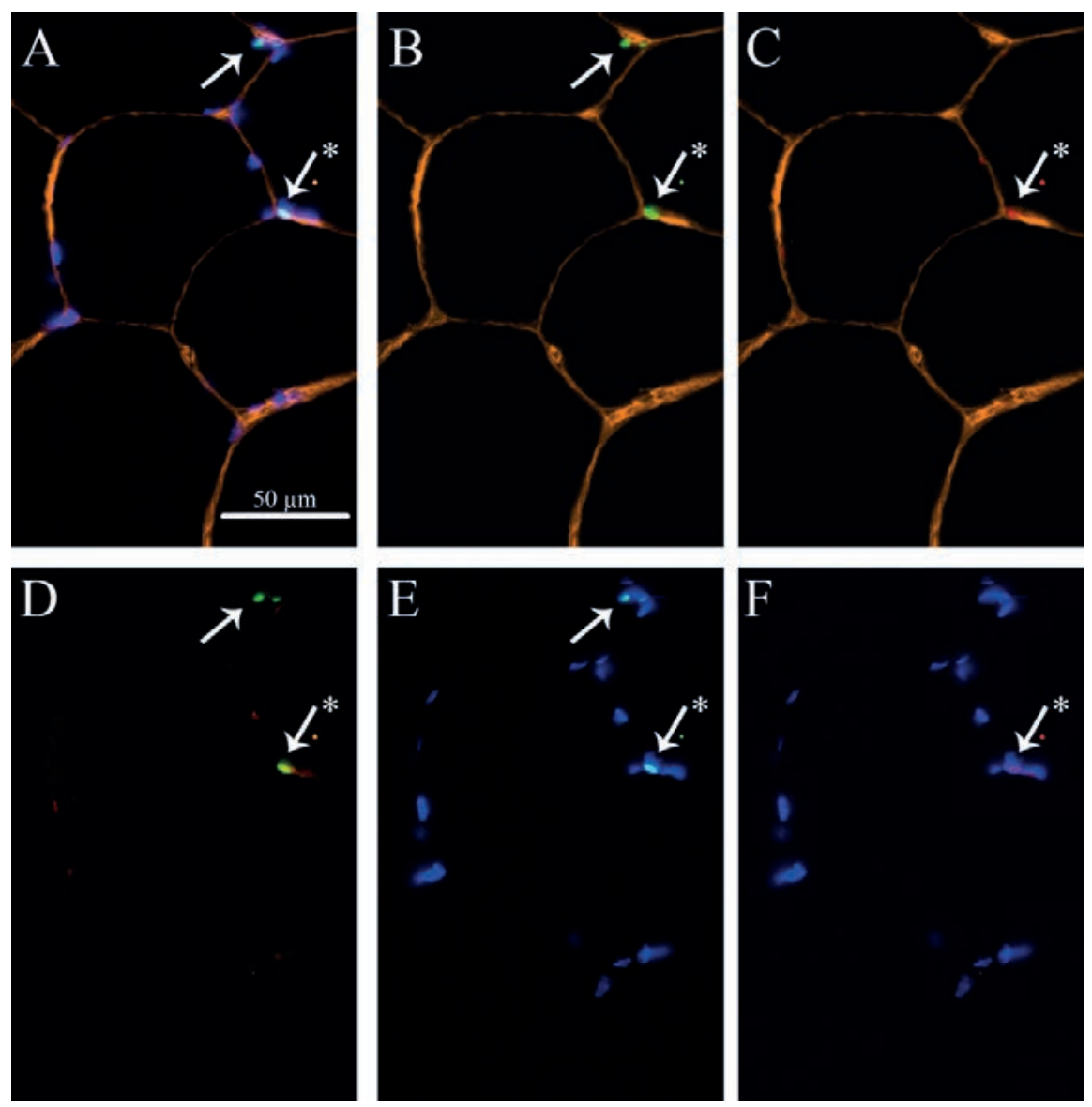

Figure 1 Representation of skeletal muscle satellite cells (SC) and MyoD in mixed muscle fibers. A: Laminin (yellow) + Dapi (blue) + Pax7 (green) + MyoD (red). B: Laminin + Pax7. C: Laminin + MyoD. D: Pax7 + MyoD. E: Dapi + Pax7. F: Dapi + MyoD. Arrows point at SCs. Asterisk indicates an activated SC.

\section{Immunohistochemical analysis}

From all muscle biopsy samples, 5 - $\mu$ m-thick cross-sections were cut at -20 oc using a cryostat. Muscle samples collected before and after 12, 24, 48, and $72 \mathrm{~h}$ of postexercise recovery from each individual participant were mounted together on uncoated glass slides and air-dried for $3 \mathrm{~h}$ at room temperature before being stored at -20 o $\mathrm{C}$ for subsequent analyses. All muscle cross sections were stained with antibodies against Pax7 (supernatant from growing cells; neat; DSHB), myostatin (near C-terminus; 1:100; AB3239; Millipore, Etobicoke, ON, Canada) previously validated to detect the Cterminal (active) myostatin (2, 12); MyoD1 (anti-MyoD1; clone 5.8A; Dako, Burlington, ON, Canada); A4.951 [myosin heavy chain type I ( $\mathrm{MHCl}$; slow isoform); supernatant; neat; DSHB], and laminin (1:1000; L8271, Sigma- Aldrich, Oakville, ON, Canada, and Abcam ab11575, Abcam, Cambridge, MA, USA). Appropriate secondary antibodies were 
applied: Dylight 488 (1:500, Thermo Scientific, Ontario, ON, Canada), Alexa Fluor 594, (1:500, Invitrogen, Molecular Probes, Carlsbad, CA, USA), biotinylated secondary antibody, (1:200; Vector Canada, Burlington, ON, Canada) streptavidin-594 fluorochrome (1:500; Invitrogen, Molecular Probes), Alexa Fluor 488 (1:500), Alexa Fluor 594 (1:500), and Alexa Fluor 647 (1:500); Alexa Fluor 350 (1:20), Alexa Fluor 488 (1:500), Alexa Fluor 647 (1:500). The immunohistochemical staining procedures were adapted from previously published methods $(34,48)$. All stained muscle samples were viewed with the Nikon Eclipse 90i microscope outfitted with a high-resolution QImaging camera for fluorescence detection (Nikon Instruments, Melville, NY, USA), and images were captured with a 40X objective and analyzed using the Nikon NIS Elements AR 3.0 software (Nikon Instruments). Fiber circularity was calculated as $(4 \pi \bullet$ cross-sectional area (CSA)/(perimeter) ${ }^{2}$. For each subject, fiber type distribution (fiber\%: number of type I fibers/total fiber number), fiber CSA fiber area percentage (CSA\%: the area percentage occupied by type I fibers, calculated by multiplying type I fiber\% and type I CSA, and then dividing by total area), number of SCs per fiber, and number of SC per square millimeters of muscle fiber area were determined for the type I and type II muscle fibers, separately. In addition, we determined the number of SC stained positive for MyoD or Myostatin (see Figure 1 and 2 for representative images of the immunohistological analyses, respectively). As described previously (26), at least 75 type I and 75 type II muscle fibers were included to make a reliable estimation of SC content in human muscle biopsy samples (Table 1). Slides were masked for both groups and time points. Due to technical difficulties, MyoD+ SCs were only assessed in mixed muscle fiber in 14 out of 20 participants ( 6 young and 8 elderly men), whereas the number of myostatin+ SCs was determined in type I and type II muscle fibers separately in all participants (10 young and 10 elderly men). Representative images of the immunohistological analyses are provided in Figures 1 and 2.

Table 1 Characteristic of immunohistological analyses

\begin{tabular}{lccccc}
\hline & \multicolumn{3}{c}{ Young } & \multicolumn{2}{c}{ Old } \\
\cline { 2 - 5 } Fiber number & & Type I & Type II & Type I & Type II \\
\cline { 2 - 5 } & Pre & $112 \pm 10$ & $109 \pm 8$ & $103 \pm 18$ & $87 \pm 11$ \\
$12 \mathrm{~h}$ & $114 \pm 17$ & $120 \pm 14$ & $116 \pm 9$ & $101 \pm 9$ \\
$24 \mathrm{~h}$ & $105 \pm 13$ & $104 \pm 12$ & $86 \pm 9$ & $97 \pm 12$ \\
$48 \mathrm{~h}$ & $94 \pm 11$ & $86 \pm 6$ & $99 \pm 12$ & $97 \pm 11$ \\
$72 \mathrm{~h}$ & $96 \pm 9$ & $102 \pm 7$ & $99 \pm 13$ & $91 \pm 8$ \\
\hline
\end{tabular}

Values are means \pm SEM; Fiber number: the number of fibers included in the fiber type-specific immunohistological analyses of satellite cell content 

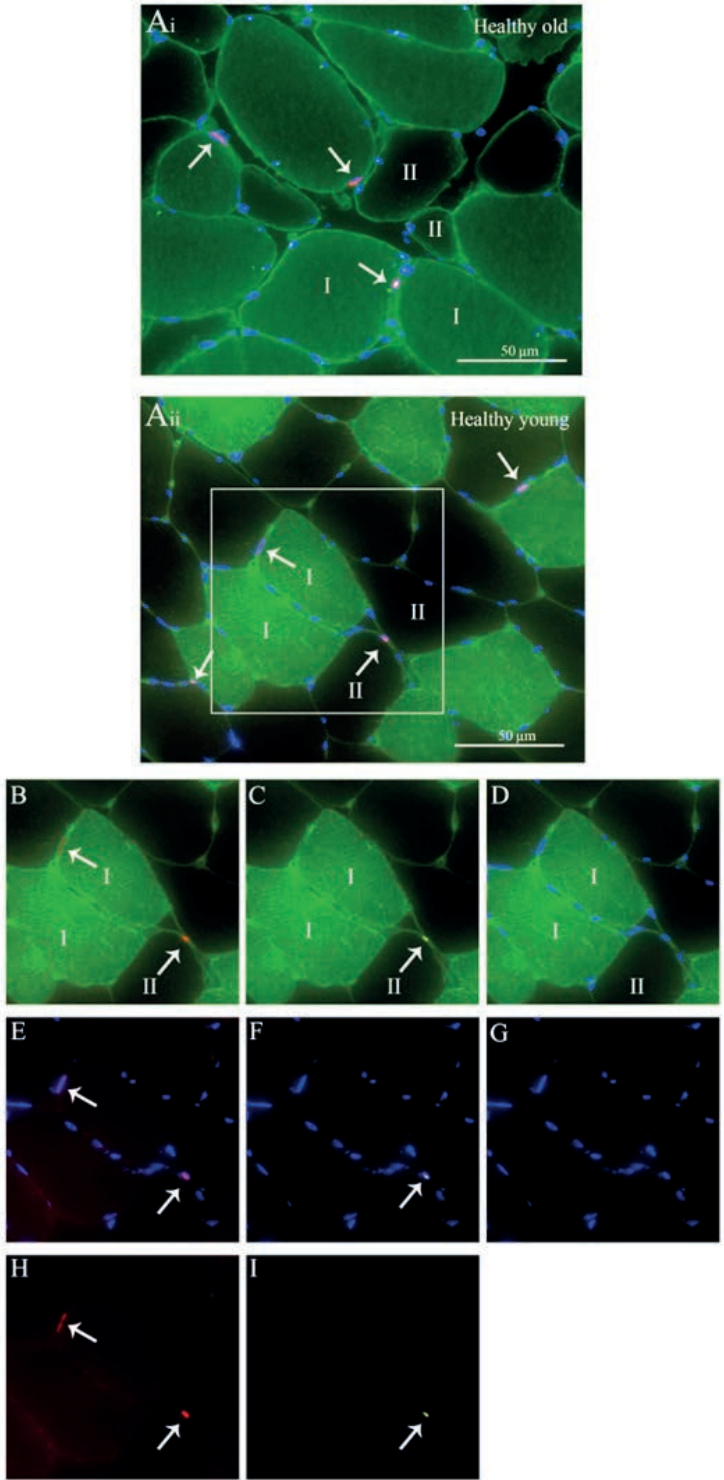

Figure 2 Representation of fiber type-specific analyses of skeletal muscle satellite cell (SC) content and myostatin in both a healthy old ( $\mathrm{Ai}$ ) and young (Aii) man. Ai-ii: $\mathrm{MHCl}$ (green) + laminin (green) + Dapi (blue) + Pax7 (red) + myostatin (yellow) staining. $\mathrm{B}: \mathrm{MHCl}+$ laminin + Pax7. $\mathrm{C}: \mathrm{MHCl}+$ laminin + myostatin. D: $\mathrm{MHCl}+$ laminin + Dapi. E: Dapi + Pax7. F: Dapi + myostatin. G: Dapi only. H: Pax7 only. I: myostatin only. Arrows point at the SCs.

\section{Quantitative rtPCR}

Total RNA was isolated from $10-20 \mathrm{mg}$ of frozen muscle tissue using Trizol $^{\circledR}$ Reagent (Invitrogen), according to the manufacturer's protocol. Total RNA quantification was 
carried out spectrophotometrically at $260 \mathrm{~nm}$ (NanoDrop ND-1000 Spectrophotometer, Thermo Fisher Scientific, USA), and RNA purity was determined as the ratio of readings at $260 / 280 \mathrm{~nm}$. The first-strand complementary DNA (cDNA) was synthesized from 1- $\mu \mathrm{g}$ RNA sample using iScriptTM cDNA synthesis kit (BIO-RAD). Taqman PCR was carried out using 7300 Real Time PCR system (Applied BioSystems, USA) with $2 \mu \mathrm{L}$ of cDNA (diluted five times), Mastermix: Taqman ${ }^{\circledR}$ Gene Expression Mastermix (Applied Biosytems) was added resulting in a total volume of $25 \mu \mathrm{L}$. Taqman primer/probe sets were obtained from Applied Biosystems (Taqman ${ }^{\circledR}$ Gene Expression Assays): myogenin, MyoD, and myostatin; primers are listed in Table 2. Each sample was run in duplicate. The housekeeping gene hydroxymethylbilane synthase (HMBS) was used as an internal control. The thermal cycling conditions used were $2 \mathrm{~min}$ at $50^{\circ} \mathrm{C}, 10 \mathrm{~min}$ at $950 \mathrm{C}$, followed by 40 cycles at $950 \mathrm{C}$ for $15 \mathrm{~s}$ and $600 \mathrm{C}$ for $1 \mathrm{~min}$. Ct values of the target gene were normalized to $\mathrm{Ct}$ values of the internal control HMBS, and final results were calculated according to the $2^{-\Delta \Delta} \mathrm{Ct}$ method. The muscle biopsy attained before the single bout of exercise was used as a reference and given a value of 1 , and fold changes at $12,24,48$, and $72 \mathrm{~h}$ of post-exercise recovery were calculated.

Table 2 qRT-PCR probes

\begin{tabular}{lcc}
\hline Gene Name & Probe number & $\begin{array}{c}\text { NCBI Gene } \\
\text { ID Number }\end{array}$ \\
\hline Myostatin & Hs 00193363 & 2660 \\
MyoD & Hs 00159528 & 4654 \\
Myogenin & Hs 00231167 & 4656 \\
HMBS & Hs 00609297 & 3145 \\
\hline
\end{tabular}

MyoD, myogenic determination factor; HMBS, hydroxymethylbilane synthase

\section{Western blotting}

From each muscle sample frozen for biochemical analyses, 30-40 mg was homogenized in Tris buffer $(50 \mathrm{mM}, 1 \mathrm{mM}$ EDTA, $1 \mathrm{mM}$ EGTA, $0.1 \%$ Nonidet P40, $0.1 \%$ 2mercaptoethanol $\mathrm{pH}$ 7.4) supplemented with the following protease and phosphatase inhibitors: aprotinin $2 \mathrm{mg} / \mathrm{mL}$, leupeptin $2 \mathrm{mg} / \mathrm{mL}$, benzamidine $300 \mathrm{mM}$, and PMSF 100 $\mathrm{mM}$. After homogenization, each muscle extract was centrifuged for $5 \mathrm{~min}$ at 10,000 $\mathrm{g}$ $(4$ ㅇ $)$ and supernatant was used as nuclear fraction. Sample buffer was added to the supernatant to a final concentration of $60 \mathrm{mM}$ Tris, $5 \%$ glycerol,and $20 \mathrm{mg} / \mathrm{mL} \mathrm{SDS}$,

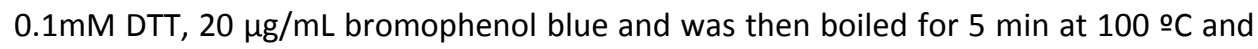
subsequently cooled on ice. Immediately before analyses, the muscle extraction sample was warmed to 50 ㅇ $\mathrm{C}$ and centrifuged for $1 \mathrm{~min}$ at 3,000 g (RT). Total amount of sample loaded on the gel was based on weight (3.125 mg muscle per lane). Protein samples were run on a 4-15\% Criterion Tris- $\mathrm{HCl}$ gel (Biorad Order No. 3450027) for $10 \mathrm{~min}$ at 50 $\mathrm{V}$ (constant voltage) and $1 \mathrm{~h} 40 \mathrm{~min}$ at $120 \mathrm{~V}$ (constant voltage) and transferred onto a polyvinylidene difluoride membrane (PVDF) in $1 \mathrm{~h} 30 \mathrm{~min}$ at constant $500 \mathrm{~mA}$. Specific 
proteins were detected by incubation with specific antibodies in $1 \%$ bovine serum albumin (BSA) in $0.1 \%$ phosphate-buffered saline (PBS)-Tween 20 after blocking in $1 \%$ BSA in 0.1\% PBS-Tween (Sigma Order No. A6003-25G). The antibodies used in this study were anti MyoD (37 KD; rabbit polyclonal IgG, Santa Cruz sc-760), anti Myostatin (50 KD; rabbit polyclonal IgG; Santa Cruz sc-6885-R) and anti $\alpha$-actin (42 KD; mouse monoclonal IgM; Sigma A2172). Following incubation, membranes were washed ( $3 \times 5 \mathrm{~min}$ ) in $0.1 \%$ PBS-Tween 20 and incubated ( $1 \mathrm{~h}$ at RT) with the appropriate secondary antibody, polyclonal rabbit anti-mouse IgG-HRP (Dako, P0161) and polyclonal swine anti-rabbit IgG-HRP (Dako, P0399) dissolved in \% BSA $0.1 \%$ PBS-Tween 20. After a final wash step (3 $\times 5 \mathrm{~min}$ ) in $0.1 \%$ Tween 20-PBS the membranes were incubated with Supersignal West Dura Extended Duration Substrate (Thermo Scientific, No. 340760) for 1 min. Visualization and quantification of the protein bands were enabled by Biorad universal hood II and Chemidoc XRS camera and Quantity One 4.6.5 software, respectively.

\section{Statistics}

All data are expressed as means \pm SEM. An independent samples Student's t test was used to compare differences between groups at baseline. Data were analyzed using a two-way repeated measures ANOVA with group (young vs old) as between-subject factor and time (before exercise (pre-) vs $12,24,48$, or $72 \mathrm{~h}$ post-exercise recovery) and fiber type (type I vs II) as within-subject factors. In the two-way repeated measures ANOVA design, post-exercise time points were compared with baseline values only and Bonferroni corrections were applied to account for multiple comparisons to baseline. Separate analyses (within groups or within fiber type) were performed in case significant interactions and Bonferroni corrections were applied to correct for multiple testing. Statistical significance was set at $P<0.05$. All calculations were performed using SPSS 19.0 (Chicago, IL).

\section{RESULTS}

\section{Subject characteristics}

Characteristics of both groups are presented in Table 3. Muscle strength as assessed by $1-\mathrm{RM}$; both leg press and leg extension were significantly lower in the elderly $(168 \pm 8$ and $84 \pm 3 \mathrm{~kg}$, respectively) compared with that in the young men $(214 \pm 7$ and $137 \pm 4 \mathrm{~kg}$, respectively; $P<0.001)$. In accordance, leg lean mass was significantly lower in the older compared with the young men $(18.4 \pm 0.5$ vs $21.1 \pm 0.4 \mathrm{~kg}$, respectively; $\mathrm{P}<0.001)$.

\section{Muscle fiber cross-sectional area and fiber type distribution}

No significant differences were observed in type I muscle fiber cross-sectional area between groups. In contrast, type II muscle fiber cross-sectional area was significantly smaller in the older compared with that in the young men $\left(5574 \pm 371 \mathrm{vs} 7584 \pm 390 \mu \mathrm{m}^{2}\right.$, 
respectively; $P<0.01)$. Furthermore, in the healthy young men, muscle fiber crosssectional area was significantly greater in type II compared with type I fibers $(P<0.01$; Table 4). In contrast, type II muscle fiber cross-sectional area was significantly smaller than type I muscle fiber cross-sectional in the elderly men $(P<0.01$; Table 4$)$. No differences in fiber type distribution (fiber \% and/or CSA\%) nor in fiber circularity were observed between young and elderly men (Table 4). In addition, no changes were observed in muscle fiber cross-sectional area, fiber type distribution, and/or fiber circularity within the $72 \mathrm{~h}$ of post-exercise recovery (data not shown).

Table 3 Subjects' characteristics

\begin{tabular}{lcc}
\hline & Young & Old \\
\hline Age $(\mathrm{yr})$ & $22 \pm 1$ & $73 \pm 1^{*}$ \\
Height $(\mathrm{m})$ & $1.82 \pm 0.02$ & $1.75 \pm 0.02^{*}$ \\
Weight $(\mathrm{kg})$ & $76 \pm 2$ & $79 \pm 3$ \\
BMI $(\mathrm{kg} / \mathrm{m} 2)$ & $23.0 \pm 0.6$ & $25.7 \pm 0.8^{*}$ \\
Whole body lean mass $(\mathrm{kg})$ & $58.4 \pm 1.2$ & $55.9 \pm 1.9$ \\
Leg lean mass $(\mathrm{kg})$ & $21.1 \pm 0.4$ & $18.4 \pm 0.5^{*}$ \\
Whole body fat $(\%)$ & $15 \pm 2$ & $22 \pm 1^{*}$ \\
1-RM leg press $(\mathrm{kg})$ & $214 \pm 7$ & $168 \pm 8^{*}$ \\
1-RM leg extension $(\mathrm{kg})$ & $137 \pm 4$ & $84 \pm 3^{*}$ \\
\hline
\end{tabular}

Values are means \pm SEM; $n=10$ per group. BMI, body mass index; $1 R M$, one repetition maximum; * significantly different compared with young men.

Table 4 Muscle fiber distribution and fiber area

\begin{tabular}{lccc}
\hline & Fiber type & Young & Old \\
\hline Fiber circularity & I & $0.77 \pm 0.01$ & $0.75 \pm 0.01$ \\
Fiber type distribution (Fiber\%) & II & $0.77 \pm 0.01$ & $0.72 \pm 0.01$ \\
& I & $51 \pm 3$ & $56 \pm 5$ \\
Fiber type distribution (CSA\%) & II & $49 \pm 3$ & $44 \pm 5$ \\
& I & $47 \pm 4$ & $57 \pm 4$ \\
Muscle fiber CSA $\left(\mu \mathrm{m}^{2}\right)$ & II & $53 \pm 4$ & $43 \pm 4$ \\
& I & $6316 \pm 486$ & $6566 \pm 364$ \\
\hline
\end{tabular}

Data represent means \pm SEM. CSA: cross-sectional area. \#: significantly different compared with type I muscle fibers $(P<0.05)$. *: Significantly different compared with young $(P<0.05)$.

\section{Satellite cell content}

At baseline, the number of SCs in the type II muscle fibers was significantly lower in the elderly compared with that in the young men $(0.077 \pm 0.005$ vs $0.102 \pm 0.007$ SCs per muscle fiber, respectively; $P<0.01)$. The number of SC per type I muscle fiber had significantly increased after $12(+14 \pm 5$ and $+10 \pm 7 \%$; $P<0.01), 48(+42 \pm 12$ and $+40 \pm 8 \%$; 
$\mathrm{P}<0.001)$, and $72 \mathrm{~h}(+49 \pm 18$ and $+45 \pm 19 \% ; P<0.001)$ of recovery when compared with pre-exercise values in both the young and the elderly men, respectively (Figure $3 \mathrm{~A}$ ). At $24 \mathrm{~h}$ post-exercise, type I muscle fiber SC content tended to be greater compared to baseline values in both groups (Figure 3A; $P=0.052$ ). Type II muscle fiber SC content was significantly increased at $48(+34 \pm 11 \% P<0.001)$ and $72 \mathrm{~h}(+48 \pm 15 \% ; P<0.001)$ after the single bout of exercise in the healthy young men, with a non-significant increase also observed at $24 \mathrm{~h}(P=0.052)$. In contrast, type II muscle fiber SC content was only increased after $72 \mathrm{~h}$ of post-exercise recovery $(+34 \pm 11 \%)$ in the older men (Figure $3 \mathrm{~B}$; $P<0.001)$. When expressed per millimeter squared, we observed similar changes in SC contents during post-exercise recovery in both the young and older men. The number of SCs per millimeter squared in type I muscle fibers had increased significantly after 24 $(P<0.01), 48(P<0.001)$, and $72 \mathrm{~h}(P<0.001)$ of post-exercise recovery when compared with baseline values in both the young and older men (Table 5). Whereas the number of SCs per millimeter squared in type II muscle fiber was significantly increased at 24 $(P<0.01), 48(P<0.001)$, and $72 \mathrm{~h}(P<0.001)$ after cessation of exercise in the healthy young men, changes in type II muscle fiber SC content in the older men were not observed until after $72 \mathrm{~h}$ of post-exercise recovery (Table 5).

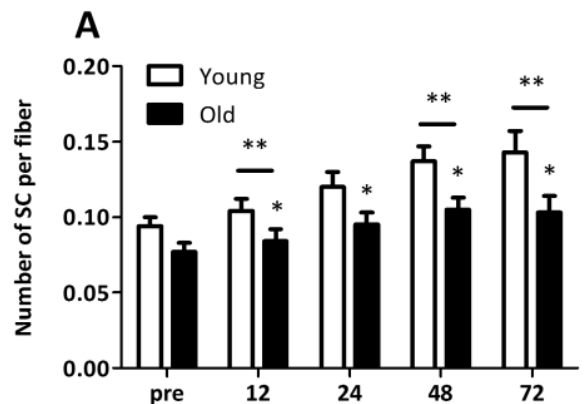

B

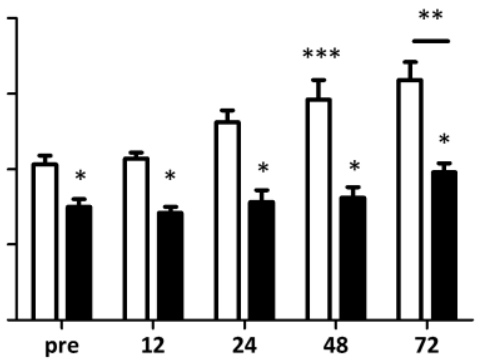

Figure 3 Mean number of satellite cells (SCs) per muscle fiber in both type I (A) and type II (B) muscle fibers before (pre) and $12,24,48$, and $72 \mathrm{~h}$ after a single bout of resistance in young $(\mathrm{n}=10)$ and old $(n=10)$ men. Values represent means $\pm S E M$. *: indicates significant group effect $(P<0.01)$. $* *$ : indicates significant effect of time compared with pre-exercise value $(P<0.01)$. ${ }^{* * *}$ : indicates significant effect of time compared with pre-exercise value in young men only $(P<0.01)$. Bar indicates the effect of time is present in both groups 
Table 5 Type I and II muscle fiber satellite cell content

\begin{tabular}{cccccccc}
\hline & Group & $\begin{array}{c}\text { Fiber } \\
\text { Type }\end{array}$ & Pre & $12 \mathrm{~h}$ & $24 \mathrm{~h}$ & $48 \mathrm{~h}$ & $72 \mathrm{~h}$ \\
\hline $\mathrm{Nr}$ of SC$/ \mathrm{mm}^{2}$ & Young & I & $16.6 \pm 1.7$ & $18.4 \pm 2.9$ & $20.0 \pm 2.7^{*}$ & $22.0 \pm 1.9^{*}$ & $23.4 \pm 3.0^{*}$ \\
& Old & I & $11.6 \pm 1.2$ & $13.1 \pm 1.4$ & $16.1 \pm 1.3^{*}$ & $16.7 \pm 2.0^{*}$ & $16.5 \pm 3.0^{*}$ \\
& Young & II & $14.0 \pm 1.0$ & $13.7 \pm 1.0$ & $17.7 \pm 1.4^{*}$ & $18.5 \pm 1.3^{*}$ & $20.3 \pm 2.0^{*}$ \\
& Old & II & $14.4 \pm 1.9$ & $15.7 \pm 1.5$ & $14.8 \pm 1.3$ & $15.4 \pm 1.3$ & $19.4 \pm 2.0^{*}$ \\
\hline
\end{tabular}

Data represent means \pm SEM. SC: Satellite cell. * Significantly different compared with pre-exercise values.

\section{MyoD+ satellite cells}

At baseline, MyoD was expressed in $25-30 \%$ of all SCs with no significant differences between groups (see Figure 1 for representative image of the immunohistological staining). In response to the single bout of resistance type exercise the number of mixed muscle MyoD+ SCs per fiber was significantly increased at all time points when compared with pre-exercise values (Figure $4 ; P<0.01$ ) in the healthy young men. In contrast, mixed muscle MyoD+ SCs per fiber was increased after $24(P<0.001), 48(P<0.001)$, and $72 \mathrm{~h}(P<0.001)$ of post-exercise recovery in the elderly men. In addition, we observed a significantly greater increase in the number of MyoD+ SCs in the young compared with the elderly men at $48 \mathrm{~h}$ after a single bout of exercise (time $\mathrm{x}$ group interaction, $\mathrm{P}=0.027$; Figure 5).

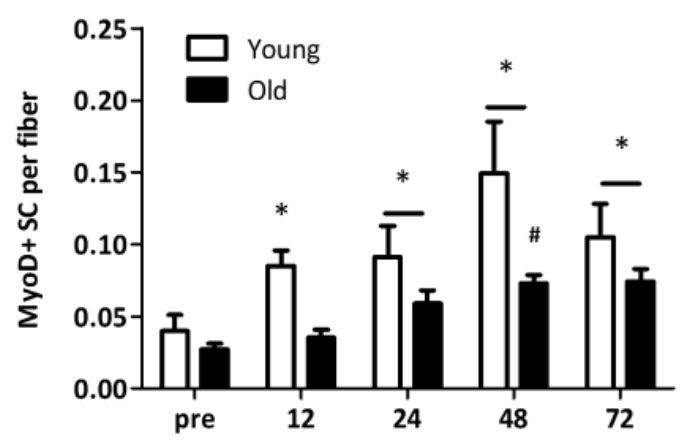

Figure 4 Changes in mixed muscle MyoD+ satellite cells (SC) per muscle fiber before and 12, 24, 48 , and $72 \mathrm{~h}$ after a single bout of resistance type exercise in young $(n=6)$ and old $(n=8)$ men. Values represent means \pm SEM. *: indicates significant effect of time compared with pre-exercise value $(P<0.01)$. \#: indicates significant time $x$ group interaction, increase from pre-exercise value is smaller in old compared with young men $(P<0.01)$. Bar indicates the effect of time is present in both groups.

\section{Myostatin+ satellite cells}

At baseline, myostatin was expressed in $70-80 \%$ of all SCs with no differences between type I and type II muscle fibers (see Figure 2 for representative image of the immunohistological staining). In addition, before exercise the proportion of myostatin+ SCs did not differ between groups. In response to the single bout of resistance type exercise, both groups showed a substantial decline in the percentage of myostatin+ SCs at all 
time points when compared to pre-exercise values (Figure $5 \mathrm{a}, \mathrm{b} ; \mathrm{P}<0.001$ ). However, at $12(P<0.01)$ and $48 \mathrm{~h}(\mathrm{P}<0.01)$ after exercise cessation, the reduction in the percentage of myostatin+ SCs was significantly higher in the young compared with that in the elderly men (Figure 5a,b). Furthermore, both groups showed a larger decrease in the proportion of myostatin+ SCs in type II compared to type I muscle fibers at 12 and $24 \mathrm{~h}$ after the single bout of resistance type exercise.
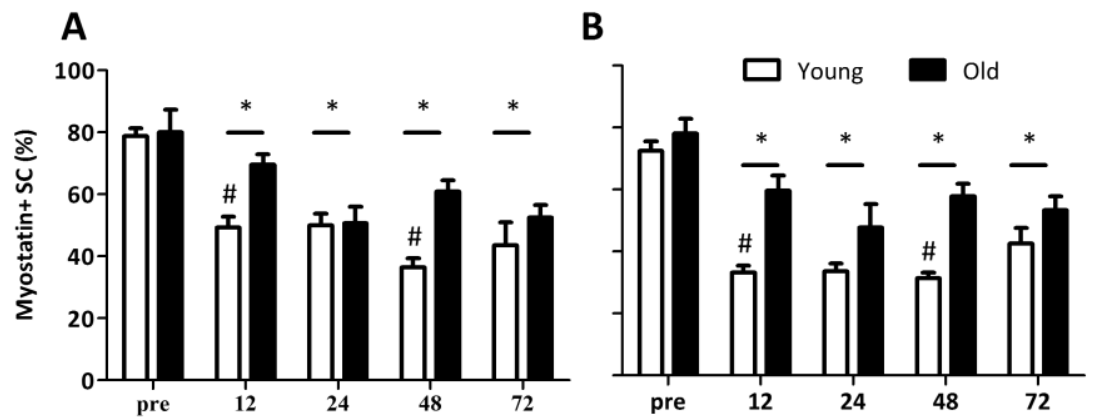

Figure 5 Proportion of myostatin+ satellite cells (SC) in both type I (A) and type II (B) muscle fibers before (pre) and 12, 24, 48, and $72 \mathrm{~h}$ after a single bout of resistance exercise in young $(\mathrm{n}=10)$ and old $(n=10)$ men. Values represent means \pm SEM. *: indicates significant effect of time compared with pre-exercise value $(P<0.01)$. \#: indicates significant time $\mathrm{x}$ group interaction, decrease from pre-exercise value is larger in young compared with old men $(P<0.01)$. Bar indicates the effect of time is present in both groups.

\section{mRNA expression}

MyoD mRNA expression increased significantly at 12 ( \pm 3 and \pm 6 fold, respectively; $P<0.01)$ and $24 \mathrm{~h}( \pm 2$ and \pm 2 fold, respectively; $P=0.03$ ) after the single bout of resistance type exercise in both young and elderly men (Figure 6A). The increase in MyoD mRNA expression over time did not differ between groups. In contrast, myogenin mRNA expression revealed a larger increase in the young $(9.3 \pm 2.3$ fold) compared with the elderly men (3.6 \pm 0.5 fold) at $12 \mathrm{~h}$ after the single exercise bout (Figure 6B; time $\mathrm{x}$ group interaction $P=0.04)$. At $24(P=0.02)$ and $48 \mathrm{~h}(P=0.03)$, myogenin mRNA expression was increased in both groups, with a tendency for a larger increase in the young compared with the elderly men at $48 \mathrm{~h}$ post-exercise recovery (time $\mathrm{x}$ group interaction, $\mathrm{P}=0.056)$. Myostatin mRNA expression was substantially lowered at $24(\mathrm{P}<0.01)$, $48(P<0.001)$, and $72 \mathrm{~h}(P<0.001)$ after the single exercise bout, with no differences between groups (Figure $6 \mathrm{C}$ ). 

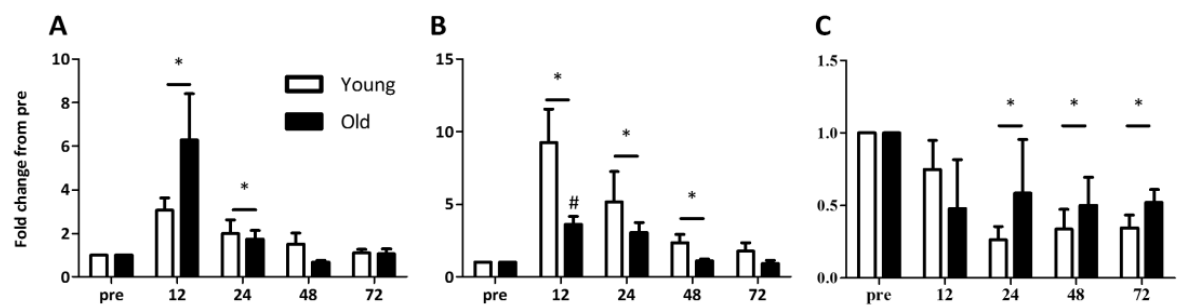

Figure 6 Changes in MyoD (A), myogenin (B), and myostatin (C,) mRNA expression before (pre) and 12, 24, 48, and $72 \mathrm{~h}$ after a single bout of resistance exercise in young $(n=10)$ and old $(n=10)$ men. Fold changes for mRNA expression were calculated using $2{ }^{-{ }^{\Delta C t}}$ method with genes of interest normalized to HMBS. *: indicates significant effect of time compared with pre-exercise value $(P<0.01)$. \#: indicates significant time $x$ group interaction, increase from pre-exercise value is smaller in old compared with young men $(P<0.01)$. Bar indicates the effect of time is present in both groups.

\section{Protein expression}

The increase in MyoD protein expression tended to be greater in the young compared to the elderly in response to the single bout of resistance type exercise (Figure 7A time $x$ group interaction $P=0.092$ ). In contrast, myostatin protein expression was significantly increased after $12 \mathrm{~h}$ of post-exercise recovery in the elderly men, whereas no changes were observed in the young men (Figure $7 B$; time $x$ group interaction $P=0.021$ ). In addition, myostatin protein expression tended to be increased in both groups at $72 \mathrm{~h}$ of post-exercise recovery in both the young and elderly men (Figure 7B; main effect of time $P=0.061$ )
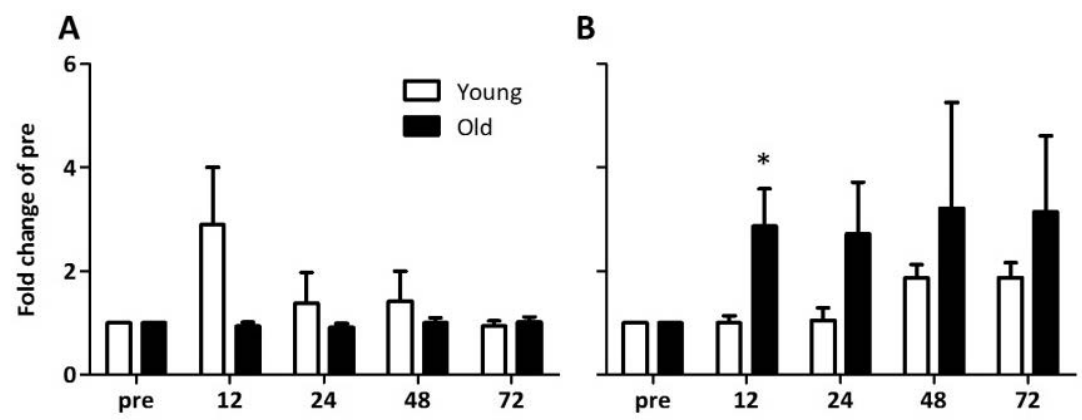

Figure 7 Changes in MyoD (A) and myostatin (B) protein expression 12, 24, 48, and $72 \mathrm{~h}$ after a single bout of resistance type exercise in young $(n=10)$ and old $(n=10)$ men. Values represent means \pm SEM. *: indicates significant effect of time compared with pre-exercise value $(P<0.01)$

\section{Discussion}

In the present study, we show that both type I and type II muscle fiber SC contents increase within $72 \mathrm{~h}$ of recovery from a single bout of resistance type exercise in 
healthy young and elderly men. However, the post-exercise increase in type II muscle fiber SC content is delayed in the elderly when compared with that in the younger men. In addition, we observed an attenuated decline in the number of myostatin+ SCs in the elderly when compared with the young men during recovery from exercise.

Exercise training has been established as an effective interventional strategy to stimulate skeletal muscle growth in both young and elderly people $(7,9,17,23,27,38,51$, 53). The recruitment of SCs has been hypothesized to be imperative for sustained skeletal muscle hypertrophy to occur in response to anabolic stimuli $(1,43-45)$. Although some studies (29) have recently suggested that satellite cells are not necessary for muscle fiber growth in animal models, almost all human studies $(14,40,52,55)$ involving resistance type exercise training show that muscle fiber hypertrophy is accompanied by myonuclear accretion, suggesting a contributing role of satellite cells. In line with previous studies $(3,5,32,34,37,47)$, we show that SC content increases by $49 \pm 18$ and $48 \pm 15 \%$ in the type I and type II muscle fibers during $72 \mathrm{~h}$ of post-exercise recovery in healthy young men (Figure 3). Previous work has failed to show such measurable increases in type II muscle fiber SC content within $48 \mathrm{~h}$ of post-exercise recovery in elderly men (34). In agreement, we observed no changes in type II muscle fiber SC content during the initial $48 \mathrm{~h}$ of post-exercise recovery in our elderly subjects. However, we extend on previous work by showing a significant $34 \pm 11 \%$ increase in type II muscle fiber SC content following $72 \mathrm{~h}$ of post-exercise recovery in the older men (Figure 3B). Interestingly, the increase in type II muscle fiber SC content assessed after $72 \mathrm{~h}$ of postexercise recovery did not significantly differ between the healthy young and elderly men. This is the first study to show that the SC pool in the type II muscle fibers increases in response to a regular bout of resistance type exercise in both young and elderly men, but this response is delayed in older compared with younger men.

To understand the mechanisms responsible for the delayed SC response to exercise in the older population, we determined the expression of MyoD and myogenin at the different time points. It is well established that MyoD acts to promote SC proliferation and transition of cells into differentiation (36), while myogenin is known to drive terminal differentiation (58). In line with previous studies $(33,42,59)$, we show that MyoD and myogenin mRNA expression are substantially upregulated in both young and elderly men during the first 12 to $48 \mathrm{~h}$ of post-exercise recovery. However, at $12 \mathrm{~h}$ postexercise, the increase in myogenin mRNA expression was significantly greater in the young ( $9 \pm 2$ fold) compared with that in the elderly men ( $4 \pm 1$ fold). As mRNA expression is determined in mixed muscle tissue, changes in MyoD and myogenin mRNA expression do not necessarily reflect changes in SC function. Therefore, we also determined MyoD protein expression in the nuclear fraction of the muscle and assessed the number of MyoD+ SCs in response to the single bout of exercise. In the present study we show that MyoD expression tended to increase to a greater extent in the young ( 3 fold increase) compared to the elderly (no change) after $12 \mathrm{~h}$ of post-exercise recovery. In agreement, we observed a significant increase in the number of MyoD+ SCs at $12 \mathrm{~h}$ of 
recovery in the young men, whereas no changes were observed in the elderly men (Figure 4). The number of MyoD+ SCs was significantly higher at 24, 48, and $72 \mathrm{~h}$ after exercise in both the young and older men when compared with baseline values, with a significantly greater increase observed after $48 \mathrm{~h}$ of post-exercise recovery in the young compared to the older men (Figure 5). These results indicate that the SC regulatory pathways are activated to a lesser extent in the old compared with the healthy young during post-exercise recovery. This supports the idea that SC responsiveness is delayed and/or attenuated in healthy elderly men.

Myostatin has been shown to be a strong negative regulator of skeletal muscle growth. In animals, aging is accompanied by an increase in muscle myostatin concentrations (19). In vitro studies have demonstrated that myostatin completely blocks myoblast proliferation and differentiation by the downregulation of $\operatorname{MyoD}(20,49,50)$. Likewise, the rate of SC proliferation in vivo has been reported to be significantly increased in myostatin knockout mice $(30,31,56)$. In contrast, pharmacological blockage of the myostatin/Activin A pathway appears to induce muscle fiber hypertrophy with little to no fusion of satellite cells to the myofiber $(21,30,31,56)$. However, these in vitro and animal studies do not address the potential role of myostatin during muscle fiber growth in more physiological situations, like in response to a single bout of exercise or during adaptation to prolonged resistance type exercise training in (aging) humans. In human skeletal muscle, myostatin protein expression has been reported to be 2-fold higher in healthy elderly men when compared with that in young controls (34). In addition, McKay et al. (2012) have recently shown that myostatin can be located within the $\mathrm{SC}$ in human skeletal muscle tissue and reported that the percentage of myostatin+ SCS declines in skeletal muscle tissue during $48 \mathrm{~h}$ of post-exercise recovery. In line with these previous findings, the present study shows that the percentage of myostatin+ SCs decreases substantially during recovery from exercise in both young and older men in response to a single bout of exercise (Figure 4). However, after 12 and $48 \mathrm{~h}$ of postexercise recovery the decline in the number of myostatin+ SCs was significantly smaller in the elderly when compared with the young. These results are in line with the blunted increase in the number of MyoD+ SCs observed at the same time points. We speculate that during recovery from exercise, healthy elderly men are less able to downregulate myostatin in the SCs compared with their young controls. Such a reduced capacity to downregulate myostatin may be instrumental for the attenuated increase in SC number and, subsequently, a blunted myogenic response to prolonged exercise training.

Besides determining the localization of myostatin within the SC, we also assessed muscle myostatin mRNA and protein expression during post-exercise recovery. In the nuclear fraction of the muscle biopsy samples, myostatin protein expression was significantly upregulated within the first $12 \mathrm{~h}$ after exercise in the older men, whereas it had remained unchanged in the younger men. The upregulation of myostatin protein expression and/or translocation to the SC during post-exercise recovery provides further evidence that a blunted post-exercise myogenic response in the healthy elderly men 
may be mediated by myostatin. In contrast to myostatin protein expression, myostatin mRNA expression decreased significantly during post-exercise recovery, which is supported by many previous reports $(4,15,34)$. Previous studies have shown that there is a Smad-7- dependent negative feedback loop through which increased myostatin protein expression is associated with decreased myostatin mRNA expression $(8,16)$. Such a relation may partly explain the observed discrepancy between myostatin mRNA and protein in the present study. Clearly, more research is warranted to elucidate the precise role of myostatin in skeletal muscle adaptation during post-exercise recovery, and the potential changes with aging herein.

Overall, the results from this study clearly indicate that the SC adaptive response during recovery from a single bout of resistance type exercise is attenuated in the elderly subjects. This attenuated response may play an important role in the proposed reduced capacity of senescent muscle to increase muscle mass and/or fiber cross-sectional area after prolonged resistance type exercise training $(18,39)$. It could be speculated that after a single exercise session, elderly subjects require a more extensive recovery time between exercise bouts to optimize post-exercise reconditioning and, as such, maximize muscle hypertrophy. Studies that assess SC content and activation status at longer time intervals are required to elucidate the time it takes for SC content to peak in both young and elderly people during post-exercise recovery. Alternatively, elderly people may require subsequent bouts of exercise to increase SC content to the same level as healthy young individuals.

We conclude that type I and type II muscle fiber SC content increase during $72 \mathrm{~h}$ of recovery from a single bout of resistance type exercise in both healthy young and elderly men. The increase in type II muscle fiber SC content during post-exercise recovery is delayed in the elderly and is accompanied by a blunted SC activation response. 


\section{References}

1. Adams GR, Caiozzo VJ, Haddad F, and Baldwin KM. Cellular and molecular responses to increased skeletal muscle loading after irradiation. American journal of physiology Cell physiology 283: C11821195, 2002.

2. Bish LT, Morine KJ, Sleeper MM, and Sweeney HL. Myostatin is upregulated following stress in an Erkdependent manner and negatively regulates cardiomyocyte growth in culture and in a mouse model. PLoS One 5: e10230, 2010.

3. Cermak NM, Snijders T, McKay BR, Parise G, Verdijk LB, Tarnopolsky MA, Gibala MJ, et al. Eccentric exercise increases satellite cell content in type II muscle fibers. Med Sci Sports Exerc 45: 230-237, 2013.

4. Costa A, Dalloul H, Hegyesi H, Apor P, Csende Z, Racz L, Vaczi M, et al. Impact of repeated bouts of eccentric exercise on myogenic gene expression. Eur J Appl Physiol 101: 427-436, 2007.

5. Dreyer HC, Blanco CE, Sattler FR, Schroeder ET, and Wiswell RA. Satellite cell numbers in young and older men 24 hours after eccentric exercise. Muscle Nerve 33: 242-253, 2006.

6. Drummond MJ, Miyazaki M, Dreyer HC, Pennings B, Dhanani S, Volpi E, Esser KA, et al. Expression of growth-related genes in young and older human skeletal muscle following an acute stimulation of protein synthesis. J Appl Physiol 106: 1403-1411, 2009.

7. Fiatarone MA, O'Neill EF, Ryan ND, Clements KM, Solares GR, Nelson ME, Roberts SB, et al. Exercise training and nutritional supplementation for physical frailty in very elderly people. The New England journal of medicine 330: 1769-1775, 1994.

8. Forbes D, Jackman M, Bishop A, Thomas M, Kambadur R, and Sharma M. Myostatin auto-regulates its expression by feedback loop through Smad7 dependent mechanism. J Cell Physiol 206: 264-272, 2006.

9. Frontera WR, Meredith CN, O'Reilly KP, Knuttgen HG, and Evans WJ. Strength conditioning in older men: skeletal muscle hypertrophy and improved function. Journal of applied physiology 64: 1038-1044, 1988.

10. Hameed M, Orrell RW, Cobbold M, Goldspink G, and Harridge SD. Expression of IGF-I splice variants in young and old human skeletal muscle after high resistance exercise. J Physiol 547: 247-254, 2003.

11. Harris JA, and Benedict FG. A Biometric study of human basal metabolism. Proc Natl Acad Sci U S A 4: 370-373, 1918.

12. Jespersen JG, Nedergaard A, Andersen LL, Schjerling P, and Andersen JL. Myostatin expression during human muscle hypertrophy and subsequent atrophy: increased myostatin with detraining. Scand J Med Sci Sports 21: 215-223, 2011.

13. Kadi F, Schjerling P, Andersen LL, Charifi N, Madsen JL, Christensen LR, and Andersen JL. The effects of heavy resistance training and detraining on satellite cells in human skeletal muscles. J Physiol 558: 10051012, 2004.

14. Kadi F, and Thornell LE. Concomitant increases in myonuclear and satellite cell content in female trapezius muscle following strength training. Histochem Cell Biol 113: 99-103, 2000.

15. Kim JS, Cross JM, and Bamman MM. Impact of resistance loading on myostatin expression and cell cycle regulation in young and older men and women. Am J Physiol Endocrinol Metab 288: E1110-1119, 2005.

16. Kim JS, Petrella JK, Cross JM, and Bamman MM. Load-mediated downregulation of myostatin mRNA is not sufficient to promote myofiber hypertrophy in humans: a cluster analysis. J Appl Physiol 103: 14881495, 2007.

17. Kosek DJ, Kim JS, Petrella JK, Cross JM, and Bamman MM. Efficacy of 3 days/wk resistance training on myofiber hypertrophy and myogenic mechanisms in young vs. older adults. J Appl Physiol 101: 531-544, 2006.

18. Kosek DJ, Kim JS, Petrella JK, Cross JM, and Bamman MM. Efficacy of 3 days/wk resistance training on myofiber hypertrophy and myogenic mechanisms in young vs. older adults. J Appl Physiol 101: 531-544, 2006.

19. Kovacheva EL, Hikim AP, Shen R, Sinha I, and Sinha-Hikim I. Testosterone supplementation reverses sarcopenia in aging through regulation of myostatin, c-Jun $\mathrm{NH} 2$-terminal kinase, Notch, and Akt signaling pathways. Endocrinology 151: 628-638, 2010. 
20. Langley B, Thomas M, Bishop A, Sharma M, Gilmour S, and Kambadur R. Myostatin inhibits myoblast differentiation by down-regulating MyoD expression. J Biol Chem 277: 49831-49840, 2002.

21. Lee S-J, Huynh T, Lee Y-S, Sebald S, Wilcox-Adelman S, Iwamori N, Lepper C, et al. Role of satellite cells versus myofibers in muscle hypertrophy induced by inhibition of the myostatin/activin signaling pathway. Proceedings of the National Academy of Sciences of the United States of America 109: 60, 2012.

22. Lee SJ. Regulation of muscle mass by myostatin. Annu Rev Cell Dev Biol 20: 61-86, 2004.

23. Leenders M, Verdijk LB, Hoeven LV, Kranenburg JV, Nilwik R, Wodzig WK, Senden JM, et al. Protein supplementation during resistance-type exercise training in the elderly. Medicine and science in sports and exercise 45: 542-552, 2013.

24. Leger B, Derave W, De Bock K, Hespel P, and Russell AP. Human sarcopenia reveals an increase in SOCS-3 and myostatin and a reduced efficiency of Akt phosphorylation. Rejuvenation Res 11: 163-175B, 2008.

25. Lexell J, Taylor CC, and Sjostrom M. What is the cause of the ageing atrophy? Total number, size and proportion of different fiber types studied in whole vastus lateralis muscle from 15- to 83-year-old men. J Neurol Sci 84: 275-294, 1988.

26. Mackey A, Kjaer M, Charifi N, Henriksson J, Bojsen-Moller J, Holm L, and Kadi F. Assessment of satellite cell number and activity status in human skeletal muscle biopsies. Muscle Nerve 40: 455-465, 2009.

27. Mackey AL, Esmarck B, Kadi F, Koskinen SO, Kongsgaard M, Sylvestersen A, Hansen JJ, et al. Enhanced satellite cell proliferation with resistance training in elderly men and women. Scand J Med Sci Sports 17: 34-42, 2007.

28. Mayhew JL, Prinster JL, Ware JS, Zimmer DL, Arabas JR, and Bemben MG. Muscular endurance repetitions to predict bench press strength in men of different training levels. J Sports Med Phys Fitness 35: 108-113, 1995.

29. McCarthy JJ, Mula J, Miyazaki M, Erfani R, Garrison K, Farooqui AB, Srikuea R, et al. Effective fiber hypertrophy in satellite cell-depleted skeletal muscle. Development 138: 3657-3666, 2011.

30. McCroskery S, Thomas M, Maxwell L, Sharma M, and Kambadur R. Myostatin negatively regulates satellite cell activation and self-renewal. J Cell Biol 162: 1135-1147, 2003.

31. McFarlane C, Hui GZ, Amanda WZ, Lau HY, Lokireddy S, Xiaojia G, Mouly V, et al. Human myostatin negatively regulates human myoblast growth and differentiation. Am J Physiol Cell Physiol 301: C195203, 2011.

32. McKay BR, De Lisio M, Johnston AP, O'Reilly CE, Phillips SM, Tarnopolsky MA, and Parise G. Association of interleukin-6 signalling with the muscle stem cell response following muscle-lengthening contractions in humans. PLoS One 4: e6027, 2009.

33. McKay BR, O'Reilly CE, Phillips SM, Tarnopolsky MA, and Parise G. Co-expression of IGF-1 family members with myogenic regulatory factors following acute damaging muscle-lengthening contractions in humans. J Physiol 586: 5549-5560, 2008.

34. McKay BR, Ogborn DI, Bellamy LM, Tarnopolsky MA, and Parise G. Myostatin is associated with agerelated human muscle stem cell dysfunction. FASEB J 26: 2509-2521, 2012.

35. McPherron AC, and Lee SJ. Double muscling in cattle due to mutations in the myostatin gene. Proc Natl Acad Sci U S A 94: 12457-12461, 1997.

36. Megeney LA, Kablar B, Garrett K, Anderson JE, and Rudnicki MA. MyoD is required for myogenic stem cell function in adult skeletal muscle. Genes Dev 10: 1173-1183, 1996.

37. O'Reilly C, McKay B, Phillips S, Tarnopolsky M, and Parise G. Hepatocyte growth factor (HGF) and the satellite cell response following muscle lengthening contractions in humans. Muscle Nerve 38: 14341442, 2008.

38. Petrella JK, Kim JS, Cross JM, Kosek DJ, and Bamman MM. Efficacy of myonuclear addition may explain differential myofiber growth among resistance-trained young and older men and women. Am J Physiol Endocrinol Metab 291: E937-946, 2006.

39. Petrella JK, Kim JS, Cross JM, Kosek DJ, and Bamman MM. Efficacy of myonuclear addition may explain differential myofiber growth among resistance-trained young and older men and women. Am J Physiol Endocrinol Metab 291: E937-946, 2006. 
40. Petrella JK, Kim JS, Mayhew DL, Cross JM, and Bamman MM. Potent myofiber hypertrophy during resistance training in humans is associated with satellite cell-mediated myonuclear addition: a cluster analysis. J Appl Physiol 104: 1736-1742, 2008.

41. Phillips SM, Tipton KD, Aarsland A, Wolf SE, and Wolfe RR. Mixed muscle protein synthesis and breakdown after resistance exercise in humans. Am J Physiol 273: E99-107, 1997.

42. Raue U, Slivka D, Jemiolo B, Hollon C, and Trappe S. Myogenic gene expression at rest and after a bout of resistance exercise in young (18-30 yr) and old (80-89 yr) women. J Appl Physiol 101: 53-59, 2006.

43. Rosenblatt J, and Parry D. Adaptation of rat extensor digitorum longus muscle to gamma irradiation and overload. Pflügers Archiv : European journal of physiology 423: 255-264, 1993.

44. Rosenblatt J, and Parry D. Gamma irradiation prevents compensatory hypertrophy of overloaded mouse extensor digitorum longus muscle. Journal of applied physiology (Bethesda, Md : 1985) 73: 2538-2543, 1992.

45. Rosenblatt J, Yong D, and Parry D. Satellite cell activity is required for hypertrophy of overloaded adult rat muscle. Muscle Nerve 17: 608-613, 1994.

46. Siriett V, Platt L, Salerno MS, Ling N, Kambadur R, and Sharma M. Prolonged absence of myostatin reduces sarcopenia. Journal of cellular physiology 209: 866-873, 2006.

47. Snijders T, Verdijk LB, Beelen M, McKay BR, Parise G, Kadi F, and van Loon LJ. A single bout of exercise activates skeletal muscle satellite cells during subsequent overnight recovery. Exp Physiol 97: 762-773, 2012.

48. Snijders T, Verdijk LB, McKay BR, Smeets JS, van Kranenburg J, Groen BB, Parise G, et al. Acute dietary protein intake restriction is associated with changes in myostatin expression after a single bout of resistance exercise in healthy young men. J Nutr 144: 137-145, 2014.

49. Taylor WE, Bhasin S, Artaza J, Byhower F, Azam M, Willard DH, Jr., Kull FC, Jr., et al. Myostatin inhibits cell proliferation and protein synthesis in $\mathrm{C} 2 \mathrm{C} 12$ muscle cells. American journal of physiology Endocrinology and metabolism 280: E221-228, 2001.

50. Thomas M, Langley B, Berry C, Sharma M, Kirk S, Bass J, and Kambadur R. Myostatin, a negative regulator of muscle growth, functions by inhibiting myoblast proliferation. The Journal of biological chemistry 275: 40235-40243, 2000.

51. Tieland M, Dirks ML, van der Zwaluw N, Verdijk LB, van de Rest O, de Groot LC, and van Loon LJ. Protein supplementation increases muscle mass gain during prolonged resistance-type exercise training in frail elderly people: a randomized, double-blind, placebo-controlled trial. Journal of the American Medical Directors Association 13: 713-719, 2012.

52. Verdijk LB, Gleeson BG, Jonkers RA, Meijer K, Savelberg HH, Dendale P, and van Loon LJ. Skeletal muscle hypertrophy following resistance training is accompanied by a fiber type-specific increase in satellite cell content in elderly men. J Gerontol A Biol Sci Med Sci 64: 332-339, 2009.

53. Verdijk LB, Jonkers RA, Gleeson BG, Beelen M, Meijer K, Savelberg HH, Wodzig WK, et al. Protein supplementation before and after exercise does not further augment skeletal muscle hypertrophy after resistance training in elderly men. Am J Clin Nutr 89: 608-616, 2009.

54. Verdijk LB, Koopman R, Schaart G, Meijer K, Savelberg HH, and van Loon LJ. Satellite cell content is specifically reduced in type II skeletal muscle fibers in the elderly. Am J Physiol Endocrinol Metab 292: E151-157, 2007.

55. Verney J, Kadi F, Charifi N, Feasson L, Saafi MA, Castells J, Piehl-Aulin K, et al. Effects of combined lower body endurance and upper body resistance training on the satellite cell pool in elderly subjects. Muscle Nerve 38: 1147-1154, 2008.

56. Wagner KR, Liu X, Chang X, and Allen RE. Muscle regeneration in the prolonged absence of myostatin. Proceedings of the National Academy of Sciences of the United States of America 102: 2519-2524, 2005.

57. Witard OC, Tieland M, Beelen M, Tipton KD, van Loon $L$, and Koopman R. Resistance exercise increases postprandial muscle protein synthesis in humans. Med Sci Sports Exerc 41: 144-154, 2009.

58. Yablonka-Reuveni Z, and Rivera AJ. Temporal expression of regulatory and structural muscle proteins during myogenesis of satellite cells on isolated adult rat fibers. Dev Biol 164: 588-603, 1994. 
59. Yang Y, Creer A, Jemiolo B, and Trappe S. Time course of myogenic and metabolic gene expression in response to acute exercise in human skeletal muscle. J Appl Physiol 98: 1745-1752, 2005.

60. Yin H, Price F, and Rudnicki M. Satellite cells and the muscle stem cell niche. Physiological reviews 93: 23-67, 2013. 


\title{
Acute dietary protein intake restriction is associated with changes in myostatin expression after a single bout of resistance exercise in healthy young men
}

\author{
Tim Snijders \\ Lex B. Verdijk \\ Bryon R. McKay \\ Joey S.J. Smeets \\ Janneau van Kranenburg \\ Bart B. Groen \\ Gianni Parise \\ Paul Greenhaff \\ Luc J.C. van Loon
}




\section{Abstract}

Introduction: Skeletal muscle satellite cells (SCs) play an important role in the myogenic adaptive response to exercise. It remains to be established whether nutrition plays a role in SC activation in response to exercise. In the present study we assessed whether dietary protein alters the SC response to a single bout of resistance exercise.

Methods: Twenty healthy young ( $21 \pm 2$ years) males were randomly assigned to consume a $4 \mathrm{~d}$ controlled diet that provided either $1.2 \mathrm{~g}$ protein $\cdot \mathrm{kg}$ body weight ${ }^{-1} \cdot \mathrm{d}^{-1}$ (normal protein diet; NPD) or $0.1 \mathrm{~g}$ protein $\cdot \mathrm{kg} \mathrm{BW}^{-1} \cdot \mathrm{d}^{-1}$ (low protein diet; LPD). On the second day of the controlled diet, subjects performed a single bout of resistance exercise. Muscle biopsies from the vastus lateralis were collected prior to and after 12, 24, 48, and $72 \mathrm{~h}$ of post-exercise recovery. SC content and activation status were determined using immunohistochemistry. Protein and mRNA expression were determined using Western blotting and rtPCR.

Results: The number of myostatin+SCs decreased significantly at 12,24 and $48 \mathrm{~h}$ (range: -14 to $-49 \% ; P<0.05$ ) after exercise cessation, with no differences between groups. Whereas the number of myostatin+SCs returned to baseline in the type II fibers on the NPD after $72 \mathrm{~h}$ of recovery, the number remained low on the LPD. At the 48 and $72 \mathrm{~h}$ time point, myostatin protein expression was elevated $(86 \pm 26$ and $88 \pm 29 \%$, respectively) on the NPD $(P<0.05)$, whereas it was reduced at $72 \mathrm{~h}(-36 \pm 12 \%$ compared to baseline) in the LPD group $(P<0.05)$.

Conclusion: This study demonstrates that dietary protein intake does not modulate the post-exercise increase in SC content but modifies myostatin expression in skeletal muscle tissue. 


\section{INTRODUCTION}

Skeletal muscle stem cells, also known as satellite cells (SCs), are thought to play an important role in the myogenic adaptive response to exercise. SCs reside in a niche between the basal lamina and the sarcolemma of their associated muscle fiber. Normally SCs remain in a quiescent state, however, in response to exercise and/or muscle damage SCs can become activated and subsequently proliferate and differentiate. SCS either differentiate to form new myofibers, fuse with existing fibers, or return to a quiescent state, replenishing the resident pool of SC through self-renewal (1). The progression of SCs through the myogenic program is mediated by the expression of different myogenic regulatory factors (MRFs) (e.g. MyoD, Myf-5, Myogenin and Mrf4). The activation, proliferation, and differentiation processes of the SCs represent important regulatory steps that ultimately determine their fate in supporting skeletal muscle fiber adaptation. In addition to the MRFs, myostatin has been identified as a key regulator in the SC response to exercise and/or muscle damage. In animal muscle, reduced myostatin expression has been shown to result in substantial muscle hypertrophy $(2,3)$. More recent work by McKay et al. (4) suggests that in humans, myostatin is a strong negative regulator of the SC myogenic response to an acute bout of resistance exercise. In accordance, as myostatin has been reported to negatively regulate SC activation and self-renewal (5), inhibition of myostatin expression may represent an important myogenic stimulus to allow skeletal muscle hypertrophy in response to prolonged resistance exercise training (6).

Prolonged resistance exercise training has been well-established as an effective interventional strategy to augment skeletal muscle mass and strength (7-9). A single bout of resistance exercise increases muscle protein synthesis as well as breakdown rates, allowing skeletal muscle to recondition (10-12). Ingestion of dietary protein following a single session of resistance exercise further stimulates muscle protein synthesis rate, and reduces muscle protein breakdown, allowing net muscle protein accretion $(10,12)$. In accordance, it has been demonstrated that protein supplementation can augment the increase in skeletal muscle mass in response to prolonged resistance exercise training (13). To turn short-term changes in net muscle protein balance into more long-term muscle fiber hypertrophy, additional myonuclei are prerequisite $(14,15)$. As myonuclei are post-mitotic, skeletal muscle SCs are required to provide new myonuclei during post-exercise recovery. It has been well characterized that protein availability can significantly influence muscle protein synthesis rates following exercise (16-18), which may be translated into long-term benefits (13). It could be speculated that dietary protein can also modulate the SC response during post-exercise recovery, in a feedforward manner as to prepare the muscle's intrinsic potential for long-term adaptation. However, no data exist on the impact of protein intake on the acute SC response after exercise. Therefore, in the present study we assessed SC content and activation status combined with associated myocellular signaling during 3 days of recovery from a single 
bout of resistance exercise while ingesting a normal protein (13 En\%) or low protein ( $<2$ En\%) diet. We hypothesized that the acute SC response to a single bout of exercise would be attenuated by an acute restriction of dietary protein intake.

\section{Methods}

\section{Subjects}

Twenty, healthy male volunteers (age: $21 \pm 2 \mathrm{y}$; height $1.82 \pm 0.01 \mathrm{~m}$; bodyweight: $78 \pm 2$ $\mathrm{kg}$ ) participated in this study (Table 1). All participants were recreationally active, which was defined as participating in non-competitive sporting activities being performed less than 3 times a week. Subjects were informed about the nature and risks of the experimental procedures before their written consent was obtained. The study was approved by the Medical Ethical Committee of the Maastricht University Medical Centre+, and complied with the guidelines set out in the Declaration of Helsinki. Exclusion criteria were defined that would preclude successful participation in the exercise session, which included (silent) cardiac or peripheral vascular disease and orthopedic limitations. After inclusion, all subjects were randomly assigned to consume either a controlled normal protein diet (NPD) or low protein diet (LPD). Body composition (fat and fat-free mass) was determined by Dual Energy X-Ray Absorptiometry scan (DEXA; Hologic Inc., Bedford, USA). Lean mass and percentage body fat were determined on a whole body level and for specific regions (e.g. trunk and legs). In addition, all subjects performed a familiarization trial to become experienced with the research protocol and the equipment. Proper lifting technique was demonstrated and then practiced by the subjects for each of the 2 lower-limb exercises (leg press and leg extension). Subsequently, maximal strength (one-repetition maximum, or 1RM) was estimated by using the multiple repetitions testing procedure during 2 separate visits (19). All strength tests were completed at least 2 weeks before the start of the experimental protocol.

\section{Protocol}

At $08: 00 \mathrm{~h}$, following $24 \mathrm{~h}$ of the controlled diet, subjects reported to the lab after an overnight fast. Following 30 min of supine rest, a muscle biopsy was taken from the $\mathrm{M}$. vastus lateralis. Thereafter, subjects were provided with a standardized breakfast. Next, subjects performed a single bout of resistance exercise, consisting of two different exercises. Subjects performed 6 sets of 10 repetitions at 75\% 1-RM on the horizontal leg press machine (Technogym BV, Rotterdam, The Netherlands) and 6 sets of 10 repetitions at 75\% 1-RM on the leg extension machine (Technogym BV). A resting period of $2 \mathrm{~min}$ between sets was allowed. The entire protocol required approximately $40 \mathrm{~min}$ to complete. All subjects were verbally encouraged during the test to complete the entire protocol. Before and after the exercise session, a 5-10 min warm up / cooling down was performed on a cycle ergometer. At the end of the exercise protocol the subjects rested 
for $3 \mathrm{~h}$ in a supine position. At $12.30 \mathrm{~h}$ subjects received a standardized lunch, after which subjects were provided with a standardized dinner to be consumed at $18.00 \mathrm{~h}$ that evening. On the same day subjects reported back to the laboratory at $20.30 \mathrm{~h}$ for a second muscle biopsy sample collection ( $t=12 \mathrm{~h}$ ). Next, muscle biopsies were taken in an overnight fasted state exactly 24,48 , and $72 \mathrm{~h}$ after the start of the single exercise bout. During the $72 \mathrm{~h}$ post-exercise recovery all subjects adhered to either a standardized normal protein (13 En\% protein) or low protein (<2 En\% protein) diet.

Table 1 Subjects' characteristics

\begin{tabular}{lcc}
\hline & NPD group & LPD group \\
\hline Age $(\mathrm{y})$ & $22 \pm 1$ & $21 \pm 1$ \\
Height $(\mathrm{m})$ & $1.82 \pm 0.02$ & $1.83 \pm 0.03$ \\
Weight $(\mathrm{kg})$ & $75.9 \pm 1.8$ & $79.2 \pm 3.0$ \\
BMI $\left(\mathrm{kg} / \mathrm{m}^{2}\right)$ & $23.0 \pm 0.6$ & $23.7 \pm 0.8$ \\
Whole body lean mass $(\mathrm{kg})$ & $58.4 \pm 17.2$ & $59.7 \pm 18.8$ \\
Leg lean mass $(\mathrm{kg})$ & $21.1 \pm 0.4$ & $22.3 \pm 0.9$ \\
Leg fat $(\%)$ & $15.1 \pm 1.7$ & $16.9 \pm 1.8$ \\
Leg press $(\mathrm{kg})$ & $214 \pm 7$ & $235 \pm 9$ \\
Leg extension $(\mathrm{kg})$ & $137 \pm 4$ & $138 \pm 5$ \\
\hline
\end{tabular}

Values are means \pm SEM; $n=10$ per group, $1 \mathrm{RM}$, subject's one repetition maximum, $\mathrm{BMI}$ : body mass index, LPD: low protein diet group, NPD: normal protein diet group.

\section{Diet control and physical activity}

During the entire $4 \mathrm{~d}$ intervention period all subjects consumed a controlled diet. Subjects were randomly assigned to consume either a normal protein diet (NPD; 13 En\% protein) or a low protein diet (LPD; <2 En\% protein) (Table 2). For each subject the meals were customized and were provided as pre-packages meals, drinks and snacks. Energy intake was based upon the Harris and Benedict equations (20), with a physical activity index of 1.4 (21). All volunteers refrained from any sort of heavy physical exercise $3 \mathrm{~d}$ prior to the first test day until completion of the experiment.

Table 2 Specification of controlled dietary intake

\begin{tabular}{lcc}
\hline & NPD group & LPD group \\
\hline Energy, MJ/d & $11 \pm 0.3$ & $11 \pm 0.6$ \\
Protein, g/d & $88 \pm 2.7$ & $11 \pm 0.4^{*}$ \\
Carbohydrate, g/d & $474 \pm 11$ & $502 \pm 22$ \\
Fat, g/d & $60 \pm 4$ & $56 \pm 6$ \\
\hline
\end{tabular}

Values are means \pm SEM; $n=10$ per group, LPD: low protein diet group, NPD, normal protein diet group. * significantly different compared with NPD $(P<0.0001)$. 


\section{Muscle biopsy}

Muscle biopsies were obtained from the middle region of the vastus lateralis muscle 15 $\mathrm{cm}$ above the patella and approximately $2 \mathrm{~cm}$ away from the fascia by means of the percutaneous needle biopsy technique described by Bergström et al. (22). Muscle biopsies were carefully freed from any visible fat and blood, with one part embedded in Tissue-Tek (Sakura Finetek Europe B.V., Zoeterwoude, Netherlands) and rapidly frozen in liquid nitrogen cooled isopentane, and another part frozen directly in liquid nitrogen, before being stored at $-80 \stackrel{\circ}{\circ}$ for subsequent biochemical and histochemical analysis.

\section{Immunohistochemical analysis}

From all muscle biopsy samples, $5 \mu \mathrm{m}$ thick cross-sections were cut at -20 o $\mathrm{C}$ using a cryostat. Muscle samples collected before and after 12, 24, 48 and $72 \mathrm{~h}$ of post-exercise recovery from each individual subject were mounted together on uncoated glass slides, and air-dried for $3 \mathrm{~h}$ at room temperature before being stored at $-20 \stackrel{\circ}{ } \mathrm{C}$ for subsequent analyses. All muscle cross-sections were stained with antibodies against Pax7 (neat; DSHB); myostatin (near C terminus; 1:100; AB3239; Millipore, Etobicoke, ON, Canada) previously validated to detect the C-terminal (active) myostatin (23, 24); A4.951 [myosin heavy chain type I ( $\mathrm{MHCl}$; slow isoform); neat; DSHB]; laminin (1:1000; L8271, Sigma- Aldrich, Oakville, ON, Canada; and Abcam ab11575, Abcam, Cambridge, MA, USA). Appropriate secondary antibodies were applied: Dylight 488 (1:500, Thermo Scientific, Ontario,ON, Canada), Alexa Fluor 594 (1:500, Invitrogen, Molecular Probes, Carlsbad, CA, USA), biotinylated secondary antibody (1:200; Vector Canada, Burlington, ON, Canada), streptavidin-594 fluorochrome (1:500; Invitrogen, Molecular Probes), Alexa Fluor 488 (1:500), Alexa Fluor 594 (1:500), Alexa Fluor 647 (1:500), Alexa Fluor 350 (1:20). Nuclei were stained with 4,6-diamidino-2-phenylindole (DAPI, $0.238 \mu \mathrm{M}$; Molecular Probes). The immunohistochemical staining procedures were adapted from previously published methods (4). In short, for co-immunofluorescence staining ( $\mathrm{MHCl}$, Laminin, Pax7 and Myostatin) sections were fixed with $4 \%$ paraformaldehyde (Sigma-Aldrich) for 10 min followed by several washes in PBS. Sections were then covered for $60 \mathrm{~min}$ in a blocking solution containing $2 \%$ BSA, 5\% FBS, $0.2 \%$ Triton X-100, $0.1 \%$ sodium azide. Following blocking, sections were incubated in the primary antibody at 4 으 $\mathrm{C}$ overnight. After several washes, sections were then incubated in the appropriate secondary antibodies. Sections were then re-fixed in 4\% PFA to prevent migration of the secondary anti-bodies and re-blocked in $10 \%$ GS in $0.01 \%$ Triton X-10 (Sigma-Aldrich). The sections were then incubated in the second primary antibody, followed by incubation in the appropriate secondary antibody. Sections were then washed with PBS and DAPI was applied for nuclear staining. All stained muscle samples were viewed with the Nikon Eclipse 90i microscope outfitted with a high-resolution QImaging camera for fluorescence detection (Nikon Instruments, Melville, NY, USA), and images were captured and analyzed using the Nikon NIS Elements AR 3.0 software (Nikon Instruments). SC quantification was conducted on $\geq 125$ muscle fibers per subject per 

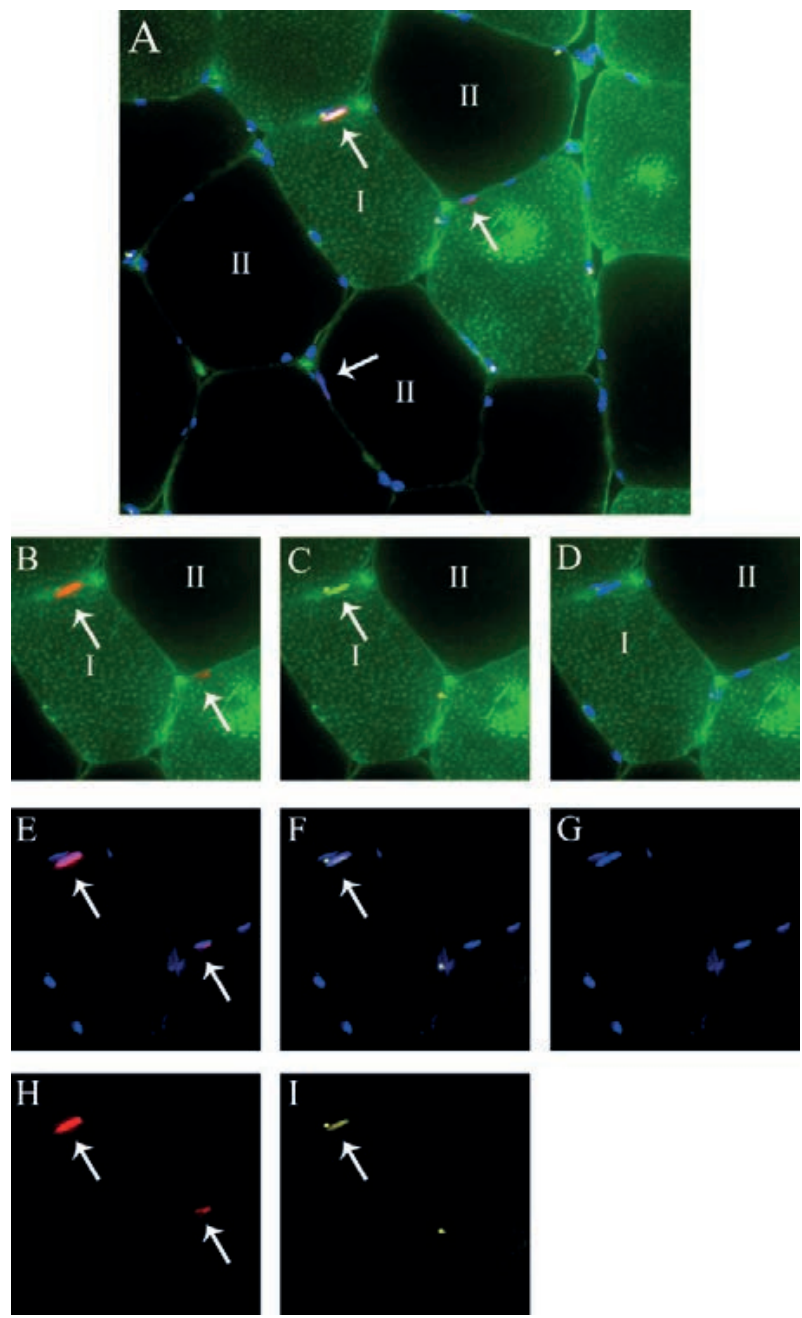

Figure 1 Representation of fiber type specific analyses of skeletal muscle satellite cell (SC) and myostatin. $\mathrm{A}$ : $\mathrm{MHCl}$ (green) + Laminin (green) + Dapi (blue) + Pax7 (red) + myostatin (yellow) staining. B: $\mathrm{MHCl}+$ laminin+Pax7). $\quad \mathrm{C}: \quad \mathrm{MHCl}$ Laminin+myostatin. $\quad \mathrm{D}$ : $\mathrm{MHCl+laminin+Dapi.} \mathrm{E:} \mathrm{Dapi+Pax7.} \mathrm{F:} \mathrm{Dapi+myostatin.} \mathrm{G:} \mathrm{Dapi} \mathrm{only.} \mathrm{H:}$ Pax7 only. I: myostatin only.

time point, and images were obtained with the $\times 40$ objective. SC were determined by identifying DAPI+ Pax7+ cells within the myofiber (laminin). The number of SCs per muscle fiber, the proportion of SCs [number of SCs/(number of SC + number of myonuclei) $x$ 100], and the number of SCs per fiber area (in $\mathrm{mm}^{2}$ ) were calculated for the type I and type II muscle fibers separately. Within each image the number of myonuclei (number of myonuclei - number of SC) per muscle fiber were assessed for the type I and type II muscle fibers. In addition, SC activation was assessed by the presence of myostatin 
staining inside the SC. A DAPI+Pax7+myostatin+ cell within the myofiber was considered a quiescent SC, and a DAPI+Pax7+Myostatin- cell within in the myofiber was considered to be an activated SC. Slides were masked for both group and time point (See Figure 1 for representative images of the staining).

\section{Quantitative rtPCR}

Total RNA was isolated from $10-20 \mathrm{mg}$ of frozen muscle tissue using Trizol $^{\circledR}$ Reagent (Invitrogen), according to the manufacturer's protocol. Total RNA quantification was carried out spectrophotometrically at $260 \mathrm{~nm}$ (NanoDrop ND-1000 Spectrophotometer, Thermo Fisher Scientific, USA), and RNA purity was determined as the ratio of readings at 260/280 $\mathrm{nm}$. The first strand cDNA was synthesized from $1 \mu \mathrm{g}$ RNA sample using iScriptTM cDNA synthesis kit (BIO-RAD). Taqman PCR was carried out using 7300 Real Time PCR system (AppliedBioSystems, USA), with $2 \mu \mathrm{L}$ of cDNA (diluted 5 times), Mastermix: $\operatorname{Taqman}^{\circledR}$ Gene Expresseion Mastermix (AppliedBiosytems), total volume was $25 \mu \mathrm{L}$. Taqman primer/probe sets were obtained from Applied Biosystems (Taqman ${ }^{\circledR}$ Gene Expression Assays): myogenin, MyoD, and myostatin. Each sample was run in duplicate. The housekeeping gene hydroxymethylbilane synthase (HMBS) was used as an internal control. The thermal cycling conditions used were: $2 \mathrm{~min}$ at $50^{\circ} \mathrm{C}, 10 \mathrm{~min}$ at $95^{\circ} \mathrm{C}$, followed by 40 cycles at $95^{\circ} \mathrm{C}$ for $15 \mathrm{~s}$ and $60^{\circ} \mathrm{C}$ for $1 \mathrm{~min}$. Ct values of the target gene were normalized to $\mathrm{Ct}$ values of the internal control $\mathrm{HMBS}$, and final results were calculated according to the $2^{-\Delta \Delta C t}$. The muscle biopsy attained before the single bout of exercise was used as a reference and given a value of 1 , and relative fold changes at 12 , 24,48 and $72 \mathrm{~h}$ of post-exercise recovery were calculated.

\section{Western blotting}

Each muscle sample frozen for biochemical analyses was homogenized in Tris buffer (50mM, 1mM EDTA, 1mM EGTA, 0.1\% Nonidet P40, 0.1\% 2-mercaptoethanol pH 7.4) supplemented with the following protease and phosphatase inhibitors: Aprotinin $2 \mathrm{mg} / \mathrm{mL}$, Leupeptin 2mg/mL, Benzamidine $300 \mathrm{mM}$ and PMSF $100 \mathrm{mM}$. After homogenization, each muscle extract was centrifuged for $5 \mathrm{~min}$ at $10,000 \mathrm{~g}(4 \circ \mathrm{O})$. The pellet was homogenized with nuclear protein isolation buffer (Hepes $20 \mathrm{mM}, 25 \%$ Glycerol, $\mathrm{NaCl} 500 \mathrm{mM}, \mathrm{MgCl} 21.5 \mathrm{mM}$, EDTA $0.2 \mathrm{mM}$, Aprotinin 2mg/mL, Leupeptin 2mg/mL, Benzamidine $300 \mathrm{mM}$ and PMSF $100 \mathrm{mM}, \mathrm{pH}$ 7.9) and centrifuged for $5 \mathrm{~min}$ at 3,000 g (4으). After homogenization, each muscle extract was centrifuged for $5 \mathrm{~min}$ at 10,000 $\mathrm{g}$ (4으) and sample buffer (final concentration: $60 \mathrm{mM}$ Tris, $5 \%$ glycerol, $20 \mathrm{mg} / \mathrm{mL}$ SDS, $0.1 \mathrm{mM}$ DTT, $20 \mu \mathrm{g} / \mathrm{mL}$ bromophenolblue) was added to the supernatant. The supernatant was boiled for $5 \mathrm{~min}$ at 100 degrees and cooled on ice. Supernatant was used as nuclear fraction.

Immediately before analyses, the muscle extraction sample was warmed to 50 으 and centrifuged for $1 \mathrm{~min}$ at 3,000 $\mathrm{g}$ (RT). Total amount of sample loaded on the gel was based on weight (3.125 mg muscle per lane). Protein samples were run on a $4-15 \%$ 
Criterion Tris- $\mathrm{HCl}$ gel (Biorad Order No. 3450027) for $10 \mathrm{~min}$ at $50 \mathrm{~V}$ (constant voltage) and $1 \mathrm{~h} 40 \mathrm{~min}$ at $120 \mathrm{~V}$ (constant voltage) and transferred onto a polyvinylidene difluoride membrane (PVDF) in $1 \mathrm{~h} 30 \mathrm{~min}$ at constant $500 \mathrm{~mA}$. Specific proteins were detected by incubation with specific antibodies in 1\% BSA in $0.1 \%$ PBS-Tween 20 after blocking in 1\% BSA in 0.1\% PBS-tween (Sigma Ordre No. A6003-25G). The antibodies used in this study were anti MyoD (37 KD; rabbit polyclonal IgG, Santa Cruz sc-760), anti Myostatin (50 KD; rabbit polyclonal IgG; Santa Cruz sc-6885-R) and anti $\alpha$-actin (42 KD; mouse monoclonal IgM; Sigma A2172). Following incubation membranes were washed ( $3 \times 5 \mathrm{~min})$ in $0.1 \%$ PBS-Tween 20 and incubated ( $1 \mathrm{~h}$ at RT) with the appropriate secondary antibody, polyclonal rabbit anti-mouse IgG-HRP (Dako, P0161) and polyclonal swine anti-rabbit IgG-HRP (Dako, P0399) dissolved in 1\% BSA 0.1\% PBS-Tween 20. After a final wash step ( $3 \times 5 \mathrm{~min}$ ) in $0.1 \%$ Tween20-PBS the membranes were incubated with Supersignal West Dura Extended Duration Substrate (Thermo Scientific, No. 340760) for 1 min. Visualization and quantification of the protein bands was enabled by Biorad universal hood II and Chemidoc XRS camera and Quantity One 4.6.5 software, respectively.

\section{Statistics}

All data are expressed as means \pm SEM. An independent samples student T-test was used to compare differences between groups at baseline. Furthermore, data were analyzed using a two-way repeated measures ANOVA with group (NPD or LPD) as between subject factor and time (before exercise (pre), and after 12, 24, 48, or $72 \mathrm{~h}$ of postexercise recovery) and fiber type (type I vs II) as within subject factors. In the two-way repeated measures ANOVA design post-exercise time points were compared with baseline values only and Bonferonni corrections were applied to account for multiple comparisons to baseline. In case of significant time $\mathrm{x}$ group or fiber type $\mathrm{x}$ group interaction, additional analyses were performed for NPD and LPD separately by the use of one-way repeated measures ANOVA. In case of a significant time $x$ fiber type interaction, type I and type II muscle fibers were analyzed separately and Bonferroni correction was applied to correct for multiple testing. Levene's test for equality of variance was used; in the case of unequal variance, independent samples student T-test was performed for unequal variances. Statistical significance was set at $P<0.05$. All calculations were performed using SPSS 19.0 (Chicago, IL).

\section{RESULTS}

\section{Subjects' characteristics}

Subjects' characteristics are presented in Table 1. No differences in age, weight, height, BMI, whole body lean mass, leg lean mass, leg fat percentage, 1RM leg press and 1RM leg extension were observed between groups. 


\section{Dietary intake}

No differences were observed in total energy intake between groups (Table 2). Dietary protein intake was significantly lower in the LPD compared with the NPD group $\left(P<0.001\right.$; Table 2). Subjects in the NPD group consumed $1.16 \pm 0.03 \mathrm{~g}$ protein $\cdot \mathrm{kg}^{-1} \mathrm{BW} \cdot \mathrm{d}^{-}$ 1 , whereas subjects in the LPD group consumed $0.14 \pm 0.01 \mathrm{~g}$ protein $\cdot \mathrm{kg}^{-1} \mathrm{BW} \cdot \mathrm{d}^{-1}$ $(P<0.001$; Table 2$)$.
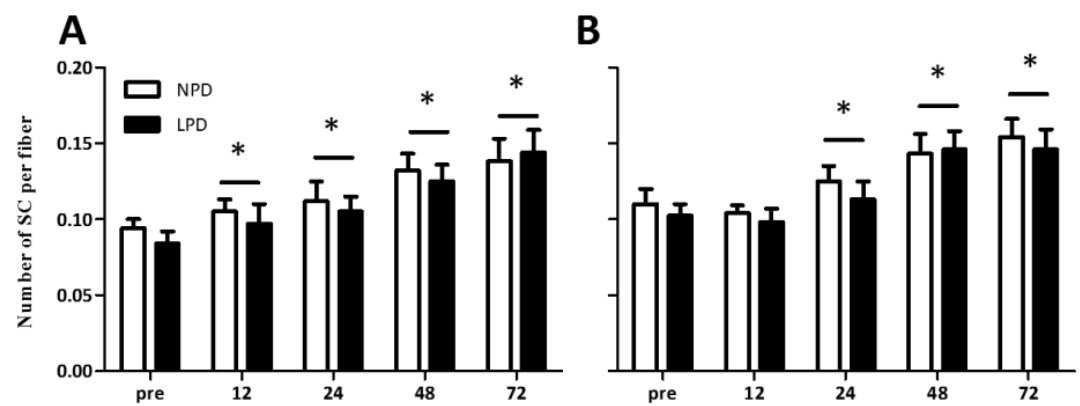

Figure 1 Number of satellite cells (SC) in type I (A) and type II (B) muscle fibers before (pre) and after 12, 24, 48 and $72 \mathrm{~h}$ after a single bout of resistance exercise in healthy young men who consumed a normal or low protein diet for 4 days. Values represent means $\pm S E M . n=10$ per group *: Significantly different compared with pre-exercise values $(P<0.05)$. Bar indicates the effect of time similar for both groups. LPD: low protein diet group; NPD: normal protein diet group.

\section{Muscle fiber type distribution and fiber area}

No group differences in the percentage of type I and type II muscle fibers and/or percentage of muscle area occupied by type I and type II muscle fibers were observed between groups (Table 3).

Table 3 Muscle fiber type composition and muscle fiber size

\begin{tabular}{lccc}
\hline & Fiber type & NPD group & LPD group \\
\hline Fiber type distribution (\%) & I & $52 \pm 4$ & $58 \pm 3$ \\
Fiber type distribution (\%CSA) & II & $48 \pm 4$ & $42 \pm 3$ \\
& I & $47 \pm 4$ & $56 \pm 3$ \\
Muscle fiber CSA (x $\left.1000 \mu \mathrm{m}^{2}\right)$ & II & $53 \pm 4$ & $44 \pm 3$ \\
Myonuclear content $(\mathrm{n} /$ fiber) & I & $6.3 \pm 0.5$ & $6.2 \pm 0.3$ \\
& II & $7.6 \pm 0.4^{*}$ & $6.9 \pm 0.3^{*}$ \\
Myonuclear domain $\left(\mathrm{x} 1000 \mu \mathrm{m}^{2}\right)$ & I & $3.6 \pm 0.3$ & $3.6 \pm 0.3$ \\
& II & $3.5 \pm 0.2$ & $3.4 \pm 0.3$ \\
\hline
\end{tabular}

Data represent means $\pm S E M, n=10$ per group. CSA: fiber cross-sectional area, LPD: low protein diet, NPD: normal protein diet. * Significantly different compared with type I fibers $(P<0.05)$. 
In both groups, muscle fiber cross-sectional area and myonuclear domain size was significantly greater in type II compared with type I fibers (Table $3 ; P<0.05$ ). No changes were observed in fiber type distribution, myonuclear domain size and/or muscle fiber size within $72 \mathrm{~h}$ of post-exercise recovery in either group (data not shown).

\section{Myonuclear and satellite cell content}

No changes were observed in the number of myonuclei per type I and type II muscle fiber in both groups during post-exercise recovery. In contrast, the number of SCs per type I and type II muscle fiber was significantly greater at 24,48 , and $72 \mathrm{~h}$ compared to pre-exercise values in both the LPD and NPD group (Figure $1 ; P<0.05$ ). In addition, in both groups we observed that type I muscle fiber SC content was increased within the first $12 \mathrm{~h}$ of post-exercise recovery when compared with baseline values (Figure 1; $P<0.0001$ ). When SC content was expressed in proportion to the number of myonuclei or per squared millimeter of fiber area, SC content had increased significantly at 24, 48 and $72 \mathrm{~h}$ following exercise in both the NPD and LPD group (Table $4 ; P<0.01$ ).

Table 4 Satellite cell content

\begin{tabular}{lcccccc}
\hline & Group & Pre & $12 \mathrm{~h}$ & $24 \mathrm{~h}$ & $48 \mathrm{~h}$ & $72 \mathrm{~h}$ \\
\hline Type I SC (\%) & NPD & $2.9 \pm 0.5$ & $3.4 \pm 0.4$ & $4.5 \pm 0.5^{*}$ & $4.4 \pm 0.5^{*}$ & $4.5 \pm 0.6^{*}$ \\
& LPD & $2.7 \pm 0.6$ & $2.7 \pm 0.4$ & $3.3 \pm 0.6 *$ & $3.9 \pm 0.4^{*}$ & $4.9 \pm 0.7^{*}$ \\
Type II SC (\%) & NPD & $3.2 \pm 0.6$ & $3.2 \pm 0.4$ & $4.2 \pm 1.0 *$ & $5.0 \pm 0.6 *$ & $5.1 \pm 0.8^{*}$ \\
& LPD & $3.4 \pm 0.3$ & $3.7 \pm 0.4$ & $5.2 \pm 0.8 *$ & $5.0 \pm 0.6 *$ & $4.9 \pm 0.5^{*}$ \\
Type I SC $\left(\mathrm{mm}^{2}\right)$ & NPD & $17.1 \pm 1.9$ & $19.2 \pm 3.3$ & $21.5 \pm 2.6 *$ & $22.9 \pm 2.0 *$ & $25.0 \pm 3.0 *$ \\
& LPD & $14.7 \pm 1.9$ & $15.6 \pm 2.0$ & $17.4 \pm 2.2 *$ & $21.5 \pm 2.0 *$ & $22.8 \pm 2.5^{*}$ \\
Type II SC $\left(\mathrm{mm}^{2}\right)$ & NPD & $13.3 \pm 0.8$ & $14.2 \pm 1.0$ & $18.7 \pm 1.1 *$ & $18.8 \pm 1.5 *$ & $21.3 \pm 2.1 *$ \\
& LPD & $15.5 \pm 1.8$ & $14.9 \pm 1.7$ & $16.4 \pm 1.8 *$ & $21.5 \pm 1.6 *$ & $21.4 \pm 1.5^{*}$ \\
\hline
\end{tabular}

Data represent means $\pm S E M, n=10$ per group. LPD: low protein diet, NPD: normal protein diet, SC: satellite cell.* Significantly different compared with pre-exercise values $(P<0.05)$.

\section{Myostatin+ satellite cells}

Prior to exercise, the proportion of myostatin+ SCs was $76 \pm 3$ and $76 \pm 4 \%$ in the type I and type II muscle fibers. No differences were observed between groups. The number of myostatin+ SCs declined significantly in response to the single bout of resistance exercise in both groups (Figure 2). After 12, 24 and $48 \mathrm{~h}$ of post-exercise recovery both groups showed a similar decline in the number of myostatin+ SCs per muscle fiber (Figure $2 ; P<0.001)$. The decline was significantly greater in the type II $(-49 \pm 5 \%$ in NPD group and $-40 \pm 10 \%$ in LPD group) compared with type I $(-26 \pm 6 \%$ in NPD group and $17 \pm 11 \%$ in LPD group) muscle fibers at 12 and $24 \mathrm{~h}$, respectively $(P<0.05)$. In the NPD group, the number of myostatin+ SCs returned to baseline $72 \mathrm{~h}$ after the single bout of exercise in both type I and II muscle fibers. In contrast, in the LPD group the number of myostatin+ SCs remained significantly depressed in the type II muscle fibers at $72 \mathrm{~h}$ of post-exercise recovery (Figure $4 ; P<0.05$ ). 


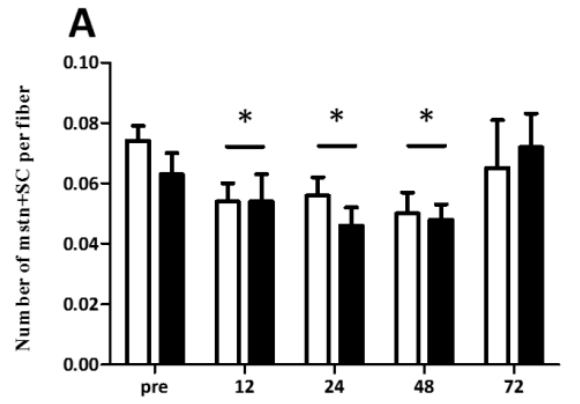

B

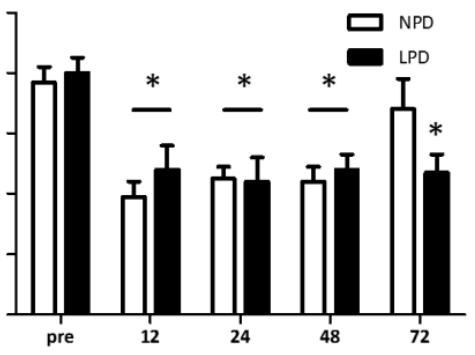

Figure 2 Number of myostatin+ (Mstn) satellite cells (SC) in type I (A) and type II (B) muscle fibers before (pre) and after 12, 24, 48 and $72 \mathrm{~h}$ after a single bout of resistance exercise in healthy young men. Values represent means \pm SEM. $n=10$ per group.*: Significantly different compared with pre-exercise values $(P<0.05)$. Bar indicates the effect of time is similar for both groups. LPD: low protein diet group; NPD: normal protein diet group.

\section{mRNA expression}

MyoD mRNA expression increased significantly at 12 and $24 \mathrm{~h}$ after the single bout of resistance exercise, with no differences between groups (Figure $3 A ; P<0.05$ ). In addition, myogenin mRNA expression increased substantially during the first $12 \mathrm{~h}$ of post exercise recovery $(P<0.05)$. Furthermore, in both groups myogenin mRNA expression remained elevated at 24 and $48 \mathrm{~h}$ after exercise cessation (Figure $3 \mathrm{~B} ; P<0.05$ ). In the NPD group, myostatin mRNA expression was significantly lower at 24 (-76\%), 48 (-64\%), and $72 \mathrm{~h}(-65 \%)$ when compared with pre-exercise expression levels (Figure 3C; $\mathrm{P}<0.05)$. In contrast, the LPD group showed a smaller reduction in myostatin mRNA expression, which was only different from baseline after $48 \mathrm{~h}(-40 \%)$ of post-exercise recovery (Figure $3 C ; P<0.05$ ).

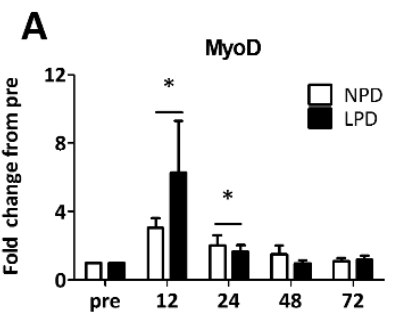

B

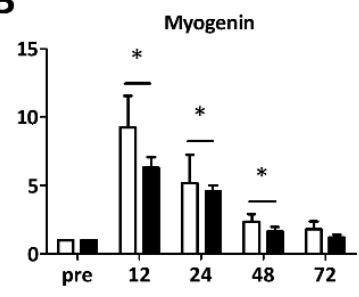

C

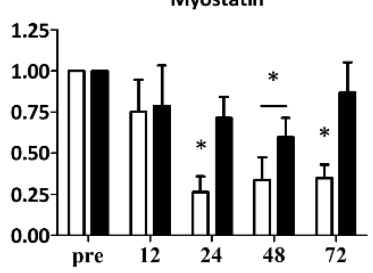

Figure 3 Changes in MyoD, myogenin and myostatin mRNA expression 12, 24, 48 and $72 \mathrm{~h}$ after a single bout of resistance exercise in healthy young men. Values represent means \pm SEM. $n=10$ per group. *: Significantly different compared with pre-exercise values $(P<0.05)$. Bar indicates the effect of time is similar for both groups. LPD: low protein diet group; NPD: normal protein diet group.

\section{Protein expression}

MyoD protein expression was significantly increased at $12 \mathrm{~h}$ after exercise with no differences between groups (Figure $4 A ; P<0.05$ ). In the NPD group, myostatin protein 
expression was significantly elevated after $48(86 \pm 26 \%)$ and $72 \mathrm{~h}(88 \pm 29 \%)$ of postexercise recovery (Figure $4 \mathrm{~B} ; P<0.05$ ). In contrast, myostatin protein expression was significantly reduced $(-36 \pm 12 \%)$ in the LPD group at $72 \mathrm{~h}$ post-exercise compared to baseline (Figure 4B; $P<0.05)$.
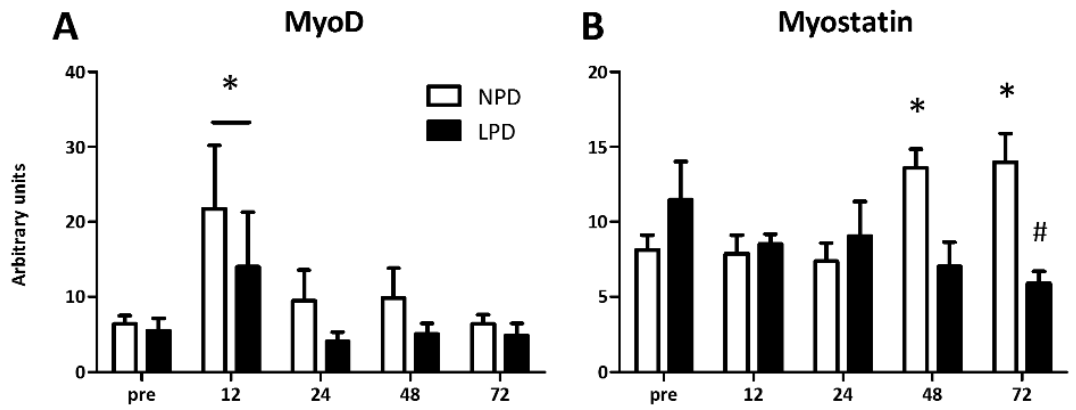

Figure $4 \mathrm{MyoD}$ and myostatin protein expression before (pre) and after 12, 24, 48 and $72 \mathrm{~h}$ after a single bout of resistance exercise in healthy young men. A.U.: Arbitrary Units. Values represent means $\pm S E M . n=10$ per group. *: Significant increase compared with pre-exercise value $(s)(P<0.05)$. \#: Significant decrease compared with pre-exercise value $(P<0.05)$. Bar indicates the effect of time is similar for both groups. LPD: low protein diet group; NPD: normal protein diet group.

\section{DISCUSSION}

In the present study we report that acute dietary protein intake restriction does not affect the increase in SC content in type I and type II muscle fibers after a single bout of resistance exercise. We observed that the number of myostatin+ SCs declined substantially during the first $48 \mathrm{~h}$ of post-exercise recovery, after which they returned to baseline values. However, when dietary protein intake was severely reduced, the number of myostatin+ SCs remained suppressed in the type II muscle fibers. In agreement, skeletal muscle myostatin protein expression was significantly lower during recovery from exercise when dietary protein intake was restricted.

During post-exercise recovery, $\mathrm{SCs}$ are thought to be the sole source for providing new myonuclei, thereby supporting skeletal muscle reconditioning. In accordance, in the present study we show that SC content increases substantially within $72 \mathrm{~h}$ of postexercise recovery (Figure 1). Expansion of the SC pool is consistent with previous work showing similar changes in SC content anywhere between 12 to $192 \mathrm{~h}$ after a single bout of exercise (4, 25-29). A rapid increase in SC content was observed in both type I and type II muscle fibers during post exercise recovery (Figure 1). Similar changes over time were observed when the SC pool size in both type I and type II muscle fibers were expressed relative to the number of myonuclei and/or per millimeter squared (Table 4). Interestingly, type I muscle fiber SC expansion occurred as early as $12 \mathrm{~h}$ into postexercise recovery, whereas it took at least $24 \mathrm{~h}$ to observe a detectable expansion in 
type II muscle fiber SC content. This study confirms that changes in SC content in response to a single bout of exercise are fiber type specific $(4,28,30,31)$. This emphasizes the importance of fiber type specific assessment of SC content and/or activation status in human skeletal muscle.

During post-exercise recovery, dietary protein intake is essential to support the increase in myofibrillar muscle protein synthesis, thereby allowing net muscle protein accretion $(10,12,18)$. However, for more long-term muscle adaptation, SCs are required to provide additional myonuclei to allow muscle fiber hypertrophy. Whether dietary protein intake is prerequisite to allow a proper SC response during recovery from a single bout of resistance exercise has not yet been investigated. We hypothesized that dietary protein intake and subsequent precursor availability drives the SC response to exercise in a feed forward signaling manner. Therefore, we compared the post-exercise change in SC content between subjects consuming $1.2 \mathrm{~g}$ protein $\cdot \mathrm{kg} \mathrm{BW}^{-}$ ${ }^{1} \cdot d^{-1}$ (13 En\% protein) and subjects who restricted their dietary protein intake to less than $0.1 \mathrm{~g}$ protein $\cdot \mathrm{kg} \mathrm{BW}^{-1} \cdot \mathrm{d}^{-1}$ (<2 En\% protein). In healthy young men, dietary protein intake typically ranges between $1.1-1.3 \mathrm{~g}$ protein $\cdot \mathrm{kg} \mathrm{BW}^{-1} \cdot \mathrm{d}^{-1}(7,32-34)$. This is considerably more than the $0.656 \mathrm{~g}$ protein $\cdot \mathrm{kg} \mathrm{BW}^{-1} \cdot \mathrm{d}^{-1}$ that is considered to be the minimum amount of dietary protein required to sustain skeletal muscle mass (35). Though the protein intake restriction in the LPD intervention group is severe and should not be translated to a normal physiological situation, it does provide a first insight in the potential importance of protein intake on the post-exercise SC response. To assess the impact of such an acute reduction in protein intake per se on the post-exercise SC response, all subjects consumed the diet during the 4-day intervention period, starting 24 $\mathrm{h}$ prior to exercise. The current study shows that an acute reduction in dietary protein intake does not affect the increase in muscle fiber SC content with an overall $64 \pm 19$ and $52 \pm 23 \%$ increase in SC content during $72 \mathrm{~h}$ of recovery in the type I and II fibers, respectively, with no differences between groups (Figure 1). These data are the first to show that the SC response to exercise is essentially dissociated from dietary protein intake and is likely evolutionary conserved.

The process of SC activation, proliferation, and differentiation following exercise requires the orchestration of a group of transcription factors collectively referred to as the myogenic regulatory factors (1). It has been well established that MyoD acts to promote SC proliferation and transition of cells into differentiation (36), while myogenin is known to drive terminal differentiation (37). In human skeletal muscle, MyoD and myogenin expression have been reported to increase considerably during the first few hours/days after a single bout of exercise. Consistent with previous work (38-41), we report that MyoD mRNA and protein expression increased following a single bout of resistance exercise (Figure $3 \mathrm{~A}$ and $4 \mathrm{~A}$ ). In addition, we observed a substantial increase in myogenin mRNA expression (Figure 3B), with the peak value observed at $12 \mathrm{~h}$ after exercise cessation. However, it is important to note that the $12 \mathrm{~h}$ post-exercise muscle biopsy sample was taken in the evening (20:30 h) in a post-prandial state, whereas all 
other muscle biopsy samples were taken in the morning after an overnight fast. As such, we cannot exclude a potential effect of the post-prandial vs fasting state on the changes observed at the $12 \mathrm{~h}$ time point. Nonetheless, no significant differences were observed between the NPD and LPD group in the increase in MyoD and myogenin expression during post-exercise recovery. The exercise induced upregulation of MyoD and myogenin allows the SCs to become activated and to progress through the cell cycle thereby proliferating to increase the SC pool size, supporting muscle reconditioning. However, we observed no significant changes in type I and type II muscle fiber myonuclear content, suggesting that SCs have not yet differentiated to a detectable level within the $72 \mathrm{~h}$ of post-exercise recovery in both groups.

Besides the important role of MRFs in determining SC fate, myostatin has been reported to be a strong negative regulator of skeletal muscle growth in both animal $(3,42,43)$ and human models (44). Subsequently, myostatin has been hypothesized to act as a negative regulator of SC activation (5). In support, myostatin has been shown to be highly expressed in quiescent SCS and is significantly down-regulated during SC activation (45). Furthermore, myostatin has been shown to completely block myoblast proliferation in C2C12 cells $(46,47)$. However, previous in vivo animal work on the proposed role of myostatin in SC function has yielded many discrepant findings. Whereas some studies indicate that myostatin acts as a negative regulator of SC activation $(5,48,49)$, others have not been unable to confirm these findings (50-52). The potential role of myostatin in SC activation during a more complex physiological setting such as postexercise recovery remains largely unknown. Only one previous study co-localized, via immunohistochemistry, myostatin within the SCs before and after performing a single bout of resistance exercise (4). This study by McKay et al. (4) demonstrated that the percentage of myostatin+ SCs in human skeletal muscle decreases within the first $48 \mathrm{~h}$ after exercise. In addition, they showed that the post-exercise decline in the number of myostatin+ SCs was accompanied by a concomitant increase in the percentage of My$\mathrm{oD}+\mathrm{SCS}$ and number of SCs in the S-phase of the cell cycle (4), indicative of an increase in SC activation. We extend on these data (4) by assessing the number of myostatin+ SCs and skeletal muscle myostatin expression for up to $72 \mathrm{~h}$ into post-exercise recovery. Our data show that after the initial decline in the number of myostatin+ SCs within the first $48 \mathrm{~h}$ of post-exercise recovery, the number of myostatin+ SCs increases and returns to baseline levels after $72 \mathrm{~h}$ (Figure 2A-B). The return of the number of myostatin+ SCs towards baseline levels suggests a return of the SC to quiescence by $72 \mathrm{~h}$ (4, $5)$. In accordance, myostatin protein expression was shown to be increased at 48 and $72 \mathrm{~h}(86 \pm 26$ and $88 \pm 29 \%$, respectively) compared to pre-exercise values. In contrast, in the present study we also observed that myostatin mRNA expression was downregulated at 24,48 and $72 \mathrm{~h}$ after performing a single bout of resistance exercise. The apparent disconnect between the changes in myostatin expression and the number of myostatin + SCs is explained by the fact that we use Western blotting and real time PCR analyses to assess myostatin protein and mRNA expression in mixed muscle tissue, 
respectively. In contrast, using immunohistochemistry we assess the co-localization of myostatin within the SCs. As such, it is not surprising that the timing and/or direction of changes in myostatin expression and the number of myostatin+ SC do not necessarily follow the same direction. Moreover, even myostatin mRNA and protein expression levels seem discongruent. It has previously been suggested that a smad-7 dependent negative feedback loop exists through which increased myostatin protein expression is associated with decreased myostatin mRNA expression $(53,54)$. However, such a relation cannot fully explain the observed discrepancy between myostatin mRNA and protein in the present study, especially at the $24 \mathrm{~h}$ time point. Clearly, though the exercise induced decrease in myostatin mRNA expression is in line with previous reports $(4,38$, $41,54-56)$ more research is warranted to elucidate the intricate myostatin signaling during post-exercise recovery in human skeletal muscle, and more specifically the expression or translocation of myostatin out of the SC.

It has previously been hypothesized that myostatin expression is also regulated by nutritional intake. However, results from various animal studies on the impact of different nutritional protocols on myostatin expression yield conflicting results. Whereas some do observe changes in myostatin expression in response to changes in nutrient intake (57-59), others do not $(60,61)$. This discrepancy can most likely be attributed to the different study designs, type of nutritional protocols used, and/or studied species. In human skeletal muscle, it has been shown that muscle myostatin mRNA expression is affected by dietary protein provision immediately before and after a single bout of resistance exercise $(33,55)$. The present study is the first to assess whether dietary protein intake alters myostatin expression on multiple levels (in SCs, mRNA and protein expression) in muscle biopsy samples taken at regular time points after a single bout of resistance exercise. At baseline, no significant differences were observed in the number of myostatin+ SC and/or protein expression between groups. In contrast to the NPD group, we show that the number of myostatin+ SCs remained substantially reduced in the type II muscle fibers in the LPD group throughout the entire recovery period (Figure $2 B$ ). In addition, whereas in the NPD group myostatin protein expression increased significantly at 48 and $72 \mathrm{~h}$ of post-exercise recovery, muscle myostatin protein expression remained low in the LPD group (Figure 4B). These differences between groups are likely due to differences in protein intake per se, but may also reflect a response to the acute change in dietary protein intake in the LPD group. Regardless though, the results seem to indicate that under conditions of insufficient protein intake SC activation is maintained over a prolonged period of time during post-exercise recovery. Beside SC activation, myostatin has also been suggested to modulate post-exercise muscle synthesis, e.g. through inhibiting mTOR induced protein synthesis $(62,63)$. The muscle protein synthetic response has been reported to be transient and can be increased up to $48 \mathrm{~h}$ after a single bout of exercise (64). In agreement, we show an increase in myostatin protein expression at 48 and $72 \mathrm{~h}$ of post-exercise recovery, which may indicate that stimulation of muscle protein synthesis following exercise has worn off. In con- 
trast, when insufficient protein is ingested we observed a significant decline in myostatin protein expression after $72 \mathrm{~h}$ of exercise cessation. We speculate that the altered myostatin response in the LPD group may represent a compensatory attempt to allow muscle reconditioning to occur when ample dietary protein derived amino acids become available.

Although it remains to be established through which molecular pathways the proposed feedback coupling between the post-exercise SC signaling response and food availability is regulated, the present findings provide further evidence that post-exercise myostatin expression can be modulated by dietary protein intake. This opens up a wide range of new research questions in which we need to address how physical activity and nutrition interact to allow proper muscle reconditioning. Insight in this intricate interaction will be of key importance to support skeletal muscle mass maintenance and muscle adaptation in both health and disease.

We conclude that SC content and activation status change in a time- and muscle fiber type dependent manner during $72 \mathrm{~h}$ of post-exercise recovery from a single bout of resistance exercise. In addition, the post exercise skeletal muscle adaptive response is changed by the availability of dietary protein, as evidenced by an extended disinhibition of myostatin expression during post-exercise recovery when dietary protein intake is restricted. 


\section{REFERENCES}

1. Hawke TJ, Garry DJ. Myogenic satellite cells: physiology to molecular biology. J Appl Physiol. 2001;91:534-51.

2. McPherron AC, Lee SJ. Suppression of body fat accumulation in myostatin-deficient mice. J Clin Invest. 2002;109:595-601.

3. McPherron AC, Lee SJ. Double muscling in cattle due to mutations in the myostatin gene. Proc Natl Acad Sci U S A. 1997;94:12457-61.

4. McKay BR, Ogborn DI, Bellamy LM, Tarnopolsky MA, Parise G. Myostatin is associated with age-related human muscle stem cell dysfunction. FASEB J. 2012;26:2509-21.

5. McCroskery S, Thomas M, Maxwell L, Sharma M, Kambadur R. Myostatin negatively regulates satellite cell activation and self-renewal. J Cell Biol. 2003;162:1135-47.

6. Huang Z, Chen X, Chen D. Myostatin: a novel insight into its role in metabolism, signal pathways, and expression regulation. Cell Signal. 2011;23:1441-6.

7. Hartman JW, Tang JE, Wilkinson SB, Tarnopolsky MA, Lawrence RL, Fullerton AV, Phillips SM. Consumption of fat-free fluid milk after resistance exercise promotes greater lean mass accretion than does consumption of soy or carbohydrate in young, novice, male weightlifters. Am J Clin Nutr. 2007;86:373-81.

8. Olsen S, Aagaard P, Kadi F, Tufekovic G, Verney J, Olesen JL, Suetta C, Kjaer M. Creatine supplementation augments the increase in satellite cell and myonuclei number in human skeletal muscle induced by strength training. J Physiol. 2006;573:525-34.

9. Willoughby DS, Stout JR, Wilborn CD. Effects of resistance training and protein plus amino acid supplementation on muscle anabolism, mass, and strength. Amino Acids. 2007;32:467-77.

10. Biolo G, Maggi SP, Williams BD, Tipton KD, Wolfe RR. Increased rates of muscle protein turnover and amino acid transport after resistance exercise in humans. Am J Physiol. 1995;268:E514-20.

11. Chesley A, MacDougall JD, Tarnopolsky MA, Atkinson SA, Smith K. Changes in human muscle protein synthesis after resistance exercise. J Appl Physiol. 1992;73:1383-8.

12. Phillips SM, Tipton KD, Aarsland A, Wolf SE, Wolfe RR. Mixed muscle protein synthesis and breakdown after resistance exercise in humans. Am J Physiol. 1997;273:E99-107.

13. Cermak NM, Res PT, de Groot LC, Saris WH, van Loon LJ. Protein supplementation augments the adaptive response of skeletal muscle to resistance-type exercise training: a meta-analysis. Am J Clin Nutr. 2012; 96:1454-64.

14. Rosenblatt JD, Parry DJ. Gamma irradiation prevents compensatory hypertrophy of overloaded mouse extensor digitorum longus muscle. J. Appl Physiol. 1992;73:2538-43.

15. Rosenblatt JD, Yong D, Parry DJ. Satellite cell activity is required for hypertrophy of overloaded adult rat muscle. Muscle \& nerve. 1994;17:608-13.

16. Koopman R, Wagenmakers AJ, Manders RJ, Zorenc AH, Senden JM, Gorselink M, Keizer HA, van Loon LJ. Combined ingestion of protein and free leucine with carbohydrate increases postexercise muscle protein synthesis in vivo in male subjects. Am J Physiol Endocrinol Metab. 2005;288:E645-53.

17. Koopman R, Verdijk LB, Manders RJF, Gijsen AP, Gorselink M, Pijpers E, Wagenmakers AJM, van Loon LJC. Co-ingestion of protein and leucine stimulates muscle protein synthesis rates to the same extent in young and elderly lean men. Am J Clin Nutr. 2006;84:623-32.

18. Tipton KD, Ferrando AA, Phillips SM, Doyle D, Jr., Wolfe RR. Postexercise net protein synthesis in human muscle from orally administered amino acids. Am J Physiol. 1999;276:E628-34.

19. Mayhew JL, Prinster JL, Ware JS, Zimmer DL, Arabas JR, Bemben MG. Muscular endurance repetitions to predict bench press strength in men of different training levels. J Sports Med Phys Fitness. 1995;35:10813.

20. Harris JA, Benedict FG. A Biometric Study of Human Basal Metabolism. Proc Natl Acad Sci U S A. 1918;4:370-3.

21. Human energy requirements. FAO Food and Nutrition Technical Report Series. 2004;1:1-96. 
22. Bergstrom J. Percutaneous needle biopsy of skeletal muscle in physiological and clinical research. Scand J Clin Lab Invest. 1975;35:609-16.

23. Bish LT, Morine KJ, Sleeper MM, Sweeney HL. Myostatin is upregulated following stress in an Erkdependent manner and negatively regulates cardiomyocyte growth in culture and in a mouse model. PLoS One. 2010;5:e10230.

24. Jespersen JG, Nedergaard A, Andersen LL, Schjerling P, Andersen JL. Myostatin expression during human muscle hypertrophy and subsequent atrophy: increased myostatin with detraining. Scand J Med Sci Sports. 2011;21:215-23.

25. Dreyer HC, Blanco CE, Sattler FR, Schroeder ET, Wiswell RA. Satellite cell numbers in young and older men 24 hours after eccentric exercise. Muscle Nerve. 2006;33:242-53.

26. McKay BR, De Lisio M, Johnston AP, O'Reilly CE, Phillips SM, Tarnopolsky MA, Parise G. Association of interleukin-6 signalling with the muscle stem cell response following muscle-lengthening contractions in humans. PLoS One. 2009;4:e6027.

27. O'Reilly C, McKay B, Phillips S, Tarnopolsky M, Parise G. Hepatocyte growth factor (HGF) and the satellite cell response following muscle lengthening contractions in humans. Muscle Nerve. 2008;38:1434-42.

28. Snijders T, Verdijk LB, Beelen M, McKay BR, Parise G, Kadi F, van Loon LJ. A single bout of exercise activates skeletal muscle satellite cells during subsequent overnight recovery. Exp Physiol. 2012;97:76273.

29. Crameri RM, Langberg H, Magnusson P, Jensen CH, Schroder HD, Olesen JL, Suetta C, Teisner B, Kjaer M. Changes in satellite cells in human skeletal muscle after a single bout of high intensity exercise. J Physiol. 2004;558:333-40.

30. Verdijk LB, Gleeson BG, Jonkers RA, Meijer K, Savelberg HH, Dendale P, van Loon LJ. Skeletal muscle hypertrophy following resistance training is accompanied by a fiber type-specific increase in satellite cell content in elderly men. J Gerontol A Biol Sci Med Sci. 2009;64:332-9.

31. Verney J, Kadi F, Charifi N, Feasson L, Saafi MA, Castells J, Piehl-Aulin K, Denis C. Effects of combined lower body endurance and upper body resistance training on the satellite cell pool in elderly subjects. Muscle Nerve. 2008;38:1147-54.

32. Andersen L, Tufekovic G, Zebis M, Crameri R, Verlaan G, Kjaer M, Suetta C, Magnusson P, Aagaard P. The effect of resistance training combined with timed ingestion of protein on muscle fiber size and muscle strength. Metabolism. 2005;54:151-6.

33. Hulmi J, Kovanen V, Selänne H, Kraemer W, Häkkinen K, Mero A. Acute and long-term effects of resistance exercise with or without protein ingestion on muscle hypertrophy and gene expression. Amino Acids. 2009;37:297-308.

34. Vieillevoye S, Poortmans J, Duchateau J, Carpentier A. Effects of a combined essential amino acids/carbohydrate supplementation on muscle mass, architecture and maximal strength following heavy-load training. Eur J Appl Physiol. 2010;110:479-88.

35. Protein and amino acid requirements in human nutrition. World Health Organ Tech Rep Ser. 2007:1-265, back cover.

36. Megeney LA, Kablar B, Garrett K, Anderson JE, Rudnicki MA. MyoD is required for myogenic stem cell function in adult skeletal muscle. Genes Dev. 1996;10:1173-83.

37. Yablonka-Reuveni Z, Rivera AJ. Temporal expression of regulatory and structural muscle proteins during myogenesis of satellite cells on isolated adult rat fibers. Dev Biol. 1994;164:588-603.

38. Raue U, Slivka D, Jemiolo B, Hollon C, Trappe S. Myogenic gene expression at rest and after a bout of resistance exercise in young (18-30 yr) and old (80-89 yr) women. J Appl Physiol. 2006;101:53-9.

39. McKay BR, O'Reilly CE, Phillips SM, Tarnopolsky MA, Parise G. Co-expression of IGF-1 family members with myogenic regulatory factors following acute damaging muscle-lengthening contractions in humans. J Physiol. 2008;586:5549-60.

40. Kosek DJ, Kim JS, Petrella JK, Cross JM, Bamman MM. Efficacy of 3 days/wk resistance training on myofiber hypertrophy and myogenic mechanisms in young vs. older adults. J Appl Physiol. 2006;101:531-44. 
41. Costa A, Dalloul H, Hegyesi H, Apor P, Csende Z, Racz L, Vaczi M, Tihanyi J. Impact of repeated bouts of eccentric exercise on myogenic gene expression. Eur J Appl Physiol. 2007;101:427-36.

42. Kambadur R, Sharma M, Smith TP, Bass JJ. Mutations in myostatin (GDF8) in double-muscled Belgian Blue and Piedmontese cattle. Genome Res. 1997;7:910-6.

43. Mosher DS, Quignon P, Bustamante CD, Sutter NB, Mellersh CS, Parker HG, Ostrander EA. A mutation in the myostatin gene increases muscle mass and enhances racing performance in heterozygote dogs. PLoS Genet. 2007;3:e79.

44. Schuelke M, Wagner KR, Stolz LE, Hubner C, Riebel T, Komen W, Braun T, Tobin JF, Lee SJ. Myostatin mutation associated with gross muscle hypertrophy in a child. N Engl J Med. 2004;350:2682-8.

45. Cornelison DD, Olwin BB, Rudnicki MA, Wold BJ. MyoD(-/-) satellite cells in single-fiber culture are differentiation defective and MRF4 deficient. Dev Biol. 2000;224:122-37.

46. Thomas M, Langley B, Berry C, Sharma M, Kirk S, Bass J, Kambadur R. Myostatin, a negative regulator of muscle growth, functions by inhibiting myoblast proliferation. The J Biol Chem. 2000;275:40235-43.

47. Taylor WE, Bhasin S, Artaza J, Byhower F, Azam M, Willard DH, Jr., Kull FC, Jr., Gonzalez-Cadavid N. Myostatin inhibits cell proliferation and protein synthesis in $\mathrm{C} 2 \mathrm{C} 12$ muscle cells. Am J Physiol Endocrinol Metab. 2001;280:E221-8.

48. McFarlane C, Hui GZ, Amanda WZ, Lau HY, Lokireddy S, Xiaojia G, Mouly V, Butler-Browne G, Gluckman $\mathrm{PD}$, Sharma $\mathrm{M}$, et al. Human myostatin negatively regulates human myoblast growth and differentiation. Am J Physiol Cell Physiol. 2011;301:C195-203.

49. Wagner KR, Lziu X, Chang $X$, Allen RE. Muscle regeneration in the prolonged absence of myostatin. Proc Natl Acad Sci U S A. 2005;102:2519-24.

50. Amthor H, Macharia R, Navarrete R, Schuelke M, Brown SC, Otto A, Voit T, Muntoni F, Vrbova G, Partridge $T$, et al. Lack of myostatin results in excessive muscle growth but impaired force generation. Proc Natl Acad Sci U S A. 2007;104:1835-40.

51. Lee SJ, Huynh TV, Lee YS, Sebald SM, Wilcox-Adelman SA, Iwamori N, Lepper C, Matzuk MM, Fan CM. Role of satellite cells versus myofibers in muscle hypertrophy induced by inhibition of the myostatin/activin signaling pathway. Proc Natl Acad Sci U S A. 2012;109:E2353-60.

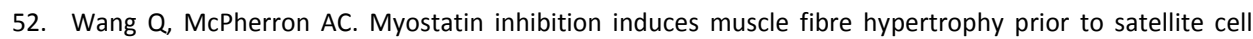
activation. J Physiol. 2012;590:2151-65.

53. Forbes D, Jackman M, Bishop A, Thomas M, Kambadur R, Sharma M. Myostatin auto-regulates its expression by feedback loop through Smad7 dependent mechanism. J Cell Physiol. 2006;206:264-72.

54. Kim JS, Petrella JK, Cross JM, Bamman MM. Load-mediated downregulation of myostatin mRNA is not sufficient to promote myofiber hypertrophy in humans: a cluster analysis. J Appl Physiol. 2007;103:148895.

55. Hulmi JJ, Kovanen V, Lisko I, Selanne H, Mero AA. The effects of whey protein on myostatin and cell cycle-related gene expression responses to a single heavy resistance exercise bout in trained older men. Eur J Appl Physiol. 2008;102:205-13.

56. Kim JS, Cross JM, Bamman MM. Impact of resistance loading on myostatin expression and cell cycle regulation in young and older men and women. Am J Physiol Endocrinol Metab. 2005;288:E1110-9.

57. Allen D, Cleary A, Lindsay S, Loh A, Reed J. Myostatin expression is increased by food deprivation in a muscle-specific manner and contributes to muscle atrophy during prolonged food deprivation in mice. J Appl Physiol. 2010;109:692-701.

58. Chauvigne F, Gabillard JC, Weil C, Rescan PY. Effect of refeeding on IGFI, IGFII, IGF receptors, FGF2, FGF6, and myostatin mRNA expression in rainbow trout myotomal muscle. Gen Comp Endocrinol. 2003;132:209-15.

59. Guernec A, Chevalier B, Duclos M. Nutrient supply enhances both IGF-I and MSTN mRNA levels in chicken skeletal muscle. Dom Animal Endocrinol. 2004;26:143-54.

60. Jeanplong F, Bass JJ, Smith HK, Kirk SP, Kambadur R, Sharma M, Oldham JM. Prolonged underfeeding of sheep increases myostatin and myogenic regulatory factor Myf-5 in skeletal muscle while IGF-I and myogenin are repressed. J Endocrinol. 2003;176:425-37. 
61. Ji S, Losinski R, Cornelius S, Frank G, Willis G, Gerrard D, Depreux F, Spurlock M. Myostatin expression in porcine tissues: tissue specificity and developmental and postnatal regulation. Am J of Physiol. 1998;275:73.

62. Han H, Zhou X, Mitch W, Goldberg A. Myostatin/activin pathway antagonism: Molecular basis and therapeutic potential. Int J Biochem Cell Biol. 2013;45:2333-47.

63. Schiaffino S, Dyar K, Ciciliot S, Blaauw B, Sandri M. Mechanisms regulating skeletal muscle growth and atrophy. FEBS J. 2013;280:4294-314.

64. Burd NA, Tang JE, Moore DR, Phillips SM. Exercise training and protein metabolism: influences of contraction, protein intake, and sex-based differences. J Appl Physiol. 2009;106:1692-701. 



\section{CHAPTER 8}

\section{Protein ingestion prior to sleep increases muscle mass gain during prolonged resistance type exercise training in young men}

Tim Snijders

Peter T. Res

Joey S.J. Smeets

Janneau van Kranenburg

Arie K. Kies

Kamiel Maase

Lex B. Verdijk

Luc J.C. van Loon

Medicine \& Science in Sports \& Exercise Submitted in 2014 


\begin{abstract}
Introduction: It has been demonstrated that protein ingestion prior to sleep increases muscle protein synthesis rates during overnight recovery from an exercise bout. However, it remains to be established whether dietary protein ingestion prior to sleep can effectively augment the skeletal muscle adaptive response to prolonged resistance type exercise training. In the present study we assessed the impact of dietary protein supplementation prior to sleep on muscle mass and strength gains during prolonged resistance type exercise training.
\end{abstract}

Methods: Forty-four healthy young men ( $22 \pm 1$ y) were randomly assigned to a progressive, 12-wk resistance type exercise training program (3 session/wk). One group consumed a protein supplement containing $27.5 \mathrm{~g}$ protein, $15 \mathrm{~g}$ carbohydrate, and $0.1 \mathrm{~g}$ fat every night prior to sleep. The other group received a non-caloric placebo. Muscle hypertrophy was assessed on a whole-body (DXA), limb (CT), and muscle fiber (biopsy) level prior to and after 12 weeks of training. Strength was assessed regularly by onerepetition maximum (1RM) strength testing.

Results: Muscle strength (total 1RM) increased following 12 wks of resistance type exercise training to a significant greater extent in the protein compared with the placebo supplemented group $(+164 \pm 11 \mathrm{~kg}$ and $+130 \pm 9 \mathrm{~kg}$, respectively; $P<0.0001)$. In addition, quadriceps muscle cross-sectional area increased in both groups over time $(P<0.0001)$, with a greater increase in the protein supplemented group $(+8.4 \pm 1.1$ vs $+4.8 \pm 0.8 \mathrm{~cm}^{2}$, respectively; $P<0.05$ ). Both type I and type II muscle fiber size increased following resistance type exercise training $(P<0.0001)$, with a greater increase in type II muscle fiber size in the protein $\left(+2319 \pm 368 \mu \mathrm{m}^{2}\right)$ compared with the placebo $\left(+1017 \pm 353 \mu \mathrm{m}^{2} ; P<0.05\right)$ group.

Conclusion: Protein ingestion prior to sleep represents an effective dietary strategy to augment muscle mass and strength gains during prolonged resistance type exercise training in healthy young males. 


\section{INTRODUCTION}

Resistance type exercise training represents an effective interventional strategy to augment skeletal muscle protein accretion $(1,2)$. A single bout of resistance type exercise stimulates both muscle protein synthesis and breakdown rates, albeit the latter to a lesser extent $(1,3,4)$. Though exercise improves net muscle protein balance, net muscle balance remains negative in the absence of nutrient intake $(1,3)$. Protein ingestion following exercise stimulates muscle protein synthesis, inhibits muscle protein breakdown, resulting in net muscle protein accretion during the acute stages of postexercise recovery (5-7). Therefore, it has been suggested that protein supplementation can further augment the muscle adaptive response to prolonged resistance type exercise training. However, studies investigating the impact of protein supplementation on muscle mass and strength gains during more prolonged resistance type exercise training tend to report discrepant findings. Whereas some studies report greater gains in muscle mass, muscle fiber size, and/or muscle strength following dietary protein supplementation during prolonged resistance-type exercise training (8-16), others have failed to confirm such findings (17-24). In a recent meta-analysis, Cermak et al. (25) showed that these discrepant findings may be largely explained by differences in study design and/or the number of participants included in the study. Other important factors that may contribute to the observed discrepancy on the proposed benefits of protein supplementation are the source and quantity of protein that is provided as well as the timing of protein supplementation (25). In recent studies, we have demonstrated that protein provided prior to sleep is properly digested and absorbed resulting in muscle protein accretion throughout overnight sleep $(26,27)$. When athletes were provided with a bolus of dietary protein immediately prior to sleep muscle protein synthesis rates were $\sim 22 \%$ higher during post-exercise overnight sleep when compared to the ingestion of a placebo (27). Consequently, we concluded that protein feeding prior to sleep may represent an effective interventional strategy to further augment the skeletal muscle adaptive response to exercise training and, as such, to improve exercise training efficiency. We hypothesized that dietary protein supplementation provided prior to sleep will further augment the gains in muscle mass, strength and muscle fiber size during more prolonged resistance type exercise training in healthy young men. Therefore, we subjected 44 healthy young men to a 12 wks resistance type exercise training program (three exercise sessions per week) during which they were provided with a protein supplement $(27.5 \mathrm{~g}$ protein-d-1) or a non-caloric placebo. Prior to and after the intervention period, we determined muscle mass on a whole-body, limb and muscle fiber level and assessed muscle strength. 


\section{Methods}

\section{Subjects}

A total of 44 healthy young men $(22 \pm 1$ y) volunteered to participate in a 12 -wk resistance type exercise training intervention program, with or without additional protein supplementation. Three subjects dropped out during the study, one because of a road accident, one because of pneumonia and one because of time availability. Medical history was evaluated, and a blood sample was taken to assess blood HbA1c content and fasting plasma glucose levels. Participants were excluded when $\mathrm{HbA} \mathrm{C}$ content exceeded $6.5 \%$ or fasting plasma glucose level was higher than $7 \mathrm{mmol} / \mathrm{L}$. Additional exclusion criteria that would preclude successful participation in the intervention program included (diagnosed) lactose intolerance and/or dairy protein allergy, COPD and/or orthopedic limitations. All subjects were recreationally active, performing sports on a non-competitive basis between 2 and $5 \mathrm{~h}$ per week. None of the participants had a history of participating in a structured resistance type exercise training program to improve performance over the past $2 \mathrm{y}$. All subjects were informed on the nature and possible risks of the experimental procedures before their written informed consent was obtained. This study was approved by the Medical Ethics Committee of the Maastricht University Medical Centre+, and complied with the guidelines set out in the Declaration of Helsinki.

\section{Study design}

After inclusion, subjects were randomly allocated to either a protein (PRO) or placebo (PLA) supplemented group. Before, during, and after exercise training, anthropometric measurements (height, body mass, and leg volume), strength assessment (one repetition maximum (1RM)), computed tomography (CT), and Dual-energy X-ray absorptiometry (DXA) scans were performed, and muscle biopsies and dietary intake records were collected.

\section{Exercise intervention program}

Supervised resistance type exercise training was performed three times a week for a 12 wk period. Training consisted of a 5 min warm-up on a cycle ergometer, followed by four sets on both the leg press and leg extension machines (Technogym, Rotterdam, the Netherlands), these two exercise were performed every training. Two sets on the chest press and horizontal row were alternated with vertical pull-down and shoulder press between every training session. Each session ended with a 5-min cooling down period on the cycle ergometer. During the first week of the training period, the workload was gradually increased from $70 \%$ (10-15 repetitions) of 1RM to $80 \%$ of 1RM (8-10 repetitions). Thereafter, training was always performed at $80 \% 1 \mathrm{RM}$. Resting periods of 1.5 and $3 \mathrm{~min}$ were allowed between sets and exercises, respectively. Workload intensi- 
ty was adjusted based on the outcome of the successive 1RM tests (performed at weeks 4 and 8). In addition, workload was increased when more than eight repetitions could be performed in three out of four sets. All training sessions were performed in the evening between $8.00-9.00 \mathrm{pm}$ or $9.00-10.00 \mathrm{pm}$. On average, subjects attended $91 \pm 1 \%$ and $90 \pm 1 \%$ of the scheduled exercise sessions in the PLA and PRO group, respectively, with no differences between groups.

\section{Dietary protein supplementation}

Throughout the 12 wk intervention period, subjects consumed a $300 \mathrm{~mL}$ bottle containing either a placebo (placebo group, PLA) or protein drink (protein group, PRO) daily prior to sleep. The protein beverage contained $13.75 \mathrm{~g}$ casein hydrolysate (Peptopro), $13.75 \mathrm{~g}$ casein, $15 \mathrm{~g}$ carbohydrate and $0.1 \mathrm{~g}$ fat (DSM, Delft, the Netherlands), providing $746 \mathrm{~kJ}$ of energy. The control drink was a non-caloric placebo beverage. Beverages were masked for taste and smell by adding citric and vanilla additives. In addition, beverages were masked for color by adding titanium dioxide (E171) to the placebo drink. Placebo and protein drinks were provided in a randomized, double-blind manner. On average, subjects consumed $98 \pm 1 \%$ of the beverages, with no differences between groups.

\section{Dietary intake and physical activity standardization}

All participants received a snack immediately after every training session, including a cheese sandwich, an apple and a non-caloric beverage (total energy intake $1151 \mathrm{~kJ} ; 37$ $\mathrm{g}$ carbohydrates, $10 \mathrm{~g}$ protein and $9 \mathrm{~g}$ fat). Furthermore, standardized meals were provided to all subjects the evening before each test day. The subjects were instructed to refrain from strenuous physical activity for at least $5 \mathrm{~d}$ before testing. On all test days, subjects arrived at the laboratory by car or public transportation after an overnight fast. Subjects were encouraged to maintain their habitual dietary intake and physical activity pattern throughout the intervention program. Before the onset of the intervention program and in week 11 of the exercise intervention, the participants recorded 3-d weighted dietary intake records (Thursday-Saturday) to assess potential changes in daily food intake that might have occurred during the intervention period. Food intake records were analyzed with Eetmeter software 2005 (version1.4.0; Voedingscentrum, The Hague, Netherlands).

\section{Body composition}

Body composition was measured using DXA (Discovery A, QDR Series; Hologic, Bradford, MA). Whole-body and regional lean mass, and fat mass, were determined by using the system's software package Apex version 2.3 Wind River, Alameda, CA). Anthropometrics were assessed using standardized procedures; bodyweight by digital scale to within $100 \mathrm{~g}$; height by stadiometer to within $0.5 \mathrm{~cm}$. Anatomical cross-sectional area (CSA) of the quadriceps muscle was assessed by CT scanning (Philips Brilliance 64, Philips Medical Systems, Best, the Netherlands) before and after 12 wk of intervention. 
The scanning characteristics were as follows: $120 \mathrm{kV}, 300 \mathrm{~mA}$, rotation time of $0.75 \mathrm{~s}$, and a field of view of $500 \mathrm{~mm}$. The subjects were lying supine, legs extended and their feet secured, a 3-mm-thick axial image was taken $15 \mathrm{~cm}$ proximal to the base of the patella. The exact scanning position was measured and marked for replication at subsequent visits. Muscle area of the right leg was selected between 0 and 100 Hounsfield units (28), after which, the quadriceps muscle was selected by manual tracing using ImageJ software (version 1.45d; National Institutes of Health, Bethesda, MD) (29). All analyses were performed by two investigators blinded to subject coding; intra-class correlation coefficients for inter- and intra-investigator reliability were 1.000 and 0.997 , respectively.

\section{Muscle biopsy sampling}

Seven days before the onset of the intervention and after 12 wk of intervention ( $5 \mathrm{~d}$ after final strength testing), muscle biopsies were taken from the right leg of each subject in the morning after an overnight fast. After local anesthesia was induced, percutaneous needle biopsy samples (50-80 mg) were collected from the vastus lateralis muscle, approximately $15 \mathrm{~cm}$ above the patella (30). Any visible non-muscle tissue was removed immediately, and biopsy samples were embedded in Tissue-Tek (Sakura Finetek, Zoeterwoude, the Netherlands), frozen in liquid nitrogen-cooled isopentane, and stored at $-80 \mathrm{C}$ until further analyses.

\section{Strength assessment}

Maximum strength was assessed by $1 \mathrm{RM}$ strength tests on leg press, leg extension, chest press, shoulder press, vertical pull down and horizontal row machines (Technogym). During a familiarization trial, proper lifting technique was demonstrated and practiced and maximum strength was estimated using the multiple repetitions testing procedure. In an additional session, at least 1 week before muscle biopsy collection, each subjects 1-RM was determined as described previously (31). Therefore, 1RM testing is preferred to evaluate changes in muscle strength during resistance-type exercise training (32). Therefore, $1 \mathrm{RM}$ tests for leg press and leg extension machines were repeated after 4 and 8 wks of intervention to adjust training weights. In addition, all 1RM were repeated $4 \mathrm{~d}$ after the last training session of the intervention program.

\section{Immunohistochemistry}

From all biopsies, 5- $\mathrm{mm}$-thick cryosections were cut at $-20^{\circ} \mathrm{C}$. Samples collected before and after 12 wks of intervention from each subject were mounted together on uncoated glass slides. Muscle biopsies were stained for muscle fiber typing as described in detail previously $(33,34)$. In short, the slides were incubated with primary antibodies against MHC-I (A4.840; Developmental Studies Hybridoma Bank, lowa City, IA) and laminin (polyclonal laminin; Sigma, Zwijndrecht, the Netherlands). After washing, appropriate secondary antibodies were applied (goat anti-mouse IgM AlexaFluor555 and 
goat anti-rabbit IgG AlexaFluor647, respectively; Molecular Probes, Invitrogen, Breda, the Netherlands). Images were visualized and automatically captured at 10x magnification with a fluorescent microscope equipped with an automatic stage (IX81 motorized inverted microscope; Olympus, Hamburg, Germany). Muscle fiber type (fiber\%) and fiber CSA were measured for each separate muscle fiber. As such, mean muscle fiber size was calculated for the type I and type II muscle fibers separately. As a measure of fiber circularity, form factors were calculated by using the following formula: $(4 \pi \cdot \mathrm{csa}) /$ (perimeter) $^{2}$. All image recordings and analyses were performed by an investigator blinded to subject coding. No differences in fiber circularity were observed over time or between groups. Mean numbers of $149 \pm 11$, and $182 \pm 14$ muscle fibers were analyzed in the biopsy samples collected before and after 12 wk of intervention, respectively.

\section{Statistics}

All data are expressed as means \pm SEMs. Baseline characteristics between groups were compared by means of an Independent-samples T Test. Because all data were normally distributed, training-induced changes were analyzed with a split plot model with treatment (protein vs placebo group) and training (before vs after training) as fixed factors and subject as a within-treatment random factor. Muscle fiber type-specific variables were analyzed by adding another fixed factor (type I vs type II fibers). In case of a significant interaction, Paired-samples T Tests were performed to determine training effects within treatment groups or within type I or II fibers. Independent-samples T tests were used to determine group differences in either the pre- or post-intervention values. Bonferroni corrections were applied where appropriate. All analyses were performed by using SAS (SAS Institute Inc, Cary, NC). An $\alpha$-level of 0.05 was used to determine statistical significance.

\section{Results}

\section{Participants}

Participants' characteristics are provided in Table 1. In total 41 participants completed the intervention program. Two participants were excluded from the analysis, one participant missed too many training sessions and one participant missed too many test beverages. Subsequently, analysis was performed on 39 participants: 20 in the PLA group and 19 in the PRO group. At baseline no differences in age, body mass, height, $\mathrm{BMI}$ and leg volume were observed between the PLA and PRO group (Table 1). We observed a significant increase in body mass from $80.0 \pm 2.5$ to $81.0 \pm 2.7 \mathrm{~kg}$ and from $76.2 \pm 2.1$ to $78.9 \pm 2.3 \mathrm{~kg}$ in response to $12 \mathrm{wks}$ of resistance type exercise training in both the PLA and PRO group, respectively $(P<0.05)$. Body mass index increased significantly over time (from $23.4 \pm 0.8$ to $23.7 \pm 0.8 \mathrm{~kg} \cdot \mathrm{m}^{-2}$ and from $23.2 \pm 0.6$ to $23.8 \pm 0.6 \mathrm{~kg} \cdot \mathrm{m}^{-}$ 
${ }^{2}$ in the PLA and PRO group, respectively; $\left.P<0.05\right)$. Furthermore, leg volume increased significantly in both groups in response to resistance type exercise training (from 9.3 \pm 0.3 to $9.7 \pm 0.3 \mathrm{~L}$ and from $8.9 \pm 0.3$ to $9.1 \pm 0.3 \mathrm{~L}$ in the PLA and PRO group, respectively; $P<0.05)$. No significant differences were observed between treatments.

Table 1 Participants' characteristics

\begin{tabular}{lcc}
\hline & Placebo group & Protein group \\
\hline Age $(\mathrm{y})$ & $21 \pm 1$ & $23 \pm 1$ \\
Height $(\mathrm{m})$ & $1.85 \pm 0.02$ & $1.82 \pm 0.02$ \\
Body mass $(\mathrm{kg})$ & $80.0 \pm 2.5$ & $76.9 \pm 2.1$ \\
$\mathrm{BMI}\left(\mathrm{kg} \cdot \mathrm{m}^{-2}\right)$ & $23.4 \pm 0.8$ & $23.2 \pm 0.6$ \\
Leg (right) volume $(\mathrm{L})$ & $9.3 \pm 0.3$ & $8.9 \pm 0.3$ \\
\hline
\end{tabular}

Values are means \pm SEM; BMI, body mass index. No significant differences were observed between groups

\section{Body composition}

At baseline, no significant differences were observed between the PLA and PRO group for any of the DXA-scan measurements. Whole-body lean mass increased throughout the intervention period in both the PLA and PRO group, from $63.6 \pm 1.6$ to $65.3 \pm 1.7 \mathrm{~kg}$ and $62.9 \pm 1.3$ to $64.8 \pm 1.4 \mathrm{~kg}$, respectively $(P<0.001)$, with no difference between the PLA and PRO group. Leg lean mass (left + right) increased significantly by $607 \pm 121$ and $842 \pm 129 \mathrm{~g}$ following $12 \mathrm{wks}$ of resistance type exercise training in the PLA and PRO group, respectively, with no significant difference between groups. Though no significant changes were observed in total fat mass in the PLA and PRO groups, we did show a significant decline in whole-body and leg fat percentage in response to 12 wks of resistance type exercise training (Table $2 ; P<0.05)$. No significant differences were observed between groups.

Table 2 Body composition

\begin{tabular}{lcccccc}
\hline & \multicolumn{3}{c}{ Placebo group } & \multicolumn{3}{c}{ Protein group } \\
\cline { 2 - 7 } & Before & After & $\Delta$ Change & Before & After & $\Delta$ Change \\
\hline Whole-body lean mass $(\mathrm{kg})$ & $63.6 \pm 1.6$ & $65.3 \pm 1.7^{*}$ & $1.7 \pm 0.3$ & $62.9 \pm 1.3$ & $64.8 \pm 1.4^{*}$ & $1.9 \pm 0.4$ \\
Trunk lean mass $(\mathrm{kg})$ & $30.7 \pm 0.8$ & $31.4 \pm 0.8^{*}$ & $0.7 \pm 0.2$ & $30.7 \pm 0.8$ & $31.4 \pm 0.8^{*}$ & $0.6 \pm 0.2$ \\
Leg lean mass $(\mathrm{kg})$ & $22.3 \pm 0.6$ & $23.0 \pm 0.7^{*}$ & $0.6 \pm 0.1$ & $21.6 \pm 0.5$ & $22.5 \pm 0.5^{*}$ & $0.8 \pm 0.1$ \\
\hline
\end{tabular}

Values are means \pm SEM. No training $x$ treatment interaction was observed for any of the variables $(P \geq 0.19)$. * Significant main effect of training $(P<0.001)$. No significant main effect of treatment was observed for any of the variables.

\section{Skeletal muscle hypertrophy}

At baseline, no significant differences in quadriceps muscle CSA were observed between the PLA and PRO group (Figure 1). Quadriceps muscle CSA increased in both groups $(P<0.0001)$, with a greater increase in the PRO compared with the PLA group 
$(+8.4 \pm 1.1$ vs $+4.8 \pm 0.8 \mathrm{~cm} 2$, respectively; $P<0.05$; Figure 1$)$. Prior to intervention, no significant differences were observed in type I and type II muscle fiber size between PLA and PRO group. We observed a significant fiber type $x$ time $x$ treatment interaction $(P<0.05)$. Separate analyses showed that type I muscle fiber size had increased in both the PLA and PRO group in response to 12 wks of resistance type exercise training $(P<0.05)$, with no differences between groups (time $x$ treatment interaction $P=0.234$ ). Type II muscle fiber size increased in both groups $(P<0.0001)$, with a greater increase in the PRO compared with the PLA group (from $6017 \pm 204$ to $8290 \pm 361 \mu \mathrm{m}^{2}$ and from $6371 \pm 297$ to $7372 \pm 296 \mu \mathrm{m}^{2}$, respectively; time $\mathrm{x}$ treatment interaction $P<0.05$; Figure 2).

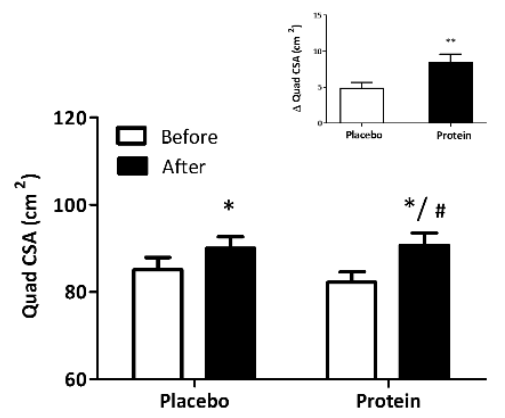

Figure 1 Mean $( \pm S E M)$ quadriceps cross-sectional area (CSA) before and after 12 wks of resistance type exercise training in healthy young men with (protein group; $\mathrm{n}=19$ ) or without (placebo group; $n=20$ ) protein supplementation prior to sleep. *Significantly different from before intervention, $P<0.001$. \# Significant training $x$ treatment interaction, $P<0.05$. **Significantly different from placebo group, $P<0.05$.
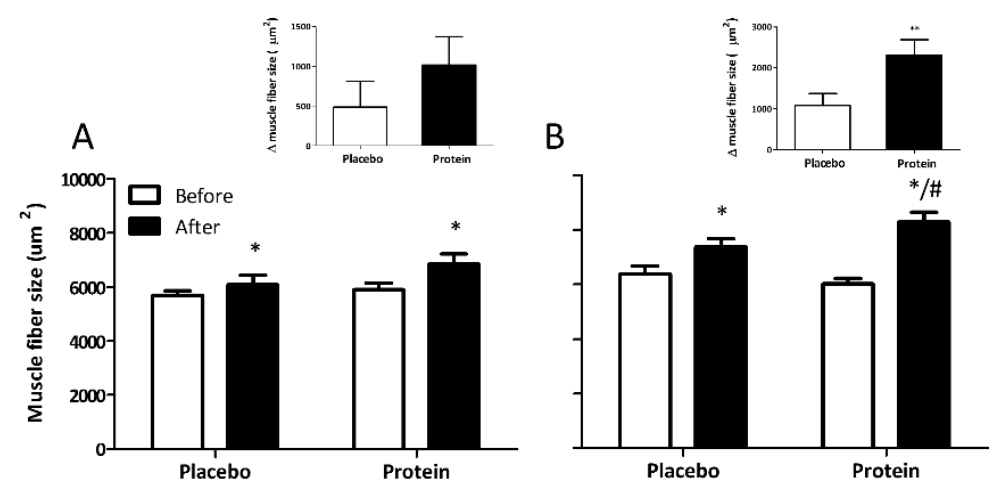

Figure 2 Mean ( \pm SEM) muscle fiber size for type I (A) and II (B) muscle fiber size before and after 12 wks of resistance type exercise training in healthy young men with (protein group; $n=19$ ) or without (placebo group; $n=20$ ) protein supplementation prior to sleep. We observed a training $x$ fiber type $x$ treatment interaction $(P<0.05)$. Type I and type II muscle fibers were analyzed separately. * Significant training effect in type I and II muscle fibers was observed $P<0.05$ and $P<0.001$, respectively. In type I muscle fibers no training $x$ treatment $(P=0.23)$ interaction was observed. \# Significant greater increases in type II muscle fiber size were observed in the protein compared with the placebo group, significant training $x$ treatment interaction $(P<0.05)$. ${ }^{*}$ Significantly different from placebo group, $P<0.05$. 


\section{Muscle fiber type composition}

At baseline, no group differences were observed in the percentage of type I and type II muscle fibers (fiber\%) and/or the percentage of muscle area occupied by type I and II fibers (area\%). Type I and II muscle fiber\% did not change in both groups after 12 wks of exercise intervention (Table 3). In contrast, type II muscle fiber area\% increased significantly from $54 \pm 3 \%$ to $65 \pm 3 \%$ in the PRO group following resistance type exercise training $(P<0.05)$, whereas no changes were observed in the PLA group.

Table 3 Muscle fiber type composition

\begin{tabular}{lccccc}
\hline & Fiber & \multicolumn{2}{c}{ Placebo group } & \multicolumn{2}{c}{ Protein group } \\
\cline { 2 - 5 } & type & Before & After & Before & After \\
\hline Fiber \% & I & $46 \pm 3$ & $45 \pm 3$ & $46 \pm 3$ & $40 \pm 3$ \\
& II & $54 \pm 3$ & $55 \pm 3$ & $54 \pm 3$ & $60 \pm 3$ \\
CSA \% & I & $43 \pm 3$ & $41 \pm 3$ & $46 \pm 3$ & $35 \pm 3$ \\
& II & $56 \pm 3$ & $59 \pm 3$ & $54 \pm 3$ & $65 \pm 3 *$ \\
\hline
\end{tabular}

Values are means \pm SEM; CSA, cross-sectional area. No significant differences were observed between groups prior to intervention. * Significant training $x$ treatment interaction, $\mathrm{P}<0.05$ showed that muscle fiber CSA\% changed due to training in the protein group only.

\section{Muscle strength}

At baseline no significant differences in 1RM muscle strength were observed between the PLA and PRO group (Table 4). After 12 wks of resistance type exercise training leg press and leg extension muscle strength had increased significantly in both groups $(P<0.0001)$, with no differences between groups. Similarly, for the upper body exercises (chest press, shoulder press, and horizontal row) we observed a significant increase in $1 \mathrm{RM}$ muscle strength over time $(P<0.0001)$, with no differences between the PLA and PRO groups.

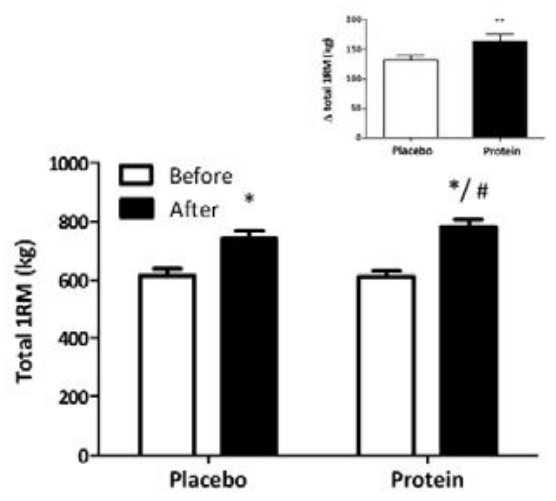

Figure 3. Mean ( \pm SEM) one repetition maximum (sum of all 1RM test) strength before and after 12 wks of resistance type exercise training in healthy young men with (protein group; $\mathrm{n}=20$ ) or without (placebo group; $n=19$ ) protein supplementation prior to sleep. *Significantly different from data observed prior to intervention, $P<0.001$. \# Significant training $x$ treatment interaction, $P<0.05$. **Significantly different from placebo group, $P<0.05$. 
On the lateral pull down machine we found significantly greater muscle strength gains in the PRO (from $66 \pm 2$ to $79 \pm 2 \mathrm{~kg}$ ) compared with the PLA (from $67 \pm 3$ to $76 \pm 3 \mathrm{~kg}$ ) group (main effect of time; $P<0.0001$ and time $x$ treatment interaction; $P<0.05$ ). Furthermore, we observed that the sum of all $1 \mathrm{RM}$ measurements increased to a larger extent in the PRO (from $615 \pm 24$ to $741 \pm 26 \mathrm{~kg}$ ) compared with the PLA (from $611 \pm 20$ to $783 \pm 25 \mathrm{~kg}$ ) group (main effect of time, $P<0.0001$; and time $x$ treatment interaction, $P<0.05$; Figure 3).

Table 4 Muscle strength

\begin{tabular}{|c|c|c|c|c|c|c|c|c|}
\hline & \multicolumn{4}{|c|}{ Placebo group } & \multicolumn{4}{|c|}{ Protein group } \\
\hline & Before & $4 w k$ & $8 w k$ & After & Before & 4 wk & $8 w k$ & After \\
\hline Leg press (kg) & $197 \pm 9$ & $220 \pm 10^{*}$ & $226 \pm 9 *^{\#}$ & $238 \pm 10 *^{\#}$ & $195 \pm 6$ & $229 \pm 9 *$ & $244 \pm 9 *^{\#}$ & $254 \pm 13^{* \#}$ \\
\hline Leg extension (kg) & $122 \pm 5$ & $134 \pm 4^{*}$ & $144 \pm 6 *^{\#}$ & $151 \pm 6^{*^{\#+}}$ & $114 \pm 5$ & $135 \pm 5^{*}$ & $144 \pm 8^{* \#}$ & $146 \pm 52^{*^{\#+}}$ \\
\hline Chest press (kg) & $86 \pm 5$ & - & - & $109 \pm 5 *$ & $88 \pm 5$ & - & - & $115 \pm 7^{*}$ \\
\hline Shoulder press (kg) & $80 \pm 5$ & - & - & $93 \pm 4 *$ & $85 \pm 5$ & - & - & $104 \pm 6^{*}$ \\
\hline Horizontal row (kg) & $62 \pm 2$ & - & - & $72 \pm 3 *$ & $62 \pm 2$ & - & - & $75 \pm 2 *$ \\
\hline Vertical pull down (kg) & $67 \pm 3$ & - & - & $76 \pm 3 * \ddagger$ & $66 \pm 2$ & - & - & $79 \pm 2 *$ \\
\hline Total 1RM & $615 \pm 24$ & - & - & $741 \pm 26 * \ddagger$ & $611 \pm 20$ & - & - & $783 \pm 25 * \ddagger$ \\
\hline
\end{tabular}

\section{Dietary intake records}

Analysis of the 3-d dietary intake records collected before and after 11 wk of resistance type exercise training showed no differences in total daily energy intake between groups and/or over time $(12.0 \pm 0.7$ and $11.5 \pm 0.7 \mathrm{MJ} / \mathrm{d}$ to $10.8 \pm 0.6$ and $11.4 \pm 0.7 \mathrm{MJ} / \mathrm{d}$ in the PLA and PRO groups, respectively). We observed a significant increase in the \%energy of protein intake during the $12 \mathrm{wk}$ intervention period $(P<0.05)$, with no differences between groups (Table 5). Daily protein intake averaged $1.3 \pm 0.1 \mathrm{~g}^{\mathrm{kg}} \mathrm{gg}^{-1} \cdot \mathrm{d}^{-1}$ in both groups and did not change significantly during the intervention period. As a result of the supplementation regime, protein intake increased to $1.9 \pm 0.1 \mathrm{~g} \cdot \mathrm{kg}^{-1} \cdot \mathrm{d}^{-1}$ in the PRO group (Table 5). 
Table 5 Energy intake and macronutrient composition of the diet

\begin{tabular}{lcccc}
\hline & \multicolumn{2}{c}{ Placebo group } & \multicolumn{2}{c}{ Protein group } \\
\cline { 2 - 5 } & Before & After & Before & After \\
\hline Total Energy (MJ/d) & $12.0 \pm 0.7$ & $10.8 \pm 0.6$ & $11.5 \pm 0.7$ & $11.4 \pm 0.7$ \\
Carbohydrate (\% of energy) & $47 \pm 1$ & $48 \pm 1$ & $45 \pm 2$ & $43 \pm 3$ \\
Fat (\% of energy) & $35 \pm 1$ & $34 \pm 1$ & $36 \pm 2$ & $35 \pm 2$ \\
Alcohol (\% of energy) & $3 \pm 1$ & $1 \pm 1$ & $5 \pm 1$ & $5 \pm 2$ \\
Protein (\% of energy) & $15 \pm 1$ & $17 \pm 1^{*}$ & $15 \pm 1$ & $16 \pm 1^{*}$ \\
Protein intake $(\mathrm{g})$ & $101 \pm 6$ & $103 \pm 7$ & $99 \pm 5$ & $106 \pm 8$ \\
Protein intake $\left(\mathrm{g} \cdot \mathrm{kg}^{-1} \cdot \mathrm{d}^{-1}\right.$ ) & $1.3 \pm 0.1$ & $1.3 \pm 0.1$ & $1.3 \pm 0.1$ & $1.4 \pm 0.1$ \\
Protein intake including supplement $\left(\mathrm{g} \cdot \mathrm{kg}^{-1} \cdot \mathrm{d}^{-1}\right)$ & $1.3 \pm 0.1$ & $1.3 \pm 0.1$ & $1.3 \pm 0.1$ & $1.9 \pm 0.1^{\#+}$ \\
\hline
\end{tabular}

Values are means \pm SEM. ${ }^{*}$ Significantly different compared with before intervention $(P<0.05)$. * Significant training $\mathrm{x}$ treatment interaction $(P<0.05)$ showed a change after training in the protein group only $(P<0.001)$.

\section{DISCUSSION}

The present study shows that 3 months of resistance type exercise training increases skeletal muscle mass, strength, and muscle fiber size in young males. The exercise training induced gains in muscle mass and strength are shown to be further increased following daily supplementation with $27.5 \mathrm{~g}$ dietary protein consumed prior to sleep.

It has been well-established that long-term resistance type exercise training is an effective intervention strategy to increase skeletal muscle mass and strength (8-24). In the present study, we show substantial increases in whole body lean mass $(1.7 \pm 0.3 \mathrm{~kg})$ following $12 \mathrm{wk}$ of resistance type exercise training. The observed gains in muscle mass are in line with previous findings reported after 8-16 wks of resistance type exercise training in healthy young men (25). The increase in whole body lean mass was mainly attributed to an increase in leg and trunk lean mass $(0.6 \pm 0.2$ and $0.7 \pm 0.1 \mathrm{~kg}$, respectively). These gains in muscle mass were accompanied by a $6 \pm 1 \%$ increase in Quadriceps muscle CSA following 12 wks of resistance type exercise training. In agreement, on a myocellular level we also observed a significant increase in muscle fiber size in response to exercise training. Previous studies have reported mixed results on either type I or type II muscle fiber hypertrophy after prolonged resistance type exercise training. Whereas some demonstrate an increase in type I and/or type II muscle fiber size (8-10, $35)$, others have been unable to demonstrate muscle fiber hypertrophy in response to prolonged resistance type exercise training $(15,36)$. In the present study, we report a significant increase in both type I $\left(+483 \pm 329 \mu \mathrm{m}^{2}\right)$ and type II $\left(+1017 \pm 353 \mu \mathrm{m}^{2}\right)$ muscle fiber size in response to exercise training. Skeletal muscle mass and/or CSA are known to be positively correlated with skeletal muscle strength $(34,37)$. In accordance we observed a substantial $23 \pm 2$ and $25 \pm 2 \%$ increase in leg extension and leg press strength, respectively.

It has been suggested that protein supplementation can further augment the skeletal 
muscle adaptive response to prolonged resistance type exercise training (25). However, there is much discrepancy in the literature on the proposed benefits of protein supplementation to increase muscle mass and strength, with most studies unable to report significantly greater increases in muscle mass or strength following prolonged resistance type exercise training (17-24). In the present study, we provided additional protein on a daily basis prior to sleep over the course of a $12 \mathrm{wk}$ resistance type exercise training program. Participants in the PRO supplemented group showed greater gains in muscle quadriceps CSA $(+10 \pm 1 \%)$ compared with the PLA group $(+6 \pm 1 \%)$ after the exercise intervention (time $x$ treatment interaction, $P=0.027$; Figure 1 ). This also translated into a greater gain in total $1 R M$ muscle strength in the PRO compared with the PLA group (Figure 3). Though leg lean mass appeared to increase to a larger extent in the PRO ( $+842 \pm 129 \mathrm{~g})$ compared with the PLA (+610 $\pm 129 \mathrm{~g})$ group, differences between groups did not reach statistical significance (time $x$ treatment interaction; $\mathrm{P}=0.192)$. On the muscle fiber level, we observed a significantly greater increase in type II muscle fiber size in the PRO group $\left(+41 \pm 6 \%\right.$ or $\left.+2319 \pm 368 \mu \mathrm{m}^{2}\right)$ when compared with the PLA group $\left(+19 \pm 6 \%\right.$ or $\left.+1017 \pm 353 \mu \mathrm{m}^{2}\right)$ in response to the 12 wk resistance type exercise training program (Figure 2 ). These results clearly show that protein supplementation, as performed in the present study, further augmented the skeletal muscle adaptive response to prolonged resistance type exercise training. This seems to be in line with some (8-16) but certainly not all studies (17-24) that investigated the impact of protein supplementation during prolonged resistance type exercise training. The obvious discrepancy in the literature is likely to be attributed to differences in research design, but also in particularly the choice of the type, source and timing of the protein supplement that is provided. In the present study we provided protein prior to sleep, with exercise being performed in the evening on the training days. This seems to be a more practical strategy and may be of greater efficacy as previous studies from our lab have shown that protein ingestion prior to sleep is properly digested and absorbed during the night allowing muscle protein to be synthesized during sleep $(26,27)$. Dietary protein supplementation prior to sleep is here shown to represent a feasible and effective nutritional strategy to support the skeletal muscle adaptive response to prolonged resistance type exercise training, thereby increasing training efficiency. We can only speculate on the surplus benefits of the protein supplement being provided prior to sleep as opposed to a different time points throughout the day. However, as dietary protein is provided at most mean meals throughout the day we feel that dietary protein supplementation prior to sleep is of particular relevance, certainly under conditions where habitual dietary protein intake is already high $(1.3 \pm 0.1 \mathrm{~g}$ protein per $\mathrm{kg}$ body weight in the young, recreationally active subjects included in the present study (Table 5)). Consequently, it is quite astounding that even at such a high absolute dietary protein intake a nighttime based protein supplement was able to augment muscle mass and strength gains.

In the present study, we provided participants in the PRO group with a beverage con- 
taining both carbohydrates (15 g) and protein $(27.5 \mathrm{~g})$, in total the supplement provided $\sim 746 \mathrm{~kJ}$. In the control group participants received a non-caloric placebo beverage. We chose to provide a non-caloric placebo in the control group to prevent any shifts in macronutrient composition of the diet in the control group. An iso-energetic control supplement with carbohydrate (i.e. $\sim 45 \mathrm{~g} \mathrm{CHO}$ ) could have resulted in a decline in protein intake in the control group, thereby increasing the risk of finding a false positive outcome regarding the proposed benefits of protein supplementation. Nonetheless, we observed no changes in total energy intake (including the protein supplement) over time in both the PRO and PLA groups (Table 5). We did show a significant increase in energy\% protein in the diet in both groups during the intervention (Table 5). However, in the PRO group dietary protein intake was elevated towards $1.9 \pm 0.1 \mathrm{~g} / \mathrm{kg} /$ day, whereas protein intake in the control group remained at a level of $1.3 \pm 0.1 \mathrm{~g} / \mathrm{kg} / \mathrm{d}$ during the 3 month intervention period (Table $5, \mathrm{P}<0.05$ ).

It is evident that a discrepancy exists in the literature on the surplus benefits of dietary protein supplementation during prolonged resistance type exercise training. These discrepant findings are, at least partly, attributed to less favorable choices in the protein source and protein quantity provided, habitual protein intake and the timing of protein supplementation that was applied in the study. The present study confirms observation in our previous work that provision of dietary protein prior to sleep is well received and well-tolerated by the athletes and represents a feasible interventional strategy to augment the skeletal muscle adaptive response to resistance type exercise training.

In conclusion, protein ingestion prior to sleep represents an effective dietary strategy to augment skeletal muscle mass and strength gains during prolonged resistance type exercise training in healthy young males. 


\section{RefERENCES}

1. Phillips SM, Tipton KD, Aarsland A, Wolf SE, Wolfe RR. Mixed muscle protein synthesis and breakdown after resistance exercise in humans. Am J Physiol 1997;273:E99-107.

2. Chesley A, MacDougall JD, Tarnopolsky MA, Atkinson SA, Smith K. Changes in human muscle protein synthesis after resistance exercise. J Appl Physiol 1992;73:1383-8.

3. Biolo G, Maggi SP, Williams BD, Tipton KD, Wolfe RR. Increased rates of muscle protein turnover and amino acid transport after resistance exercise in humans. Am J Physiol 1995;268:E514-20.

4. Tipton KD, Ferrando AA, Williams BD, Wolfe RR. Muscle protein metabolism in female swimmers after a combination of resistance and endurance exercise. J Appl Physiol 1996;81:2034-8.

5. Biolo G, Tipton KD, Klein S, Wolfe RR. An abundant supply of amino acids enhances the metabolic effect of exercise on muscle protein. Am J Physiol 1997;273:E122-9.

6. Borsheim E, Tipton KD, Wolf SE, Wolfe RR. Essential amino acids and muscle protein recovery from resistance exercise. Am J Physiol Endocrinol Metab 2002;283:E648-57.

7. Koopman R, Walrand S, Beelen M, Gijsen AP, Kies AK, Boirie Y, Saris WH, van Loon LJ. Dietary protein digestion and absorption rates and the subsequent postprandial muscle protein synthetic response do not differ between young and elderly men. J Nutr 2009;139:1707-13.

8. Bird SP, Tarpenning KM, Marino FE. Independent and combined effects of liquid carbohydrate/essential amino acid ingestion on hormonal and muscular adaptations following resistance training in untrained men. Eur J Appl Physiol 2006;97:225-38.

9. Cribb PJ, Williams AD, Stathis CG, Carey MF, Hayes A. Effects of whey isolate, creatine, and resistance training on muscle hypertrophy. Med Sci Sports Exerc 2007;39:298-307.

10. Hartman JW, Tang JE, Wilkinson SB, Tarnopolsky MA, Lawrence RL, Fullerton AV, Phillips SM. Consumption of fat-free fluid milk after resistance exercise promotes greater lean mass accretion than does consumption of soy or carbohydrate in young, novice, male weightlifters. Am J Clin Nutr 2007;86:373-81.

11. Josse AR, Tang JE, Tarnopolsky MA, Phillips SM. Body composition and strength changes in women with milk and resistance exercise. Med Sci Sports Exerc 2010;42:1122-30.

12. Kerksick CM, Rasmussen $\mathrm{CJ}$, Lancaster $\mathrm{SL}$, et al. The effects of protein and amino acid supplementation on performance and training adaptations during ten weeks of resistance training. J Strength Cond Res 2006;20:643-53.

13. Willoughby DS, Stout JR, Wilborn CD. Effects of resistance training and protein plus amino acid supplementation on muscle anabolism, mass, and strength. Amino Acids 2007;32:467-77.

14. Candow DG, Burke NC, Smith-Palmer T, Burke DG. Effect of whey and soy protein supplementation combined with resistance training in young adults. Int J Sport Nutr Exerc Metab 2006;16:233-44.

15. Andersen LL, Tufekovic G, Zebis MK, Crameri RM, Verlaan G, Kjaer M, Suetta C, Magnusson P, Aagaard P. The effect of resistance training combined with timed ingestion of protein on muscle fiber size and muscle strength. Metabolism 2005;54:151-6.

16. Vieillevoye S, Poortmans JR, Duchateau J, Carpentier A. Effects of a combined essential amino acids/carbohydrate supplementation on muscle mass, architecture and maximal strength following heavy-load training. Eur J Appl Physiol 2010;110:479-88.

17. Rankin JW, Goldman LP, Puglisi MJ, Nickols-Richardson SM, Earthman CP, Gwazdauskas FC. Effect of post-exercise supplement consumption on adaptations to resistance training. J Am Coll Nutr 2004;23:322-30.

18. Rozenek R, Ward P, Long S, Garhammer J. Effects of high-calorie supplements on body composition and muscular strength following resistance training. J Sports Med Phys Fitness 2002;42:340-7.

19. White KM, Bauer SJ, Hartz KK, Baldridge M. Changes in body composition with yogurt consumption during resistance training in women. Int J Sport Nutr Exerc Metab 2009;19:18-33.

20. Beck TW, Housh TJ, Johnson GO, Coburn JW, Malek MH, Cramer JT. Effects of a drink containing creatine, amino acids, and protein combined with ten weeks of resistance training on body composition, strength, and anaerobic performance. J Strength Cond Res 2007;21:100-4. 
21. Chromiak JA, Smedley B, Carpenter W, Brown R, Koh YS, Lamberth JG, Joe LA, Abadie BR, Altorfer G. Effect of a 10-week strength training program and recovery drink on body composition, muscular strength and endurance, and anaerobic power and capacity. Nutrition 2004;20:420-7.

22. Lemon PW, Tarnopolsky MA, MacDougall JD, Atkinson SA. Protein requirements and muscle mass/strength changes during intensive training in novice bodybuilders. J Appl Physiol 1992;73:767-75.

23. Antonio J, Sanders MS, Ehler LA, Uelmen J, Raether JB, Stout JR. Effects of exercise training and aminoacid supplementation on body composition and physical performance in untrained women. Nutrition 2000;16:1043-6.

24. Hoffman JR, Ratamess NA, Tranchina CP, Rashti SL, Kang J, Faigenbaum AD. Effect of protein-supplement timing on strength, power, and body-composition changes in resistance-trained men. Int J Sport Nutr Exerc Metab 2009;19:172-85.

25. Cermak NM, Res PT, de Groot LC, Saris WH, van Loon LJ. Protein supplementation augments the adaptive response of skeletal muscle to resistance-type exercise training: a meta-analysis. The American journal of clinical nutrition 2012;96:1454-64.

26. Groen BB, Res PT, Pennings B, Hertle E, Senden JM, Saris WH, van Loon LJ. Intragastric protein administration stimulates overnight muscle protein synthesis in elderly men. Am J Physiol Endocrinol Metab 2012;302:E52-60.

27. Res PT, Groen B, Pennings B, Beelen M, Wallis GA, Gijsen AP, Senden JM, LJ VANL. Protein ingestion before sleep improves postexercise overnight recovery. Med Sci Sports Exerc 2012;44:1560-9.

28. Goodpaster B, Kelley D, Thaete F, He J, Ross R. Skeletal muscle attenuation determined by computed tomography is associated with skeletal muscle lipid content. Journal of applied physiology (Bethesda, Md : 1985) 2000;89:104-10.

29. Strandberg S, Wretling M-L, Wredmark T, Shalabi A. Reliability of computed tomography measurements in assessment of thigh muscle cross-sectional area and attenuation. BMC medical imaging 2010;10:18.

30. Bergstrom J. Percutaneous needle biopsy of skeletal muscle in physiological and clinical research. Scand J Clin Lab Invest 1975;35:609-16.

31. Mayhew JL, Prinster JL, Ware JS, Zimmer DL, Arabas JR, Bemben MG. Muscular endurance repetitions to predict bench press strength in men of different training levels. J Sports Med Phys Fitness 1995;35:10813.

32. Verdijk LB, van Loon L, Meijer K, Savelberg HH. One-repetition maximum strength test represents a valid means to assess leg strength in vivo in humans. J Sports Sci 2009;27:59-68.

33. Snijders T, Wall BT, Dirks ML, Senden JM, Hartgens F, Dolmans J, Losen M, Verdijk LB, van Loon LJ. Muscle disuse atrophy is not accompanied by changes in skeletal muscle satellite cell content. Clin Sci (Lond) 2014;126:557-66.

34. Nilwik R, Snijders T, Leenders M, Groen BB, van Kranenburg J, Verdijk LB, van Loon LJ. The decline in skeletal muscle mass with aging is mainly attributed to a reduction in type II muscle fiber size. Exp Gerontol 2013;48:492-8.

35. Kosek DJ, Kim JS, Petrella JK, Cross JM, Bamman MM. Efficacy of 3 days/wk resistance training on myofiber hypertrophy and myogenic mechanisms in young vs. older adults. J Appl Physiol 2006;101:53144.

36. Mackey AL, Holm L, Reitelseder S, Pedersen TG, Doessing S, Kadi F, Kjaer M. Myogenic response of human skeletal muscle to 12 weeks of resistance training at light loading intensity. Scand J Med Sci Sports 2011;21:773-82.

37. Verdijk LB, Snijders T, Beelen M, Savelberg HH, Meijer K, Kuipers H, Van Loon L. Characteristics of muscle fiber type are predictive of skeletal muscle mass and strength in elderly men. J Am Geriatr Soc;58:2069-75. 


\title{
CHAPTER 9
}

\section{Changes in myonuclear domain size do not precede muscle fiber hypertrophy during prolonged resistance type exercise training in healthy young men}

\author{
Tim Snijders \\ Joey S.J. Smeets \\ Janneau van Kranenburg \\ Luc J.C. van Loon \\ Lex B. Verdijk
}

Manuscript prepared for submission 


\section{ABstract}

Introduction: Muscle fiber hypertrophy is accompanied by an increase in myonuclear number, myonuclear domain size, or both. Though an initial increase in myonuclear domain size has been suggested to be a crucial factor driving subsequent myonuclear accretion, there is a lack of data from prolonged exercise training in humans to corroborate this view. In this study we assessed the changes in muscle fiber size, myonuclear and satellite cell contents at regular time points during 12 wks of resistance type exercise training in healthy young men.

Methods: Forty-four healthy young men $(22 \pm 1$ y) were randomly assigned to a progressive, 12-wk resistance type exercise training program (3 sessions/wk) with or without protein supplementation. Muscle biopsies from the vastus lateralis muscle were taken before and after 2, 4, 8 and 12 wks of the exercise training program. Type I and type II muscle fiber size, myonuclear content, myonuclear domain size, and satellite cell content were assessed by immunohistochemistry.

Results: Type I and type II muscle fiber size increased gradually in response 12 wks of resistance type exercise training. Myonuclear content increased significantly over time in type I $(P<0.01)$ and type II $(P<0.001)$ muscle fibers. No changes in type I and type II myonuclear domain size were observed at any time point throughout the training program. Muscle fiber satellite cell content tended to increase over time in type I $(P=0.064)$ and increased significantly in type II $(P<0.001)$ muscle fibers.

Conclusion: A temporary increase in myonuclear domain size does not drive myonuclear accretion during extensive resistance type exercise training induced muscle fiber hypertrophy. 


\section{INTRODUCTION}

Skeletal muscle fibers contain hundreds of myonuclei, and it is generally believed that each myonucleus controls the gene expression and protein synthesis over a certain amount of cytoplasm, referred to as the DNA-unit or myonuclear domain (4). Hence, changes in muscle fiber size should be accompanied by changes in myonuclear domain size, myonuclear number, or a combination of both. As myonuclei are post-mitotic, an increase in myonuclear content must be facilitated by a pool of myogenic precursor cells, also known as skeletal muscle satellite cells. In adult muscle, these satellite cells reside in a niche positioned beneath the basal lamina of their associated muscle fiber and normally remain in a quiescent state. However, upon perturbation satellite cells can become activated after which they are able to proliferate, and subsequently differentiate to form new myonuclei, or return to a quiescent state to replenish the resident pool of satellite cells.

Whether myonuclear accretion is an obligatory step in the process of muscle fiber hypertrophy is a highly debated topic (14). Previous animal studies have shown that muscle fiber growth is attenuated or even prevented after gamma-irradiation, which abolishes the potential of any cell division, including that of satellite cells (18-20). In contrast, more recent animal studies have reported that under specific experimental conditions, muscle fiber hypertrophy is possible without satellite cell induced addition of new myonuclei $(10,14)$. Though some of the latest transgenic animal studies demonstrate that the addition of new myonuclei is not required to allow post-natal muscle fiber growth $(10,14)$ this unlikely translates to an in vivo human model, e.g. during exercise induced muscle hypertrophy. In human skeletal muscle, exercise induced muscle fiber hypertrophy has been shown to be accompanied by myonuclear accretion ( 9 , $11,16)$. In contrast, others have failed to show an increase in myonuclear content following prolonged exercise training in healthy young and elderly men $(7,8,15,16,23$, 26). To explain this discrepancy it has been hypothesized that in a physiological situation, such as in response to prolonged resistance type exercise training, two distinct phases of muscle fiber hypertrophy may exist $(7,8,16,17)$. This "two-phase model" proposes that in response to exercise training, muscle fiber hypertrophy is initially supported by an increase in myonuclear domain size. However, it is thought that the existing myonuclei can only support the underlying increase in transcriptional activity to a certain extent $(8,17)$. Subsequently, the incorporation of new myonuclei may be required to allow more extensive long-term muscle fiber growth. In other words, an initial (temporary) increase in myonuclear domain size has been hypothesized to be a crucial driving force for subsequent myonuclear accretion in response to prolonged resistance type exercise training. However, in humans there is only limited data on the time dependent changes in myonuclear domain size and myonuclear/satellite cell content during prolonged resistance type exercise training induced muscle fiber hypertrophy. In the present study, we aimed to gain further insight in the timeline and underlying pro- 
cesses of muscle fiber hypertrophy in response to traditional resistance type exercise training. Therefore, we assessed type I and type II muscle fiber size, myonuclear content, myonuclear domain size, and satellite cell content in muscle biopsies taken before and after 2, 4, 8, and 12 weeks of resistance type exercise training in healthy young men.

\section{Methods}

\section{Subjects}

Forty-four healthy young men were recruited to participate in a $12 \mathrm{wk}$ resistance type exercise intervention program, with or without additional protein supplementation. This study is part of a greater research project investigating the benefits of protein supplementation on skeletal muscle mass and strength gains in response to resistance type exercise training. Participants were included in an age range of 18-30 y. During an initial screening visit medical history was evaluated, and a blood sample was taken to assess blood $\mathrm{HbA} 1 \mathrm{c}$ and fasting plasma glucose levels. Participants were excluded when $\mathrm{HbA} 1 \mathrm{C}$ levels exceeded $6.5 \%$ or fasted plasma glucose levels were higher than 7 $\mathrm{mmol} / \mathrm{L}$. All subjects were recreationally active, performing sports on a noncompetitive basis between 2 and 5 hours per week. None of the participants had a history of participating in a structured resistance type exercise training program over the past $2 \mathrm{y}$. During the intervention period a total of three participants dropped out, one because of a road accident, one because of pneumonia and one because he underestimated the time required to participate. All subjects were informed on the nature and possible risk of the experimental procedures before their written informed consent was obtained. This study was approved by the Medical Ethics Committee of Maastricht University Medical Centre, and complied with the guidelines set out in the Declaration of Helsinki.

\section{Exercise intervention program}

Supervised resistance type exercise was performed three times a week for a $12 \mathrm{wk}$ period. All training sessions were performed in the evening between 8.00-9.00 pm or 9.00-10.00 pm. During the first week of the training period, the workload was gradually increased from $70 \%$ (10-15 repetitions) of $1 \mathrm{RM}$ to $80 \%$ of $1 \mathrm{RM}$ (8-10 repetitions). Thereafter, training was always performed at $80 \% 1 \mathrm{RM}$. Workload intensity was adjusted based on the 1-RM tests (performed at weeks 4 and 8). In addition, workload was increased when more than eight repetitions could be performed in three of four sets. Training consisted of a 5 min warm-up on a cycle ergometer, followed by four sets on both leg press and leg extension machines (Technogym, Rotterdam, the Netherlands); these two exercise were performed every training session. Two sets on the chest press and horizontal row were alternated with two sets on the vertical pull-down and shoul- 
der press between every training session. Resting periods of 1.5 and 3 min were allowed between sets and exercises, respectively. Each session ended with a 5-min cooling down period on the cycle ergometer.

\section{Dietary protein supplementation}

Throughout the $12 \mathrm{wk}$ intervention period, subjects consumed a $300 \mathrm{~mL}$ of a placebo (placebo group, PLA) or protein drink (protein group, PRO) daily before going to sleep. The protein beverage contained $13.75 \mathrm{~g}$ casein hydrolysate (Peptopro, DSM, Delft, the Netherlands), $13.75 \mathrm{~g}$ intact casein, $15 \mathrm{~g}$ carbohydrate (Sucrose, Suikerunie, the Netherlands) and $0.1 \mathrm{~g}$ fat (DSM, Delft, the Netherlands), providing a total of $746 \mathrm{~kJ}$. The control drink was a non-caloric placebo beverage. Beverages were masked for taste and smell by adding citric acid and vanilla flavour. In addition, beverages were masked for color by adding titanium dioxide (E171) to the placebo drink. Placebo and protein drinks were provided in a randomized, double-blind manner.

\section{Muscle biopsy sampling}

Seven days before the onset of the intervention and after 2, 4, 8 and 12 wk of intervention, muscle biopsies were taken from the right leg of each subject in the morning after an overnight fast. During the resistance type exercise training period (at 2, 4 and 8 week of training) the exercise session planned 4 days prior to muscle biopsy collection was not performed, to prevent any acute effect of the last exercise bout. After local anesthesia was induced in the skin, percutaneous needle biopsy samples (50-80 mg) were collected from the vastus lateralis muscle, approximately $15 \mathrm{~cm}$ above the patella (1). Any visible non-muscle tissue was removed immediately, and biopsy samples were embedded in Tissue-Tek (Sakura Finetek, Zoeterwoude, the Netherlands), frozen in liquid nitrogen-cooled isopentane, and stored at $-80^{\circ} \mathrm{C}$ until further analyses.

\section{Immunohistochemistry}

Frozen muscle biopsies were cut into $5 \mu \mathrm{m}$ thick cryosections using a cryostat at $-20^{\circ} \mathrm{C}$, and thaw mounted on uncoated pre-cleaned glass slides. Samples from baseline and after 2, 4, 8 and 12 weeks of resistance type exercise training were mounted together on the same glass slide. Care was taken to properly align the samples for cross-sectional muscle fiber analyses. Muscle cross-sections were stained with antibodies against laminin (polyclonal rabbit anti-laminin, dilution 1:50; Sigma, Zwijndrecht, the Netherlands), myosin heavy chain (MHC)-I (A4.840, dilution 1:25; Developmental Studies Hybridoma Bank, lowa City, IA), and CD56 (dilution 1:40, BD Biosciences, San Jose, CA). Appropriate secondary antibodies were applied: goat anti-rabbit IgG Alexa647, goat anti-mouse IgM Alexa 555, and Streptavidin Alexa 488 (dilution 1:400, 1:500, and 1:200, respectively; Molecular Probes, Invitrogen, Breda, the Netherlands). Nuclei were stained with 4,6diamidino-2-phenylindole (DAPI, $0.238 \mu \mathrm{M}$; Molecular Probes). Histochemical methods were adapted from previous published methods (21). Images were visualised and au- 
tomatically captured at 10x magnification with a fluorescent microscope equipped with an automatic stage (IX81 motorised inverted microscope, Olympus, Hamburg, Germany), an EXi Aqua CCD camera (QImaging). Micromanager 1.4 software was used for image acquisition (5). Quantitative analyses were done using ImageJ version $1.46 \mathrm{~d}$ software package (version 1.46d, National Institute of Health, MD (22)). The mean fiber cross-sectional area (muscle fiber size), the number of myonuclei per muscle fiber, and the myonuclear domain (i.e. fiber size/number of myonuclei) were determined for type I and type II muscle fibers separately. In addition, the number of satellite cells per muscle fiber, the number of satellite cells per mm squared of muscle fiber, and the number of satellite cells relative to the total number of myonuclei (number of satellite cells / [number of myonuclei + number of satellite cells]*100\%) were also assessed for type I and type II muscle fibers separately. All image recordings and analyses were performed by an investigator blinded to subject coding. Mean numbers of $327 \pm 20,347 \pm 207$, $357 \pm 20,323 \pm 20$ and $323 \pm 20$ muscle fibers were analyzed in the biopsy samples collected prior to and after $2,4,8$ and 12 weeks of resistance type exercise training.

\section{Statistics}

All data are expressed as means \pm SEMs. Baseline characteristics between groups were compared by means of an independent t-test. Because all data were normally distributed, training-induced changes were analyzed with general mixed linear model with time (before after 2, 4, 8, and 12 weeks of exercise training) as a within-subjects factor and treatment (protein compared with placebo) as a between-subjects factor. Partial Pearson correlation coefficients ( $r$, controlled for treatment) were calculated to assess the association between type I or type II muscle fiber hypertrophy, and other muscle fiber characteristics, e.g. baseline and delta (before vs 12 wks) changes in type I and type II muscle fiber myonuclear and satellite cell content, baseline muscle type I and type II muscle fiber size. All analyses were performed by using SPSS version 20.0 (Chicago, IL). An $\alpha$-level of 0.05 was used to determine statistical significance.

\section{RESULTS}

\section{Muscle fiber size}

Muscle fiber size increased significantly over time in both the type I and the type II muscle fibers in response to 12 weeks of resistance type exercise training (Figure 1A-B; main effect of time in type I muscle fibers: $P<0.01$, and type II muscle fibers: $P<0.001)$. Type I muscle fiber size had increased significantly after 4 (placebo: $+5 \pm 5 \%$, protein: $+12 \pm 6 \%$ ), 8 (placebo: $+9 \pm 6 \%$, protein: $+7 \pm 4 \%$ ) and 12 (placebo: $+6 \pm 5 \%$, protein: $+18 \pm 5 \%$ ) weeks of resistance type exercise training (Figure $1 \mathrm{~A}$ ). In addition, we observed a significant increase in type II muscle fiber size after 2 (placebo: $+6 \pm 5 \%$, protein: $+18 \pm 5 \%$ ), 4 (placebo: $+15 \pm 5 \%$, protein: $+19 \pm 6 \%$ ), 8 (placebo: $+25 \pm 5 \%$, protein: 
$+27 \pm 6 \%$ ), and 12 (placebo: $+19 \pm 6 \%$, protein: $+41 \pm 6 \%$ ) weeks of resistance type exercise training (Figure 1B). No significant differences were observed in the increase in type I and type II muscle fiber size between the two groups over all 5 time points (time $x$ treatment interaction for type I muscle fiber size: $P=0.588$, and for type II muscle fiber size: $P=0.105)$.
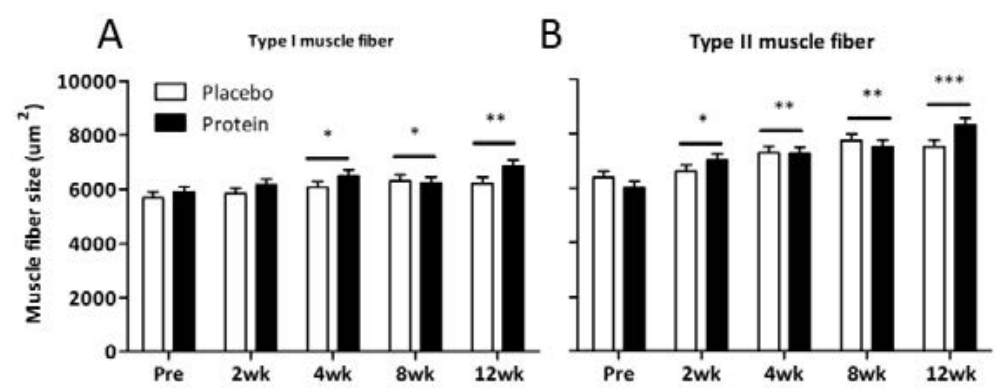

Figure 1 Mean $( \pm S E M)$ muscle fiber size for type I (A) and type II (B) muscle fibers before and after $2,4,8$ and 12 wks of resistance type exercise training in healthy young men with (protein group; $n$ $=20$ ) or without (placebo group; $\mathrm{n}=19$ ) protein supplementation. ${ }^{*}$ significantly different compared with pre-exercise values $(\mathrm{P}<0.05) ;{ }^{* *}$ significantly different compared with pre and 2 wks after exercise $(\mathrm{P}<0.05) ; * * *$ significantly different compared with pre, 2 , and 4 wks after exercise $(\mathrm{P}<0.05)$.

\section{Myonuclear content and domain size}

In response to the resistance type exercise training program type I and type II myonuclear content increased significantly over time (Figure 2A-B; main effect of time in type I muscle fibers: $P<0.01$, and in type II muscle fibers: $P<0.001)$. Type I muscle fiber myonuclear content was significantly increased at 8 and 12 weeks of resistance type exercise training (Figure 2A). Furthermore, we observed a significant increase in the number of myonuclei per type II muscle fiber at 4, 8 and 12 weeks of exercise training (Figure 2B). No significant differences in the increases in type I and type II muscle fiber myonuclear content were observed between the placebo and protein group. No significant changes in type I and type II myonuclear domain size were observed at any time point in both the placebo and protein group (Figure 2C-D; main effect of time $P=0.491$ and $P=0.326$ for type I and type II fibers, respectively). 

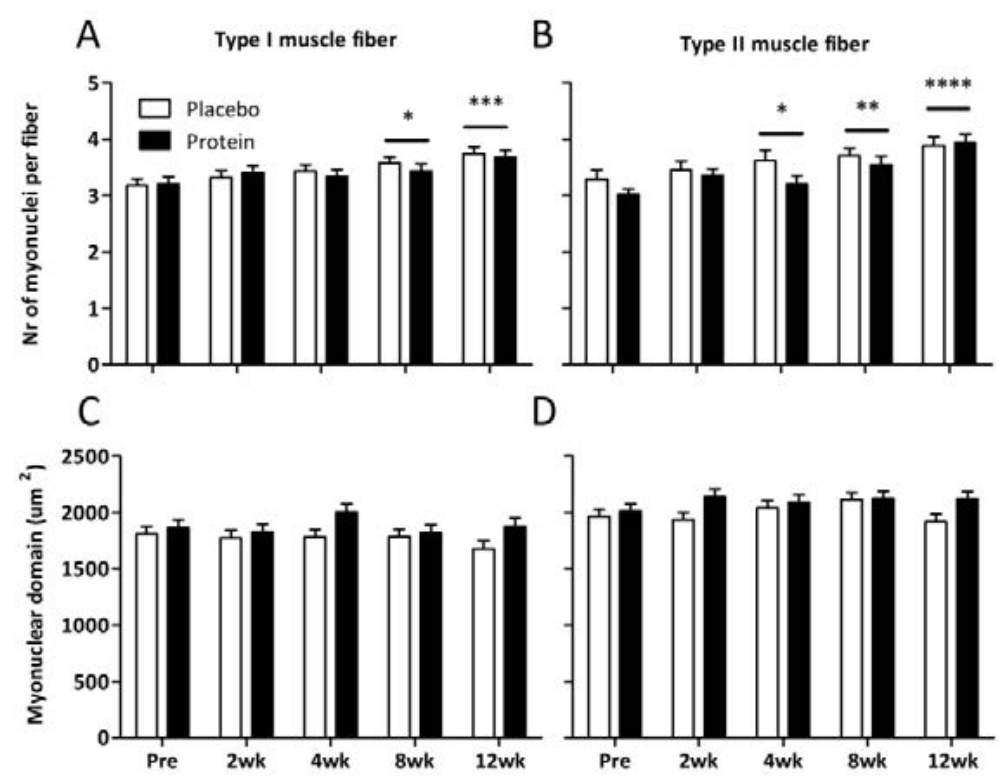

Figure 2 Mean $( \pm$ SEM) number of myonuclei $(A-B)$ and myonuclear domain size (C-D) for type I and II muscle fibers before and after 2, 4, 8 and 12 wks of resistance type exercise training in healthy young men with (protein group; $n=20$ ) or without (placebo group; $n=19$ ) protein supplementation. * significantly different compared with pre-exercise values $(P<0.05)$; ${ }^{* *}$ significantly different compared with pre and 2 wks after exercise $(P<0.05) ; * * *$ significantly different compared with pre, 2 and 4 wks after exercise $(P<0.05) ; * * * *$ : significantly different compared with pre, 2,4 and 8 wks after exercise $(P<0.05)$.

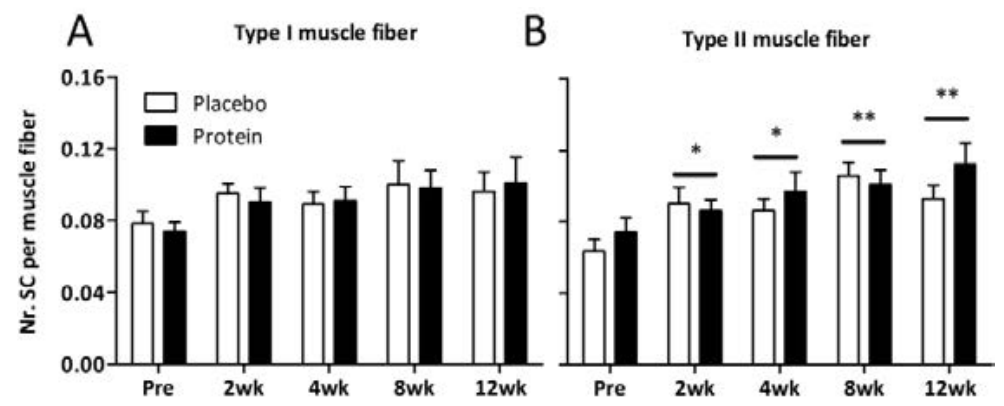

Figure 3 Mean ( \pm SEM) number of satellite cells (SC) per type I (A) and type II (B) muscle fiber before and after 2, 4, 8 and 12 wks of resistance type exercise training in healthy young men with (protein group; $\mathrm{n}=20$ ) or without (placebo group; $\mathrm{n}=19$ ) protein supplementation. * significantly different compared with pre-exercise values $(P<0.05) ; * *$ significantly different compared with pre and 2 wks after exercise $(P<0.05)$. 


\section{Satellite cell content}

The number of satellite cells per type I muscle fiber tended to increase after resistance type exercise training (Figure $3 \mathrm{~A}$; main effect of time $P=0.064$ ). In addition, we observed a robust increase in type II muscle fiber satellite cell contents after exercise training (Figure $3 b$; main effect of time $P<0.0001$ ). Compared with baseline values, type II muscle fiber satellite cell contents were significantly increased at 2, 4, 8 and 12 weeks of exercise training, with no differences between the placebo and protein group (Figure $3 \mathrm{~B}$; time $\mathrm{x}$ treatment interaction $P=0.460$ ). In contrast, the number of satellite cells per $\mathrm{mm}$ squared did not change over time in the type I and type II muscle fibers in both groups (Table 1).

Table 1 Type I and type II muscle fiber satellite cell content

\begin{tabular}{|c|c|c|c|c|c|}
\hline & Pre & 2 & 4 & 8 & 12 \\
\hline \multicolumn{6}{|c|}{ Type I satellite cell/myonuclei (\%) } \\
\hline Placebo & $2.5 \pm 0.3$ & $3.0 \pm 0.3$ & $2.7 \pm 0.3$ & $2.8 \pm 0.3$ & $2.6 \pm 0.3$ \\
\hline Protein & $2.0 \pm 0.2$ & $2.7 \pm 0.2$ & $2.4 \pm 0.2$ & $2.9 \pm 0.2^{*}$ & $2.5 \pm 0.2^{*}$ \\
\hline \multicolumn{6}{|c|}{ Type II satellite cell/myonuclei (\%) } \\
\hline Placebo & $2.4 \pm 0.3$ & $2.7 \pm 0.3$ & $2.7 \pm 0.3$ & $2.9 \pm 0.3$ & $2.3 \pm 0.3$ \\
\hline Protein & $2.5 \pm 0.2$ & $2.6 \pm 0.2$ & $2.7 \pm 0.2$ & $3.0 \pm 0.2^{*}$ & $3.0 \pm 0.2^{*}$ \\
\hline \multicolumn{6}{|c|}{ Type I satellite cell $/ \mathrm{mm}^{2}$} \\
\hline Placebo & $14.0 \pm 1.6$ & $17.2 \pm 1.5$ & $15.6 \pm 1.5$ & $16.5 \pm 1.5$ & $16.5 \pm 1.6$ \\
\hline Protein & $10.2 \pm 1.1$ & $14.1 \pm 1.1$ & $12.2 \pm 1.1$ & $14.1 \pm 1.1$ & $12.7 \pm 1.2$ \\
\hline \multicolumn{6}{|c|}{ Type II satellite cell/mm² } \\
\hline Placebo & $13.1 \pm 1.6$ & $15.0 \pm 1.6$ & $15.1 \pm 1.6$ & $16.1 \pm 1.7$ & $15.1 \pm 1.6$ \\
\hline Protein & $12.6 \pm 1.5$ & $12.4 \pm 1.2$ & $13.4 \pm 1.2$ & $14.0 \pm 1.2$ & $13.8 \pm 1.2$ \\
\hline
\end{tabular}

Data represent means \pm SEM. Satellite cell/myonuclei (\%), the number of satellite cells expressed as a percentage of the total number of myonuclei (i.e. number of myonuclei + number of SCs). * Significantly different compared with pre exercise values $(P<0.05)$.

\section{Partial Pearson correlations}

For the type I muscle fibers, no significant correlations were observed between baseline characteristics and the increase in muscle fiber size (Table 2). In contrast, greater type II muscle fiber size and myonuclear content at baseline were associated with a smaller increase in type II muscle fiber size after 12 weeks of resistance type exercise training (Table 2; baseline type II muscle fiber size: $r=-0.47, P<0.01$, baseline type II myonuclear content: $r=-0.34, P<0.05)$. In addition, for both the type I and type II muscle fibers, a greater increase in the number of myonuclei per fiber was associated with a greater increase in muscle fiber size in response to the training program (Table 2; type I myonuclei per fiber: $r=0.50, P<0.01$, type II myonuclei per fiber: $r=0.45, P<0.01$ ). Finally, specifically for the type II muscle fibers the increase in satellite cell content was also positively correlated with the increase in muscle fiber size (Table $2 ; r=0.35$, $P<0.05)$. 
Table 2 Partial correlations between increase in type I or type II muscle fiber size after 12 wks resistance type exercise training and muscle fiber characteristics

\begin{tabular}{lcc}
\hline & \multicolumn{2}{c}{ Partial Pearson correlations $(\mathrm{r})$} \\
\cline { 2 - 3 } Characteristic & $\begin{array}{c}\Delta \text { type I muscle fiber size } \\
\text { (pre vs 12 wks) }\end{array}$ & $\begin{array}{c}\Delta \text { type II muscle fiber size } \\
\text { (pre vs 12 wks) }\end{array}$ \\
\hline Baseline & 0.43 & $-0.47^{*}$ \\
Muscle fiber size & 0.11 & $-0.34^{*}$ \\
Nuclei/fiber & -0.28 & 0.01 \\
Satellite cells/fiber & & $0.45^{*}$ \\
$\Delta$ Pre vs 12 wks & $0.50^{*}$ & $0.35^{*}$ \\
Nuclei/fiber & 0.16 & \\
Satellite cells/fiber & &
\end{tabular}

Partial Pearson correlations were corrected for treatment group (placebo vs protein). * significant correlation $(P<0.05)$.

\section{Discussion}

In the present study we show that muscle fiber hypertrophy is accompanied by a time dependent increase in myonuclear and satellite cell content in response to 12 weeks of resistance type exercise training in young men. In addition, we show that the exercise training induced muscle fiber hypertrophy is not accompanied by any temporary or permanent increase in myonuclear domain size.

According to the myonuclear domain theory every myonucleus controls a certain amount of cytoplasm, referred to as the myonuclear domain (4). Accordingly, skeletal muscle fiber hypertrophy can be accomplished by a rise in the number of domains (by the incorporation of new myonuclei) or an increase in the size of the existing domains (6). It has been well established that muscle protein synthesis rates are increased for up to 24 to $48 \mathrm{~h}$ after a single bout of resistance type exercise (2). A post-exercise increase in muscle protein synthesis rate indicates that the pre-existing myonuclei have the ability to rapidly respond to the anabolic stimuli by enhancing their transcriptional activity. The cumulative effects of performing repeated bouts of exercise during a more prolonged exercise training program should increase the size of each domain, resulting in fiber hypertrophy. However, such a progressive increase in myonuclear domain size would put the existing myonuclei under progressively more strain. Therefore, it is assumed that additional myonuclei are required to allow more extensive muscle fiber hypertrophy during prolonged exercise training. However, discrepant findings have been reported on the impact of resistance type exercise training induced muscle fiber hypertrophy with respect to changes in myonuclear domain size and, as such, myonuclear accretion. Whereas some studies $(9,16)$ have reported that muscle fiber hypertrophy is accompanied by a substantial rise in myonuclear content, others have failed to detect myonuclear accretion during prolonged resistance type exercise training $(7,8$, 15). To explain this apparent discrepancy it was hypothesized that the myonuclear 
domain size can exceed to a certain threshold (e.g. $\pm 2250 \mu \mathrm{m}^{2}$ ), before the incorporation of new myonuclei becomes prerequisite, also referred to as "ceiling theory" (16, 17). Unfortunately though, most of the data obtained so far are based on the assessment of muscle fiber characteristics before and after cessation of a period of resistance type exercise training $(7,9,16,17)$. Such an approach does not provide any information on the timeline of the events that take place during the gradual process of muscle fiber hypertrophy. The present study is the first to assess whether (temporary) changes in myonuclear domain size may act as a driving factor in the generation and subsequent incorporation of new myonuclei. Therefore, muscle fiber size, myonuclear content, and myonuclear domain size were determined at before and after 2, 4, 8 and 12 weeks of prolonged resistance type exercise training in a large group healthy young males. In the present study we clearly show that both type I and type II muscle fiber hypertrophy are accompanied by a time-dependent increase in myonuclear content throughout 12 weeks of resistance type exercise training (Figure 2A-B). However, we observed no changes in muscle fiber myonuclear domain size at any time point during the resistance type exercise training intervention (Figure 2C-D). In fact, nothing was observed to be as stable as myonuclear domain size over the entire 12 week training period. Interestingly, a significant positive correlation was observed between the increase in myonuclear content and the extent of muscle fiber hypertrophy in both the type I $(r=0.50 ; P<0.05)$ and type II $(r=0.45 ; P<0.05)$ muscle fibers in response to the exercise training program. Together, these data show that substantial increases in myonuclear domain size are not warranted for the generation of new myonuclei in support of extensive muscle fiber hypertrophy during resistance type exercise training.

Previously, we have shown that protein supplementation augments the increase in muscle fiber size in response to prolonged resistance type exercise training (Chapter 8). In agreement with the observed greater gains in leg muscle mass and leg muscle cross sectional are, we report that type II muscle fiber hypertrophy is more than two fold greater in the protein $(+41 \pm 6 \%)$ compared with the placebo supplemented group $(+19 \pm 6 \%)$ following 12 wks of resistance type exercise training. However, when all five time points were included in a single ANOVA analysis time $x$ treatment interaction no longer reached statistical significance $(P=0.105)$. Besides the ceiling theory which suggests an absolute threshold for myonuclear domain size $(16,17)$, others have speculated that it is the relative extent of muscle fiber hypertrophy that should exceed a certain threshold $( \pm 26 \%)$ before the incorporation of new myonuclei can become evident (8). Our data do not seem to support that rational as the observed increases in type II muscle fiber size in the protein and placebo group (i.e. 41 vs 19\%) were achieved by incorporating new myonuclei (Figure 2). Likewise, myonuclear domain size remained unchanged in both groups throughout the 12 weeks of training. As such, our findings do not support the suggestion that muscle fiber hypertrophy should exceed a certain absolute or relative threshold to elicit myonuclear accretion.

As myonuclei are post-mitotic, exercise training induced myonuclear accretion is de- 
pendent on a pool of myogenic precursor cells, also known as skeletal muscle satellite cells. Though satellite cells typically reside in quiescent state, they are able to become active following anabolic stimuli and/or muscle fiber damage. Following activation, satellite cells can proliferate and differentiate to supply new myonuclei, or return to a quiescent state to replenish the resident satellite cell pool. Discrepant ideas have been reported using animal work, as some studies (18-20) report that satellite cell activation, proliferation, and differentiation are essential to allow post-natal muscle fiber growth whereas other has failed to observe any evidence for the requirement of satellite cells to allow hypertrophy to occur $(10,14)$. In the present study, we show that muscle fiber hypertrophy is accompanied by a time-dependent increase in satellite cell content during resistance type exercise training. These results confirm previous observations in human skeletal muscle $(3,8,9,12,13,15-17,23,26)$. It has been suggested that myogenic potential may, in part, be determined by the number of satellite cells present at baseline (17). Here, we did not observe any significant correlation between satellite cell content at baseline and the increase in type I and/or type II muscle fiber size in response to prolonged resistance type exercise training (Table 2), which is consistent with previous work from our laboratory $(24,25)$. However, we do report a significant (albeit weak) positive correlation $(r=0.35, P<0.05)$ between the increase in type II muscle fiber satellite cell content and the extent of type II muscle fiber hypertrophy after 12 weeks of resistance type exercise training (Table 2). These data support the hypothesis that an increase in satellite cell pool size represents an important supportive factor in the process of muscle fiber hypertrophy to resistance type exercise training in vivo in humans. In conclusion, resistance type exercise training induced muscle fiber hypertrophy is accompanied by a time-dependent increase in myonuclear and satellite cell content. Myonuclear domain size does not change throughout prolonged resistance type exercise training and, as such, does not seem to be required to elicit myonuclear accretion and support subsequent muscle hypertrophy in healthy young males. 


\section{References}

1. Bergstrom J. Percutaneous needle biopsy of skeletal muscle in physiological and clinical research. Scand J Clin Lab Invest 35: 609-616, 1975.

2. Burd N, Tang J, Moore D, and Phillips S. Exercise training and protein metabolism: influences of contraction, protein intake, and sex-based differences. Journal of applied physiology (Bethesda, Md : 1985) 106: 1692-1701, 2009.

3. Charifi N, Kadi F, Feasson L, and Denis C. Effects of endurance training on satellite cell frequency in skeletal muscle of old men. Muscle Nerve 28: 87-92, 2003.

4. Cheek DB. The control of cell mass and replication. The DNA unit--a personal 20-year study. Early Hum Dev 12: 211-239, 1985.

5. Edelstein A, Amodaj N, Hoover K, Vale R, and Stuurman N. Computer control of microscopes using microManager. Curr Protoc Mol Biol Chapter 14: Unit14 20, 2010.

6. Edgerton VR, and Roy RR. Regulation of skeletal muscle fiber size, shape and function. J Biomech 24 Suppl 1: 123-133, 1991.

7. Hikida R, Walsh S, Barylski N, Campo G, Hagerman F.Staron R. Is hypertrophy limited in elderly muscle fibers? A comparison of elderly and young strength-trained men. Basic Appl Myol 8: 419-427, 1998.

8. Kadi F, Schjerling P, Andersen LL, Charifi N, Madsen JL, Christensen LR, and Andersen JL. The effects of heavy resistance training and detraining on satellite cells in human skeletal muscles. J Physiol 558: 10051012, 2004.

9. Kadi F, and Thornell LE. Concomitant increases in myonuclear and satellite cell content in female trapezius muscle following strength training. Histochem Cell Biol 113: 99-103, 2000.

10. Lee SJ, Huynh TV, Lee YS, Sebald SM, Wilcox-Adelman SA, Iwamori N, Lepper C, et al. Role of satellite cells versus myofibers in muscle hypertrophy induced by inhibition of the myostatin/activin signaling pathway. Proc Natl Acad Sci U S A 109: E2353-2360, 2012.

11. Leenders M, Verdijk L, van der Hoeven L, van Kranenburg J, Nilwik R, and van Loon L. Elderly men and women benefit equally from prolonged resistance-type exercise training. The journals of gerontology Series A, Biological sciences and medical sciences 68: 769-779, 2013.

12. Mackey AL, Esmarck B, Kadi F, Koskinen SO, Kongsgaard M, Sylvestersen A, Hansen JJ, et al. Enhanced satellite cell proliferation with resistance training in elderly men and women. Scand J Med Sci Sports 17: 34-42, 2007.

13. Mackey AL, Holm L, Reitelseder S, Pedersen TG, Doessing S, Kadi F, and Kjaer M. Myogenic response of human skeletal muscle to 12 weeks of resistance training at light loading intensity. Scand J Med Sci Sports 21: 773-782, 2011.

14. McCarthy JJ, Mula J, Miyazaki M, Erfani R, Garrison K, Farooqui AB, Srikuea R, et al. Effective fiber hypertrophy in satellite cell-depleted skeletal muscle. Development 138: 3657-3666, 2011.

15. Olsen S, Aagaard P, Kadi F, Tufekovic G, Verney J, Olesen JL, Suetta C, et al. Creatine supplementation augments the increase in satellite cell and myonuclei number in human skeletal muscle induced by strength training. J Physiol 573: 525-534, 2006.

16. Petrella JK, Kim JS, Cross JM, Kosek DJ, and Bamman MM. Efficacy of myonuclear addition may explain differential myofiber growth among resistance-trained young and older men and women. Am J Physiol Endocrinol Metab 291: E937-946, 2006.

17. Petrella JK, Kim JS, Mayhew DL, Cross JM, and Bamman MM. Potent myofiber hypertrophy during resistance training in humans is associated with satellite cell-mediated myonuclear addition: a cluster analysis. J Appl Physiol 104: 1736-1742, 2008.

18. Rosenblatt J, and Parry D. Adaptation of rat extensor digitorum longus muscle to gamma irradiation and overload. Pflügers Archiv : European journal of physiology 423: 255-264, 1993.

19. Rosenblatt J, and Parry D. Gamma irradiation prevents compensatory hypertrophy of overloaded mouse extensor digitorum longus muscle. J Appl Physiol 73: 2538-2543, 1992.

20. Rosenblatt J, Yong D, and Parry D. Satellite cell activity is required for hypertrophy of overloaded adult rat muscle. Muscle \& nerve 17: 608-613, 1994. 
21. Snijders T, Wall BT, Dirks ML, Senden JM, Hartgens F, Dolmans J, Losen M, et al. Muscle disuse atrophy is not accompanied by changes in skeletal muscle satellite cell content. Clin Sci (Lond) 126: 557-566, 2014.

22. Strandberg S, Wretling M-L, Wredmark T, and Shalabi A. Reliability of computed tomography measurements in assessment of thigh muscle cross-sectional area and attenuation. BMC medical imaging 10: 18, 2010.

23. Verdijk LB, Gleeson BG, Jonkers RA, Meijer K, Savelberg HH, Dendale P, and van Loon LJ. Skeletal muscle hypertrophy following resistance training is accompanied by a fiber type-specific increase in satellite cell content in elderly men. J Gerontol A Biol Sci Med Sci 64: 332-339, 2009.

24. Verdijk LB, Snijders T, Beelen M, Savelberg HH, Meijer K, Kuipers H, and Van Loon LJ. Characteristics of muscle fiber type are predictive of skeletal muscle mass and strength in elderly men. J Am Geriatr Soc 58: 2069-2075.

25. Verdijk LB, Snijders T, Drost M, Delhaas T, Kadi F, and van Loon $\amalg$. Satellite cells in human skeletal muscle; from birth to old age. Age (Dordr) 2013.

26. Verney J, Kadi F, Charifi N, Feasson L, Saafi MA, Castells J, Piehl-Aulin K, et al. Effects of combined lower body endurance and upper body resistance training on the satellite cell pool in elderly subjects. Muscle Nerve 38: 1147-1154, 2008. 


\section{CHAPTER 10}

General discussion 


\section{General Discussion}

Aging is accompanied by a progressive loss of skeletal muscle mass, also known as sarcopenia. Skeletal muscle satellite cells have been proposed to play a crucial role in muscle fiber maintenance, regeneration and growth. Hence, these satellite cells may be a key factor in both the development and treatment of sarcopenia in later life. In this thesis, we studied the importance of skeletal muscle satellite cells in muscle fiber atrophy and exercise induced muscle fiber hypertrophy. In this final chapter we will address the implications of the presented findings, and discuss them in a broader perspective. Finally, several important aims for future research will be defined.

\section{THE ROLE OF SATELLITE CELLS IN SKELETAL MUSCLE FIBER ATROPHY}

The age-related loss of skeletal muscle mass is characterized by specific type II muscle fiber atrophy (Chapter 1,2 and 6) (31, 33, 52, 53, 57, 62, 86, 94, 122, 124, 125). We (Chapter 2, 6) $(60,122-125)$ as well as others $(22,75,76,112,126)$ have now consistently shown that type II muscle fiber atrophy as observed with aging is accompanied by a reduced satellite cell content in these fibers. Since satellite cells are thought to be important in muscle fiber growth and regeneration, they have been implicated as a key regulator of skeletal muscle mass maintenance throughout life. In mice, it has been shown that the ablation of satellite cells induces a rapid decline in muscle fiber size (105). Furthermore, the muscle fiber type specific decline in satellite cell content has been reported to precede the age-related muscle fiber atrophy in animal muscle (16). Subsequently, it has been hypothesized that an age-related decline in type II muscle fiber satellite cell content leads to an impaired capacity for muscle fiber maintenance, leading to specific type II muscle fiber atrophy that is typically observed in senescent muscle. In line with this hypothesis, we have previously shown that satellite cell content is an important predictor of muscle fiber size in elderly men (125). However, given the cross-sectional nature of the data obtained from studies performed in humans, there is little insight whether a reduction in satellite cell content is indeed causally related to age-related muscle loss. A human research model that has been applied extensively to study the mechanisms underlying skeletal muscle mass loss is limb immobilization. This model allows the assessment of skeletal muscle atrophy in a longitudinal research study design. So far, only few studies have assessed the potential role of satellite cells in the development of (disuse) muscle fiber atrophy in vivo in humans. Satellite cell content has been reported to remain unchanged when muscle fiber atrophy was induced by 5 days or 2 weeks of single legged knee immobilization in both healthy young (Chapter 3$)(22)$ and elderly men $(22,112)$. Interestingly, Suetta et al. (112) even reported a significant increase in the number of satellite cells in both the type I and type II muscle fibers in response to disuse atrophy in healthy young males. Although muscle fiber atrophy induced by short-term disuse is not likely the ideal model to study 
the progressive loss of muscle mass with aging, it does provide insight in the relevance of satellite cell content in the development muscle fiber atrophy. The first results from in vivo human studies, including this thesis, infer that a decline in satellite content is not a mechanistic prerequisite for the development of (short-term) muscle fiber atrophy. In more severe pathological conditions like Duchenne muscular Dystrophy or myotonic dystrophy, it has been hypothesized that the exhaustion of the satellite cell pool may play a major role in the inability to offset degenerative events, resulting in extensive muscle wasting $(29,65)$. However, there are no indications that exhaustion of the satellite cell pool occurs with muscle disuse or healthy aging. Furthermore, the lower satellite cell pool size in type II muscle fiber in senescent muscle does not seem to prevent muscle fiber hypertrophy in healthy elderly men and women in response to prolonged resistance type exercise training (Chapter 2) (61, 123).

Apart from satellite cell content, impairments in the satellite cell responsiveness to anabolic stimuli has also been hypothesized to contribute to the development of agerelated muscle fiber atrophy. Previous in vitro and in vivo animal studies have shown that satellite cell activation is impaired in senescent muscle (24). In agreement, in Chapter 4 of this thesis we conclude that the increase in satellite cell content is delayed in senescent muscle and accompanied by a blunted satellite cell activation response during recovery from a single bout of resistance type exercise. Besides an age-related impaired skeletal muscle adaptive response to exercise, it has been suggested that elderly people experience more difficulties when recovering from short successive periods of muscle disuse. In healthy young males, skeletal muscle mass and strength return back to baseline levels during a few weeks of recovery from a short period of muscle disuse either with $(22,112,113)$ or without (Chapter 3 ) adjuvant rehabilitative exercise training. In contrast, in both animal $(93,134)$ and human models $(22,43,44,112,113)$ it has been demonstrated that senescent muscle does not fully recover from muscle disuse atrophy. In addition, muscle from old animals has been shown to be less responsive to interventional strategies that are known to attenuate disuse atrophy, such as intermittent reloading (35). Impairments in satellite cell function at a more advanced age may contribute to the reduced capacity to recover from disuse atrophy in elderly people (22, 35,112 ). Successive periods of muscle disuse may be responsible for the progressive loss of muscle mass and strength over the lifespan. The inability to fully recover from such events may be the cause of muscle atrophy observed with aging $(32,130,131)$.

Interestingly, recent animal studies have been provided new leads on the potential underlying mechanisms of impaired satellite cell function with advancing age. In animal muscle, it has been demonstrated that satellite cells show a clear increase in DNA damage with age (110). It has been hypothesized that this substantial increase in satellite cell DNA damage is occurring because satellite cell are arrested in an early stage of myogenesis, preventing the satellite cell from completing the cell cycle. A reduction in the systemic levels of Growth Differentiation Factor 11 (GDF11), as observed in aged muscle, has been suggested may be responsible for this marked increase in satellite cell 
DNA damage (110). Remarkable, Sinha et al. (2014) have demonstrated that the administration of recombinant GDF11 for 28 days increases the number of satellite cells with intact DNA, improves muscle fiber regeneration, and increases muscle fiber size and function in aged mice muscle. Similarly, Sousa-Victor et al. (2014) have recently demonstrated that in mice senescent muscle, resting satellite cells lose reversible quiescence due to switching to an irreversible pre-senescence state, caused by the derepression of p16INK4a (111). Together these studies appear to suggest that specific signaling proteins cause a disruption of a satellite cell activation, proliferation and/or differentiation during muscle fiber maintenance, regeneration and/or growth. It would be of a great interest to observe whether the irreversible pre-senescence state of satellite cells in aged muscle may explain the impaired satellite cell function observed during recovery from a single bout of exercise and/or a period of disuse in healthy elderly people. Alleviating a pre-senescent state and/or blunted post-exercise satellite cell activation response in senescent muscle may represent a key target in the development of future intervention strategies to more effectively counteract the progressive loss of muscle mass with aging. Future research should aim to determine the underlying mechanisms on the transition of quiescent satellite cell to their activated state in both young and elderly people in response to an anabolic stimulus. Furthermore, it is important to note that so far most work on the importance of satellite cell function during skeletal muscle recovery has been performed in men. Elderly women may show greater variation in the response to exercise and therefore may have a greater impairment in their myogenic response $(51,52)$. As such, future research should also aim to identify gender related differences related to the role of satellite cells during post-exercise recovery and the progression of sarcopenia.

\section{ARE SATELLITE CELLS ESSENTIAL FOR MUSCLE FIBER HYPERTROPHY?}

During early postnatal development, and throughout childhood growth, extensive muscle fiber growth is accompanied by a concomitant increase in the number of myonuclei $(30,90,120)$. As skeletal muscle satellite cells are the only source to supply new myonuclei, their contribution to muscle fiber growth appears evident. However, whether satellite cells are really essential for muscle fiber hypertrophy in adults remains a topic of great debate. The idea that satellite cells are prerequisite for muscle fiber hypertrophy has been conceptualized by the myonuclear domain theory, which was introduced by Cheek et al. (1965). The myonuclear domain theory proposes that each myonucleus within the muscle fiber controls the gene expression of a certain volume of cytoplasm. Hence, muscle fiber hypertrophy should be accompanied by an increase in myonuclear content, myonuclear domain size, or a combination of both. As myonuclei are postmitotic, myonuclear accretion can only occur through the fusion of satellite cells to the growing muscle fibers, thereby contributing new nuclei $(80,108)$. The first studies to test the hypothesis that satellite cells are essential to allow muscle fiber hypertrophy, 
applied $\gamma$-irradiation to prevent satellite cell activity and, as such, to prevent the incorporation of new myonuclei following overload. These studies show that in satellite cell ablated muscle, muscle fiber growth is virtually non-existing $(1,8,101-103)$. This supported the suggestion that satellite cell proliferation and subsequent myonuclear accretion is required to allow muscle fiber hypertrophy to occur. In agreement, it has been demonstrated that postnatal muscle growth is severely blunted in Pax7 knock-out mice, likely due to the progressive depletion ( $\pm 90 \%)$ of satellite cells during maturation (92). In human skeletal muscle, satellite cell content and activation status has been shown to increase substantially in response to a single bout of resistance type exercise (Chapter 6 and 7$)(7,27,28,31,75,76,85,129)$, eccentric exercise (Chapter 5$)(73,74,79,89,119)$ or a combination of endurance and resistance type exercise (Chapter 4$)$. In addition, we (Chapter 1 and 9) $(60,123)$ as well as others $(94,95,126)$ have shown that an increase in muscle fiber size is accompanied by a substantial rise in myonuclear and satellite cell contents following prolonged resistance and endurance type exercise training. Moreover, Petrella et al. (95) reported that the muscle hypertrophic response to prolonged resistance type exercise training correlates significantly with the amount of satellite cells present in muscle prior to the onset of exercise training in humans. In the work presented in this thesis (Chapter 2 and 9), we did not observe a significant correlation between skeletal muscle satellite cell content prior to exercise training and skeletal muscle hypertrophic response to prolonged training. Despite the absence of such a relation, we did show that a greater increase in type II muscle fiber satellite cell content is accompanied by a greater increase in type II muscle fiber size in healthy elderly men. In line with Petrella et al. $(94,95)$, our results presented in Chapter 2 provide further support for the concept that an increase in satellite cell and myonuclear content must play a permissive role in the skeletal muscle adaptive response to prolonged resistance type exercise training.

The concept that satellite cell addition is required to allow muscle fiber hypertrophy to occur has recently been challenged and has since become a topic of intense debate (11, $42,47,63,66,69,87,88,100)$. Although the early $\gamma$-irradiation studies $(8,101-103)$ were effective in blocking satellite cell proliferation, it was speculated that cellular specificity was poor (70). In an attempt to address this issue McCarthy et al. (70) developed a genetic mouse model to conditionally and specifically ablate satellite cells in skeletal muscle to re-test the hypothesis that satellite cells are required to allow skeletal muscle hypertrophy. Their study showed that in normal, non-satellite cell-depleted muscle (i.e. sham condition), overload induced muscle fiber hypertrophy is accompanied by the fusion of satellite cell-derived myonuclei (70). However, muscle fiber growth was similar in the tamoxifen condition, in which the muscle was virtually depleted from satellite cells. Based on these results the authors concluded that satellite cells are not essential to allow muscle fiber hypertrophy to occur in mice muscle. However, muscle fiber regeneration was severely compromised in the satellite cell depleted muscle tissue. This implies that satellite cells may not be required to allow some level of 
hypertrophy to occur, but that satellite cells are essential for the formation of new muscle fibers and fiber regeneration (70). In addition, others $(58,132)$ have shown that the pharmacological blockage of the myostatin/Activin A pathway induces muscle fiber hypertrophy without satellite cell activation and with little to no fusion of satellite cells to existing muscle fibers. Together, these data suggest that under specific experimental conditions $(4,10,59,70,106,132)$ the existing myonuclei have the intrinsic capacity to increase their governing domain to such an extent that additional myonuclei are not prerequisite to allow muscle hypertrophy. However, Fry et al. (2014) has recently demonstrated that in satellite cell depleted muscle, the existing myonuclei are only able to support overload induced muscle fiber hypertrophy up to a certain extent. This study in mice shows that after a prolonged period (8 weeks) of overload, muscle fiber hypertrophy is compromised in satellite cell depleted muscle tissue (34). Mechanistic studies in animal models are required to see whether extensive muscle fiber hypertrophy can be induced in transgenic models displaying dramatic defects in satellite cell pool size and/or function. However, such research should be evaluated with some restraint as satellite cell ablated muscle does not represent a normal physiological situation. In addition, obvious differences in myonuclear and satellite cell contents have been show to exist between species, complicating the translation of these animal studies to an in vivo human setting $(13,15)$.

Most in vivo human studies are mainly descriptive, showing correlations between changes in myonuclear content, satellite cell number, and muscle fiber size in response to an anabolic stimulus. Nonetheless, such studies are crucial in understanding the role of satellite cell content and function in skeletal muscle fiber hypertrophy in an in vivo human setting. It has been hypothesized that skeletal muscle hypertrophy may occur in a series of specific stages. In a first response to exercise training muscle fibers can increase muscle protein synthesis allowing some level of hypertrophy with an accompanying increase in myonuclear domain size. However, at some stage a threshold in myonuclear domain will be achieved after which further hypertrophy can only occur after myonuclear accretion $(48,87,103,104)$. For human muscle tissue, it has been proposed that when myonuclear domain size increases beyond $2000-2500 \mu \mathrm{m}^{2}$ more extensive hypertrophy requires myonuclear accretion. In Chapter 9 of this thesis we describe the changes in type I and type II muscle fiber size, myonuclear content, domain size and satellite cell content at regular time points during 12 weeks of resistance type exercise training in healthy young men. In line with previous study results we show that exercise training induces muscle fiber hypertrophy and that this hypertrophy is accompanied by a significant increase in myonuclear and satellite cell content. Despite the fact that we collected muscle biopsy samples before and after 2, 4, 8 and 12 weeks of resistance type exercise training in healthy young men, there was no apparent change in myonuclear domain size (Chapter 9). This leaves us with the question, what factor(s) trigger satellite cell activation, proliferation and differentiation to allow such a wellorchestrated maintenance of myonuclear domain size. It could be speculated that local 
contraction induced factors released in the immediate proximity of the satellite cell niche are essential in satellite cell activation response to an anabolic stimuli. Previously is has been reported that the release of growth factors like hepatocyte growth factor (HGF) $(115,116)$, insulin-like growth factor I (IGF1) (96), basis fibroblast growth factor (bFGF) (121), fibroblast growth factor (FGF) (3) and mechano-growth factor (MGF) (67) are able to activate satellite cells in response to muscle fiber damage. In addition, within the niche of the satellite cell, signaling proteins like myostatin, Wnt and Notch have been demonstrated to play key roles in the process of satellite cell activation, proliferation and/or differentiation to allow myonuclear accretion to facilitate muscle fiber regeneration $(25,40,64,91)$. In the more systemic environment, pro-inflammatory cytokines like IL1, IL6 and TNF- $\alpha$ have also been shown to influence satellite cell function $(5,23)$. Though numerous studies have assessed the structural and biochemical cues for satellite cell activation in in vitro cell and/or in vivo animal models of muscle fiber regeneration, little is known to what extent these factors influence satellite cell activation, proliferation and/or differentiation in vivo in humans during skeletal muscle fiber hypertrophy. Hence, we need to design in vivo human studies to identify which factors trigger the transition of satellite cells from quiescent to their activated state in response to an anabolic stimulus. Such studies will provide critical insight in the regulation of myonuclear accretion and myonuclear domain size during extensive muscle fiber hypertrophy within the myonuclear domain paradigm. In addition, as impairments in satellite cell activation are thought to be responsible for a blunted skeletal muscle fiber hypertrophy response after training exercise in healthy and/or more compromised elderly people, the identification of the specific triggers of satellite cell activation will also proof to be paramount in the development of novel intervention strategies to more effectively combat the age-related loss of skeletal muscle mass.

\section{MYOSTATIN, MASTER REGULATOR OF MUSCLE PLASTICITY}

Myostatin is a member of the transforming growth factor- $\beta$ (TGF- $\beta$ ) superfamily and acts as a strong negative regulator of skeletal muscle growth. Myostatin is predominately expressed in skeletal muscle, although cardiac muscle and adipose tissue have also been reported to express it in low levels $(77,78)$. McPherron et al. $(77)$ were the first to characterize the phenotypic response to myostatin gene mutation in mice. In this study they showed that inhibition or mutation of the myostatin gene resulted in mice that exhibited an amount of muscle mass that was typically 2-3 fold greater when compared with wild-type mice. This initial study was soon followed by other publications showing that naturally occurring myostatin mutations are accompanied by excessive muscle fiber hypertrophy/hyperplasia as observed in double-muscled cattle, sheep, and dogs $(38,49)$. In humans, Schuelke et al. (109) reported a single case study in which a new born child was identified as a carrier of a myostatin null mutation, after being noted to have an unusual high level of muscle mass at birth. Apart from the increased 
muscle development, the child developed normally, both physiologically and mentally (109). These studies provided the first clues that myostatin might be a strong negative regulator of muscle growth and, as such, myostatin was hypothesized to be a key factor in catabolic disease which may contribute to muscle wasting. In accordance, myostatin levels in serum and/or expression in muscle have been reported to be elevated in animal models of cachexia $(26,136)$, chronic kidney disease (135), glucocorticoid administration (55), burn injury (55), and also during mechanical unloading (21), and spaceflight $(2,54)$. Similar changes in myostatin expression have been observed in patients with cancer (55), HIV/aids (37), $\operatorname{COPD}(41,46,98)$, renal (114), and heart failure $(17,36$, 39). In healthy individuals, myostatin levels and expression in muscle has been demonstrated to increase in response to prolonged bed rest (99), and limb immobilization (Chapter 3). In addition, elderly men and women have been shown to exhibit higher myostatin levels in both the circulation (133) and in skeletal muscle tissue (76) when compared to younger controls. Given the evidence so far, myostatin may play a key regulatory role in the loss of muscle mass with aging.

Multiple mechanistic pathways through which myostatin is able to regulate skeletal muscle growth have already been identified. Myostatin has been demonstrated to induce muscle wasting by acting on the ubiquitin proteolytic system. Ubiquitin associated genes like atrogin-1, FoxO1 and MuRF-1 are upregulated under the action of myostatin (54). A second mechanism by which myostatin may negatively regulate muscle mass is by controlling myogenesis. In vitro, myostatin has been reported to block myoblast proliferation $(117,118)$, and differentiation by the down-regulation of MyoD (56) and upregulation of p21 (72). In addition, myostatin has been demonstrated to inhibit satellite cell activation and self-renewal (71). Interestingly, some $(71,72,127)$, but certainly not all $(4,132)$, studies have shown that satellite cell proliferation and content are significantly higher in muscle tissue from myostatin knock-out compared with wildtype mice. It could be speculated that myostatin plays a critical role in maintaining and/or returning satellite cells in a quiescent state. In accordance, in this thesis (Chapter 6 and 7) we show that in resting conditions 70-80\% of the satellite cells (Pax7+ myonuclei) co-localize with the myostatin protein in both type I and type II muscle fibers in healthy young and elderly men. In the present study we provide further evidence that elderly are less able to down-regulate myostatin in the satellite cell during post exercise recovery compared with the young (Chapter 6). Subsequently, this may, in part, explain the blunted increase in the number of activated satellite cells, and the delay in satellite cell pool expansion in response to a single bout of exercise in the elderly (Chapter 6$)(31,75,76)$. It could be speculated that elderly may need more recovery time after performing an exercise bout to optimize the post-exercise skeletal muscle adaptive response. As such, studies are warranted that assess type I and type II muscle fiber satellite cell content, satellite cell activation status and myostatin expression at longer time interval after a single bout of exercise. Alternatively, it would be interesting to observe whether the performance of a second and/or third bout of exer- 
cise will alleviate the reduced satellite cell activation and/or myostatin response typically observed in healthy elderly men.

All together the current literature suggests that myostatin represents a major factor in the regulation of skeletal muscle mass and function. Though the exact mechanism through which myostatin is able to regulate muscle fiber growth and/or atrophy are still under investigation, myostatin has become a promising new therapeutic target to treat muscle wasting diseases. Myostatin inhibitors have been shown to exhibit positive effects on physical performance, muscle function and muscle mass in animal models of cancer cachexia $(9,14,84,136)$, lung carcinoma (19) muscular dystrophy $(12,83,97)$, unloading (81), and chronic kidney disease (135). In addition, the administration of myostatin inhibitors to aged animals has been demonstrated to increase aerobic exercise performance (135), and attenuate the decline in muscle mass and function (82). In humans, most $(6,20,45)$ but certainly not all $(128)$ phase 1 and 2 trials have shown positive results of myostatin inhibitors on muscle mass and function in healthy young, elderly and/or more compromised clinical patients. It would be of great interest to observe whether the administration of myostatin inhibitors could alleviate the blunted skeletal muscle adaptive response following a single or rather multiple successive bouts of exercise in the elderly. In addition, it would be interesting to investigate whether myostatin inhibitors would enhance the recovery from disuse muscle atrophy observed after bed rest or immobilization. Several clinical trials are currently in progress that specifically investigates the therapeutic properties of myostatin inhibitor administration to increase muscle mass in older, clinically compromised patient groups. Together the results, so far, certainly suggest that inhibiting the myostatin/Activin pathway may be a promising approach to combat the loss of skeletal muscle mass and function during aging. However, whether myostatin truly is the proposed "holy grail" of the aging population (18) remains to be established.

\section{GENERAL CONCLUSIONS AND FUTURE RESEARCH}

Since their discovery in $1961(50,68)$, a great body of scientific research has been devoted to the properties and function of skeletal muscle satellite cells. Research in the last 50 years suggests that skeletal muscle satellite cells are resident muscle stem cells responsible for supplying new myonuclei to support and/or allow skeletal muscle maintenance, hypertrophy and/or repair (107). However, whereas these suggestions are mainly derived from in vitro and animal based research, the properties and function of satellite cells in human skeletal muscle remain relatively unexplored. The work presented in this thesis applied an in vivo human approach to investigate the importance of skeletal muscle satellite cells during muscle fiber atrophy and exercise induced muscle fiber hypertrophy. We provide further evidence that type II muscle fiber atrophy is accompanied by a fiber type specific decline in satellite cell content with aging. Although satellite cell pool size may be an important factor in muscle fiber atrophy as 
observed during aging, we show that a short period of disuse atrophy is not associated with measurable changes in the satellite cell pool size. Subsequently, a decline in satellite cell content does not appear to be a proxy for the development of muscle fiber atrophy.

Furthermore, we have demonstrated that a single bout of exercise represents a potent stimulus to increase satellite cell content in type I and type II muscle fibers in both young and elderly men. However, the increase in satellite cell content is delayed in the elderly men and is accompanied by a blunted satellite cell activation response during the first 72 hours of post-exercise recovery. Healthy elderly men appear to be less able to down-regulate myostatin in satellite cells compared to young controls after a single bout of resistance exercise. Hence, myostatin may be instrumental for the attenuated increase in satellite cell pool expansion, a blunted myogenic response to prolonged exercise training, and the overall development of sarcopenia. The performed experiments have increased our knowledge on the role of satellite cells in muscle fiber adaptation in response to physical (in) activity. However, many questions remain unanswered. Questions that should be addressed in future research include:

- How much time does it take for the satellite pool size to peak in response to a single bout of exercise in both young and elderly men?

- What happens with the satellite cell pool size after a second and/or third bout of resistance type exercise?

- Could the administration of myostatin inhibitors alleviate the blunted recovery of skeletal muscle in elderly after a single bout of exercise and/or a period of disuse?

- Which factor is driving myonuclear accretion during extensive muscle fiber hypertrophy during exercise training?

- How does the increase in satellite cell activation and/or content relate to the postexercise muscle protein synthetic response?

- $\quad$ Are other cell types also able to provide new myonuclei during muscle fiber hypertrophy in response to an anabolic stimulus?

- What is the role of myostatin in muscle plasticity in relation to aging?

- To what extent does myostatin expression determine the muscle adaptive response to prolonged resistance type exercise training?

- Besides supplying additional myonuclei, to what extent do satellite cells contribute to other types of skeletal muscle fiber remodeling? (e.g. muscle fiber type transition).

- Are skeletal muscle satellite cells able to differentiate to other cell types besides myonuclei? 


\section{REFERENCES}

1. Adams G, Caiozzo V, Haddad F, and Baldwin K. Cellular and molecular responses to increased skeletal muscle loading after irradiation. American journal of physiology Cell physiology 283: 95, 2002.

2. Allen D, Bandstra E, Harrison B, Thorng S, Stodieck L, Kostenuik P, Morony S, et al. Effects of spaceflight on murine skeletal muscle gene expression. Journal of applied physiology 106: 582-595, 2009.

3. Allen R, Dodson M, and Luiten L. Regulation of skeletal muscle satellite cell proliferation by bovine pituitary fibroblast growth factor. Experimental cell research 152: 154-160, 1984.

4. Amthor H, Otto A, Vulin A, Rochat A, Dumonceaux J, Garcia L, Mouisel E, et al. Muscle hypertrophy driven by myostatin blockade does not require stem/precursor-cell activity. Proceedings of the National Academy of Sciences of the United States of America 106: 7479-7484, 2009.

5. Anderson J. A role for nitric oxide in muscle repair: nitric oxide-mediated activation of muscle satellite cells. Molecular biology of the cell 11: 1859-1874, 2000.

6. Attie KM, Borgstein NG, Yang Y, Condon $\mathrm{CH}$, Wilson DM, Pearsall AE, Kumar R, et al. A single ascendingdose study of muscle regulator ACE-031 in healthy volunteers. Muscle Nerve 47: 416-423, 2013.

7. Babcock L, Escano M, D'Lugos A, Todd K, Murach K, and Luden N. Concurrent aerobic exercise interferes with the satellite cell response to acute resistance exercise. American journal of physiology Regulatory, integrative and comparative physiology 302: 65, 2012.

8. Barton-Davis ER, Shoturma DI, and Sweeney HL. Contribution of satellite cells to IGF-I induced hypertrophy of skeletal muscle. Acta physiologica Scandinavica 167: 301-305, 1999.

9. Benny Klimek ME, Aydogdu T, Link MJ, Pons M, Koniaris LG, and Zimmers TA. Acute inhibition of myostatin-family proteins preserves skeletal muscle in mouse models of cancer cachexia. Biochem Biophys Res Commun 391: 1548-1554, 2010.

10. Blaauw B, Canato M, Agatea L, Toniolo L, Mammucari C, Masiero E, Abraham R, et al. Inducible activation of Akt increases skeletal muscle mass and force without satellite cell activation. FASEB journal : official publication of the Federation of American Societies for Experimental Biology 23: 3896-3905, 2009.

11. Bodine S. In response to Point:Counterpoint: "Satellite cell addition is/is not obligatory for skeletal muscle hypertrophy". Journal of applied physiology (Bethesda, Md : 1985) 103: 1105-1106, 2007.

12. Bogdanovich S, Krag T, Barton E, Morris L, Whittemore L-A, Ahima R, and Khurana T. Functional improvement of dystrophic muscle by myostatin blockade. Nature 420: 418-421, 2002.

13. Boldrin L, Muntoni F, and Morgan J. Are human and mouse satellite cells really the same? The journal of histochemistry and cytochemistry : official journal of the Histochemistry Society 58: 941-955, 2010.

14. Bonetto A, Penna F, Minero VG, Reffo P, Bonelli G, Baccino FM, and Costelli P. Deacetylase inhibitors modulate the myostatin/follistatin axis without improving cachexia in tumor-bearing mice. Curr Cancer Drug Targets 9: 608-616, 2009.

15. Booth F. Effect of limb immobilization on skeletal muscle. Journal of Applied Physiology 1982.

16. Brack A, Bildsoe $H$, and Hughes S. Evidence that satellite cell decrement contributes to preferential decline in nuclear number from large fibres during murine age-related muscle atrophy. Journal of cell science 118: 4813-4821, 2005.

17. Breitbart A, Auger-Messier M, Molkentin J, and Heineke J. Myostatin from the heart: local and systemic actions in cardiac failure and muscle wasting. American journal of physiology Heart and circulatory physiology 300: 82, 2011.

18. Buehring B, and Binkley N. Myostatin - The Holy Grail for Muscle, Bone, and Fat? Current osteoporosis reports 2013.

19. Busquets S, Toledo M, Orpí M, Massa D, Porta M, Capdevila E, Padilla N, et al. Myostatin blockage using actRIIB antagonism in mice bearing the Lewis lung carcinoma results in the improvement of muscle wasting and physical performance. Journal of cachexia, sarcopenia and muscle 3: 37-43, 2012.

20. Campbell C, Escolar D, Mah J, Tarnopolsky M, Selby K, McMillan H, Yang Y, et al. A Phase 2, Randomized, Placebo-Controlled, Multiple Ascending-Dose Study of ACE-031, a Soluble Activin Receptor Type IIB, in Boys with Duchenne Muscular Dystrophy (DMD). Neurology 78: 2012. 
21. Carlson C, Booth F, and Gordon S. Skeletal muscle myostatin mRNA expression is fiber-type specific and increases during hindlimb unloading. The American journal of physiology 277: 6, 1999.

22. Carlson M, Suetta C, Conboy M, Aagaard P, Mackey A, Kjaer M, and Conboy I. Molecular aging and rejuvenation of human muscle stem cells. EMBO molecular medicine 1: 381-391, 2009.

23. Chazaud B, Sonnet C, Lafuste P, Bassez G, Rimaniol A-C, Poron F, Authier F-J, et al. Satellite cells attract monocytes and use macrophages as a support to escape apoptosis and enhance muscle growth. The Journal of cell biology 163: 1133-1143, 2003.

24. Conboy I, Conboy M, Smythe G, and Rando T. Notch-mediated restoration of regenerative potential to aged muscle. Science (New York, NY) 302: 1575-1577, 2003.

25. Conboy I, and Rando T. The regulation of Notch signaling controls satellite cell activation and cell fate determination in postnatal myogenesis. Developmental cell 3: 397-409, 2002.

26. Costelli P, Muscaritoli M, Bonetto A, Penna F, Reffo P, Bossola M, Bonelli G, et al. Muscle myostatin signalling is enhanced in experimental cancer cachexia. European journal of clinical investigation 38: 531-538, 2008.

27. Crameri R, Aagaard P, Qvortrup K, Langberg H, Olesen J, and Kjaer M. Myofibre damage in human skeletal muscle: effects of electrical stimulation versus voluntary contraction. The Journal of physiology 583: 365-380, 2007.

28. Crameri R, Langberg H, Magnusson P, Jensen C, Schrøder H, Olesen J, Suetta C, et al. Changes in satellite cells in human skeletal muscle after a single bout of high intensity exercise. The Journal of physiology 558: 333-340, 2004.

29. Decary S, Hamida C, Mouly V, Barbet J, Hentati F, and Butler-Browne G. Shorter telomeres in dystrophic muscle consistent with extensive regeneration in young children. Neuromuscular disorders : NMD 10: 113-120, 2000.

30. Delhaas T, Van der Meer S, Schaart G, Degens H, and Drost M. Steep increase in myonuclear domain size during infancy. Anatomical record (Hoboken, NJ : 2007) 296: 192-197, 2013.

31. Dreyer H, Blanco C, Sattler F, Schroeder E, and Wiswell R. Satellite cell numbers in young and older men 24 hours after eccentric exercise. Muscle Nerve 33: 242-253, 2006.

32. English K, and Paddon-Jones D. Protecting muscle mass and function in older adults during bed rest. Current opinion in clinical nutrition and metabolic care 13: 34-39, 2010.

33. Frontera W, Reid K, Phillips E, Krivickas L, Hughes V, Roubenoff R, and Fielding R. Muscle fiber size and function in elderly humans: a longitudinal study. Journal of applied physiology 105: 637-642, 2008.

34. Fry C, Lee J, Jackson J, Kirby T, Stasko S, Liu H, Dupont-Versteegden E, et al. Regulation of the muscle fiber microenvironment by activated satellite cells during hypertrophy. FASEB journal : official publication of the Federation of American Societies for Experimental Biology 28: 1654-1665, 2014.

35. Gallegly J, Turesky N, Strotman B, Gurley C, Peterson C, and Dupont-Versteegden E. Satellite cell regulation of muscle mass is altered at old age. Journal of applied physiology 97: 1082-1090, 2004.

36. George I, Bish L, Kamalakkannan G, Petrilli C, Oz M, Naka Y, Sweeney H, et al. Myostatin activation in patients with advanced heart failure and after mechanical unloading. European journal of heart failure 12: 444-453, 2010.

37. Gonzalez-Cadavid N, Taylor W, Yarasheski K, Sinha-Hikim I, Ma K, Ezzat S, Shen R, et al. Organization of the human myostatin gene and expression in healthy men and HIV-infected men with muscle wasting. Proceedings of the National Academy of Sciences of the United States of America 95: 14938-14943, 1998.

38. Grobet L, Martin L, Poncelet D, Pirottin D, Brouwers B, Riquet J, Schoeberlein A, et al. A deletion in the bovine myostatin gene causes the double-muscled phenotype in cattle. Nature genetics 17: 71-74, 1997.

39. Gruson D, Ahn S, Ketelslegers J-M, and Rousseau M. Increased plasma myostatin in heart failure. European journal of heart failure 13: 734-736, 2011.

40. Han H, Zhou X, Mitch W, and Goldberg A. Myostatin/activin pathway antagonism: Molecular basis and therapeutic potential. The international journal of biochemistry \& cell biology 45: 2333-2347, 2013. 
41. Hayot M, Rodriguez J, Vernus B, Carnac G, Jean E, Allen D, Goret L, et al. Myostatin up-regulation is associated with the skeletal muscle response to hypoxic stimuli. Molecular and cellular endocrinology 332: 38-47, 2011.

42. Hikida R. In response to Point:Counterpoint: "Satellite cell addition is/is not obligatory for skeletal muscle hypertrophy". Journal of applied physiology (Bethesda, Md : 1985) 103: 1104-1105, 2007.

43. Hvid L, Aagaard P, Justesen L, Bayer M, Andersen J, Ørtenblad N, Kjaer M, et al. Effects of aging on muscle mechanical function and muscle fiber morphology during short-term immobilization and subsequent retraining. Journal of applied physiology 109: 1628-1634, 2010.

44. Hvid L, Ortenblad N, Aagaard P, Kjaer M, and Suetta C. Effects of ageing on single muscle fibre contractile function following short-term immobilisation. The Journal of physiology 589: 4745-4757, 2011.

45. Jameson GS, Von Hoff DD, Weiss GJ, Richards DA, Smith DA, Becerra C, Benson MC, et al. Safety of the antimyostatin monoclonal antibody LY2495655 in healthy subjects and patients with advanced cancer. J Clin Oncol 30 (Suppl) Abstract: 2012.

46. Ju C-R, and Chen R-C. Serum myostatin levels and skeletal muscle wasting in chronic obstructive pulmonary disease. Respiratory medicine 106: 102-108, 2012.

47. Kadi F. In response to Point:Counterpoint: "Satellite cell addition is/is not obligatory for skeletal muscle hypertrophy". Journal of applied physiology 103: 1105, 2007.

48. Kadi F, Schjerling P, Andersen L, Charifi N, Madsen J, Christensen L, and Andersen J. The effects of heavy resistance training and detraining on satellite cells in human skeletal muscles. The Journal of physiology 558: 1005-1012, 2004.

49. Kambadur R, Sharma M, Smith T, and Bass J. Mutations in myostatin (GDF8) in double-muscled Belgian Blue and Piedmontese cattle. Genome research 7: 910-916, 1997.

50. Katz B. The Terminations of the Afferent Nerve Fibre in the Muscle Spindle of the Frog. Philosophical Transactions of the Royal Society B: Biological Sciences 243: 1961.

51. Kim J-s, Cross J, and Bamman M. Impact of resistance loading on myostatin expression and cell cycle regulation in young and older men and women. American journal of physiology Endocrinology and metabolism 288: 9, 2005.

52. Kim J-s, Kosek D, Petrella J, Cross J, and Bamman M. Resting and load-induced levels of myogenic gene transcripts differ between older adults with demonstrable sarcopenia and young men and women. Journal of applied physiology 99: 2149-2158, 2005.

53. Kosek D, Kim J-S, Petrella J, Cross J, and Bamman M. Efficacy of 3 days/wk resistance training on myofiber hypertrophy and myogenic mechanisms in young vs. older adults. Journal of applied physiology 101: 531-544, 2006.

54. Lalani R, Bhasin S, Byhower F, Tarnuzzer R, Grant M, Shen R, Asa S, et al. Myostatin and insulin-like growth factor-I and -II expression in the muscle of rats exposed to the microgravity environment of the NeuroLab space shuttle flight. The Journal of endocrinology 167: 417-428, 2000.

55. Lang C, Silvis C, Nystrom G, and Frost R. Regulation of myostatin by glucocorticoids after thermal injury. FASEB journal : official publication of the Federation of American Societies for Experimental Biology 15: 1807-1809, 2001.

56. Langley B, Thomas M, Bishop A, Sharma M, Gilmour S, and Kambadur R. Myostatin inhibits myoblast differentiation by down-regulating MyoD expression. The Journal of biological chemistry 277: 4983149840, 2002.

57. Larsson L, Sjödin B, and Karlsson J. Histochemical and biochemical changes in human skeletal muscle with age in sedentary males, age 22--65 years. Acta physiologica Scandinavica 103: 31-39, 1978.

58. Lee S-J, Huynh T, Lee Y-S, Sebald S, Wilcox-Adelman S, Iwamori N, Lepper C, et al. Role of satellite cells versus myofibers in muscle hypertrophy induced by inhibition of the myostatin/activin signaling pathway. Proceedings of the National Academy of Sciences of the United States of America 109: 60, 2012.

59. Lee SJ, Huynh TV, Lee YS, Sebald SM, Wilcox-Adelman SA, Iwamori N, Lepper C, et al. Role of satellite cells versus myofibers in muscle hypertrophy induced by inhibition of the myostatin/activin signaling 
pathway. Proceedings of the National Academy of Sciences of the United States of America 109: E23532360, 2012.

60. Leenders M, Verdijk L, van der Hoeven L, van Kranenburg J, Nilwik R, and van Loon L. Elderly men and women benefit equally from prolonged resistance-type exercise training. J Gerontol A Biol Sci Med Sci 68: 769-779, 2013.

61. Leenders M, Verdijk LB, van der Hoeven L, van Kranenburg J, Nilwik R, and van Loon LJ. Elderly men and women benefit equally from prolonged resistance-type exercise training. J Gerontol A Biol Sci Med Sci 68: 769-779, 2013.

62. Lexell J, Taylor C, and Sjöström M. What is the cause of the ageing atrophy? Total number, size and proportion of different fiber types studied in whole vastus lateralis muscle from 15- to 83-year-old men. Journal of the neurological sciences 84: 275-294, 1988.

63. Lowe D. In response to Point:Counterpoint: "Satellite cell addition is/is not obligatory for skeletal muscle hypertrophy". Journal of applied physiology (Bethesda, Md : 1985) 103: 1106, 2007.

64. Luo D, Renault V, and Rando $T$. The regulation of Notch signaling in muscle stem cell activation and postnatal myogenesis. Seminars in cell \& developmental biology 16: 612-622, 2005.

65. Luz M, Marques $\mathrm{M}$, and Santo Neto H. Impaired regeneration of dystrophin-deficient muscle fibers is caused by exhaustion of myogenic cells. Brazilian journal of medical and biological research $=$ Revista brasileira de pesquisas médicas e biológicas / Sociedade Brasileira de Biofísica [et al] 35: 691-695, 2002.

66. Mantilla C, and Sieck G. In response to Point:Counterpoint: "Satellite cell addition is/is not obligatory for skeletal muscle hypertrophy". Journal of applied physiology (Bethesda, Md : 1985) 103: 1104, 2007.

67. Matheny R, Nindl B, and Adamo M. Minireview: Mechano-growth factor: a putative product of IGF-I gene expression involved in tissue repair and regeneration. Endocrinology 151: 865-875, 2010.

68. Mauro A. Satellite cell of skeletal muscle fibers. The Journal of biophysical and biochemical cytology 9 : 493-495, 1961.

69. McCarthy J, and Esser K. Counterpoint: Satellite cell addition is not obligatory for skeletal muscle hypertrophy. Journal of applied physiology (Bethesda, Md : 1985) 103: 1100, 2007.

70. McCarthy JJ, Mula J, Miyazaki M, Erfani R, Garrison K, Farooqui AB, Srikuea R, et al. Effective fiber hypertrophy in satellite cell-depleted skeletal muscle. Development 138: 3657-3666, 2011.

71. McCroskery S, Thomas M, Maxwell L, Sharma M, and Kambadur R. Myostatin negatively regulates satellite cell activation and self-renewal. The Journal of cell biology 162: 1135-1147, 2003.

72. McFarlane C, Hui GZ, Amanda WZ, Lau HY, Lokireddy S, Xiaojia G, Mouly V, et al. Human myostatin negatively regulates human myoblast growth and differentiation. American journal of physiology Cell physiology 301: C195-203, 2011.

73. McKay B, De Lisio M, Johnston A, O'Reilly C, Phillips S, Tarnopolsky M, and Parise G. Association of interleukin- 6 signalling with the muscle stem cell response following muscle-lengthening contractions in humans. PloS one 4: 2009.

74. McKay B, O'Reilly C, Phillips S, Tarnopolsky M, and Parise G. Co-expression of IGF-1 family members with myogenic regulatory factors following acute damaging muscle-lengthening contractions in humans. The Journal of physiology 586: 5549-5560, 2008.

75. McKay B, Ogborn D, Baker J, Toth K, Tarnopolsky M, and Parise G. Elevated SOCS3 and altered IL-6 signaling is associated with age-related human muscle stem cell dysfunction. American journal of physiology Cell physiology 304: 28, 2013.

76. McKay B, Ogborn D, Bellamy L, Tarnopolsky M, and Parise G. Myostatin is associated with age-related human muscle stem cell dysfunction. FASEB journal : official publication of the Federation of American Societies for Experimental Biology 26: 2509-2521, 2012.

77. McPherron A, Lawler A, and Lee S. Regulation of skeletal muscle mass in mice by a new TGF-beta superfamily member. Nature 387: 83-90, 1997.

78. McPherron A, and Lee S-J. Suppression of body fat accumulation in myostatin-deficient mice. The Journal of clinical investigation 109: 595-601, 2002. 
79. Mikkelsen U, Langberg H, Helmark I, Skovgaard D, Andersen L, Kjaer M, and Mackey A. Local NSAID infusion inhibits satellite cell proliferation in human skeletal muscle after eccentric exercise. Journal of applied physiology 107: 1600-1611, 2009.

80. Moss F, and Leblond C. Nature of dividing nuclei in skeletal muscle of growing rats. The Journal of cell biology 44: 459-462, 1970.

81. Murphy K, Cobani V, Ryall J, Ibebunjo C, and Lynch G. Acute antibody-directed myostatin inhibition attenuates disuse muscle atrophy and weakness in mice. Journal of applied physiology 110: 1065-1072, 2011.

82. Murphy K, Koopman R, Naim T, Léger B, Trieu J, Ibebunjo C, and Lynch G. Antibody-directed myostatin inhibition in 21-mo-old mice reveals novel roles for myostatin signaling in skeletal muscle structure and function. FASEB journal : official publication of the Federation of American Societies for Experimental Biology 24: 4433-4442, 2010.

83. Murphy K, Ryall J, Snell S, Nair L, Koopman R, Krasney P, Ibebunjo C, et al. Antibody-directed myostatin inhibition improves diaphragm pathology in young but not adult dystrophic mdx mice. The American journal of pathology 176: 2425-2434, 2010.

84. Murphy KT, Chee A, Gleeson BG, Naim T, Swiderski K, Koopman R, and Lynch GS. Antibody-directed myostatin inhibition enhances muscle mass and function in tumor-bearing mice. AJP: Regulatory, Integrative and Comparative Physiology 301: 2011.

85. Nielsen J, Aagaard P, Bech R, Nygaard T, Hvid L, Wernbom M, Suetta C, et al. Proliferation of myogenic stem cells in human skeletal muscle in response to low-load resistance training with blood flow restriction. The Journal of physiology 590: 4351-4361, 2012.

86. Nilwik R, Snijders T, Leenders M, Groen B, van Kranenburg J, Verdijk L, and van Loon L. The decline in skeletal muscle mass with aging is mainly attributed to a reduction in type II muscle fiber size. Exp Gerontol 48: 492-498, 2013.

87. O'Connor R, and Pavlath G. Point:Counterpoint: Satellite cell addition is/is not obligatory for skeletal muscle hypertrophy. Journal of applied physiology 103: 1099-1100, 2007.

88. O'Connor R, Pavlath G, McCarthy J, and Esser K. Last Word on Point:Counterpoint: Satellite cell addition is/is not obligatory for skeletal muscle hypertrophy. Journal of applied physiology (Bethesda, Md : 1985) 103: 1107, 2007.

89. O'Reilly C, McKay B, Phillips S, Tarnopolsky M, and Parise G. Hepatocyte growth factor (HGF) and the satellite cell response following muscle lengthening contractions in humans. Muscle Nerve 38: 14341442, 2008.

90. Oertel G. Morphometric analysis of normal skeletal muscles in infancy, childhood and adolescence. An autopsy study. Journal of the neurological sciences 88: 303-313, 1988.

91. Otto A, Schmidt C, Luke G, Allen S, Valasek P, Muntoni F, Lawrence-Watt D, et al. Canonical Wnt signalling induces satellite-cell proliferation during adult skeletal muscle regeneration. Journal of cell science 121: 2939-2950, 2008.

92. Oustanina S, Hause G, and Braun T. Pax7 directs postnatal renewal and propagation of myogenic satellite cells but not their specification. The EMBO journal 23: 3430-3439, 2004.

93. Pattison J, Folk L, Madsen R, and Booth F. Selected Contribution: Identification of differentially expressed genes between young and old rat soleus muscle during recovery from immobilization-induced atrophy. Journal of applied physiology 95: 2171-2179, 2003.

94. Petrella J, Kim J-s, Cross J, Kosek D, and Bamman M. Efficacy of myonuclear addition may explain differential myofiber growth among resistance-trained young and older men and women. American journal of physiology Endocrinology and metabolism 291: 46, 2006.

95. Petrella J, Kim J-S, Mayhew D, Cross J, and Bamman M. Potent myofiber hypertrophy during resistance training in humans is associated with satellite cell-mediated myonuclear addition: a cluster analysis. Journal of applied physiology 104: 1736-1742, 2008.

96. Philippou A, Halapas A, Maridaki M, and Koutsilieris M. Type I insulin-like growth factor receptor signaling in skeletal muscle regeneration and hypertrophy. Journal of musculoskeletal \& neuronal interactions 7: 208-218, 2007. 
97. Pistilli E, Bogdanovich S, Goncalves M, Ahima R, Lachey J, Seehra J, and Khurana T. Targeting the activin type IIB receptor to improve muscle mass and function in the $\mathrm{mdx}$ mouse model of Duchenne muscular dystrophy. The American journal of pathology 178: 1287-1297, 2011.

98. Plant P, Brooks D, Faughnan M, Bayley T, Bain J, Singer L, Correa J, et al. Cellular markers of muscle atrophy in chronic obstructive pulmonary disease. American journal of respiratory cell and molecular biology 42: 461-471, 2010.

99. Reardon K, Davis J, Kapsa R, Choong P, and Byrne E. Myostatin, insulin-like growth factor-1, and leukemia inhibitory factor mRNAs are upregulated in chronic human disuse muscle atrophy. Muscle \& nerve 24: 893-899, 2001.

100. Rehfeldt C. In response to Point:Counterpoint: "Satellite cell addition is/is not obligatory for skeletal muscle hypertrophy". Journal of applied physiology (Bethesda, Md : 1985) 103: 1104, 2007.

101. Rosenblatt J, and Parry D. Adaptation of rat extensor digitorum longus muscle to gamma irradiation and overload. Pflügers Archiv : European journal of physiology 423: 255-264, 1993.

102. Rosenblatt J, and Parry D. Gamma irradiation prevents compensatory hypertrophy of overloaded mouse extensor digitorum longus muscle. Journal of applied physiology 73: 2538-2543, 1992.

103. Rosenblatt J, Yong D, and Parry D. Satellite cell activity is required for hypertrophy of overloaded adult rat muscle. Muscle Nerve 17: 608-613, 1994.

104. Roy R, Monke S, Allen D, and Edgerton V. Modulation of myonuclear number in functionally overloaded and exercised rat plantaris fibers. Journal of Applied ... 1999.

105. Sambasivan R, Yao R, Kissenpfennig A, Van Wittenberghe L, Paldi A, Gayraud-Morel B, Guenou H, et al. Pax7-expressing satellite cells are indispensable for adult skeletal muscle regeneration. Development (Cambridge, England) 138: 3647-3656, 2011.

106. Sartori R, Milan G, Patron M, Mammucari C, Blaauw B, Abraham R, and Sandri M. Smad2 and 3 transcription factors control muscle mass in adulthood. American journal of physiology Cell physiology 296: 57, 2009.

107. Scharner J, and Zammit P. The muscle satellite cell at 50: the formative years. Skeletal muscle 1: 28 , 2011.

108. Schiaffino S, Bormioli SP, and Aloisi M. The fate of newly formed satellite cells during compensatory muscle hypertrophy. Virchows Arch B Cell Pathol 21: 113-118, 1976.

109. Schuelke M, Wagner K, Stolz L, Hübner C, Riebel T, Kömen W, Braun T, et al. Myostatin mutation associated with gross muscle hypertrophy in a child. The New England journal of medicine 350: 26822688, 2004.

110. Sinha M, Jang YC, Oh J, Khong D, Wu EY, Manohar R, Miller C, et al. Restoring systemic GDF11 levels reverses age-related dysfunction in mouse skeletal muscle. Science 344: 649-652, 2014.

111. Sousa-Victor P, Gutarra S, Garcia-Prat L, Rodriguez-Ubreva J, Ortet L, Ruiz-Bonilla V, Jardi M, et al. Geriatric muscle stem cells switch reversible quiescence into senescence. Nature 506: 316-321, 2014.

112. Suetta C, Frandsen U, Mackey A, Jensen L, Hvid L, Bayer M, Petersson S, et al. Ageing is associated with diminished muscle re-growth and myogenic precursor cell expansion early after immobility-induced atrophy in human skeletal muscle. The Journal of physiology 591: 3789-3804, 2013.

113. Suetta C, Hvid L, Justesen L, Christensen U, Neergaard K, Simonsen L, Ortenblad N, et al. Effects of aging on human skeletal muscle after immobilization and retraining. Journal of applied physiology 107: 11721180, 2009.

114. Sun D, Chen Y, and Rabkin R. Work-induced changes in skeletal muscle IGF-1 and myostatin gene expression in uremia. Kidney international 70: 453-459, 2006.

115. Tatsumi R, Hattori A, Ikeuchi Y, Anderson J, and Allen R. Release of hepatocyte growth factor from mechanically stretched skeletal muscle satellite cells and role of $\mathrm{pH}$ and nitric oxide. Molecular biology of the cell 13: 2909-2918, 2002.

116. Tatsumi R, Liu X, Pulido A, Morales M, Sakata T, Dial S, Hattori A, et al. Satellite cell activation in stretched skeletal muscle and the role of nitric oxide and hepatocyte growth factor. American journal of physiology Cell physiology 290: 94, 2006. 
117. Taylor WE, Bhasin S, Artaza J, Byhower F, Azam M, Willard DH, Jr., Kull FC, Jr., et al. Myostatin inhibits cell proliferation and protein synthesis in $\mathrm{C} 2 \mathrm{C} 12$ muscle cells. American journal of physiology Endocrinology and metabolism 280: E221-228, 2001.

118. Thomas M, Langley B, Berry C, Sharma M, Kirk S, Bass J, and Kambadur R. Myostatin, a negative regulator of muscle growth, functions by inhibiting myoblast proliferation. The Journal of biological chemistry 275: 40235-40243, 2000.

119. Toth K, McKay B, De Lisio M, Little J, Tarnopolsky M, and Parise G. IL-6 induced STAT3 signalling is associated with the proliferation of human muscle satellite cells following acute muscle damage. PloS one 6: 2011.

120. Vassilopoulos D, Lumb E, and Emery A. Karyometric changes in human muscle with age. European neurology 16: 31-34, 1977.

121. Velleman S, Li X, Coy C, and McFarland D. The effect of fibroblast growth factor 2 on the in vitro expression of syndecan-4 and glypican-1 in turkey satellite cells. Poultry science 87: 1834-1840, 2008.

122. Verdijk L, Dirks M, Snijders T, Prompers J, Beelen M, Jonkers R, Thijssen D, et al. Reduced satellite cell numbers with spinal cord injury and aging in humans. Med Sci Sports Exerc 44: 2322-2330, 2012.

123. Verdijk L, Gleeson B, Jonkers R, Meijer K, Savelberg H, Dendale P, and van Loon L. Skeletal muscle hypertrophy following resistance training is accompanied by a fiber type-specific increase in satellite cell content in elderly men. J Gerontol A Biol Sci Med Sci 64: 332-339, 2009.

124. Verdijk L, Koopman R, Schaart G, Meijer K, Savelberg H, and van Loon L. Satellite cell content is specifically reduced in type II skeletal muscle fibers in the elderly. American journal of physiology Endocrinology and metabolism 292: 7, 2007.

125. Verdijk L, Snijders T, Beelen M, Savelberg H, Meijer K, Kuipers H, and Van Loon L. Characteristics of muscle fiber type are predictive of skeletal muscle mass and strength in elderly men. Journal of the American Geriatrics Society 58: 2069-2075, 2010.

126. Verney J, Kadi F, Charifi N, Féasson L, Saafi M, Castells J, Piehl-Aulin K, et al. Effects of combined lower body endurance and upper body resistance training on the satellite cell pool in elderly subjects. Muscle Nerve 38: 1147-1154, 2008.

127. Wagner K. Muscle regeneration through myostatin inhibition. Current opinion in rheumatology 17: 720724, 2005.

128. Wagner KR, Fleckenstein JL, Amato AA, Barohn RJ, Bushby K, Escolar DM, Flanigan KM, et al. A phase I/IItrial of MYO-029 in adult subjects with muscular dystrophy. Annals of neurology 63: 561-571, 2008.

129. Walker D, Fry C, Drummond M, Dickinson J, Timmerman K, Gundermann D, Jennings K, et al. PAX7+ satellite cells in young and older adults following resistance exercise. Muscle Nerve 46: 51-59, 2012.

130. Wall B, Snijders T, Senden J, Ottenbros C, Gijsen A, Verdijk L, and van Loon L. Disuse impairs the muscle protein synthetic response to protein ingestion in healthy men. J Clin Endocrinol Metab DOI: 10.1210/jc.2013-2098, 2013.

131. Wall B, and van Loon L. Nutritional strategies to attenuate muscle disuse atrophy. Nutrition reviews 71 : 195-208, 2013.

132. Wang $Q$, and McPherron A. Myostatin inhibition induces muscle fibre hypertrophy prior to satellite cell activation. The Journal of physiology 590: 2151-2165, 2012.

133. Yarasheski K, Bhasin S, Sinha-Hikim I, Pak-Loduca J, and Gonzalez-Cadavid N. Serum myostatinimmunoreactive protein is increased in 60-92 year old women and men with muscle wasting. The journal of nutrition, health \& aging 6: 343-348, 2002.

134. Zarzhevsky N, Menashe O, Carmeli E, Stein H, and Reznick A. Capacity for recovery and possible mechanisms in immobilization atrophy of young and old animals. Annals of the New York Academy of Sciences 928: 212-225, 2001.

135. Zhang L, Rajan V, Lin E, Hu Z, Han H, Zhou X, Song Y, et al. Pharmacological inhibition of myostatin suppresses systemic inflammation and muscle atrophy in mice with chronic kidney disease. FASEB journal : official publication of the Federation of American Societies for Experimental Biology 25: 16531663, 2011. 
136. Zhou X, Wang JL, Lu J, Song Y, Kwak KS, Jiao Q, Rosenfeld R, et al. Reversal of cancer cachexia and muscle wasting by ActRIIB antagonism leads to prolonged survival. Cell 142: 531-543, 2010. 
191

Summary 
192 | Summary 
The age-related progressive loss of skeletal muscle mass and function, termed sarcopenia, is associated with physical disabilities, the loss of independence, and an increased risk of developing chronic metabolic disease. Skeletal muscle satellite cells play a key role in the maintenance, regeneration and growth of muscle tissue. Therefore, agerelated changes in satellite cell content and/or function have been suggested to play an important role in the etiology of sarcopenia. In this thesis, we examined the potential regulatory role of satellite cell pool size and function in relation to both acute and more prolonged muscle atrophy and hypertrophy signals in humans.

In Chapter $\mathbf{2}$ of this thesis we determined muscle fiber characteristics in skeletal muscle tissue in a large group of people with ages ranging over the entire life span. We observed a decline in type II muscle fiber size with an increasing age. The type II muscle fiber atrophy with aging is accompanied by a muscle fiber type-specific decline in satellite cell content. However, the age-related reduction in type II muscle fiber size and satellite cell content can be completely reversed following prolonged resistance type exercise training in healthy elderly men. Obviously, the reduced level of physical activity may play an important role in the development of type II muscle fiber atrophy and associated changes in satellite cell content with aging. In Chapter $\mathbf{3}$ we studied the impact of reducing the level of physical activity on muscle fiber size and satellite cell content. Young adults were subjected to 2 weeks of one-legged knee immobilization by means of a full leg cast. Two weeks of single legged knee immobilization resulted in a considerable decline in both type I and type II muscle fiber size but without any changes in satellite and/or myonuclear content. Subsequently, the work in this chapter suggests that a decline in satellite cell content is not a mechanistic prerequisite for disuse induced muscle atrophy.

Apart from satellite cell content, impairments in the satellite cell activation response to anabolic stimuli may also contribute to the development of sarcopenia. Chapter $\mathbf{4}$ and 5 introduce novel immunohistological techniques that were applied to investigate changes in satellite cell activation status in human skeletal muscle biopsy samples. Skeletal muscle satellite cell activation status is shown to change within 9 hours of recovery after exercise. In addition, we report that changes in satellite cell content and/or activation status occur in a muscle fiber type-specific manner during the first $24 \mathrm{~h}$ after a single bout of exercise. These two studies emphasize the importance of analyzing changes in satellite cell activation, proliferation and/or differentiation in a muscle fiber type-specific manner in response to various anabolic stimuli in both health and disease. Subsequently, in Chapter 6 we determined the time-dependent changes in type I and type II muscle fiber satellite cell content and activation status in both healthy young and elderly men in response to a single bout of resistance type exercise. In this study we demonstrate that during post-exercise recovery the increase in satellite cell content is delayed with aging and is accompanied by a blunted satellite cell activation response. This attenuated response may be instrumental in the reduced capacity of senescent 
muscle to respond to prolonged resistance type exercise training.

In a further attempt to unravel the different factors involved in the satellite cell response to an exercise stimulus, we also looked at the potential role of nutrition. It has been well-documented that during post-exercise recovery, dietary protein intake is essential to support the increase in myofibrillar muscle protein synthesis, thereby allowing net muscle protein accretion. On the other hand, for more long-term muscle adaptation, satellite cells are required to provide additional myonuclei to allow muscle fiber hypertrophy. In Chapter 7, we investigated whether dietary protein intake is also prerequisite to allow a proper satellite response during recovery from a single bout of resistance type exercise. Here we show that an acute reduction in protein intake does not affect the increase in satellite cell content but does change the timeline of myostatin expression during $72 \mathrm{~h}$ of post-exercise recovery. We speculate that the altered myostatin response may represent a compensatory response to allow muscle reconditioning to occur when dietary protein becomes available.

Moving forward in the line of a combined exercise and nutritional approach, in Chapter 8 we assessed whether dietary protein ingestion prior to sleep would have a surplus benefit on the increase in skeletal muscle mass and strength following 12 weeks of resistance type exercise training. In a previous study from our lab we have shown that protein ingestion prior to sleep increases muscle protein synthesis rates during postexercise overnight recovery. However, whether these acute changes in muscle protein synthesis also translate to skeletal muscle adaptation to more prolonged resistance type exercise training remained to be established. In agreement with earlier work, progressive resistance type exercise training resulted in an increase in skeletal muscle mass and strength in both the placebo as well as the protein supplemented group of healthy young men. However, the increase in skeletal muscle mass and strength was significantly greater in the protein supplemented group. We concluded that protein ingestion prior to sleep represents an effective dietary strategy to augment skeletal muscle mass and strength gains during prolonged resistance type exercise training in healthy young males.

On the muscle fiber level, the gains in muscle mass and strength in response to the 12 weeks training program were accompanied by both type I and type II muscle fiber hypertrophy. It is generally believed that muscle fiber hypertrophy is initially supported by an increase in myonuclear domain size. However, the existing myonuclei can only support the underlying increase in transcriptional activity to a certain extent. Subsequently, the incorporation of new, satellite cell derived myonuclei may be required to allow more extensive long-term muscle fiber growth, as was also shown in Chapter 2. In Chapter 9, we specifically examined whether an initial (temporary) increase in myonuclear domain size represents a crucial driving force for subsequent myonuclear accretion in response to prolonged resistance type exercise training. Therefore, the change in muscle fiber size, myonuclear domain size, myonuclear and satellite cell content were assessed at different time-points throughout 12 weeks of resistance type exercise 
training. We show that muscle fiber hypertrophy is accompanied by a time-dependent increase in myonuclear and satellite cell content in response to 12 weeks of resistance type exercise training in young men. However, the exercise training induced muscle fiber hypertrophy is not accompanied by any temporary or permanent increase in myonuclear domain size. As such, changes in myonuclear domain size do not seem to be required to elicit myonuclear accretion and support subsequent muscle hypertrophy in healthy young males.

The final chapter addresses the implications of the findings presented in this thesis, and identifies a number of key topics that need to be addressed in future research. This thesis shows that skeletal muscle satellite cells represent an important factor in exercise induced muscle fiber hypertrophy. As such, an impairment in satellite cell function during post-exercise recovery, as observed in healthy elderly men, may be a crucial factor in the development of sarcopenia, and forms a primary target for intervention strategies aimed to counteract sarcopenia and improve muscle mass and function in the elderly. 

Samenvatting 
198

Samenvatting 
Veroudering gaat gepaard met het verlies van spiermassa en spierkracht, ook wel sarcopenie genoemd. Dit leidt tot beperkingen in het dagelijkse leven, verminderde zelfredzaamheid, een verhoogde kans op de ontwikkeling van chronisch metabole ziektes en een afname in de kwaliteit van leven. Spierstamcellen (ook wel satellietcellen genoemd) zijn van essentieel belang voor onderhoud, regeneratie en groei van skeletspierweefsel. Een daling in het aantal satellietcellen en/of in hun functioneren zou mogelijk een belangrijke rol kunnen spelen bij het ontstaan van sarcopenie. In dit proefschrift worden een aantal humane studies beschreven waarin we getracht hebben om verder inzicht te krijgen in de precieze rol van satellietcellen bij het proces van spierverlies en spiergroei.

In Hoofdstuk 2 hebben we skeletspierweefsel geanalyseerd van een grote groep gezonde mensen in de leeftijdscategorie van 0 tot 86 jaar oud. In dit onderzoek laten we zien dat er een duidelijke daling is waar te nemen in de grootte van de type II spiervezels (ook wel atrofie genoemd) naarmate mensen ouder worden. Deze daling in spiervezel grootte gaat gepaard met een daling in het aantal satellietcellen in de type II spiervezels. Aangezien satellietcellen belangrijk zijn voor het onderhoud van skeletspierweefsel, kan de afname van het aantal satellietcellen in de type II spiervezels mogelijk een belangrijke bijdrage leveren aan het ontstaan van sarcopenie. In dit onderzoek laten wij echter ook zien dat het uitvoeren van krachttraining leidt tot een substantiële toename in de grootte van de type II spiervezels en het aantal satellietcellen bij gezonde oudere mannen. Het behouden van een bepaalde mate van fysieke activiteit, met name met hoge intensiteit zoals bij krachttraining, zou dus een belangrijk onderdeel kunnen vormen binnen een interventieprogramma om het verlies van skeletspiermassa tijdens veroudering tegen te gaan. In Hoofdstuk 3 hebben we onderzocht of juist een daling in fysieke activiteit ook invloed heeft op de grootte van de spiervezels en het aantal satellietcellen. In dit onderzoek hebben we bij twaalf gezonde jonge mannen één been ingegipst voor een periode van twee weken. Gedurende deze twee weken zien we een duidelijke verkleining van de spiervezels. Dit ging echter niet gepaard met een verandering in het aantal spiercelkernen en/of satellietcellen. Dit suggereert dat een daling in het aantal satellietcellen niet direct oorzakelijk is bij spiervezelatrofie op korte termijn.

Naast het aantal satellietcellen, zou een verminderde functie van de satellietcel een cruciale rol kunnen spelen in ontwikkeling van sarcopenie op lange termijn. Hoofdstuk 4 en 5 beschrijven nieuwe immunohistologische analyse technieken die zijn toegepast om veranderingen in de activatie status van de satellietcel te kunnen onderzoeken in humaan skeletspierweefsel. We laten zien dat de activatiestatus van de satellietcel verandert binnen negen uur na fysieke inspanning. Daarnaast tonen we aan dat de veranderingen in het aantal satellietcellen en/of activatie status van de satellietcel, spiervezel type specifiek zijn in de eerste 24 uur na een enkele inspanningssessie. Deze resultaten geven aan dat het van essentieel belang is dat de veranderingen in satelliet- 
cel activatie, proliferatie en/of differentiatie in zowel type I als type II spiervezels apart worden geanalyseerd. Met behulp van deze analyse technieken hebben we in Hoofdstuk 6 onderzocht of er verschillen aanwezig zijn in de toename van het aantal- en/of het functioneren van de satellietcellen tussen gezonde jonge en oudere mannen in de eerste dagen na fysieke inspanning. Dit onderzoek laat zien dat de toename in het aantal satellietcellen tijdens herstel na inspanning vertraagd is in gezonde oudere mannen. Deze vertraagde toename in het aantal satellietcellen tijdens de herstel periode gaat gepaard met een verminderde activatie van de satellietcellen. Deze verlaagde satellietcel respons zou een belangrijke oorzaak kunnen zijn voor de verminderde capaciteit van ouderen om een toename in spiermassa en -kracht te realiseren tijdens een krachttrainingsprogramma.

Naast fysieke inspanning vormt voeding een belangrijke anabole prikkel voor ons skeletspierstelsel. Het is eerder aangetoond dat de inname van eiwitten via onze voeding van essentieel belang is om de netto spiereiwitsynthese direct na fysieke inspanning te stimuleren. Om spiervezelgroei op lange termijn te bewerkstelligen is het noodzakelijk dat satellietcellen geactiveerd worden en prolifereren, om extra spiercelkernen te leveren. Het is echter niet bekend in hoeverre eiwitinname ook van invloed is op de satellietcel respons na het uitvoeren van fysieke inspanning. In Hoofdstuk 7 hebben we onderzocht of eiwitinname noodzakelijk is om een normale satellietcel activatie en proliferatie te kunnen bewerkstelligen in de eerste dagen na een enkele krachtinspanningssessie. Wij tonen aan dat eiwitinname geen invloed heeft op de toename in het aantal satellietcellen na fysieke inspanning. We zien daarentegen wel dat de tijdslijn van myostatine expressie veranderd is tijdens de eerste 72 uur van herstel. De veranderde myostatine expressie zou wellicht een compensatie mechanisme kunnen zijn dat de spier in staat stelt om de adaptieve processen alsnog op gang te brengen op het moment dat voldoende eiwit via de voeding voor de spier beschikbaar komt.

Hoewel 'acute studies' zoals in hoofdstuk 4-7 verder mechanistisch inzicht verschaffen in de respons op anabole prikkels, is de vertaling naar lange termijn veranderingen in spiermassa en spierkracht uiteindelijk van essentieel belang. In dat kader hebben we in Hoofdstuk 8 gekeken naar het effect van het dagelijks innemen van een eiwitsupplement voor het slapen gaan op de toename in spiermassa en spierkracht gedurende 12 weken krachttraining in gezonde jonge mannen. Uit een voorgaande studie van onze onderzoeksgroep is gebleken dat het innemen van een eiwitsupplement voor het slapen gaan een positief effect heeft op de spiereiwitsynthese gedurende nachtelijk herstel na een enkele krachtinspanningssessie. Of dit effect op de spiereiwitsynthese gedurende een enkele nacht ook daadwerkelijk tot een grotere toename in spiermassa en/of kracht leidt wanneer dit voor een langere periode zou worden herhaald was echter nog onduidelijk. Na 12 weken krachttraining zagen we een duidelijke toename in spiermassa en spierkracht in zowel de placebo als de eiwit groep. De toename in de dwarsdoorsnede van de bovenbeenspieren en ook de toename in spierkracht waren echter wel significant groter in de eiwit groep in vergelijking met de placebo groep. 
Inname van een eiwitsupplement voor het slapen gaan blijkt dus een effectieve interventie strategie om spiermassa en spierkracht verder te laten toenemen gedurende lange termijn krachttraining in gezonde jonge mannen. De toename in spiermassa na 12 weken krachttraining ging gepaard met een substantiële toename in spiervezel grootte.

Eerder onderzoek gesuggereerd dat een toename in spiervezel grootte aanvankelijk ondersteund wordt door een toename in de grootte van het "spiercelkerndomein"; de theoretische hoeveelheid cytoplasma die door elke spiercelkern wordt ondersteund. De bestaande spiercelkernen kunnen echter deze toename in spiervezel grootte maar tot op een zekere hoogte ondersteunen. Voor verdere groei is het dus noodzakelijk dat nieuwe spiercelkernen worden ingebouwd in de spiercel. In de wetenschap wordt er tot op dit moment vanuit gegaan dat de aanvankelijke toename in de grootte van het spiercelkerndomein de drijvende kracht is om het aantal spiercelkernen te laten toenemen gedurende lange termijn krachttraining. Hoofdstuk 9 beschrijft het onderzoek waarbij voor het eerst is gekeken naar de tijdsafhankelijke veranderingen in de grootte van de spiervezel, het spiercelkerndomein, het aantal spiercelkernen en satellietcellen op verschillende momenten gedurende 12 weken krachttraining. In dit onderzoek laten wij zien dat spiervezelgroei gepaard gaat met een tijdsafhankelijke toename in het aantal spiercelkernen en satellietcellen gedurende 12 weken krachttraining. De toename in spiervezel grootte gaat echter niet gepaard met een permanente of tijdelijke toename in de grootte van het spiercelkerndomein. De conclusie van dit onderzoek luidt dan ook dat een verandering in de grootte van het spiercelkerndomein geen voorwaarde is om het aantal spiercelkernen te laten toenemen en zodoende spiervezelgroei in gezonde jonge mannen te bewerkstelligen.

In het laatste hoofdstuk worden de onderzoeksresultaten nader bediscussieerd en worden specifieke doelen voor toekomstig onderzoek geformuleerd. Dit proefschrift toont aan dat satellietcellen een belangrijk factor zijn om inspanning geïnduceerde spiervezelgroei te bewerkstelligen. Een verminderde satellietcel functie bij ouderen zou een cruciale rol kunnen spelen in de ontwikkeling van sarcopenie. Het vormt daarmee een belangrijk aangrijpingspunt voor toekomstige interventies gericht op het behoud of het verbeteren van spiermassa en spierkracht, en daarmee het gezond ouder worden. 

Valorization 
204 Valorization 
At present, many scientific and societal discussions focus on the public health implications of global aging. This should not be a surprise as demographics show that the world's population aged 60 years and over will triple within 50 years, from 600 million in the year 2000 to more than 2 billion by 2050 (1). Two thirds of the elderly population currently lives in the developed world, and this figure is expected to increase up to $75 \%$. Due to greater longevity, the subpopulation of elderly people aged 80 years and over is presently the fastest growing subpopulation in the developed world (1). In the Netherlands, it has been estimated that in the next 40 years more than $25 \%$ of the population will be 65 years or older (2). Furthermore, life expectancy is predicted to rise over the next few decades by 5 years in men and 3 years in women (CBS: Dec 2008). This means that by the year 2050, life expectancy in the Netherlands will be close to 83 and 86 years in men and women, respectively (2). The quality of life during later stages in life is threatened by the progressive decline in muscle mass and strength, leading to functional impairment and disability. In 2007 more than $20 \%$ of the Dutch population aged 65-74 years suffered from functional impairments (CBS: Dec 2008). In elderly aged 75 years and over, impaired physical function was reported in more than $40 \%$ of the population (CBS: Dec 2008). Such reduced functional performance is accompanied by increased morbidity and a greater need for hospitalization and/or institutionalization. Good health is essential to remain independent and to continue to actively take part in family and community life. Prevention and/or treatment of the progressive loss of muscle mass and function with aging is instrumental for elderly to remain independent and to delay the onset of non-communicable and chronic metabolic diseases, such as heart disease, stroke, cancer, and diabetes.

In line with previous research (3-5), Chapter 2 of this thesis provides further evidence that traditional resistance type exercise training is an effective intervention strategy to reverse the loss of skeletal muscle mass with aging, also known as sarcopenia. Even though there is already a general recognition that even the oldest old ( $85+$ years of age) will improve functional capacity and performance in response to resistance type exercise training, there is still much that can be gained by the implementation of such exercise programs into our society. The assumption that exercise protocols, developed from small short-term intervention studies, are automatically adopted by the general public or specific target populations is fictitious. The translation of experimental studies performed in the lab, to the practical implementation of such exercise programs in daily life is challenging. In order to successfully achieve this transition, a more interdisciplinary approach between exercise physiologists, clinicians and health care professionals should be pursued. There is a great need for studies in which the findings from small experimental studies are translated into larger cohort studies that evaluate the feasibility, applicability and overall efficacy of resistance type exercise training programs in daily life. Nonetheless, research on the basal mechanisms of skeletal muscle atrophy and hypertrophy remains crucial to further improve existing and/or develop novel exercise, nutritional and/or pharmaceutical intervention strategies to combat sarcopenia. 
Though many different factors are known to influence the development of sarcopenia, this thesis provides further evidence on the importance of skeletal muscle stem cells, or satellite cells, in the loss of skeletal muscle mass loss with increasing age. Skeletal muscle satellite cells have been implicated as a key factor in the process of skeletal muscle fiber maintenance, regeneration and/or growth. To study the in vivo changes in skeletal muscle satellite cell number and/or function in response to aging and/or exercise training percutaneous muscle biopsy sampling is required. Subsequently, the muscle biopsy samples are prepared to assess satellite cell number and/or function by means of different analytical techniques, including immunofluorescence microscopy. Traditionally, the number of satellite cells has been considered to be the most important and/or primary parameter to assess the role of these cells in muscle atrophy and/or hypertrophy. Throughout this thesis we have used a novel immunohistological approach to assess the changes in satellite cell content and/or activation status in response to the loss of skeletal muscle mass with aging and/or exercise induced muscle fiber hypertrophy. By combining different cell markers we have shown that it is possible to distinguish satellite cells in different stages of the cell cycle in response to anabolic stimuli. The work presented in this thesis demonstrates that satellite cell function is impaired in healthy elderly when compared with young men. Furthermore, we show that a specific protein (i.e. myostatin) that needs to be inhibited to allow proper satellite cell activation, remains elevated in senescent muscle during recovery from a bout of exercise. This altered response may play an important role in the proposed reduced capacity of senescent muscle to increase mass and strength during more prolonged resistance type exercise training. We speculate that elderly people require a more extensive recovery time between exercise bouts to optimize post-exercise reconditioning and, as such, maximize muscle hypertrophy. Hence, this observation during post-exercise recovery in healthy elderly people may proof to be of key importance in the development of future interventions to more effectively prevent and/or treat sarcopenia and, as such, support healthy aging.

Skeletal muscle tissue is known to be comprised of various muscle fiber types that facilitate the muscle to perform different physical tasks, i.e. from low-intensity, to repeated submaximal, or fast/strong maximal contractions. Consequently, different muscle fiber types are able to exhibit a different muscle adaptive response after exercise. In this thesis we demonstrate that satellite cell content and/or activation status respond in a muscle fiber type specific manner during recovery from exercise. As such, we show that it is of crucial importance to evaluate the changes in satellite cell content and/or activations status in a muscle fiber type specific manner. Furthermore, the application of the immunohistological techniques described in this thesis are indispensable for future research to further elucidate the potential role of satellite cells in the skeletal muscle adaptive response to exercise and/or the loss of muscle mass with aging and/or disease.

The concept that impairments in satellite cell function in response to an anabolic stimu- 
lus may form a key factor in the development of sarcopenia could also be of great interest for industry. Nutritional and/or pharmaceutical companies are always on the quest to develop new products/concepts to support healthy aging. Results from this thesis will assist to direct future research aiming at the development of novel exercise, nutritional and/or pharmaceutical interventions strategies to specifically impact impairments in the pathways regulating satellite cell function in order to combat the loss of skeletal muscle mass with aging. Eventually, this will be of major importance from a societal perspective regarding quality of life of the individual, but also from an economic perspective regarding the enormous health care costs associated with sarcopenia.

Apart from greater insight into the etiology of sarcopenia, the results from this thesis may also be translated to other clinical conditions where progressive skeletal muscle mass loss is commonly observed. Conditions like cancer cachexia, chronic obstructive pulmonary disease (COPD), neuromuscular disease, and heart failure are also characterized by the loss of skeletal muscle mass and strength. Little is known about how satellite cells may also be involved in the regulation of skeletal muscle mass loss in these conditions. The identification of satellite cell function in these patient groups may have important implications for future intervention strategies to limit the detrimental effects of disease related muscle mass loss. In addition, it may contribute to the development of new strategies to optimize recovery from other clinical situations such as (surgery induced) bed rest, or immobilization after a fracture.

Although we should realize that as individual scientists, we are all working on only a small piece of what is a bigger puzzle, this thesis provides important new leads for future research. I believe that within the next decades we may be able to revolutionize our ideas on nutritional and/or exercise interventions to combat the age-related loss of skeletal muscle mass and strength and to better support healthy and active aging. 


\section{REFERENCES}

1. WHO. What are the public health implications of global ageing? http://www.who.int/features /qa/42/en /index.html, 2012. 11-09-2013.

2. CBS) CBvdS. Bevolkingsprognose 2012-2060: Langer leven, Langer werken. http://wwwcbsnl/NR/rdonlyres/DB34C87D-823D-49B4-AE3A3DE66CDCB1A/0/2012bevolkingprognoselangerlevenlangerwerken pdf 11-09-2013: 2012.

3. Leenders M, Verdijk LB, van der Hoeven L, van Kranenburg J, Nilwik R, and van Loon LJ. Elderly Men and Women Benefit Equally From Prolonged Resistance-Type Exercise Training. J Gerontol A Biol Sci Med Sci 68:769-779, 2013.

4. Tieland M, Dirks ML, van der Zwaluw N, Verdijk LB, van de Rest O, de Groot LC, and van Loon LJ. Protein supplementation increases muscle mass gain during prolonged resistance-type exercise training in frail elderly people: a randomized, double-blind, placebo-controlled trial. Journal of the American Medical Directors Association 13: 713-719, 2012.

5. Verdijk LB, Jonkers RA, Gleeson BG, Beelen M, Meijer K, Savelberg HH, Wodzig WK, et al. Protein supplementation before and after exercise does not further augment skeletal muscle hypertrophy after resistance training in elderly men. Am J Clin Nutr 89: 608-616, 2009. 
209

Dankwoord 
210 Dankwoord 
Zoals de meeste wel weten ben ik niet iemand van heel veel woorden. Vandaar dat ik dit dankwoord dan ook kort ga houden.

De complete $M 3$ research groep wil ik graag bedanken voor de ontzettend leuke en dynamische werksfeer. Ik heb altijd met veel plezier binnen de vele verschillende onderzoeksprojecten gewerkt.

Luc, bedankt voor alle mogelijkheden die je mij hebt gegeven. De afgelopen jaren heb je mij klaargestoomd om mijn eigen weg te kunnen en durven vinden in de wetenschappelijke wereld. Zonder jouw begeleiding had ik de stap naar het buitenland nooit met zoveel zelfvertrouwen kunnen maken. Zonder twijfel blijven we elkaar tegenkomen in de komende jaren. Bedankt voor een geweldige tijd in de M3 research groep. Mijn mening over het drinken van koffie blijft echter nog altijd onveranderd.

Lex, ik heb ruim 7 jaar onder jouw dagelijkse begeleiding gewerkt en kan dan ook met een gerust hart zeggen dat ik het vak van "wetenschappelijk onderzoeker" grotendeels van jou heb geleerd. Ik heb al onze discussies over onderzoeksopzetten, resultaten en manuscripten altijd erg op prijs gesteld. Ongetwijfeld blijven onze wegen elkaar kruisen in de toekomst. Dank je wel voor al je steun in de laatste maanden voor mijn vertrek naar Canada.

Gianni Parise, thank you for offering me the opportunity to work as a post-doctoral fellow at McMaster University. Without your patience and support it would not have been possible to fulfil my dream of working abroad in a highly respected lab as yours. I am very much enjoying it so far.

Fred Hartgens en Martijn Poeze, hartelijk dank voor al de back-up die jullie mij de afgelopen jaren hebben gegeven bij de verschillende studies. Tevens mijn dank voor het afnemen van spierbiopten op de meest onmogelijke tijdstippen.

Janneau en Rachel, zonder jullie hulp zou ik nu nog steeds in het donkere microscoop hok hebben gezeten. Dank jullie wel voor al de hulp die jullie mij hebben gegeven bij het analyseren van de spierbiopt samples.

Naomi, your enthusiasm for science remains unparalleled. I am grateful for all the fun times we have had together, at work and during our many runs around Maastricht.

Joan, bedankt voor het opzetten en uitvoeren van de western blot analyse binnen de verschillende studies en al je verhalen over hardlopen en wielrennen. 
Joey (a.k.a. beste stagiaire ever), ik ben je eeuwig dankbaar voor het vele werk dat je hebt verzet binnen de projecten van dit proefschrift. Je vastberadenheid om je eigen weg te vinden in je wetenschappelijke en medische carrière is bewonderingswaardig.

Bart en JW, dank jullie wel voor alle top jaren in Maastricht. We blijven contact houden ook al zijn we inmiddels ieder onze eigen weg gegaan. En Bart, maak je geen zorgen, gewoon stug volhouden! Je zal zien dat jij de volgende bent die zijn proefschrift kan gaan verdedigen.

Ben Wall (a.k.a. Bennie Muur), I really want to thank you for all your great help with the immobilization studies. I don't know what I would have done without you. I have enjoyed all the great discussions we have had over past few years.

Bryon McKay, although we have only met each other once during an ACSM conference, we have worked together on quite a number of projects for my dissertation. Thank you for all you time and effort, I have very much appreciated it.

Alle proefpersonen die hebben deelgenomen aan de onderzoeken voor dit proefschrift wil ik graag bedanken voor hun tijd en inzet. Zonder jullie was dit alles absoluut niet mogelijk geweest.

Hein, Cobie en Guus, bedankt voor alle hulp en steun die jullie mij en Anne hebben gegeven in de afgelopen jaren. Hein, bedankt voor alle hardloopschema's die je voor mij hebt geschreven, hardlopen is de perfecte uitlaatklep geweest tijdens mijn promotietraject.

Lieve zusjes (Karin en Ilze), Robert en Tom en neefje Teun, ik wil jullie graag bedanken voor jullie ongelooflijke enthousiasme en gezelligheid, jullie betekenen allemaal heel veel voor mij.

Lieve $P a$ en $M a$, wie had ooit gedacht dat die verlegen jongen van de mavo een proefschrift zou schrijven? Zonder jullie ondersteuning zou mij dit nooit gelukt zijn. De mogelijkheden die jullie mij hebben gegeven om al mijn dromen waar te maken zal ik nooit vergeten. Onze beslissing om naar Canada te verhuizen was niet gemakkelijk, maar mede door jullie steun durven wij onze ambities na te streven. Pa, jij bent mijn grootste voorbeeld.

Lieve Anne, "promoveren doe je niet alleen". Jij weet precies waar ik het over heb, meer hoef ik denk ik dan ook niet te zeggen. Lieve Niels, papa zal later nog wel een keer aan je uitleggen waar zijn boekje over gaat. 
| 213

Curriculum vitae 
214 | Curriculum vitae 
Tim Snijders was born April 15, 1983 in Eindhoven, the Netherlands. He attended secondary school at the Christiaan Huygens College in Eindhoven and graduated from the MAVO and HAVO in 1999 and 2001, respectively. He then studied Cesar Therapy at the Hogeschool Utrecht where he obtained his diploma in 2004. In the same year, Tim started the Bachelor program in Health Sciences at the Faculty of Health, Medicine and Life Sciences at Maastricht University. After obtaining his Bachelor degree in in 2007, he successfully completed the Master program in Physical Activity and Health in 2008 at the same University.

After graduating, Tim worked as a research assistant and research technician at the Department of Human Movement Sciences at Maastricht University. In 2008 Tim was awarded a Kootstra Talent Fellowship for future PhD-students from the Maastricht University Medical Centre+. This fellowship allowed him to develop novel immunohistological staining methods to assess skeletal muscle stem cell activation status in vivo human skeletal muscle tissue. During this time he was able to gather the necessary pilot data to write a Ph.D.-research proposal under the supervision of Prof. Luc J.C. van Loon and Dr. Lex B. Verdijk. This project entitled: "The role of satellite cells in skeletal muscle fiber hypertrophy of senescent muscle" was granted by the MOVE initiative of the Maastricht University Medical Centre+ in 2008 and resulted in this thesis. Throughout the years that Tim worked at the Department of Human Movement Sciences, he was awarded the Young Investigator Award from the European College of Sport Sciences (ECSS) in 2011 and 2012, the International Student Award, and the Gatorade Sport Science Institute Nutrition Award from the American College of Sport Medicine (ACSM) in 2013. Currently, Tim Snijders works as a post-doctoral fellow at the Department of Kinesiology at McMaster University, Hamilton, Canada. He continues his work in the field of exercise physiology, with a special focus on the identification of different exercise and/or nutritional intervention strategies to further augment skeletal muscle protein synthesis and muscle stem cell function in the aging population. 



\section{Publications}




\section{Published}

Snijders T, Verdijk LB, Smeets JS, McKay BR, Senden JM, Hartgens F, Parise G, Greenhaff $P$, van Loon $L$. The skeletal muscle satellite cell response to a single bout of resistancetype exercise is delayed with aging in men. Age (Dordr). 2014;36(4):9699.

Groen BB, Hamer HM, Snijders T, van Kranenburg J, Frijns D, Vink H, van Loon L. Skeletal muscle capillary density and microvascular function are compromised with aging and type 2 diabetes. J Appl Physiol. 2014 15;116(8):998-1005

Dirks ML, Wall BT, Snijders T, Ottenbros CLP, verdijk LB, van Loon LJ. Neuromuscular electrical stimulation prevents muscle disuse atrophy during leg immobilisation in humans. Acta Physiol (Oxf). 2014;210(3):628-41.

Snijders T, Verdijk LB, McKay BR, Smeets JS, van Kranenburg J, Groen BB, Parise G, Greenhaff $P$, van Loon $\amalg$. Dietary protein intake modulates muscle myostatin expression after a single bout of exercise. J Nutr. 2014;144(2):137-45.

Snijders T, Wall B, Dirks ML, et al. Muscle disuse atrophy is not accompanied by changes in skeletal muscle satellite cell content. Clin Sci (Lond). 2014;126(8):557-66.

Wall BT, Snijders T, Senden JM, Ottenbros CL, Gijsen AP, Verdijk LB, van Loon LJ. Disuse impairs the muscle protein synthetic response to protein ingestion in healthy men. J Clin Endocrinol Metab. 2013;98(12):4872-81

Wall BT, Dirks ML, Snijders T, Senden JM, Dolmans J, van Loon LJ. Substantial skeletal muscle loss occurs during only 5 days of disuse. Acta Physiol (Oxf). 2014;210(3):600-11.

Verdijk LB, Snijders T, Drost M, Delhaas T, Kadi F, van Loon LJ. Satellite cells in human skeletal muscle; from birth to old age. Age (Dordr). 2014;36(2):545-7.

Nilwik R, Snijders T, Leenders M, Groen BB, van Kranenburg J, Verdijk LB, van Loon L. The decline in skeletal muscle mass with aging is mainly attributed to a reduction in type II muscle fiber size. Exp Gerontol. 2013;48(5):492-8.

Cermak NM, Snijders T, McKay BR, Parise G, Verdijk LB, Tarnopolsky MA, Gibala MJ, van Loon LJ. Eccentric exercise increases satellite cell content in type II muscle fibers. Med Sci Sports Exerc. 2013;45(2):230-7. 
Verdijk LB, Dirks ML, Snijders T, Promper JJ, Beelen M, Jonkers RA, Thijssen DH, Hopman MT, van Loon LJ. Reduced satellite cell numbers with spinal cord injury and aging in humans. Med Sci Sports Exerc. 2012;44(12):2322-30.

Wall BT, Dirks ML, Verdijk LB, Snijders T, Hansen D, Vranckx P, Burd NA, Dendale P, van Loon LJ. Neuromuscular electrical stimulation increases muscle protein synthesis in elderly type 2 diabetic men. Am J Physiol Endocrinol Metab. 2012 303(5):E614-23

Snijders T, Verdijk LB, Beelen M, McKay BR, Parise G, Kadi F, van Loon L. A single bout of exercise activates skeletal muscle satellite cells during subsequent overnight recovery. Exp Physiol. 2012;97(6):762-73.

Snijders T, Verdijk LB, Hansen D, Dendale P, van Loon L. Continuous endurance-type exercise training does not modulate satellite cell content in obese type 2 diabetes patients. Muscle Nerve. 2011;43(3):393-401.

Verdijk LB, Snijders T, Beelen M, Savelberg HH, Meijer K, Kuipers H, van Loon LJ. Characteristics of muscle fiber type are predictive of skeletal muscle mass and strength in elderly men. J Am Geriatr Soc. 2010;58(11):2069-75.

Snijders T, Verdijk LB, van Loon LJ. The impact of sarcopenia and exercise training on skeletal muscle satellite cells. Ageing Res Rev. 2009;8(4):328-38.

\section{Submitted for publication}

Snijders T, Res PT, Smeets SJS, van Vliet S, Kranenburg J, Maase K, Kies AK, Verdijk LB, van Loon LJ. Protein ingestion prior to sleep increases muscle mass and strength gains during prolonged resistance type exercise training. Submitted in 2014.

Burd NA, Gorissen SH, van Vliet S, Snijders T, van loon LJ. Milk and beef ingestion result in a similar stimulation of myofibrillar protein synthesis during postexercise recovery in young men. Submitted in 2014.

Wall BT, Dirks ML, Snijders T, Stephens F, Senden JM, Verscheijden M, van Loon JL. Short-term muscle disuse atrophy is not associated with increased intramuscular lipid deposition or a decline in skeletal muscle oxidative capacity in young and older males. Submitted in 2014. 


\section{Prepared for submission}

Snijders T, Smeets JSJ, van Kranenburg J, van Loon L, Verdijk LB. Changes in myonuclear domain size do not precede muscle fiber hypertrophy during prolonged resistance type exercise training in healthy young men.

Snijders T, Kramer I, Smeets JSJ, Verdijk LB, Poeze M, van Loon LJ. Extensive type II muscle fiber atrophy in elderly women undergoing acute hip surgery after a fall-related fracture. 
Financial support for the printing of this dissertation was kindly provided by

Nutricia Research

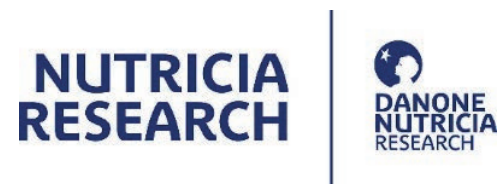

NOC*NSF

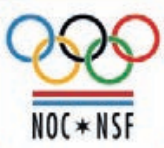


